\title{
PERSPECTIVAS DE INTEGRAÇÃO MODAL RODO-HIDRO-FERROVIÁRIA NA EXPORTAÇÃO \\ DE PRODUTOS AGRÍCOLAS E MINERAIS NO ESTADO DE MATO GROSSO DO SUL
}

\section{Gilmerson Inácio Gonçalves}

\author{
Dissertação apresentada ao Departamento de \\ Transportes da Escola de Engenharia de São \\ Carlos, como parte dos requisitos para \\ obtenção do Título de Mestre em Engenharia \\ Civil - Planejamento e Operação de Sistemas \\ de Transportes.
}

Orientador: Professor Titular João Alexandre Widmer

São Carlos 


\section{Candidato: Tecnólogo GILMERSON INÁCIO GONÇALVES}

Dissertação defendida e julgada em 27/06/2008 perante a Comissão Julgadora:

Prof. Associado JOSÉ EUGÊNIO LEAL

(Pontificia Universidade Católica/PUC/Rio de Janeiro)

Prof. Titular JOÃo ALEXANDRE WIDMER (Orientador)

(Escola de Engenharia de São Carlos/USP)

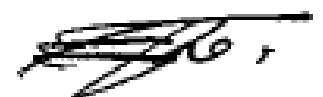

Prof. Dr. MOACIR SCARPELLI

(Universidade Federal de São Carlos/UFSCar)
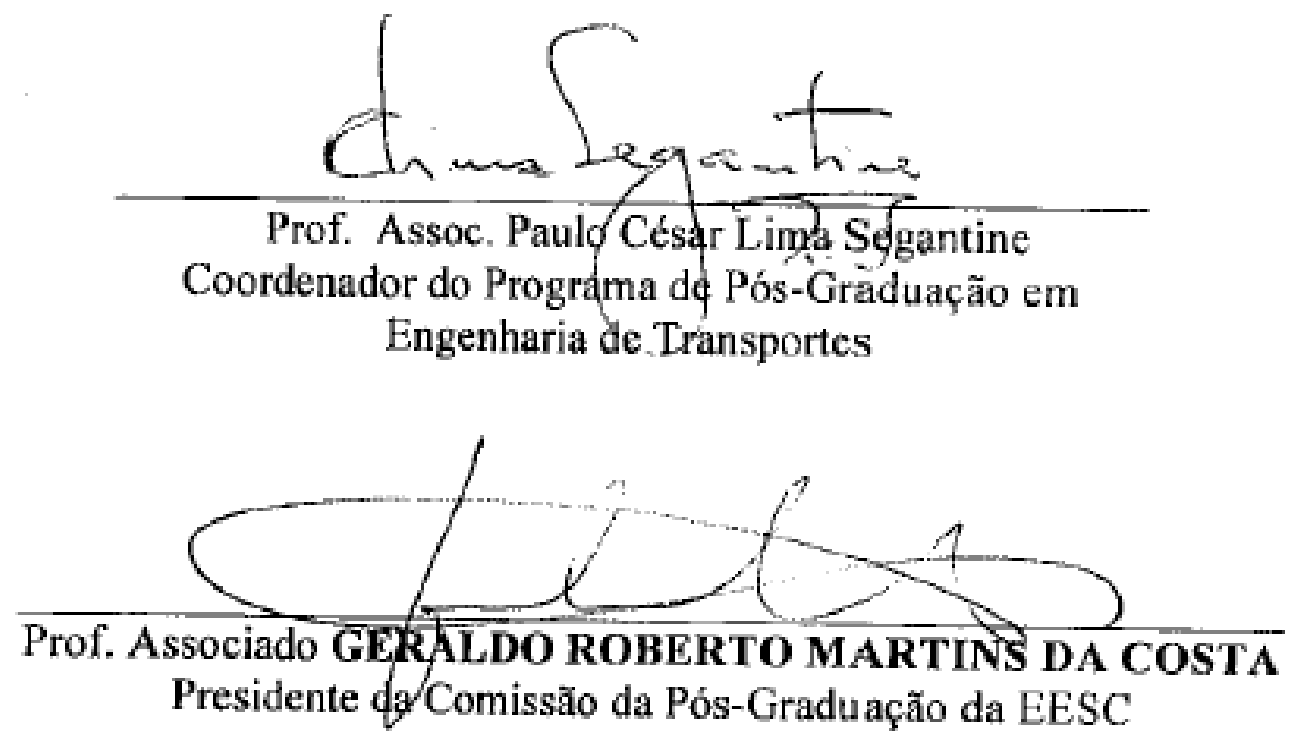

OBS: O PROFESSOR JOSE EUGENIO LEAL PARTICIPOU POR VIDEO CONFERENCIA 


\section{Dedicatória}

Dedico este trabalho aos meus pais, Dalva e Joaquim, pelo eterno incentivo e valores ensinados. 


\section{Agradecimentos}

A Deus, por tudo em minha existência.

A meus pais, irmão e sobrinho, que sempre me apoiaram neste projeto.

Ao Prof. João Alexandre Widmer, pela confiança em mim depositada, orientação e valiosos ensinamentos.

A Ana Paula, pela paciência, apoio, incentivo e dedicação para comigo.

A meus amigos que direta ou indiretamente participaram desta fase de minha vida.

Aos amigos da USP de São Carlos, pela solidariedade e ajuda no desenvolvimento do programa de mestrado.

As empresas Mesquita, Citrosuco e SENAC, as quais pude praticar os meus ensinamentos teóricos.

Aos professores e funcionários do departamento de Transportes da USP.

As empresas AHIPAR, CINCONAV, ADM, ALL, Ferroeste e Wilson Sons pelas informações necessárias a este trabalho.

Aos Professores Rui Botter e Antônio Nelson, pelas sugestões ao projeto. 
"Eu aprendi que para se crescer cama pessaa é precisa me cercar de gente mais inteligente da que eu.

Willian Shakespeare 


\section{Resumo}

GONÇALVES, G. I. (2007). Perspectivas de Integração Modal Rodo-HidroFerroviária na Exportação de Produtos Agrícolas e Minerais no Estado de Mato Grosso do Sul. 2008. 152 p. Dissertação (mestrado). Escola de Engenharia de São Carlos da Universidade de São Paulo, São Carlos, 2008.

O Brasil tem como principal base econômica a exportação de commodities agrícolas e minerais. Esses produtos se caracterizam por possuírem grandes volumes de produção e baixo valor agregado. Diante desses fatos, as economias geradas ao longo da cadeia logística têm papel fundamental para o sucesso da comercialização destes produtos. Nesse contexto, este trabalho teve como objetivo encontrar as rotas de transportes mais econômicas para o escoamento da soja e minérios de ferro e manganês oriundos do estado do Mato Grosso do Sul com destino à exportação. Para tal foram identificados os pólos de geração destas cargas, assim como os modais de transportes existentes e futuros, terminais de transbordos e portos marítimos para exportação. Os métodos utilizados para esta análise foram a geração de cenários, modelos de custo de transporte para os modos rodoviário, ferroviário e fluvial; e sistema de informação geográfica. Os resultados obtidos neste trabalho indicam que opções de rotas com uso do modal hidroviário são as que possuem menores custos, com forte participação da hidrovia Paraguai-Paraná. Sugere-se para futuros trabalhos, a investigação da rede de transporte estudada com o uso de restrições de capacidade e também a inclusão dos custos portuários praticados nos portos marítimos de exportação.

Palavras-Chaves: Transporte intermodal, modelo de custo de transporte, Sistema de Informação Geográfica, construção de cenários. 
GONÇALVES, G. I. (2007). Perspectivas de Integração Modal Rodo-HidroFerroviária na Exportação de Produtos Agrícolas e Minerais no Estado de Mato Grosso do Sul. 2008. 152 p. Dissertation (Master Thesis). São Carlos Engineering School of the University of São Paulo, São Carlos, 2008.

Brazil has as the main economic base the exportation of agricultural and mineral commodities. These products are characterized by having a large quantity of production and low price. Given these facts, the saving generated along the supply chain are fundamental role in the marketing success of these products. In that context, this study aimed to find the most economic transport routes to the disposal of soybeans and iron ore and manganese from the state of Mato Grosso do Sul destined to exportation. For that were identified the places that generate as, and the transportation ways that exist up to now and the future ones, the terminals, transshipments and harbor for export. The methods used for this analysis were the generation of scenarios, models of cost of transport to the modes transport to road, rail and river, and geographic information system. The results obtained in this study indicate that options trades with the use of the waterway are those that have lower costs, with strong participation of the waterway Paraguay-Parana. It is suggested to future researches investigation of the transportation system studied the use of restrictions on capability and the inclusion of costs charged at seaports of exportation.

Key-words: Intermodal Transport, Transport cost model, Geographic Information System, Scenarios building. 


\section{LISTA DE FIGURAS}

Figura 1.1 - Localização do estado de Mato Grosso do Sul 2

Figura 3.1 - Fluxo das etapas do método proposto 15

Figura 4.1 - Rede rodoviária de Mato Grosso do Sul__ 20

Figura 4.2 - Ferrovia Novoeste __ 23

Figura 4.3 - Ferrovia Ferronorte ___ 24

Figura 4.4 - Ferrovia Ferroban ___ 25

Figura 4.5 - ALL Paraná ___ 26

Figura 4.6 - Ferrovia Ferropar _ 27

Figura 4.7 - Hidrovia Paraguai-Paraná _ 29

Figura 4.8 - Hidrovia Tietê-Paraná ___ 31

Figura 5.1 - Pólos de produção de soja em Mato Grosso do Sul ___ 47

Figura 5.2 - Pólo de produção de minérios em Mato Grosso do Sul___ 51

Figura 5.3 - Bitrem de 7 eixos __ 54

Figura 5.4 - Fotos de Comboio tipo "Tietê Duplo" na hidrovia Tietê-Paraná _ 57

Figura 5.5 - Fotos de comboios tipo da hidrovia Paraguai-Paraná ___ 58

Figura 5.6 - Exemplo de uma rede de transporte __ 66

Figura 5.7 - Apresentação dos estados de interesse ___ 72

Figura 5.8 - - Mapa dos pólos produtores de soja e minério de Mato Grosso do Sul_ 74

Figura 5.9 - Mapa dos pontos de embarque, transbordo e entrega final das cargas

Figura 7.1 - Mapa da rota mais econômica para o Pólo de Chapadão do Sul 85

Figura 7.2 - Mapa da rota mais econômica para o Pólo de Campo Grande _ 87

Figura 7.3 - Mapa da segunda rota mais econômica para o Pólo de Campo Grande 88

Figura 7.4 - Mapa da rota mais econômica para o Pólo de Dourados 90

Figura 7.5 - Mapa da rota mais econômica para o Pólo de Corumbá 91

Figura 7.6 - Comparativo com o projeto de prolongamento da Ferropar e os menores custos dos pólos sem o prolongamento 93

Figura 7.7 - Bitrem de 9 eixos. 96

Figura 7.8 - Comparativo dos custos com bitrem de 7 e 9 eixos para os cenários de menor custo de transporte 97 


\section{LISTA DE TABELAS}

Tabela 4.1 - Administração das rodovias em MS 22

Tabela 4.2 - Distâncias da hidrovia do Paraguai 30

Tabela 4.3 - Eclusas da hidrovia Tietê-Paraná 32

Tabela 5.1 - Produção municipal da região Norte no ano de 2000 48

Tabela 5.2 - Produção municipal da região Central no ano de 2000 48

Tabela 5.3 - Produção municipal da região Sul no ano de 2000 49

Tabela 5.4 - Características do comboio Tietê-Paraná adotado para estudo_ 57

Tabela 5.5 - Características do comboio Paraguai-Paraná adotado para estudo

Tabela 5.6 - Fatores operacionais da Ferronorte 58

Tabela 5.7 - Fatores operacionais da Novoeste 61

Tabela 5.8 - Fatores operacionais da Ferroban 62

Tabela 5.9 - Fatores operacionais da ALL - Paraná 62

Tabela 5.10 - Fatores operacionais da Ferropar 62

Tabela 6.1 - Descrição do cenário 1 63

Tabela 6.2 - Descrição do cenário 2 78

Tabela 6.3 - Descrição do cenário 3 78

Tabela 6.4 - Descrição do cenário 4 79

Tabela 6.5 - Descrição do cenário 5 79

Tabela 6.6 - Descrição do cenário 6 80

Tabela 6.7 - Descrição do cenário 7 80

Tabela 6.8 - Descrição do cenário 8 80

Tabela 7.1 - Rotas mais econômicas para o escoamento da região Norte _ 84 Tabela 7.2 - Rotas mais econômicas para o escoamento da região Central _ 86

Tabela 7.3 - Rotas mais econômicas para o escoamento da região Sul ___ 89

Tabela 7.4 - Rotas mais econômicas para o escoamento de minérios___ 91

Tabela 7.5 - Rotas mais econômicas com a ampliação da ferrovia Ferropar_ 93

Tabela 7.6 - Portos marítimos utilizados pelos pólos de produção 95

Tabela 7.7 - Comparativo dos custos com bitrem de 7 e 9 eixos para os cenários de menor custo de transporte. 96 


\section{LISTA DE ABREVIATURAS}

AGITRANS - Agencia de Gestão e Integração de Transportes

AHIPAR - Administração da Hidrovia do Paraguai

AHRANA - Administração da Hidrovia do Paraná

ALL - América Latina Logística

ANP - Administración Nacional de Puertos

ANTAQ - Agência Nacional dos Transportes Aquaviários

ANTF - Agência Nacional dos Transportes Ferroviários

APPA - Administração dos Portos de Paranaguá e Antonina

CEPE - Ciclo de Estudos de Política Estratégicas da ADESG

CINCONAV - Companhia Interamericana de Comercio e Navegação

CNI - Confederação Nacional da Indústria

CODESP - Companhia Docas do Estado de São Paulo

CVCs - Combinação de Veículos de Carga

DNPM - Departamento Nacional de Produção Mineral

ENFE - Ente Nacional de Ferrocarriles

ESALQ - Escola Superior de Agricultura Luiz de Queiros

FIA - Fundação Instituto de Administração

IBGE - Instituto Brasileiro de Geografia e Estatística

ISO - International Organization for Standardization

MRE - Ministério das Relações Exteriores

NTC - Associação Nacional dos Transportadores de Carga

PUERTOSFE - Puerto de Santa Fé

RFFSA - Rede Ferroviária Federal S/A

SEINFRA - Secretaria de Infra-estrutura

SIFRECA - Sistema de Informações de Fretes

SIG - Sistema de Informação Geográfica

TEU - Twenty Equivalent Unit 


\section{SUMÁRIO}

RESUMO vii

ABSTRACT viii

1 INTRODUÇÃO 1

1.1 Objetivos 3

1.2 Justificativa 4

2 REVISÃO BIBLIOGRÁFICA 6

3 MÉTODO 11

4 CARACTERIZAÇÃO DO ESTADO DE MATO GROSSO DO SUL 16

4.1 Pólos de Produção do estado e suas características 16

4.1.1 Pólo de Campo Grande 16

4.1.2 Pólo de Dourados 17

4.1.3 Pólo de Naviraí 17

4.1.4 Pólo de Três Lagoas 17

4.1.5 Pólo de Chapadão do Sul 18

4.1.6 Pólo de Corumbá 18

4.1.7 Pólo de Porto Murtinho 19

4.1.8 Pólo de Jardim 19

4.1.9 Pólo de São Gabriel do Oeste 19

4.1.10 Pólo de Nova Andradina 19

4.2 Sistema Viário Estadual 19

4.2.1 Modal Rodoviário 19

4.2.2 Modal Ferroviário 22

a - Ferrovia Novoeste 22

b - Ferrovia Ferronorte 23

c - Ferrovia Ferroban 24

d - ALL - Paraná 25

e - Ferrovia Ferropar 26

4.2.3 Modal Hidroviário _ـ 27

a - Hidrovia Paraguai-Paraná ___ 27

b - Hidrovia Tietê-Paraná ___ 31

4.3 Sistema portuário que serve o estado de Mato Grosso do Sul 34 
4.3.1 Portos Fluviais 36

a - Hidrovia Tietê-Paraná 36

a.1 - Terminal de Pederneiras (Rio Tietê) __ 36

a.2 - Terminal de Três Lagoas (Rio Paraná - MS)___ 36

a.3 - Porto de São Simão (Rio Paranaíba - GO) __ 36

a.4 - Porto de Bataguassu (Rio Paraná - MS) __ 37

b - Hidrovia Paraguai-Paraná __ 37

b.1 - Porto de Corumbá (MS) __ 37

b.2 - Porto da Sobramil - Corumbá (MS) __ 37

b.3 - Porto de Ladário - Ladário (MS) __ 37

b.4 - Porto da Granel Química - Ladário (MS) ___ 38

b.5 - Porto Gregório Curvo / Porto Esperança - Corumbá (MS) __ 39

b.6 - Porto de Porto Murtinho - Porto Murtinho (MS) ___ 39

4.3.2 Portos Marítimos__ 40

a - Porto de Paranaguá ___ 40

b - Porto de Santos __ 41

c - Porto de Nueva Palmira - Uruguai ___ 43

5 DELIMITAÇÃO DO PROBLEMA __ 45

5.1 Produtos de exportação considerados _ـ 45

5.1 .1 Soja__ 45

a - Região Norte

b - Região Central___ 48

c - Região Sul __ 49

5.1.2 Minério de Ferro e Manganês___ 49

5.2 Composição dos custos de transportes___ 52

5.2.1. Modal rodoviário _ـ 53

5.2.2. Modal hidroviário _ـ 54

1 - Embarcação Tietê-Paraná ___

2 - Embarcação Paraguai-Paraná __ 57

5.2.3. Modal Ferroviário___ 59

a - ALL - América Latina Logística ___ 61

a.1 - Ferronorte _ 61

a.2 - Novoeste__ 62

a.3 - Ferroban 62

a.4 - ALL - Paraná _ 62

b - Ferropar 62

5.2.4. Custos de Transbordos __ 63 
5.3. Escolha da ferramenta de Sistema de informação Geográfica 64

5.3.1. Redes de transportes 65

5.3.2. Problema do Transporte e do Caminho Mínimo 67

5.3.2. Utilização do SIG para Modelo de Rede de Transportes 69

6 MONTAGEM DOS CENÁRIOS 77

6.1 Apresentação dos cenários para o transporte de soja e minério. 77

6.2 Escolha das rotas de transporte 81

6.3 Cálculo da estimativa dos custos de transporte 81

7 ANÁLISE E DISCUSSÃO DOS RESULTADOS 83

7.1 Análise dos resultados para o transporte de soja 83

7.1.1. Região Norte - Pólo de Chapadão do Sul 83

7.1.2. Região Central - Pólo de Campo Grande 86

7.1.3. Região Sul - Pólo de Dourados 88

7.2 Análise dos resultados para o transporte de minérios 90

7.5 Análises considerando o Projeto de ampliação da Ferropar 92

7.4 Análise da atração de cargas dos portos utilizados 94

7.5 Análises de sensibilidade com a utilização do bitrem de nove eixos 95

8 CONCLUSÕES E RECOMENDAÇÕES 98

9 REFERÊNCIAS BIBLIOGRÁFICAS 101

APÊNDICE A - Custos do bitrem de 7 eixos 111

APÊNDICE B - Custos do comboio Tietê-Paraná 115

APÊNDICE C - Custos do comboio Paraguai-Paraná 116

APÊNDICE D - Custos para o Pólo de Chapadão do Sul com bitrem de 7 eixos 117

APÊNDICE E - Custos para o Pólo de Campo Grande com bitrem de 7 eixos 120

APÊNDICE F - Custos para o Pólo de Dourados com bitrem de 7 eixos 123 APÊNDICE G - Custos para o Pólo de Corumbá com o bitrem de 7 eixos 126 APÊNDICE H - Custos do bitrem de 9 eixos 128

APÊNDICE I - Custos para o Pólo de Chapadão do Sul com bitrem de 9 eixos 132

APÊNDICE J - Custos para o Pólo de Campo Grande com bitrem de 9 eixos 135 APÊNDICE K - Custos para o Pólo de Dourados com bitrem de 9 eixos 138 APÊNDICE L - Custos para o Pólo de Corumbá com bitrem de 9 eixos 141 


\section{INTRODUÇÃO}

Em um país com dimensões continentais como o Brasil, a economia gerada pela cadeia logística tem um papel fundamental para o sucesso da comercialização de commodities agrícolas e minerais. Deficiências nas estruturas atuais de transporte, somadas a custos portuários elevados geram um conjunto de fatores altamente desfavoráveis para a competitividade dos produtos nacionais.

Estudos indicam que os custos portuários no Brasil são cerca de $27 \%$ superiores aos da Argentina e Uruguai, isto sem incluir custos gerados por atrasos em embarque (críticos em época de safra), dificuldades burocráticas e as conseqüentes incertezas geradas ao planejamento de exportadores e importadores (FUNDAÇÃOFIA, 2006). Dados da Confederação Nacional da Indústria demonstram que o custo médio de movimentação de um contêiner de 40 pés atinge US\$ 600 no Porto de Santos e US\$ 300 no Porto de Paranaguá, contra US\$120 em Rotterdam (CNI, 2006).

Além disso, no Brasil, a maior parte da movimentação de cargas é realizada por rodovias - cerca de 60\%, contra menos de $40 \%$ nos Estados Unidos e Austrália e de $20 \%$ na China - justamente o modal de transporte de maior custo especialmente para distâncias mais longas. Tal cenário é agravado pelo mal estado de conservação das estradas brasileiras, pela obsolescência da frota de caminhões e pelo congestionamento nas rotas para os portos no período de safra (FUNDAÇÃOFIA, 2006).

Com tais condições, o país não poderá manter um crescimento econômico sustentado, a menos que expanda o volume e melhore a qualidade dos investimentos em infra-estrutura e mais, os investimentos que inicialmente devem ser voltados à eliminação de gargalos de maior impacto imediato, 
posteriormente devem ser orientados segundo uma lógica de prioridades mais elaborada.

Incluído nessa realidade está o estado de Mato Grosso do Sul, ilustrado na Figura 1.1, que tem em sua base econômica a agropecuária. Na produção agrícola, destacam-se como principais produtos a soja, o arroz, o algodão, a cana de açúcar, o trigo, o milho e a mandioca e, na pecuária, o destaque fica para o rebanho bovino de corte, $1^{\circ}$ no ranking nacional com 21,6 milhões de cabeças (SEINFRA, 2006).

Outro grande destaque econômico é para os recursos minerais existentes nas regiões oeste e sudoeste, especialmente nos municípios de Corumbá e de Bodoquena.

Com um total de 77 municípios, sua população total estimada é de 2,3 milhões de habitantes (2005). Distribuído tal contingente por seu território de 357 milhões de $\mathrm{km}^{2}$ resulta em densidade demográfica de 6,34 hab/ $\mathrm{km}^{2}$. O Mato Grosso do Sul se caracteriza como um estado urbano, uma vez que 83,2\% da sua população estão radicadas em cidades. Destas, as principais Campo Grande (sua capital), Dourados, Corumbá, Três Lagoas, Ponta Porã e Aquidauana concentram 53,6\% da população total do Estado (IBGE, 2006).

A extensão territorial de 357 milhões de $\mathrm{km}^{2}$ representa 4,19\% do território brasileiro, sendo $24 \%$ da sua área constituída pelo Pantanal.

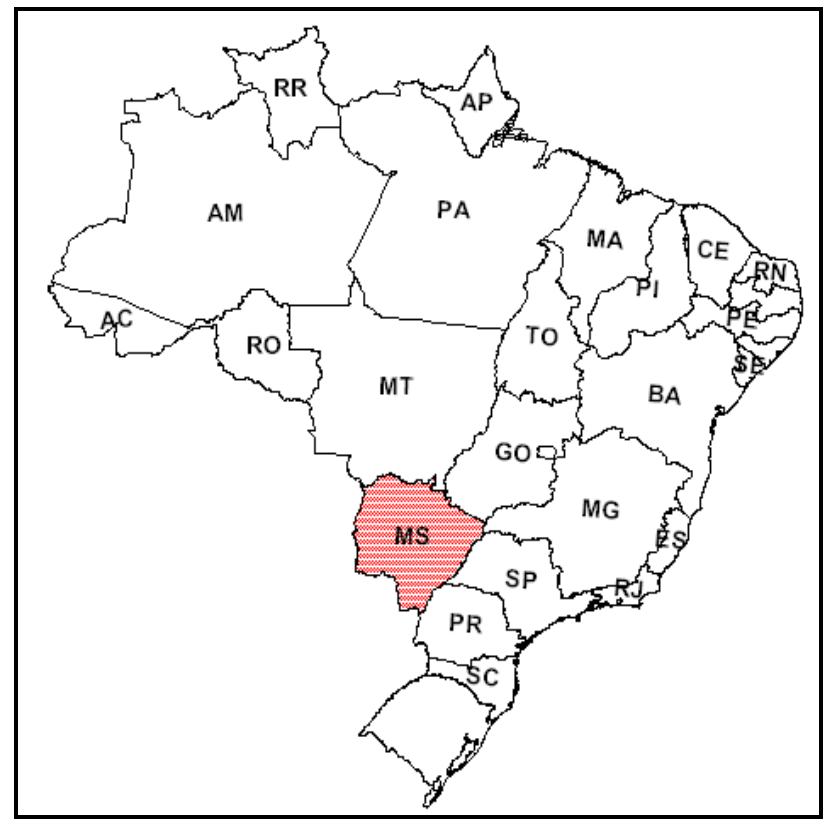

Figura 1.1 - Localização do estado de Mato Grosso do Sul Fonte: Elaborado pelo autor 
De acordo com DUGONJíc (1989), a consolidação do processo de desenvolvimento requer investimentos diversificados e coordenados entre os modais de transporte, para viabilizar a desejável expansão espacial da economia regional.

Considerando as previsões de crescimento da produção e conseqüente comercialização, o sistema de transportes da região terá que facilitar o desenvolvimento destas atividades, de forma a dar-lhe sustentação e competitividade. SOUZA (2002), afirma que os gastos públicos em infraestrutura estão entre os principais fatores explicativos da localização da indústria brasileira nos anos 1970 e 1980, à frente de outros indicadores convencionais, tais como potencial de mercado, subsídios e níveis educacionais. CASTRO (2004) elaborou parâmetros de acessibilidade, encontrando diferenciais significativos entre as regiões.

Nessa vertente, se faz necessária a geração de rotas futuras de exportação focada nos granéis agrícolas (principalmente soja) e nos minérios de ferro e manganês, buscando combinar os modais rodoviário, ferroviário e hidroviário, com o objetivo de proporcionar redução no custo total de transporte.

\subsection{OBJETIVOS}

O objetivo principal deste trabalho é investigar as principais alternativas existentes e futuras para o transporte de soja e minérios de ferro e manganês para exportação oriundas do estado de Mato Grosso do Sul, além de fornecer informações que orientem os órgãos e entidades envolvidas neste mercado.

Para tal, serão realizados os seguintes estudos:

- Descrever as opções existentes para escoamento da produção de soja, minério de ferro e manganês, por meio do transporte multimodal por rodovias, ferrovias e hidrovias;

- Apresentar cada um dos pólos de produção desses produtos, descrevendo suas características e os modais disponíveis para escoamento;

- Gerar as opções de escoamento da produção dos pólos, apresentando uma análise econômica de cada via multimodal; 
- Utilizar um sistema de informação geográfica, que represente o sistema multimodal de transporte para escoamento da soja, minério de ferro e manganês produzidos no Mato Grosso do Sul, com destino à exportação.

- Construir cenários com alternativas de escoamento da produção agrícola e mineral dos pólos estudados de forma a orientar políticas de investimentos em infra-estrutura de transportes para o estado de Mato Grosso do Sul.

\subsection{JUSTIFICATIVA}

Dentre os diversos fatores que motivaram o desenvolvimento desta pesquisa, destacam-se:

- O alto custo da atividade de transporte dentro da cadeia logística, uma vez que essa atividade está classificada, segundo BALLOU (1993), como uma atividade primária, ou seja, de alto custo.

- A importância da produção de soja e da extração de minério de ferro e manganês para a economia do estado do Mato Grosso do Sul.

- A viabilidade econômica da implantação do pólo mínero-siderúrgico de Corumbá, que reside no fato de que as reservas do maciço de Urucum são constituídas de mineral de excelente qualidade. Enquanto que no resto do país as reservas são de $75 \%$ de minério fino e $25 \%$ granulado, em Corumbá dois terços do minério são de classificação granulada.

- O crescimento da produção e implantação de novos pólos gerou automaticamente, inclusive por parte do governo do estado, a necessidade de estudos logísticos de vias multimodais para viabilizar plenamente o escoamento da produção.

- Necessidade de mudança na matriz de transportes do estado, buscando utilizar modais mais baratos, assim como o aumento do uso da intermodalidade e conseqüente implantação de terminais para a operacionalização do sistema multimodal.

- Escassez de trabalhos ligados a utilização logística da hidrovia ParaguaiParaná. 
Neste caso, a proposta de se trabalhar com produtos do complexo soja e minério justifica-se tanto pelo fato da comprovada aptidão e oferta dos produtos na região em estudo, quanto pela viabilidade de elaboração de cenários, uma vez que os mercados produzem prognósticos bastante razoáveis em termos de detalhamento de dados e do desempenho na validação, como pela expansão dos mercados. Além disso, as cargas são bastante expressivas nos volumes movimentados na logística brasileira. 


\section{REVISÃO BIBLIOGRÁFICA}

"A criação e manutenção de obras públicas - tais como boas estradas, pontes, canais navegáveis, portos, ferrovias, etc. - são vetores importantes para o crescimento comercial e social de qualquer região, assim como o aumento da produção e conseqüente riqueza de um estado estão diretamente relacionados às condições e custos de seus transportes até os pontos consumidores" (SMITH, 1988).

Com aproximadamente 1.500 km de "costa" para os rios Paraguai e Paraná, que dão acesso ao Oceano Atlântico e aos mercados consumidores do centrosul, o estado de Mato Grosso do Sul possui um grande potencial para a multimodalidade (SELTRA, 2006). A existência de duas ferrovias, sendo uma interligando estes dois rios rumo ao porto de Santos e ao mercado consumidor paulista e outra fazendo escoar a produção da região norte ao porto de Santos, consolidam essa vocação. Por outro lado, as rodovias existentes determinam corredores importantes que interligados às ferrovias e hidrovias constituirão um sistema integrado de transportes de grande relevância.

Estes corredores já estão, portanto, bem definidos, necessitando apenas de ajustes para se consolidarem definitivamente como opção real para o escoamento das cargas do estado. Os corredores rodoviários necessitam de medidas de curto prazo, suficientes para corrigir as distorções das rodovias constituintes dos corredores de carga do estado, dando-Ihes plenas condições de tráfego.

A escassez de recursos faz com que os investimentos sejam direcionados para obras mais urgentes. Desta forma, o estudo das perspectivas de multimodalidade vem ao encontro da necessidade de crescimento e 
competitividade da produção do estado e da região centro-oeste. Trabalhos com este perfil já foram desenvolvidos por outros autores.

SANT'ANNA (1998) caracterizou e estudou a rede básica de transportes da Amazônia, onde identificou os pólos geradores de carga com um diagnóstico da infra-estrutura de transporte e da economia regional, mostrando também as rotas usadas e suas dificuldades na movimentação destas cargas. A partir desta investigação, o autor estabeleceu critérios para o estudo das alternativas de Origem/Destino da rede, demonstrando as principais características destas ligações tanto para os pólos de atração nacional como para os portos de exportação. Desta forma, foram propostas ações de curto, médio e longo prazo para tornar a rede de transporte da Amazônia competitiva e funcional.

FAJARDO (2001) utilizou um Sistema de Informações Geográficas (SIG) para montar uma rede de transporte que caracterizasse o escoamento da soja nos estados do Pará e de Mato Grosso. Para isso, a autora apresentou em seu trabalho toda a rede de transporte, os pólos de produção e de atração de carga, montando assim, uma rede multimodal para o escoamento da soja produzida nestes estados. O estudo apresenta uma análise da situação atual através dos dados gerados por um SIG (Transcad), e também uma perspectiva de situação futura através da análise de sensibilidade na mudança dos custos dos modais de transportes, o que em muitos pólos geradores veio a alterar as rotas de escoamento.

TIAGO (2002) em sua investigação do problema de localização estratégica de terminais intermodais rodo-ferroviários para contêineres no Estado de São Paulo, utilizando uma matriz O/D de contêineres movimentados concluiu que, para as regiões num raio de $200 \mathrm{~km}$ do porto de Santos, a implantação de terminais intermodais rodo ferroviários só se viabilizaria para condições muito particulares de acesso ao modal ferroviário.

RORATO (2003) investigou alternativas de transporte de cargas frigoríficas entre fábricas e centros de distribuição através do transporte intermodal rodohidroviário de contêineres ISO e do uso de Combinações de Veículo de Carga (CVCs) com PBTC de até 74 toneladas. Com o auxílio de um SIG (Transcad), dimensionou a frota e elaborou um modelo de custos de transporte na rede de rotas para diversos cenários alternativos. Conclui que a utilização do veículo 
rodoviário porta contêineres combinado do tipo bitrem de 9 eixos (3S3B3) apresenta vantagens econômicas em relação ao baú frigorífico nas ligações das pontas dos modais rodoviários e hidroviários. Também através dos resultados gerados, concluiu que o baú frigorífico com capacidade para 40 paletes oferece, na maioria das rotas estudadas, uma alternativa mais competitiva que a integração rodo-hidroviária.

SILVA (2005) analisou uma rede de transporte para a movimentação de açúcar com origem em usinas no interior do Estado de São Paulo para o Porto de Santos. No trabalho são apresentados três cenários distintos de combinação intermodal rodo-ferroviária para o transporte do açúcar. Através dos resultados obtidos, concluiu que o transporte rodoviário realizado por frota de terceiros leva uma vantagem sobre o uso de frota própria e que o sistema rodoferroviário é mais atraente do que o rodoviário porta-a-porta realizado por frota de terceiros em algumas das rotas estudadas.

SOUTHWORTH \& PETERSON (2000) criaram para o governo americano uma rede internacional e multimodal de transportes, com o objetivo de simular diversos pontos de origem e destino, além de suas possíveis conexões multimodais. Através da criação desta rede se obteve um total de 133 mil arcos os quais englobavam rodovias, ferrovias, hidrovias e navegação intercontinental.

CHANG (2007) analisou uma rede de transporte multimodal internacional, através da aplicação de um modelo matemático que processasse simultaneamente três necessidades básicas das rotas estudadas (múltiplos objetivos, modo de agendamento do transporte, tempo de entrega necessário e economia de escala no transporte). O autor sugere que para uma rede de transporte de larga escala a rede seja avaliada através de exemplos de rede de transporte de pequena escala, pois assim as três necessidades básicas são melhor avaliadas para efeito de atendimento da rede e com menor custo de transporte.

ÜLENGIN et al. (2006) construíram um modelo denominado Decisão de Políticas de Transportes, o qual utiliza variáveis que influem na rede multimodal de transporte de pessoas e cargas da Turquia. Através de modelos econométricos, redes neurais artificiais e análise de especialistas no assunto 
foram construídos cenários de relacionamento dos modais utilizados. Como resultado dos cenários analisados o trabalho indica um maior investimento em ferrovias e linhas marítimas que integram o país em nível federal e internacional, porém observando o plano macro da rede multimodal de transporte da Turquia que foi desenvolvida pelo trabalho.

Com o objetivo de determinar as prioridades de investimentos na melhoria e construção da estrutura de transporte intermunicipal, LOUREIRO (1994) construiu um modelo de planejamento de rede multimodal de transporte. Este modelo é baseado em investimentos que promovam um sistema de transporte que minimizem seus custos, além de buscar modos de transportes que gerem menos impactos ao meio ambiente. Este modelo foi testado em uma pequena rede multimodal com resultados satisfatórios para a solução do problema.

KASTURIA (1995) analisou a competição multimodal de transporte na Alemanha, através da avaliação de valores de frete entre rodovia e ferrovia. $O$ autor desenvolve um modelo econométrico baseado num modelo empírico de técnicas de organização industrial, testando este modelo desenvolvido na avaliação da competição entre rodovia e ferrovia tanto para o transporte de carga como para o de passageiro. Os resultados demonstraram que o custo para o transporte de automóveis na Alemanha se encontra próximo do custo marginal.

Em seu trabalho de investigação sobre os custos do transporte da soja brasileira, AFONSO (2006) recomenda o investimento e uso da multimodalidade como gerador de economia na cadeia de transporte.

Como se observa o estudo sobre a competição multimodal de transporte é fartamente encontrado na literatura científica brasileira e estrangeira. Trabalhos realizados por COSTA (1979), MASSELLA (1979), MESQUITA (1980) e KOMAROVA (2000) também são exemplos da importância que é dada para o estudo da competitividade dos fretes e custos entre ferrovias, rodovias e hidrovias.

Outro fato importante nos trabalhos estudados é o uso de ferramentas computacionais e aplicação de modelos matemáticos de otimização, os quais demonstram a preocupação e importância desses estudos com a redução dos custos de transportes e melhor utilização dos modais e seus processos. 
Fatos como os apresentados nesse capítulo e a grande evolução vivida pelo setor de logística, principalmente na etapa de transporte, constituem a base e justificam a continuidade de estudo da multimodalidade de transporte. 


\section{MÉTODO}

O método de pesquisa utilizado neste trabalho é o de geração de cenários. Os cenários, por definição, podem descrever estratégias com várias possibilidades futuras e não prever o futuro. Essa técnica vem sendo muito usada por governos, empresas e militares como ferramenta de análise para auxiliar na tomada de decisão diante de incertezas (MIETZNER e REGER, 2004).

O primeiro conceito de planejamento de cenários surgiu durante a II Guerra Mundial para auxiliar no planejamento militar. A importância dos cenários está na capacidade de unir elementos complexos e compor um conjunto de fatos que são coerentes, sistemáticos, compreensíveis e plausíveis (MIETZNER e REGER, 2004).

$\mathrm{Na}$ teoria, cenários são sínteses de diferentes comportamentos padrões (eventos e estratégias) que guiam para possibilidades futuras. Na prática, os cenários muitas vezes apenas descrevem um conjunto particular de eventos e suas variáveis (ROUBELAT, 2000).

Alguns autores diferenciam planejamento de cenários e construção de cenários. Para esses autores a construção de cenários significa basicamente especular sobre incertezas a respeito do futuro. Conforme SCHWARTZ (2000): "criar memórias do futuro". Nesse contexto, construção de cenários é a base para o planejamento de cenários, ou seja, construção de cenários é uma técnica de gerenciamento usada por tomadores de decisão para articular seus modelos mentais sobre o futuro e, por meio deles, tomar decisões (MARTELLI, 2001).

Os objetivos dessa técnica, segundo FAHEY E RANDEL (1998), são: 
$\checkmark$ Aumentar o entendimento de determinadas situações, pois ajuda a perceber possibilidades futuras e verificar como e por que elas ocorrerão;

$\checkmark$ Produzir novas decisões a partir dos cenários construídos;

$\checkmark$ Redefinir decisões já tomadas, devido a um novo contexto exposto para a tomada de decisão;

$\checkmark$ Identificar decisões secundárias devido a situações marginais que podem ocorrer se determinada decisão for tomada.

Seguindo a classificação proposta por FAHEY e RANDEL (1998), os cenários construídos nesta pesquisa são classificados como Cenários Globais (Global Scenarios). Estes por definição são cenários que oferecem respostas para diferentes ambientes futuros. Cada um dos ambientes tem diferentes opções de análises, implicações em termos de investimentos de longo prazo e decisões operacionais a serem tomadas.

A palavra "cenário" para RINGLAND (2002) pode ser utilizada de muitas formas. Cenários militares, por exemplo, são planos detalhados de contingência para uma série de eventualidades. Os cenários são possíveis visões do mundo que proporcionam um contexto no qual as decisões podem ser tomadas. Cenários não predizem o futuro, mas podem chamar a atenção para um conjunto de mudanças e contextos, permitindo o entendimento e controle da situação. O mesmo autor afirma que, se bem escolhidos pela organização, irão apontar para "mundos" com diferentes respostas para as questões significativas daquela organização. Eles proporcionarão uma visão à frente para decisões de investimentos, inteligência de mercado, novos produtos e mercados, etc.

Para PORTER (1988), cenários são utilizados em estratégias e consistem em visões sobre o que o futuro pode vir a ser. Não é uma previsão, mas sim, um possível futuro que virá. O mesmo autor sugere que as organizações considerem em seus mercados as forças como uma base para o planejamento. Considera ainda que os cenários são ferramentas importantes para o entendimento e busca por novas tendências e recomenda a construção de cenários alternativos como uma forma sensível de análise. 
WACK (1985) considera que a essência de um cenário reside na busca por mudanças de conceitos ou modelos pré-determinados, tornando possível antecipar e preparar-se para o futuro. Devem ser enfatizadas na criação dos cenários a coerência e credibilidade do conjunto de possibilidades existentes para o futuro.

Para SCHWARTZ (2000) cenários não são previsões. O autor defende que não é possível prever o futuro com um razoável grau de certeza. Ao invés disso, continua o autor, os cenários são veículos que ajudam as pessoas a aprender. Ao contrário da previsão tradicional de negócios, ou da pesquisa de mercado, os cenários apresentam imagens alternativas do futuro. Eles não extrapolam simplesmente as tendências presentes.

Somando-se outras perspectivas, como em AAKER (2001), tem-se que os cenários proporcionam uma forma de trabalhar com ambientes complexos, nos quais muitas tendências e eventos relevantes interagem e se afetam mutuamente. Para AAKER (2001) quando as micro tendências e eventos são agregados em um, dois ou três cenários de um ambiente futuro, a análise é mais administrável. Para o autor os cenários não estão focados no esforço de obter informações para a redução de incertezas. Ao contrário, se aceita a possibilidade como opção à certeza de um cenário. O estrategista pode lidar com uma realidade que poderia não vir a acontecer.

Como exemplo de aplicação, a técnica de planejamento de cenários foi utilizada por Pierre Wack, da Royal Dutch / SHELL, no início dos anos 70 . O trabalho de Wack, baseado na tese de desenvolvimentos de cenários do futurista Herman Kahn, ajudou a Shell na crise do petróleo daquela época (LITTLE, 2002).

A Boeing também recorre a cenários de tráfego aéreo em seu planejamento estratégico. A Daimler-Benz Aerospace, concorrente da Boeing, igualmente desenvolveu cenários relativos à revolução do tráfego aéreo global que se estendem até 2.015, bem como cenários regionais para a Europa, América do Norte e Ásia. Nestes, esta organização considerou diferentes regiões, determinando oportunidades e riscos nos vários mercados (PRESCOTT \& MILLER, 2002). 
Recentemente, TEIXEIRA (2007), utilizou a técnica de construção de cenários para avaliar opções de transporte intermodal, econômica e operacionalmente mais atraentes que as praticadas hoje no transporte de carga geral fracionada em conexões com a região amazônica. Os resultados obtidos indicaram que opções de rotas rodo-marítimas e rodo-fluviais apresentam significativas reduções no custo total de transporte com relação às rotas preferenciais, hoje praticadas para as ligações entre Belém-São Paulo e Manaus-São Paulo. Os resultados mostraram, também, não haver perspectivas para o transporte rodoferroviário e rodo-fluvial-ferroviário nessas ligações, uma vez que, neste caso, o custo obtido é maior que os das rotas hoje praticadas. Em outra análise, KATO (2005) constrói cenários para o planejamento da indústria de transporte rodoviário de cargas no Brasil. MORAES (2003) realiza uma análise das perspectivas de operação ferroviária na Baixada Santista, através da simulação de cinco cenários de operação.

Para o estudo de ampliação do canal do Panamá, foi construído um modelo que simulou através de cenários os níveis de atendimento dos serviços para diversas condições de operações e investimentos na infra-estrutura do canal (TECNOLOGÍSTICA, 2007).

Por fim citam-se também como exemplos para o uso dos cenários no planejamento do transporte, NIJKAMP et al. (1998), NIJKAMP e BLAAS (1994), MASSER et al. (1992, 1993) e STEAD e BANISTER (1999).

Os cenários construídos neste trabalho partiram de uma coleção de informações relacionadas com o problema estudado.

Essas informações foram coletadas em órgãos e instituições competentes ou por pesquisas diretas em campo.

O esquema representado na Figura 3.1 demonstra as etapas do método proposto no presente trabalho. Os resultados obtidos com o método são gerados com auxílio de um Sistema de Informação Geográfica específico para área de transportes e planilhas eletrônicas. O programa utilizado é o Transcad, versão 3.6. 


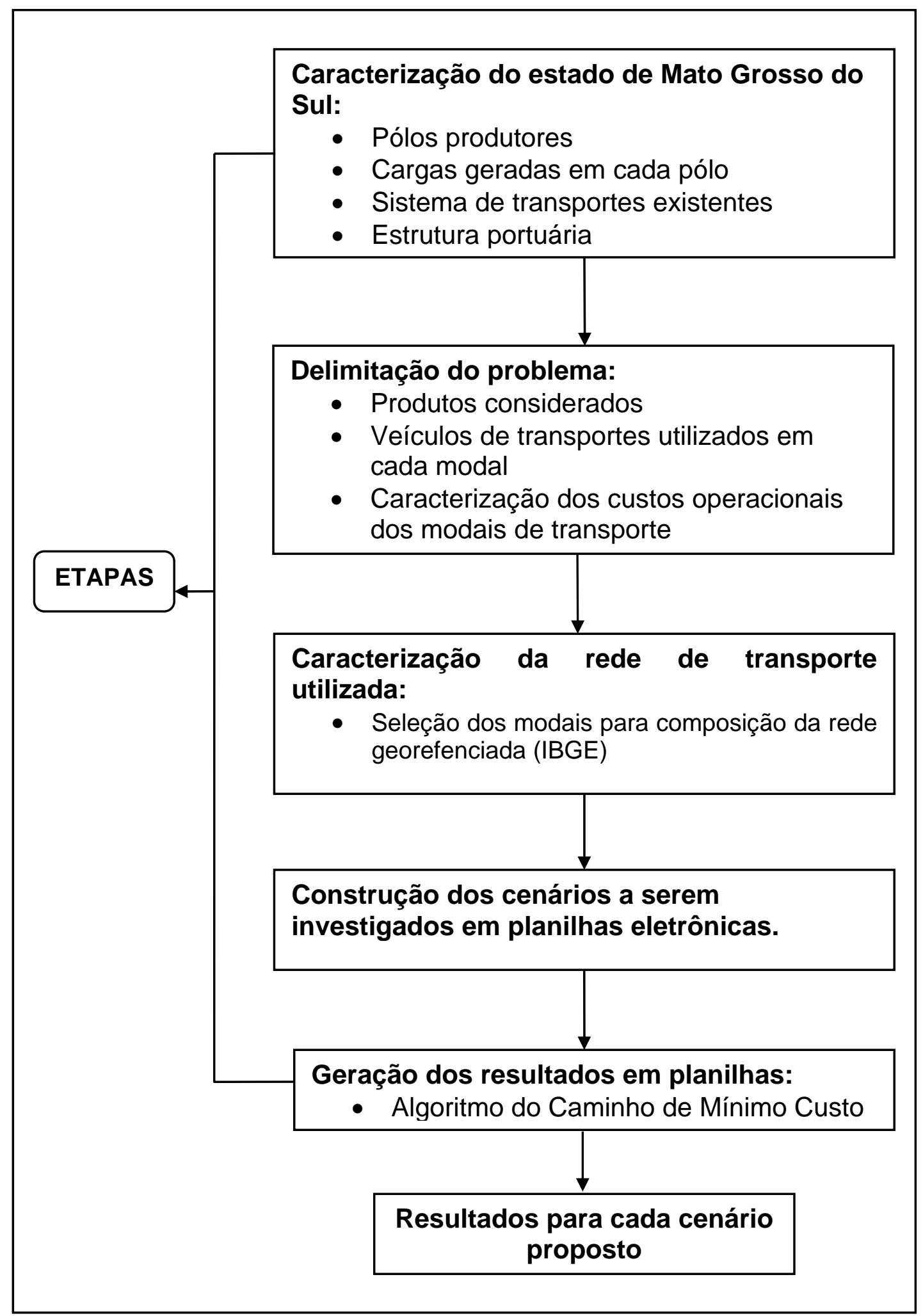

Figura 3.1 - Fluxo das etapas do método proposto Fonte: Elaborado pelo autor 


\section{CARACTERIZAÇÃO DO ESTADO DE MATO GROSSO DO SUL}

Neste capítulo é realizada a caracterização dos pólos produtores, rede de transportes existentes e estrutura portuária que serão utilizados na investigação dos cenários propostos no estado de Mato Grosso do Sul.

\subsection{PÓLOS DE PRODUÇÃO DO ESTADO E SUAS CARACTERÍSTICAS}

Para a definição dos pólos de produção e industrialização do Estado de Mato Grosso do Sul foram inicialmente utilizados dados do Instituto Brasileiro de Geografia e Estatística (IBGE), que divide o Estado em 10 microrregiões geográficas. Apresentam-se dados de produção mineral, produção agrícola, quantidade de indústrias e de modais de transporte que as atende.

\subsubsection{Pólo de Campo Grande}

Este pólo tem na agricultura e pecuária seu maior potencial de geração de cargas (IBGE, 2006).

Campo Grande (capital do Estado) é o centro comercial da região. As atividades desenvolvidas estão mais concentradas no setor de serviços, embora o município abrigue frigoríficos, indústrias de óleo vegetal, indústrias de sal mineral, entre outras.

A presença dos principais corredores de transportes do Estado - a BR 267, a BR 163, os ramais ferroviários da Novoeste, a BR 060 e a BR 262 - transforma Campo Grande no principal centro de atração de cargas. 


\subsubsection{Pólo de Dourados}

A região tem seu foco na produção de grãos, abrigando também três destilarias (Nova Alvorada, Rio Brilhante e Maracaju), indústrias de rações (Dourados e Caarapó), de óleo vegetal (Dourados), de carne de aves (Dourados) e de carne bovina (Itaporã e Caarapó) (IBGE, 2006).

As cargas da região são movimentadas, pelo modal rodoviário, através das BRs 163 e 267, rumo aos portos de Santos e de Paranaguá. Esta situação poderá se transformar caso sejam restabelecidas as operações da Novoeste através do ramal de Ponta Porã. A ligação asfáltica de Ponta Porã a Porto Murtinho, atualmente em fase de definição, fará com que parte das cargas destinadas à exportação venha a ser escoada por aquele porto.

\subsubsection{Pólo de Naviraí}

A criação de gado para corte é o grande destaque da região, apesar do potencial agrícola, da vocação agro-industrial de Naviraí e do grande potencial da bacia leiteira. O pólo possui frigoríficos, destilaria, fecularias, laticínios e indústria de sal mineral.

As cargas da região são escoadas, majoritariamente, pela BR 163, com destino aos mercados do Paraná, de Santa Catarina e de São Paulo. O modo hidroviário será o concentrador das cargas da região, assim que existirem condições plenas de embarque à margem direita da hidrovia Tietê-Paraná e os volumes a serem transportados sejam mais significativos.

\subsubsection{Pólo de Três Lagoas}

A grande maioria das terras da região é constituída de solos arenosos, desaconselháveis inclusive para pastagem plantada. A exceção fica por conta de uma parcela do município de Água Clara, ocupado largamente pela agricultura mecanizada e pelas terras de Paranaíba e Aparecida do Taboado, tradicionalmente ocupadas com pecuária intensiva.

As cargas da região, atualmente, são escoadas pelos modais ferroviário e rodoviário. A produção agrícola se escoa quase que totalmente por Chapadão do Sul, pela Ferronorte, já que se concentra ao norte do município de Água Clara. Os frigoríficos situados em Paranaíba e Aparecida do Taboado escoam 
sua produção pelo modal rodoviário através da ponte rodoferroviária de Aparecida do Taboado.

Três Lagoas tende a ser um importante centro comercial e industrial, estimulado pela confluência dos modais rodoviário, ferroviário e hidroviário, além do gasoduto Brasil-Bolívia. A cidade é servida pela ferrovia Novoeste, pela BR 262 - os dois grandes corredores Leste-Oeste do Estado - e pela hidrovia Tietê-Paraná.

\subsubsection{Pólo de Chapadão do Sul}

Os municípios de Costa Rica e Chapadão do Sul são os líderes de produção agrícola do pólo; Camapuã e Alcinópolis possuem pequena produção, enquanto Cassilândia se destaca pela atividade pecuária.

As cargas de Costa Rica e de Chapadão do Sul são escoadas majoritariamente pela Ferronorte rumo aos portos de Santos e quando destinadas aos mercados de São Paulo e Paraná são escoadas preferencialmente pelo modo rodoviário.

\subsubsection{Pólo de Corumbá}

Este pólo está todo compreendido no pantanal sul-mato-grossense. A atividade predominante é a pecuária extensiva. Em termos de cargas, entretanto, a principal atividade é a extração mineral, concentrada na região de Corumbá e Ladário, no Maciço do Urucum.

As cargas da região, constituídas basicamente de produtos minerais e grãos, este último vindo em grande quantidade por ferrovia da vizinha Bolívia são, principalmente, transportados pelos modais ferroviário e hidroviário.

A grande perspectiva para Corumbá é a confluência dos modais rodoviário, hidroviário e ferroviário e do gasoduto Brasil-Bolívia, que Ihe proporciona características de centro comercial, além da perspectiva de industrialização dos produtos oriundos de extração mineral e a possibilidade da instalação do pólo petroquímico. Porto Esperança proporcionará a ligação do Mercosul e dos Países do Pacto Andino aos mercados do centro-sul brasileiro, pois reúne condições de abrigar um terminal hidroferroviário de carga geral, minério e produtos agroindustriais. 


\subsubsection{Pólo de Porto Murtinho}

Essa região se destaca pela criação extensiva de gado e facilidade de inserção no mercado internacional através do Rio Paraguai.

A perspectiva de desenvolvimento da região está atrelada ao incremento das exportações do Estado através de Porto Murtinho, já que a concessão dos serviços prestados pelo terminal prevê a execução de um plano de geração e atração de cargas para o mesmo.

\subsubsection{Pólo de Jardim}

A produção atual deste pólo, não muito significativa, se constitui basicamente de cimento e calcário sendo escoado principalmente pelo modal rodoviário, porém com possibilidade de escoamento pelo ferroviário.

\subsubsection{Pólo de São Gabriel do Oeste}

A agricultura é responsável pelo maior volume de cargas do pólo. Outra atividade importante é a produção de álcool e açúcar em Sonora e da pecuária de corte. As cargas da região são movimentadas pela BR 163 rumo a Campo Grande ou ao mercado do centro-sul do País.

\subsubsection{Pólo de Nova Andradina}

É nesta região que se localizam as terras disponíveis para o crescimento da área plantada do Estado, pois são terras com grande vocação agrícola atualmente ocupadas com a criação de gado.

Neste pólo está localizado o Porto de Bataguassu, que poderá contribuir para acelerar a ocupação de novas áreas e proporcionar avanço no nascente processo de agroindustrialização.

\subsection{SISTEMA VIÁRIO ESTADUAL}

\subsubsection{Modal Rodoviário}

A estrutura rodoviária do Estado de Mato Grosso do Sul, apresentada na Figura 4.1 e Tabela 4.1, é basicamente definida por três eixos que cortam o Estado nos sentidos norte-sul e dois no sentido leste-oeste. 
Um dos eixos leste-oeste é formado pela rodovia federal BR 262, que interliga as cidades de Corumbá e Ladário (no oeste) com Três Lagoas (no leste) e, desta, com a rodovia Marechal Rondon já no interior do Estado de São Paulo.

Outro eixo, nesta mesma direção, é constituído pela rodovia BR 267, que corta o sul do Estado, estabelecendo a ligação entre Porto Murtinho (na região oeste) e Bataguassu (Ponte Maurício Joppert) no leste - conectando-se, em Presidente Epitácio (Estado de São Paulo), com as redes rodoviárias (rodovia Raposo Tavares) e ferroviária daquele Estado. A rigor, são estabelecidos dois tramos: um leste, até o entroncamento com a BR 163 em Nova Alvorada do Sul e outro, a oeste, também a partir desta rodovia, na altura de Rio Brilhante.

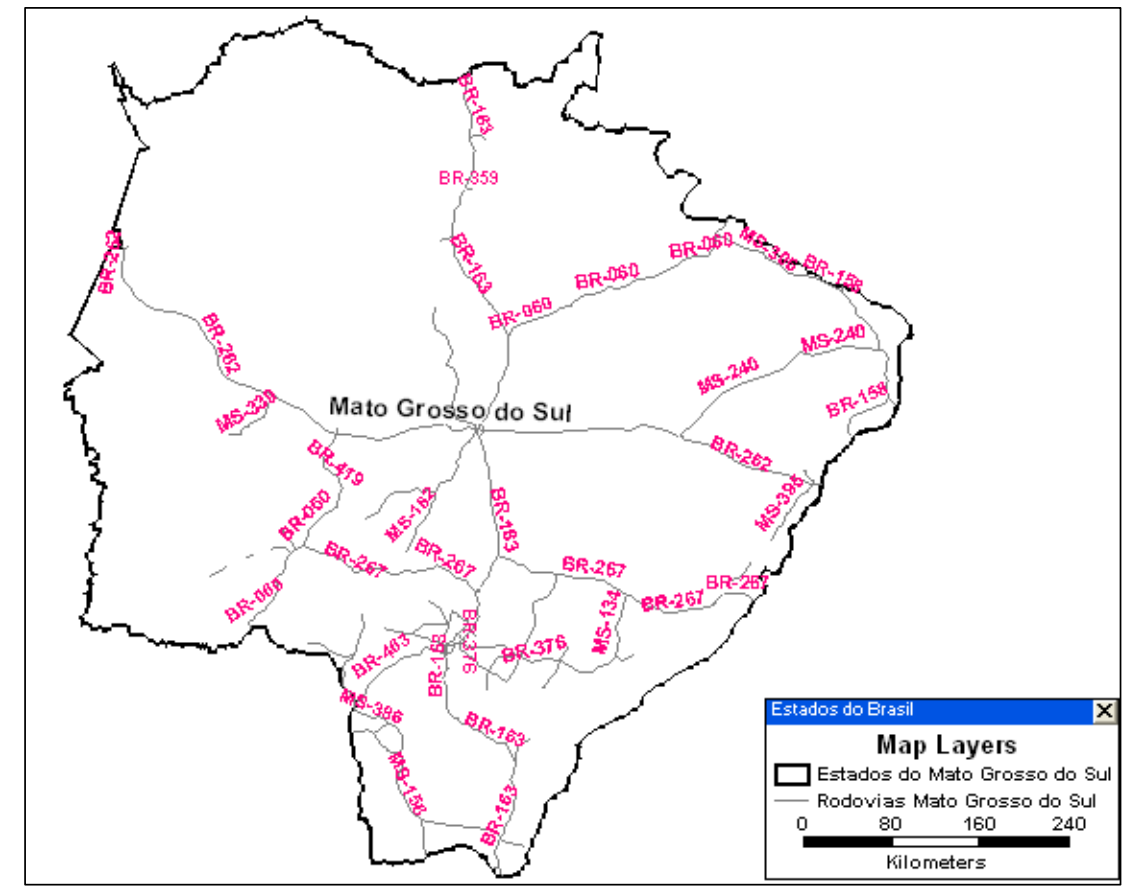

Figura 4.1 - Rede rodoviária de Mato Grosso do Sul Fonte: Elaborado pelo autor

O tramo oeste é de vital importância no contexto dos pólos de Porto Murtinho, de Jardim e de Dourados, por ser a única opção de conexão entre eles.

No sentido norte-sul desenvolve-se a BR 163, cortando o Estado desde Mundo Novo, no sul, até Sonora, já na divisa com o Estado de Mato Grosso. É uma importante rodovia, por articular o norte do Paraná à região sul do Estado (em especial ao pólo de Dourados); o pólo de Campo Grande ao pólo de São Gabriel do Oeste e, deste, ao Estado de Mato Grosso. 
Outra ligação, também estrutural, conecta este eixo (BR 163) na altura de Camapuã, com a região nordeste em Chapadão do Sul, permitindo acesso a Cassilândia, Paranaíba e Aparecida do Taboado. Trata-se de uma ligação que teve incremento no fluxo de carga com o início de operação da Ferronorte, que conta com um terminal de grãos em Chapadão do Sul.

De acordo com informações do Ministério dos Transportes, a malha viária totaliza 56 mil km, dos quais 4 mil km são federais, 14 mil são de jurisdição estadual e 38 mil km são estradas municipais.

Quanto ao pavimento, predomina a existência de vias em terra, implantadas ou em leito natural. A extensão da malha pavimentada é de $5 \mathrm{mil} \mathrm{km}$, o que representa $9,87 \%$ do total. Há, ainda, um total de $3 \mathrm{mil} \mathrm{km}$ de rodovias planejadas.

De modo geral, os trechos mais solicitados são formados pelas ligações da BR 163 entre Dourados e o entroncamento com a BR 267 e desta rodovia até o acesso ao Estado de São Paulo em Bataguassu (Ponte Maurício Joppert). É neste trecho que se observa a maior concentração de veículos comerciais da malha, com uma participação de 70 a $85 \%$ no fluxo de veículos, indicador da formação de uma importante rota de transporte de carga.

Regionalmente, observam-se distintas distribuições da malha rodoviária. A densidade de vias pavimentadas que oferecem boa conexão entre municípios limita-se à região sul, em especial ao pólo de Dourados.

A região central também é atendida com algumas vias pavimentadas, muito em função da posição estratégica no Estado e devido à localização da capital. Já as regiões leste, norte e parte da oeste apresentam boa densidade de vias, porém a maior parte em terra. As vias pavimentadas restringem-se às rodovias federais e a algumas estaduais.

Nos pólos de Porto Murtinho e de Corumbá são encontradas as menores concentrações da malha rodoviária, em função destes pólos estarem localizados na área do Pantanal.

A análise combinada da infra-estrutura rodoviária com outros modais de transportes permite identificar que, além da recuperação física das vias estruturais, é necessária a ampliação da malha rodoviária de caráter 
alimentador, especialmente nas regiões oeste (pólo de Jardim), norte (pólo de São Gabriel do Oeste) e nordeste (pólo de Chapadão do Sul).

Tabela 4.1 - Administração das rodovias em MS

\begin{tabular}{ccccc}
\hline \multicolumn{5}{c}{ Extensão $(\mathbf{k m})$} \\
\hline Administração & Planejada & Leito Natural & Pavimentada & Total \\
\hline Federal & 327 & 396 & 3.355 & 4.078 \\
\hline Estadual & 2.834 & 9.081 & 2.220 & 14.135 \\
\hline Municipal & 0 & 38.629 & 42 & 38.671 \\
\hline Total & 3.161 & 48.106 & 5.617 & 56.884 \\
\hline
\end{tabular}

Fonte - Ministério dos transportes (2006).

\subsubsection{Modal Ferroviário}

A malha ferroviária utilizada pelo Estado de Mato Grosso do Sul é composta das ferrovias Novoeste e Ferronorte, que atravessam o Estado, a Ferroban localizada no estado de São Paulo, a malha da ALL no estado do Paraná, sendo todas essas controladas pela ALL - América Latina Logística, além da Ferropar, localizada no Estado do Paraná, alimentada por via rodoviária na cidade de Cascavel - PR.

\section{a - Ferrovia Novoeste}

O sistema operado pela Novoeste, empresa concessionária da antiga malha oeste da RFFSA (linha SR 10) possui um total de 1.208 km, desde Bauru (SP) até Corumbá (MS). O tramo principal corta o Estado na direção leste-oeste, ligando Três Lagoas a Corumbá em bitola métrica (ANTF, 2006).

A leste estende-se até Bauru, onde se conecta ao restante da malha ferroviária do Estado de São Paulo, atingindo o Porto de Santos. Já no extremo oeste, conecta-se à Ente Nacional de Ferrocarriles (ENFE) boliviana, que se prolonga até Santa Cruz de La Sierra. Completa o sistema um ramal até Ponta Porã, com 304 km, que liga esta cidade até a linha tronco em Indubrasil. A linha principal conta, ainda, com ramais ligando-a a Porto Esperança e a Ladário, ambos em Mato Grosso do Sul na barranca do Rio Paraguai (ANTF, 2006).

Os principais produtos transportados são combustíveis e derivados de petróleo, soja, minério de ferro, cimento, manganês e produtos siderúrgicos. 
Contudo, a operação desta ferrovia encontra-se praticamente paralisada, pois sua malha e seus materiais rodantes apresentam-se em péssimo estado de conservação, havendo necessidade de investimentos urgentes para a recuperação da malha, especialmente, em obras de substituição de dormentes, travamento de curvas e sinalização.

O traçado da Ferrovia Novoeste está ilustrada na Figura 4.2.

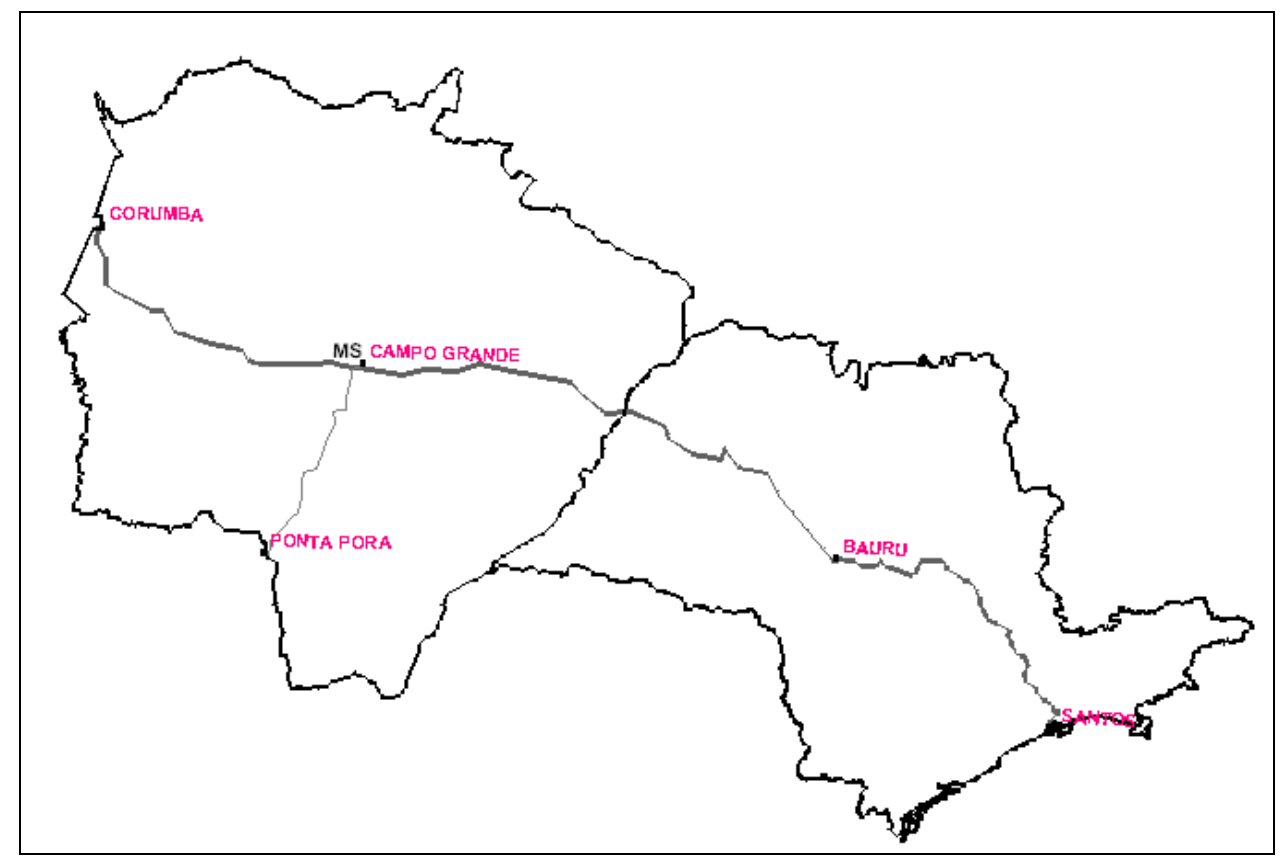

Figura 4.2 - Ferrovia Novoeste

Fonte: Elaborado pelo autor

\section{b - Ferrovia Ferronorte}

O sistema Ferronorte é de implantação recente, já que suas operações foram iniciadas no ano de 1999, tendo no transporte de grãos para exportação seu principal produto. É uma ferrovia que em sua concepção original se interligará a uma rede com $5.228 \mathrm{~km}$ de linhas férreas, conectando os Estados de Mato Grosso do Sul, Mato Grosso, Minas Gerais, Rondônia e Pará diretamente com o Porto de Santos (ALL, 2006).

Na primeira etapa foram implantados $410 \mathrm{~km}$ de linhas, em bitola larga, entre Aparecida do Taboado (localizada em Mato Grosso do Sul, na divisa com São Paulo) e Alto Taquari (Mato Grosso) (ALL, 2006).

Nos quatro municípios de Mato Grosso do Sul por ela percorridos, foram localizados terminais destinados à concentração de carga, especialmente em 
Chapadão do Sul, com capacidade para 10 mil toneladas/dia e, em Inocência, para 5 mil toneladas/dia.

Em Aparecida do Taboado, as composições passam a utilizar o ramal da antiga Fepasa na ligação com o Porto de Santos, via Campinas.

A Figura 4.3 apresenta o trecho utilizado da Ferrovia Ferronorte.

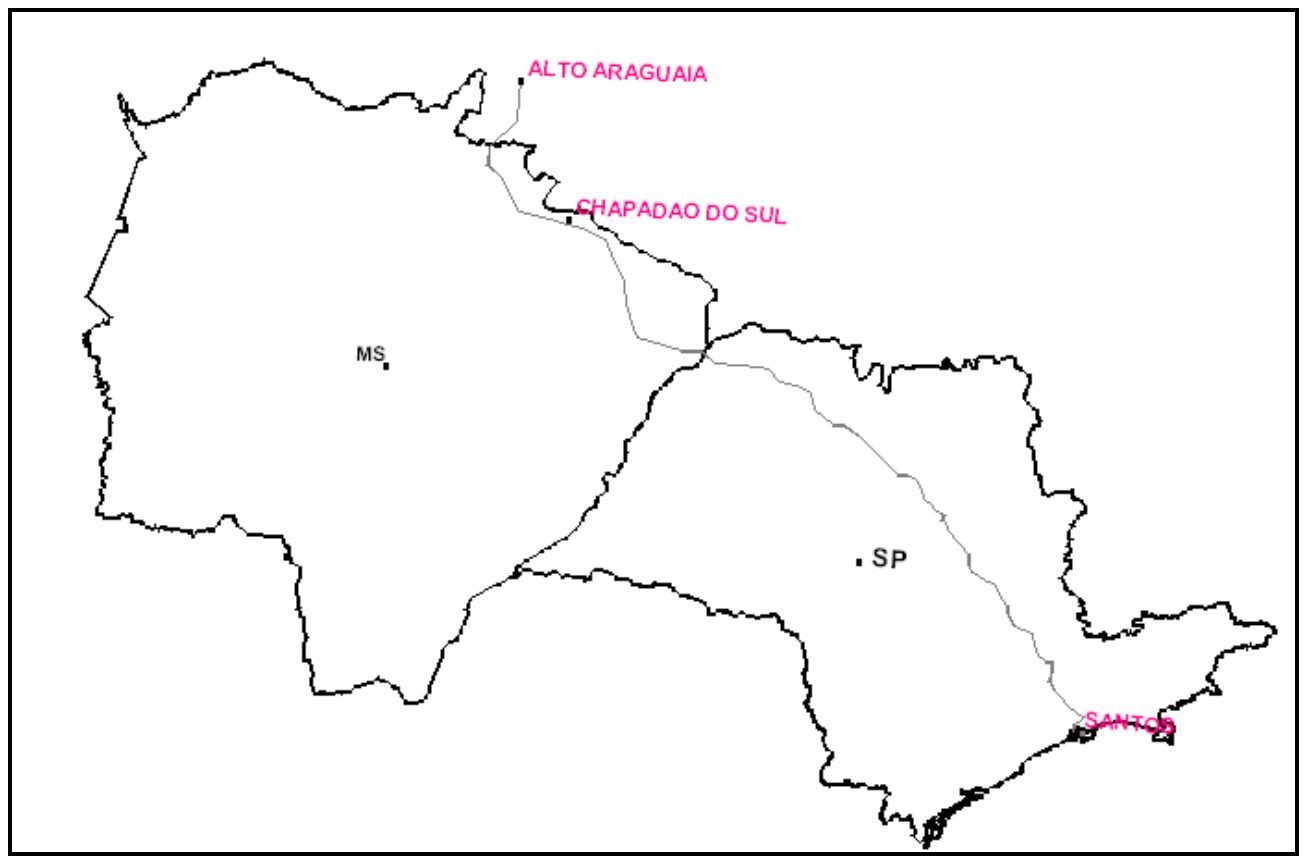

Figura 4.3 - Ferrovia Ferronorte

Fonte: Elaborado pelo autor

\section{c - Ferrovia Ferroban}

A FERROBAN - Ferrovias Bandeirantes S.A. assumiu o controle de operações da malha paulista da Rede Ferroviária Federal S.A., antiga FEPASA, em $1^{\circ}$ de janeiro de 1999, por 30 anos.

Atualmente a FERROBAN pertence à ALL (América Latina Logística), passando assim a integrar juntamente com a Novoeste e Ferronorte, os corredores ferroviários Corumbá (MS)/Santos, em bitola métrica, e Alto Araguaia (MT)/Santos, em bitola larga, ligando importantes regiões exportadoras do Brasil e da Bolívia ao Porto de Santos (São Paulo) (ANTF, 2006).

A malha desta ferrovia possui uma extensão total de $4.186 \mathrm{~km}$, sendo $1.463 \mathrm{~km}$ em bitola larga, $2.427 \mathrm{~km}$ em bitola métrica e 296 em bitola mista (TRANSPORTES, 2006). 
O trecho utilizado para este trabalho é ilustrado na Figura 4.4.

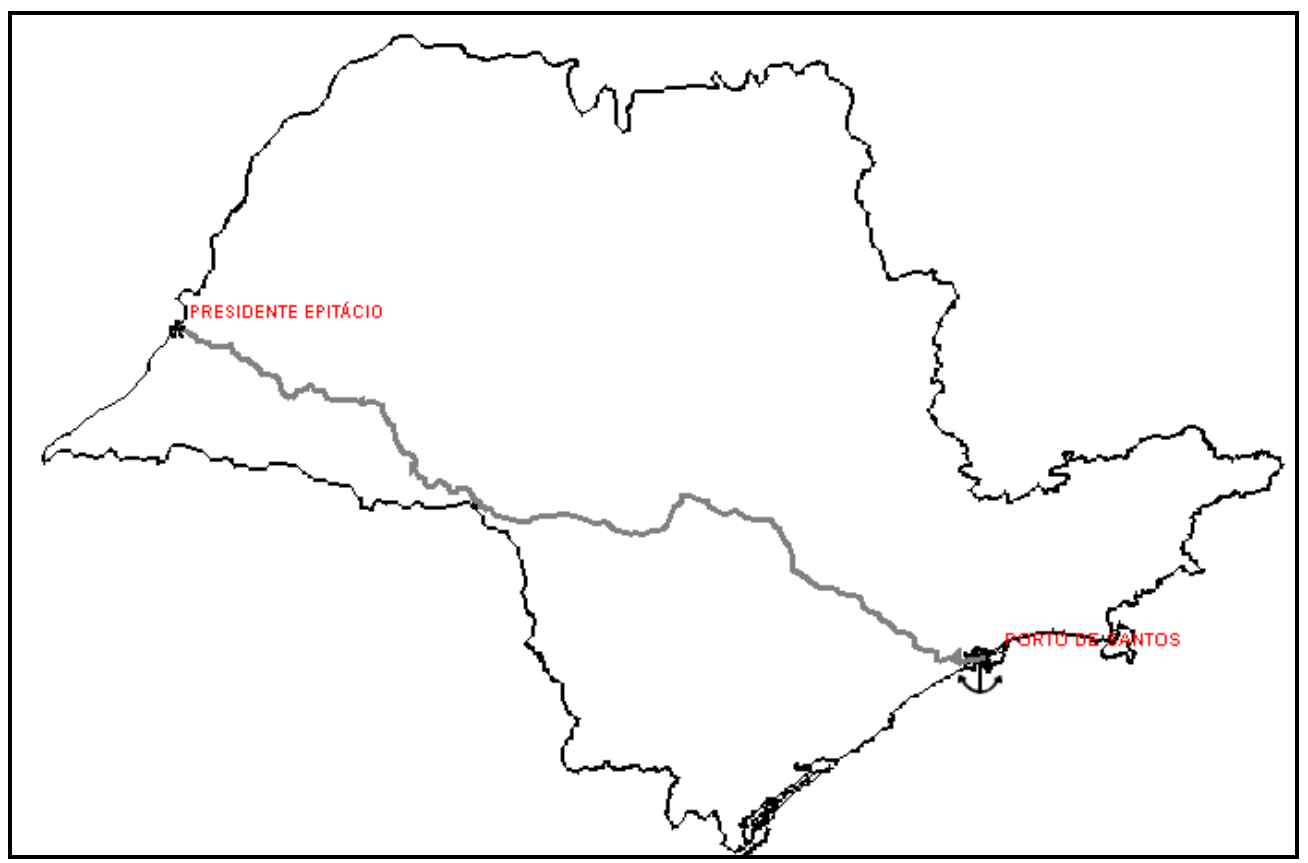

Figura 4.4 - Ferrovia Ferroban

Fonte: Elaborado pelo autor

\section{d - ALL - Paraná}

A empresa foi fundada em março de 1997, quando a Ferrovia Sul Atlântico venceu o processo de privatização da malha sul da Rede Ferroviária Federal e passou a operar a malha no Paraná, Santa Catarina e Rio Grande do Sul.

Em 1998, por meio de contrato operacional, a companhia assumiu as operações da malha sul paulista pertencente à Ferroban.

Com a aquisição das ferrovias argentinas Ferrocarril Mesopotâmico, General Urquiza e Ferrocarril Buenos Aires al Pacifico General San Martin, em 1999, a empresa passou a adotar o nome América Latina Logística (ANTF, 2006).

Em julho de 2001, a ALL integrou a Delara Ltda, uma das maiores empresas de logística do País e assumiu as operações e contratos comerciais da empresa no Brasil, Chile, Argentina e Uruguai.

Com a aquisição da Brasil Ferrovias e da Novoeste, em maio de 2006, a ALL consolidou sua posição de maior empresa ferroviária da América do Sul, passando a operar no Mato Grosso e Mato Grosso do Sul.

Atualmente a ALL administra uma malha férrea de 20.495 quilômetros de extensão, cobrindo o Sul de São Paulo, Paraná, Santa Catarina e Rio Grande 
do Sul, a região central da Argentina. A Companhia cruza as fronteiras do Paraguai e Uruguai e serve o Chile por rodovia a partir da base logística intermodal de Mendoza, na Argentina. Seis dos mais importantes portos do Brasil e Argentina são atendidos pela ALL (ALL, 2006).

A Figura 4.5 apresenta o trecho utilizado neste estudo.

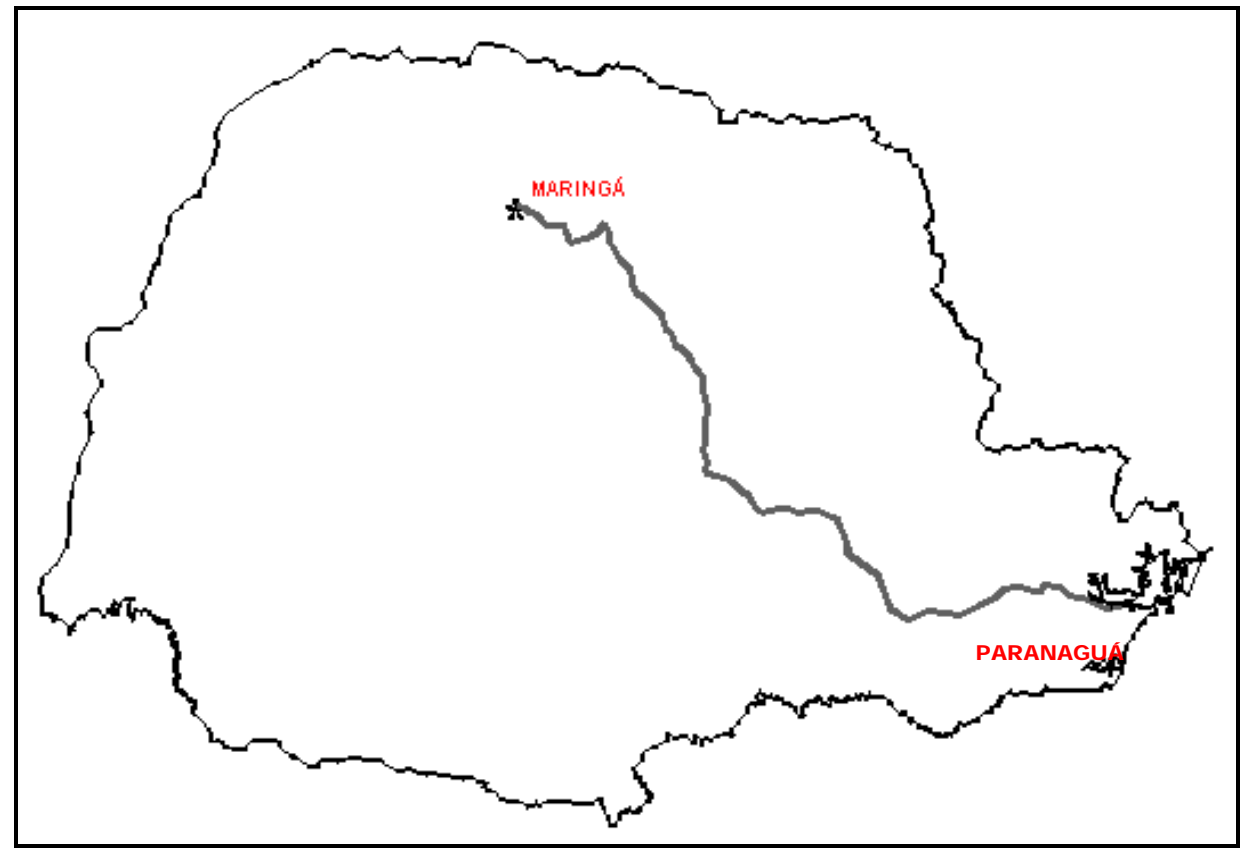

Figura 4.5 - ALL Paraná

Fonte: Elaborado pelo autor

\section{e - Ferrovia Ferropar}

Com início em Cascavel e término em Guarapuava, conforme apresentado na Figura 4.6, ambos, no Estado do Paraná, esta ferrovia possui extensão de 249,4 km e bitola de 1,00 m, sendo muito utilizada para o escoamento de grãos do estado de Mato Grosso do Sul (MINISTÉRIO DOS TRANSPORTES, 2006).

Sua área de influência atinge o oeste e sudoeste do Paraná, Mato Grosso do Sul e as regiões produtoras de grãos e cereais da Argentina e do Paraguai. Tem ainda como projeto seu prolongamento até Maracajú, no estado de Mato Grosso do Sul e até Foz do Iguaçu, no estado do Paraná.

Os embarques em Cascavel são realizados no terminal de transbordo, que faz a transferência das cargas recebidas dos caminhões para os vagões e viceversa. Trata-se de um terminal de graneis sólidos, destinado a receber cargas rodoviárias e realizar o transbordo para vagões, assim como receber cargas ferroviárias e efetuar a transferência para caminhões (FERROPAR, 2006). 
Além deste terminal, Cascavel possui outros terminais de propriedade de grandes companhias de comércio de grãos que realizam transferência e armazenagem.

Em Guarapuava ocorre a conexão com a linha da ALL (América Latina Logística), onde esta segue mais $490 \mathrm{~km}$ até o porto de Paranaguá, perfazendo um total de $739 \mathrm{~km}$ de trecho ferroviário dentro do estado do Paraná.

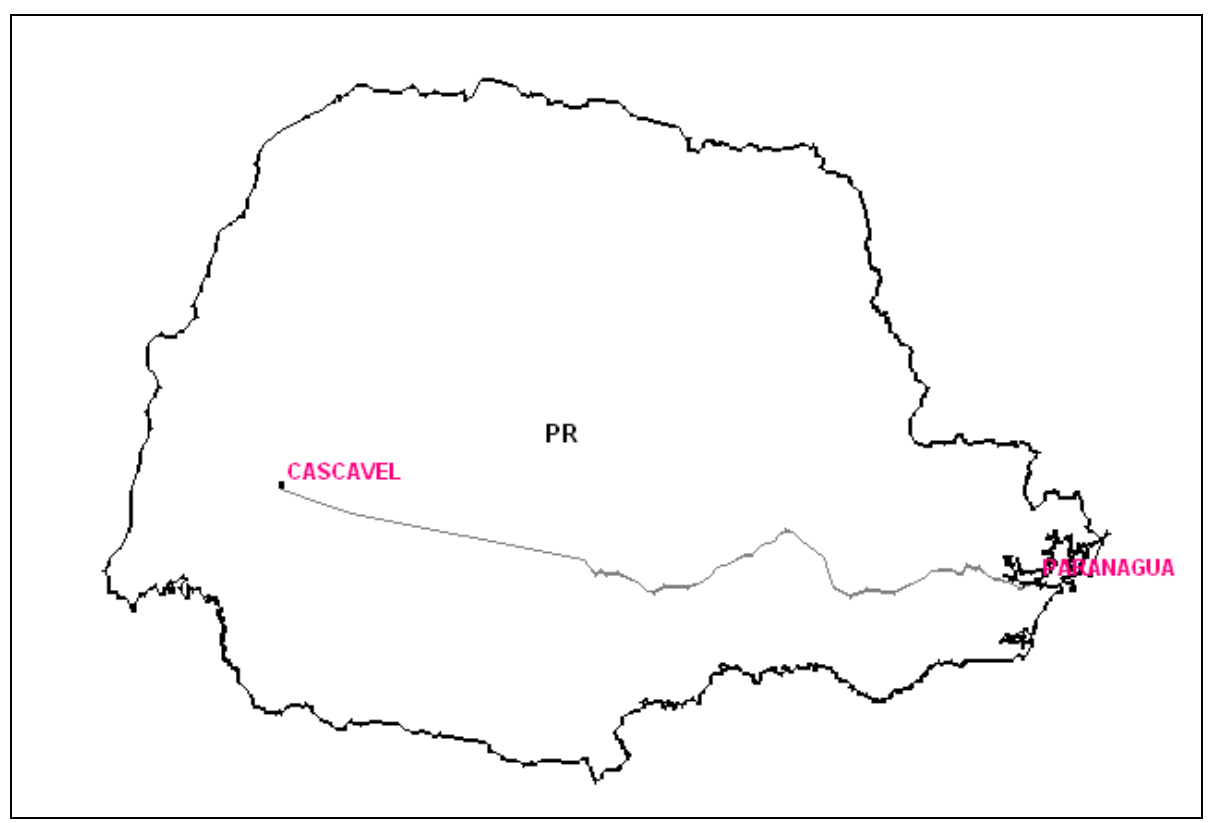

Figura 4.6 - Ferrovia Ferropar

Fonte: Elaborado pelo autor

\subsubsection{Modal Hidroviário}

O Estado de Mato Grosso do Sul é privilegiado quanto a recursos hídricos, pois esta inserido em duas grandes bacias hidrográficas, do Paraná e do Paraguai.

\section{a - Hidrovia Paraguai-Paraná}

A hidrovia Paraguai-Paraná, ilustrada na Figura 4.7, compreende os rios Paraguai e Paraná, desde Cáceres (MT) - Brasil até Nueva Palmira - Uruguai, incluindo o canal do Tamengo, afluente do rio Paraguai, compartilhado pela Bolívia e Brasil.

Desaguando direto no oceano Atlântico, a grande vantagem logística para os produtos ali transportados é a diminuição no número de transbordos de cargas (CAIXETA, 2000). 
O sistema fluvial da hidrovia Paraguai-Paraná serve o eixo norte-sul e cruza cinco países, quatro deles componentes do bloco Mercosul. Abrange uma área de 1,75 milhões de quilômetros quadrados, formando um sistema de navegação de $3442 \mathrm{Km}$ de rios navegáveis o ano todo e constitui um dos principais sistemas hidroviários do mundo em corrente livre, permitindo um tráfego quase ininterrupto; tem sido um importante fator para 0 desenvolvimento dos países da região, tanto do ponto de vista econômico como político e social (AHIPAR, 2006). A Figura 4.7 detalha as distâncias desta hidrovia no Brasil.

De modo geral, toda a Hidrovia está constituída por cursos d'água que podem ser classificados como de planície, com leitos arenosos e inclinações muito baixas, que os tornam razoavelmente estáveis e com pontos críticos à navegação bem identificados e caracterizados (AHIPAR, 2006).

O Rio Paraguai reflete as características de sua bacia, apresentando somente uma declividade elevada em seu curso superior, a montante de Cáceres, numa extensão de $370 \mathrm{~km}$. Nos restantes $2.250 \mathrm{~km}$ tem declividades muito baixas, correndo o rio em amplos leitos arenosos escavados na Planície Central Sul Americana (AHIPAR, 2006).

Quanto aos aspectos de navegabilidade, a hidrovia está dividida em 5 segmentos de distintas características de navegabilidade (AHIPAR, 2006):

$\left.1^{\circ}\right)$ O trecho entre Cáceres e Corumbá / Porto Aguirre é navegável por embarcações com calado máximo de 2,10 m entre os meses de fevereiro a agosto e de 1,5 m durante o resto do ano; tem traçado sinuoso e estreito, com alguns pontos de leito móvel, ocorrendo com freqüência à acumulação de balseiros nas curvas e areias em pontos determinados "passos", que tornam a navegação problemática.

$2^{\circ}$ ) No segmento entre Corumbá / Porto Aguirre e a foz do Rio Apa existem restrições de 4 passos críticos de navegação, destacando-se as passagens pela ponte ferroviária de Porto Esperança e pela ponte Rodoviária de Morrinhos, ambas sobre o Rio Paraguai, onde é obrigatório o fracionamento dos grandes comboios. 
$3^{\circ}$ ) Entre a Foz do Rio Apa e Assunção no Paraguay, as condições de navegação ficam restritas a passos com presença de pedra, o que exige 0 desmembramento dos comboios e restringem a navegação noturna. Estas pedras necessitam serem removidas, pois são as principais responsáveis pelos acidentes de navegação. O calado máximo de navegação observado neste trecho é de $2,70 \mathrm{~m}$.

$4^{\circ}$ ) De Assunção (PY) a Santa Fé (AR), as condições são favoráveis para navegação permanente de comboios, que atingem até 300 metros de comprimento, largura de 50 metros e calado de 3,0 metros.

$\left.5^{\circ}\right)$ No rio Paraná inferior, desde Santa Fé até o canal Martin Garcia, compartilhado pelo Uruguai e Argentina, trafegam navios de alto mar com calados de até 8 metros; neste trecho podem navegar, praticamente sem restrições, comboios de empurra com largura de $50 \mathrm{~m}$, comprimento de $300 \mathrm{~m}$ e calado superior a $3 \mathrm{~m}$ durante todo o ano.

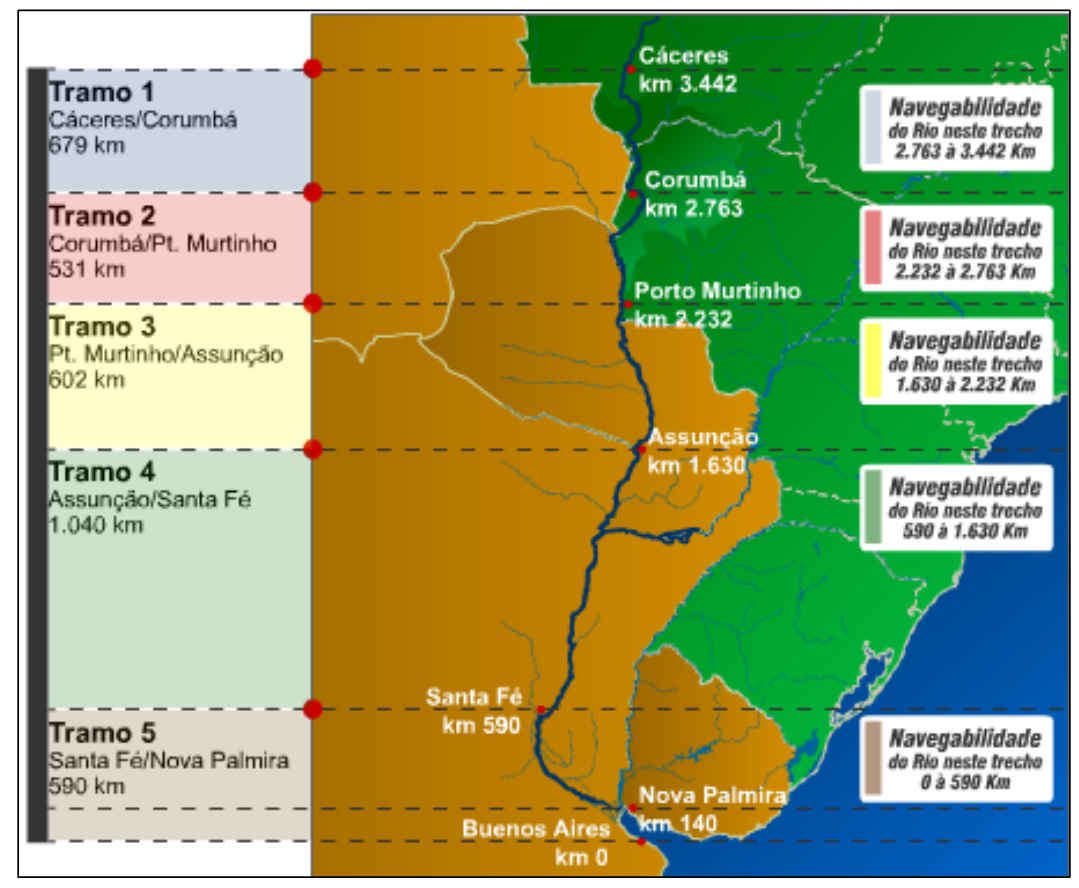

Figura 4.7 - Hidrovia Paraguai-Paraná

Fonte: AHIPAR, 2006

Além destes trechos, existem mais dois trechos que merecem comentário:

O primeiro, na região do alto Paraná, desde Pùerto Iguaçu / Cuidad del Este até Resistência / Corrientes, a navegação é dificultada pela existência de forte correnteza, muitos baixios e pedras, além da eclusa de Yaciretá (Paraguai / Argentina). 
O segundo, acima de Nueva Palmira, no rio Uruguai, até Fray Bentos (90 km acima), cujo tramo ainda não foi muito explorado para navegação de comboios, mas permite uma franca navegação.

Dadas as condições atuais de navegação e as características climáticas da região, o modal hidroviário só pode estar disponível durante uma parte do ano, dificultando a manutenção do fluxo estável de mercadoria durante o ano.

Essa sazonalidade afeta cada mercadoria diferentemente. Apesar da coincidência do período de colheita com o período de cheia, a disponibilidade sazonal ainda implica em custos mais altos para as empresas obrigadas a garantir o transporte através dos modais mais caros.

Os custos mais altos de transporte implicam na perda de competitividade e poderiam induzir os produtores a reduzir suas atividades durante essas estações de seca.

Quanto à capacidade e dimensões dos comboios por trecho, atualmente se pratica na hidrovia as dimensões máximas dos comboios, por trechos de navegação segundo o Regime Único de Dimensões Máximas de Comboios onde, basicamente, desde Corumbá até Nova Palmira se pode navegar com comboios de até 290 metros de comprimento por 50 metros de largura, com até 30 mil toneladas de carga. Em alguns trechos o comprimento é reduzido para 236 metros.

No tramo do Alto - Paraná Toro Cua x Corriente, os comboios são formados: desde Toro Cua até Paloma com 180 × 30 metros, equivalentes a 06 barcaças tipo Mississipi. No trecho de Paloma até Corrientes navega-se atualmente com comboios de 240 × 40 metros (12 a 16 barcaças tipo Mississipi), com desmembramento pela eclusa de Yaciretá (CEPE, 2001).

Tabela 4.2 - Distâncias da hidrovia do Paraguai

Trecho

\begin{tabular}{lc}
\hline Cáceres (MT/Brasil) - Nueva Palmira (Uruguay) & 3.442 \\
\hline Corumbá e Ladário - Nueva Palmira & 2.770 \\
\hline Porto Murtinho - Nueva Palmira & 2.232 \\
\hline Cáceres - Foz do rio Apa (MS/Brasil) & 1.298 \\
\hline Divisa Mato Grosso do Sul/Mato Grosso à foz do rio Apa & 858 \\
\hline
\end{tabular}

Extensão (km) 3.442 2.770 858 


\section{b - Hidrovia Tietê-Paraná}

O transporte regional de cana-de-açúcar e calcário marcou o início da operação comercial do sistema hidroviário, em 1981, numa extensão de 300 $\mathrm{km}$. A abertura do Canal de Pereira Barreto - ponto de encontro dos dois rios veio possibilitar, a partir de 1991, a operação do tramo norte do rio Paraná e, conseqüentemente, o transporte de longo curso, nessa ocasião já com extensão navegável de $1.100 \mathrm{~km}$, atingindo o sul de Goiás e o oeste de Minas Gerais (SECRETARIA DE ESTADO DOS TRANSPORTES - SÃO PAULO, 2006).

Atualmente, o Sistema Hidroviário Tietê-Paraná, apresentado na Figura 4.8, possui $2.400 \mathrm{~km}$ de vias navegáveis, dos quais $600 \mathrm{~km}$ servem ao estado de Mato Grosso do Sul, atendendo um total de 15 municípios do estado (AHRANA, 2006).

O sistema liga cinco dos maiores Estados produtores de grãos do país (São Paulo, Paraná, Minas Gerais, Goiás e Mato Grosso do Sul) e forma, juntamente com o rio Paraguai em seus trechos argentino e paraguaio, uma rede hidroviária de aproximadamente oito mil quilômetros sendo, portanto, considerado como parte da Hidrovia do Mercosul.

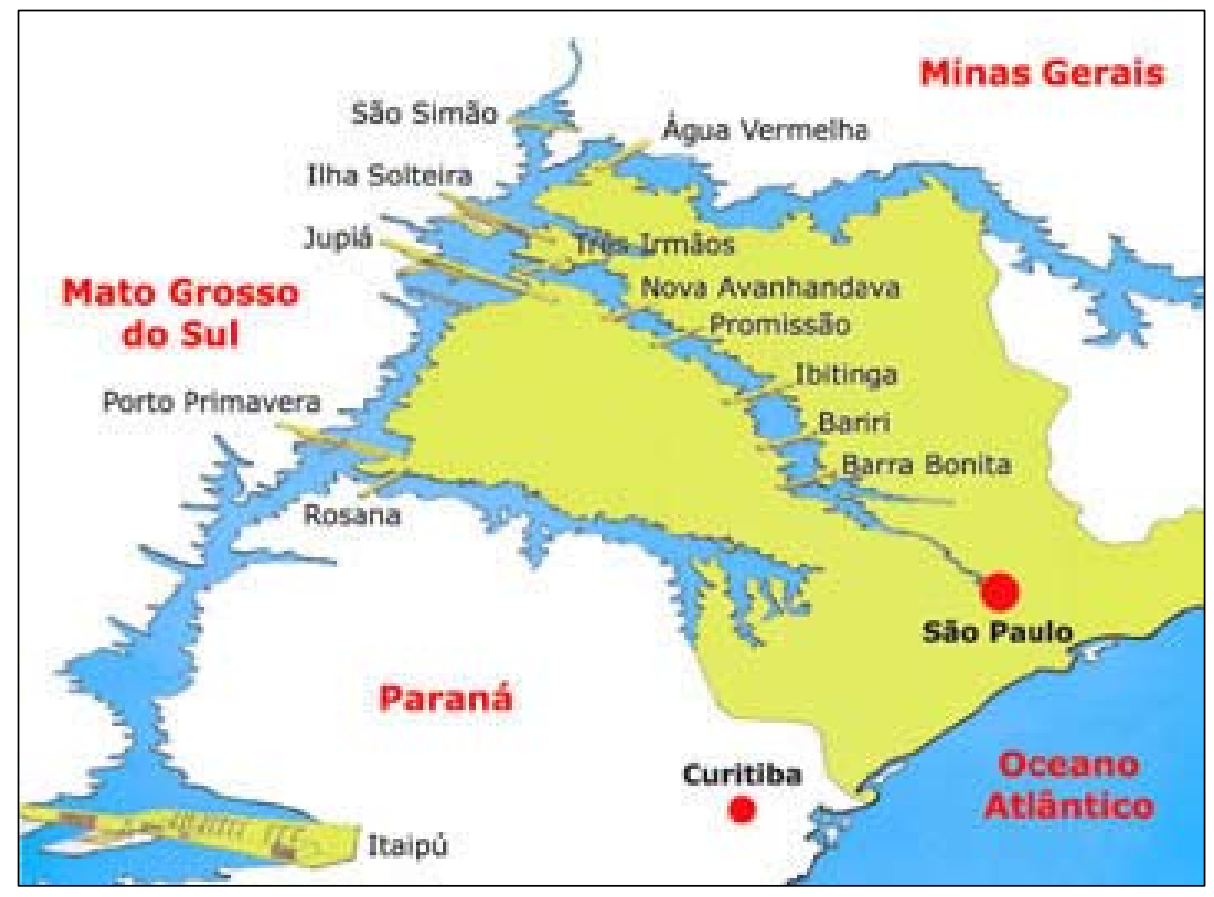

Figura 4.8 - Hidrovia Tietê-Paraná

Fonte: AHRANA, 2006 
A hidrovia Paraná-Tietê compreende $600 \mathrm{~km}$ do rio Tietê, canalizado desde o terminal de Conchas (no final do remanso da barragem de Barra Bonita) até a foz no rio Paraná (no lago da barragem de Jupiá); 790 km do "Tramo Norte" constituído pelo canal de Pereira Barreto, por trecho do rio São José dos Dourados, inundado pelo lago da barragem de llha Solteira e pelo lago dessa barragem até o pé das barragens de São Simão, no rio Paranaíba, e de Água Vermelha, no rio Grande; $660 \mathrm{~km}$ do "Tramo Sul", correspondente a $500 \mathrm{~km}$ do rio Paraná, navegável em corrente livre desde o pé da barragem de Jupiá até a cidade de Guaíra (PR) e 160 km do lago da barragem de Itaipu (MINISTÉRIO DOS TRANSPORTES, 2006).

As eclusas do rio Tietê têm $142 \mathrm{~m}$ de comprimento, $12 \mathrm{~m}$ de largura e profundidade mínima de $3,50 \mathrm{~m}$. São ao todo oito eclusas, sendo duas na barragem de Três Irmãos e duas na de Nova Avanhandava. Já as eclusas do rio Paraná (Jupiá e Porto Primavera) possuem uma dimensão maior, com 210 $\mathrm{m}$ de comprimento por $17 \mathrm{~m}$ de largura e uma profundidade mínima de $5 \mathrm{~m}$. (MINISTÉRIO DOS TRANSPORTES, 2006). A tabela 4.3 apresenta as dimensões das eclusas da hidrovia Tietê - Paraná.

Tabela 4.3 - Eclusas da hidrovia Tietê-Paraná

\begin{tabular}{lccc}
\hline \multicolumn{1}{c}{ ECLUSAS } & $\begin{array}{c}\text { Comprimento } \\
(\mathbf{m})\end{array}$ & $\begin{array}{c}\text { Largura } \\
(\mathbf{m})\end{array}$ & $\begin{array}{c}\text { Profundidade } \\
(\mathbf{m})\end{array}$ \\
\hline Barra Bonita & 147,25 & 11,76 & 3,50 \\
\hline Bariri & 142,00 & 12,02 & 3,50 \\
\hline Ibitinga & 142,45 & 12,04 & 3,50 \\
\hline Promissão & 142,00 & 12,00 & 3,50 \\
\hline N. Avanhandava sup. & 142,00 & 12,10 & 3,50 \\
\hline N. Avanhandava inf. & 142,00 & 12,10 & 3,50 \\
\hline Três Irmãos sup. & 142,00 & 12,10 & 3,50 \\
\hline Três Irmãos inf. & 142,00 & 12,10 & 3,50 \\
\hline Jupiá & 210,00 & 17,00 & 5,00 \\
\hline Porto Primavera & 210,00 & 17,00 & 5,00 \\
\hline
\end{tabular}

Fonte: Secretaria de Estado dos Transportes de São Paulo (2006) 
A área de influência da hidrovia do Mercosul é responsável por $80 \%$ do PIB dos países integrantes da bacia do Prata e está inserida na área mais importante do Tratado do Mercosul. A produção anual de grãos da região supera os 150 milhões de toneladas e esta têm um potencial energético instalado superior a 25 mil MW, que dá suporte a uma industrialização crescente e gera volumes impressionantes de intercâmbio de mercadorias.

A movimentação desses grãos será direcionada para a hidrovia, devido à economia e por ela se inserir no centro da região, com fácil acesso a todos os países integrantes do tratado.

A área de influência da hidrovia Tietê-Paraná está integrada a uma bem distribuída malha de rodovias e ferrovias que dá acesso aos principais portos marítimos do sul do continente.

$\mathrm{Na}$ hidrovia do Tietê destacam-se os portos fluviais de Pederneiras e de Conchas, ambos em São Paulo.

Na hidrovia do Paraná sobressaem os seguintes atracadouros: terminal rodohidroviário de São Simão (GO), às margens do rio Paranaíba, no extremo norte da hidrovia; terminal rodoferro-hidroviário de Panorama (SP) funcionando como ponto de transbordo de cargas para a ferrovia com destino a São Paulo (SP) e Santos (SP); terminal de Presidente Epitácio (SP), com as mesmas funções do terminal de Panorama, que está ligado por ferrovia a São Paulo; terminal de Três Lagoas, explorado pela Cargill; terminal de Bataguassu (estes dois últimos no estado de Mato Grosso do Sul) e terminal de Guaíra (PR), tradicional porto de exportação do oeste do Paraná por via fluvial, que está desativado.

A região servida pela hidrovia Tietê-Paraná passa por desenvolvimento das atividades relacionadas com a navegação fluvial, pela implantação de terminais e distritos industriais; instalação de estaleiros de construção naval; fundação de cooperativas, que operam com cargas identificadas com o transporte hidroviário, e formação de empresas armadoras, que exploram o transporte e a operação dos terminais de transbordo.

O prosseguimento da navegação para montante, pelo rio Tietê, será possível com a implantação de cinco barragens com eclusas, canalizando um trecho de 120 km, até Porto Góis, a jusante da cidade de Salto (SP), vencendo um desnível de $62 \mathrm{~m}$. 
O Ministério dos Transportes está iniciando os estudos de alternativas para a transposição do desnível criado pela barragem de Itaipu, objetivando a completa integração dessa bacia hidrográfica (MINISTÉRIO DOS TRANSPORTES, 2006).

\subsection{SISTEMA PORTUÁRIO QUE SERVE O ESTADO DE MATO GROSSO DO SUL}

Portos surgiram e se desenvolveram para serem as interfaces entre os deslocamentos aquaviários e terrestres de pessoas e produtos.

Os portos fluviais caracterizados neste trabalho são os que apresentam influência na movimentação dos produtos do estado de Mato Grosso do Sul, com destino à exportação. Estes terminais são de grande importância para o sistema logístico, pois realizam a integração do modal hidroviário com os modais ferroviário e rodoviário, fazendo com que os produtos ganhem competitividade através de um menor custo total.

Para efeito do estudo, não é considerado o complemento de carga em um comboio em portos fluviais intermediários ao ponto de carregamento e descarregamento dentro do trecho hidroviário.

O que se precisa analisar quando se fala em porto, então, é a cadeia logística dos meios de transporte, onde o porto aparece como elo fundamental nas trocas comerciais, seja no âmbito interno, seja no âmbito internacional.

É fundamental que o porto esteja acoplado a seu hinterland, o qual quanto mais rico economicamente melhor, pois o porto é o termômetro que mede a economia de um país, sendo inegavelmente um setor vital para a economia, já que por ele passam muitas das riquezas de um país.

O porto é um grande elo de entroncamento intermodal, devendo possibilitar a integração de todos os meios de transporte, facilitando a logística integrada e agilizando todo o processo de movimentação e deslocamento físico das cargas.

A falta de investimentos necessários por parte do Estado, bem como os arcaicos métodos de gestão portuária mostraram, ainda mais, as necessidades de modernização dos portos. Por isto foi instituída a Lei de Modernização dos 
Portos (Lei no 8.630, de 1993), que se propôs a promover as mudanças necessárias, objetivando alcançar os parâmetros mínimos internacionais adotados para movimentação de carga, de modo que fosse possível aproveitar a localização estratégica de cada terminal. Apesar de inúmeras questões ainda não estarem resolvidas decorrentes desta legislação, cujo intuito foi o de afastar o Governo das operações portuárias, pode-se citar como principais aspectos positivos os que seguem (ANTAQ, 2006):

- Descentralização administrativa com maior autonomia dos portos, através de entidades gerenciadoras de mão-de-obra;

- Unificação do comando das operações portuárias, através do operador portuário;

- Eliminação de privilégios tanto da administração do porto, dos trabalhadores e de usuários com a revogação da legislação passada;

- Instauração da competitividade, principalmente com a autorização dos terminais de uso privativo para movimentarem cargas de terceiros;

- Consolidação da legislação portuária pela lei.

Observa-se, porém, nos dias atuais, que muitos dos aspectos acima descritos apresentam certa dificuldade de implantação, haja vista que as empresas públicas não se adequaram totalmente à função que ganharam após a Lei de Modernização de Portos, ou seja, a de administrar os operadores privados e fomentar uma relação mais estável e segura entre o poder público e os empresários, além de realizar os investimentos necessários à manutenção e à modernização da infra-estrutura de uso comum.

Há ainda, inúmeros entraves e custos desnecessários que os usuários dos portos brasileiros amargam devido principalmente ao excesso de burocracia na liberação das cargas. Existem diversos órgãos governamentais na área do porto, entre eles o Ministério da Defesa, a Agência de Vigilância Sanitária (Anvisa), a Receita Federal e o Ministério da Agricultura, sendo que cada um é responsável por um tipo de documento e por conferências físicas nas mercadorias. Por não existir um cadastro único do governo, o dono da mercadoria é obrigado a fornecer a mesma informação a todos os órgãos em formulários diferentes. Esses entraves acabam levando a demoras nos portos e 
ao pagamento de altos valores em multas pelo tempo em que o navio fica parado.

Os portos ou terminais de transferências e os de exportação final, tanto fluvial quanto marítimo, utilizados para a movimentação dos produtos estudados no estado de Mato Grosso do Sul são os terminais fluviais da hidrovia TietêParaná, hidrovia Paraguai-Paraná, os portos marítimos de Paranaguá no Paraná, Santos em São Paulo e Nueva Palmira no Uruguai. São descritas a seguir as características gerais de cada um. Alguns dos portos detalhados ainda não estão preparados para o recebimento e transferência da soja e minérios, outros, porém, já são grandes pólos exportadores dos produtos.

\subsubsection{Portos Fluviais}

\section{a - Hidrovia Tietê-Paraná}

\section{a.1 - Terminal de Pederneiras (Rio Tietê)}

Especializado no desembarque de soja, farelo e milho está equipado para uma capacidade de transbordo de 1,5 milhões toneladas/ano, com previsão de expansão para 6 milhões toneladas/ano. Possui instalação para operar com fertilizantes e calcários e tem acesso rodo-ferroviário (AHRANA, 2006).

\section{a.2 - Terminal de Três Lagoas (Rio Paraná - MS)}

O terminal é de propriedade privada e o Grupo Cargill administra suas operações. É um terminal Rodo-Ferro-Hidroviário com grande potencial de produção. Têm como acessos as rodovias BR-262, BR-264 e SP-300, a hidrovia do rio Paraná (PK 2630) e a ferrovia Novoeste que se interliga com o porto de Santos. Sua área de influência estende-se do leste do Mato Grosso do Sul a Noroeste de São Paulo. Possui armazéns com capacidade para 20 mil toneladas de granéis sólidos e 7,5 toneladas de granéis líquidos, sendo a soja, o farelo de soja e o óleo de soja as principais mercadorias movimentadas (ANTAQ, 2006).

\section{a.3 - Porto de São Simão (Rio Paranaíba - GO)}


O complexo portuário de São Simão está localizado no extremo norte da hidrovia Tietê-Paraná, tendo como acesso a rodovia BR 364.

Este porto é composto por quatro terminais privados: Caramuru, ADM, Coinbra e Nova Roseira, todos eles especializados no armazenamento e embarque de granéis, principalmente soja (AHRANA, 2006).

\section{a.4 - Porto de Bataguassu (Rio Paraná - MS)}

Está localizado na margem direita do rio Pardo a aproximadamente $30 \mathrm{~km}$ do Rio Paraná. Têm como área de influência a própria região e o pólo agrícola de Dourados, que está à distância de $300 \mathrm{~km}$. Com uma área construída de aproximadamente $3.800 \mathrm{~m}^{2}$, o terminal possui um armazém com capacidade para 12 mil toneladas de grãos, equipados com correia transportadora com capacidade para movimentar 200 toneladas/horas, moega para 200 toneladas/horas e balança para 80 toneladas (AGITRANS, 2006).

\section{b - Hidrovia Paraguai-Paraná}

\section{b.1 - Porto de Corumbá (MS)}

Está situado na margem direita do rio Paraguai, $\mathrm{km} \mathrm{1.528,8.} \mathrm{Possui} \mathrm{cais} \mathrm{em}$ plataforma com 202 m de extensão. Atualmente, conforme convênio 13/98 celebrado pela União por intermédio do Ministério dos Transportes e 0 Município de Corumbá, o porto foi cedido à Prefeitura Municipal para sua administração e exploração, sendo esse porto utilizado pelas empresas de Turismo da região para a movimentação de passageiros e pequenos volumes de carga (AHIPAR, 2006).

\section{b.2 - Porto da Sobramil - Corumbá (MS)}

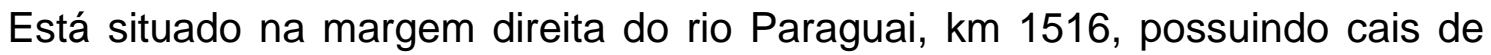
paramento vertical para atracação, com sistema complementar de dolfins para movimentação das embarcações e esteira graneleira para embarque com capacidade de 1 mil toneladas/h (AHIPAR, 2006). A capacidade estática total é de 20 mil toneladas. As suas principais cargas movimentadas são minérios de ferro e manganês granulados.

\section{b.3 - Porto de Ladário - Ladário (MS)}




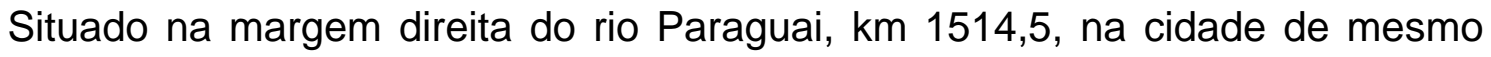
nome, este terminal é administrado pela AHIPAR, ligado ao Ministério do Transportes, porém o mesmo encontra-se inativo. Há um interesse pelo governo do estado de Mato Grosso do Sul que o porto passe para seu controle, visando sua reativação por meio de concessão à iniciativa privada.

Possui dois berços de atracação tipo "dolfins", sendo um para movimentação de sacaria através de correia transportadora reversível com capacidade nominal de 60 toneladas/h e outro para a movimentação de granéis sólidos (minérios), também por correia transportadora com capacidade de 500 toneladas/h.

Além desses, possui um berço para movimentação de carga geral, equipado com guindaste fixo tipo "grua", com capacidade de 1,2 toneladas na ponta da lança de $40 \mathrm{~m}$.

O retro-porto é constituído por um pátio para estocagem de minérios com capacidade para 40 mil toneladas, pátio para carga geral, um armazém convencional para armazenagem de sacaria (capacidade estática de 4 mil toneladas) e currais para movimentação de bovinos com espaço para 1 mil reses.

As principais cargas movimentadas são minérios de ferro e manganês, ferrosílico-manganês, dormentes, reses e em pequena escala, carga geral (AHIPAR, 2006).

\section{b.4 - Porto da Granel Química - Ladário (MS)}

O terminal está localizado na fronteira com a Bolívia, na cidade de Ladário, no quilômetro 2.763 da Hidrovia Paraguai-Paraná. Com um calado nunca abaixo de 3 metros, o terminal tem uma capacidade de armazenagem de 48 mil toneladas de grãos em 6 compartimentos segregados, além de 2 moegas rodoferroviárias e 2 berços de atracação. É um terminal de transbordo principalmente para exportações de soja da Bolívia e do Brasil e importações de trigo da Argentina para o Brasil e Bolívia. O terminal é também utilizado como transbordo de açúcar, milho, arroz e outras cargas transportadas na hidrovia. 
Por ser multimodal, o terminal opera tanto na descarga e carregamento de vagões, através de uma ferrovia que liga Santos a Santa Cruz de La Sierra na Bolívia, como também de caminhões e barcaças fluviais. O terminal conta ainda com 3 balanças, uma para caminhões e vagões com capacidade de até 160 toneladas e outras 2 balanças de fluxo. Pode-se descarregar 3 vagões ao mesmo tempo a 200 toneladas/h cada, a mesma velocidade de descarga de barcaças. Utilizando-se os dois berços simultaneamente, as barcaças podem ser carregadas a 1 mil toneladas $/ \mathrm{h}$.

Sendo um terminal alfandegado, permite o desembaraço aduaneiro para cargas provenientes de exportação ou importação.

O terminal possui também 20 mil $\mathrm{m}^{2}$ de área alfandegada para armazenagem em local aberto e outra área reservada para um futuro terminal de líquidos (GRANEL, 2006).

\section{b.5 - Porto Gregório Curvo / Porto Esperança - Corumbá (MS)}

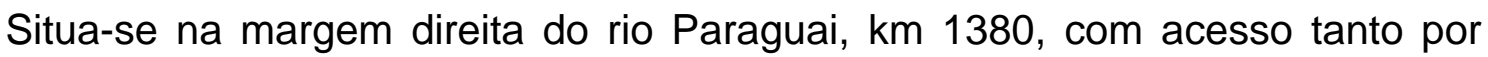
rodovia como pela ferrovia Novoeste, este terminal possui capacidade estática total de 50 mil toneladas e cais de aproximadamente 140 metros pertencente à RTZ/Mineração Corumbaense Reunida S.A (AHIPAR, 2006).

As principais cargas movimentadas são manganês e ferro granulado. Para o embarque dessas cargas possui esteira de minério com capacidade aproximada de 900 toneladas/h, com sistema de movimentação de minério no retro-porto através de correias transportadoras instaladas com túneis enterrados.

\section{b.6 - Porto de Porto Murtinho - Porto Murtinho (MS)}

Situado na margem esquerda do rio Paraguai, $\mathrm{Km} \mathrm{996,} \mathrm{pertencente} \mathrm{ao}$ Governo Estadual, se encontra em concessão pela Agência Portuária de Porto Murtinho. Tem sua influência na movimentação de cargas das regiões de Dourados, Campo Grande e próprio Porto Murtinho. Possui armazéns graneleiros com capacidade de estocagem para 30 mil toneladas, correia transportadora (reversível) com capacidade para movimentar 650 toneladas/horas, balança para 80 toneladas e escritório com alfândega. As 
principais cargas ali movimentadas são grãos, cimento e açúcar oriundos principalmente da região sudoeste do estado, que tem como único acesso a BR 267 (CINCONAV, 2006).

\subsubsection{Portos Marítimos}

\section{a - Porto de Paranaguá}

O porto é administrado pela autarquia estadual Administração dos Portos de Paranaguá e Antonina (APPA). Está localizado na cidade de Paranaguá, no estado do Paraná, na margem sul da baía de Paranaguá. Sua área de influência compreende o estado do Paraná e parte dos estados de São Paulo, Santa Catarina, Rio Grande do Sul e Mato Grosso do Sul. Inclui também o Paraguai, que dispõe de um entreposto franco no porto (PORTOSDOPARANA, 2006).

Situação Atual:

O porto de Paranaguá (PR), que já respondeu pelo embarque de mais de $60 \%$ da soja e farelo exportados pelo Brasil, perde carga para outros terminais com a ampliação geográfica da produção. Em 2000, a participação do porto paranaense, nos embarques de soja, caiu para 40\%. Como resultado da expansão da cultura da soja no centro-oeste e no norte, o embarque de soja dobrou no porto fluvial de Itacoatiara (AM) e cresceu também em São Luís (MA).

\section{Acessos:}

- RODOVIÁRIO - Pela BR-277, ligando Paranaguá a Curitiba e conectando a BR-116 pelas rodovias PR-408, PR-411 e PR-410.

- FERROVIÁRIO - Pela Ferrovia Sul-Atlântico S/A, malha Sul, da antiga Superintendência Regional Curitiba (SR 5), da Rede Ferroviária Federal S.A. (RFFSA).

- MARÍTIMO - A barra de entrada tem largura de 200 m e profundidade de $12 \mathrm{~m}$. O porto possui três canais de acesso: o do norte, o do sudeste e o da Galheta, esse último, o principal, com 28,5 km de extensão, largura variando de $150 \mathrm{~m}$ a $200 \mathrm{~m}$ e profundidade de $12 \mathrm{~m}$. 
Suas instalações são compostas de um cais comercial e um píer de inflamáveis, somando $2.800 \mathrm{~m}$ de comprimento. O cais comercial, com $2.616 \mathrm{~m}$ e 12 berços, de profundidades variando de $6 \mathrm{~m}, 8 \mathrm{~m}$ e $12 \mathrm{~m}$, é atendido por 28 armazéns (sendo cinco arrendados, um servindo de garagem, entre um de escritório para o porto e um de entreposto do Paraguai) com um total de 75.660 $\mathrm{m}^{2}$, dos quais $50.160 \mathrm{~m}^{2} \mathrm{e}$ dois galpões, reunindo $3.570 \mathrm{~m}^{2}$, atendem à movimentação de carga geral.

As instalações contam com três silos verticais para grãos, dispondo de 120 mil toneladas de capacidade global, além de 12 silos horizontais para grãos e farelos, que incorporam a capacidade de 314 mil toneladas. Possui, também, seis pátios descobertos, com área total de $56.250 \mathrm{~m}^{2}$, sendo três para contêineres e os demais para equipamentos, materiais pesados e diversos, bem como 48 tanques para derivados de petróleo e óleos vegetais, formando 212 toneladas de capacidade. Existem, ainda, outros três silos verticais, de uso privativo permitindo a armazenagem de 66 mil toneladas de grãos, e 10 silos horizontais, para grãos e farelos, nesse caso atingindo 489 mil toneladas (ANTAQ, 2006).

A tancagem de uso privativo compreende 47 tanques para óleos vegetais e ácidos, perfazendo a capacidade de 87 mil toneladas $O$ terminal de uso privativo, da empresa Cattalini, opera em $488 \mathrm{~m}$ de cais, constituindo dois berços, um com $10 \mathrm{~m}$ e o outro com $12 \mathrm{~m}$ de profundidade (ANTAQ, 2006).

\section{b - Porto de Santos}

O porto é administrado pela Companhia Docas do Estado de São Paulo (Codesp). Está localizado no centro do litoral do estado de São Paulo, estendendo-se ao longo de um estuário limitado pelas ilhas de São Vicente e de Santo Amaro, distante $2 \mathrm{~km}$ do oceano Atlântico. Sua área de influência compreende o estado de São Paulo e grande parte de Mato Grosso do Sul, Mato Grosso, Goiás, Minas Gerais e Paraná.

Acessos:

- RODOVIÁRIO - Pelas SP-055 (Rodovia Padre Manoel da Nóbrega), SP150 (via Anchieta) e SP-160 (Rodovia dos Imigrantes). 
- FERROVIÁRIO - Pela Ferrovia Centro-Atlântica S/A, malha Centro-Leste, da antiga Superintendência Regional São Paulo (SR 7), da Rede Ferroviária Federal S.A. (RFFSA) e pela Unidade Regional Santos (UR 7), da Ferrovias Paulistas S.A. (FEPASA).

- MARÍTIMO - O acesso é franco, contendo um canal com largura de $130 \mathrm{~m}$ e profundidade de $13 \mathrm{~m}$, na parte marítima da baía de Santos, e, no estuário, largura de $100 \mathrm{~m}$ e profundidade de $12 \mathrm{~m}$.

Instalações:

Cais acostável: 11.042 m de extensão e profundidades variando entre 6,6 m e $13,5 \mathrm{~m} ; 521 \mathrm{~m}$ de cais para fins especiais, com profundidade mínima de $5 \mathrm{~m}$, e $1.883 \mathrm{~m}$ para uso privativo, com profundidades de $5 \mathrm{~m}$ a $11 \mathrm{~m}$.

A armazenagem é atendida por 45 armazéns internos, sendo 34 na margem direita e 11 na margem esquerda do estuário e 39 armazéns externos. Esse conjunto perfaz $516.761 \mathrm{~m}^{2}$, com uma capacidade estática de 416 mil toneladas. Existe, ainda, um frigorífico com $7.070 \mathrm{~m}^{2}$, e capacidade estática de 4 mil toneladas. O porto dispõe de 33 pátios de estocagem, internos e externos, somando $124.049 \mathrm{~m}^{2}$, com capacidade estática de 99 mil toneladas.

Para contêineres são utilizados quatro pátios: um no Saboó para 1 mil TEU, outro junto ao Armazém XXXVI para 800 TEU, um terceiro, ao lado do Moinho Pacífico, comportando 450 TEU e o do Terminal de Contêineres (Tecon), com suporte para 6.700 TEU.

As instalações de tancagem compreendem: na llha do Barnabé, 39 tanques para $150 \mathrm{mil} \mathrm{m}^{3}$ e 131 para $112 \mathrm{mil} \mathrm{m}^{3}$; no Cais do Saboó, 24 para 2,7 mil m³ e 28 para $14 \mathrm{mil} \mathrm{m}^{3}$; no terminal do Alemoa, 10 tanques totalizam $105 \mathrm{mil} \mathrm{m}^{3}$ e 50 somam $390 \mathrm{mil} \mathrm{m}^{3}$.

Terminais especializados:

$\checkmark$ Tecon: terminal para contêineres localizado na margem esquerda do porto, com área de $350 \mathrm{mil} \mathrm{m}^{2}$, cais de $510 \mathrm{~m}$ e profundidade de $13 \mathrm{~m}$. Permite atracação simultânea de três navios. Conta com três armazéns representando $1.530 \mathrm{~m}^{2}$ e pátios com o total de $198.450 \mathrm{~m}^{2}$, podendo operar 140 mil TEU por ano. 
$\checkmark$ Tefer: terminal para fertilizantes, também na margem esquerda, utiliza um cais de $567 \mathrm{~m}$ com dois píeres acostáveis de $283,5 \mathrm{~m}$ e profundidade de $17,5 \mathrm{~m}$. Possui seis armazéns com capacidade para 30 mil toneladas cada um.

$\checkmark$ Carvão: instalado no Saboó, tem área de $10.800 \mathrm{~m}^{2}$ e capacidade para 50 mil toneladas.

$\checkmark$ Granéis líquidos: no Alemoa, na margem direita do estuário, com um cais de $631 \mathrm{~m}$ e profundidade de $11 \mathrm{~m}$. Está ligado à llha do Barnabé, na margem esquerda - com $341 \mathrm{~m}$ de cais e $10 \mathrm{~m}$ de profundidade -, por meio de dois dutos submarinos.

$\checkmark$ Ro-ro: o porto oferece seis berços, sendo dois no Saboó, dois junto ao pátio do armazém 35 , um no cais do armazém 29, e um no cais do futuro armazém 37.

\section{c - Porto de Nueva Palmira - Uruguai}

Compreende, em seu conjunto, o porto administrado pela Administração Nacional de Portos - ANP, o terminal e porto privado de CORPORACION NAVíoS S.A. e as instalações da FRIGOFRUT, todos componentes da Zona Franca de Nueva Palmira.

O recinto portuário possui silos para armazenagem de granéis agrícolas com uma capacidade global da ordem de 72 mil toneladas, administrados pelo consórcio TERMINALES GRANELERAS URUGUAYAS S.A. - TGU. Entre os equipamentos, destaca-se um carregador de grãos ligado por correias transportadoras ao cais portuário.

Os principais produtos movimentados, atualmente, são cereais, frutas cítricas, granéis sólidos, madeiras e seus derivados e mercadorias em trânsito.

Nueva Palmira se encontra no km 0 da hidrovia Paraná-Paraguai que, somado às facilidades de contar com uma zona franca e condições de acessibilidade fluvial desde o Rio da Prata e do canal Martin Garcia, se convertem em um porto de grande importância para o escoamento dos produtos da hidrovia Paraguai-Paraná. 
Possui calado de acesso de 10 metros e calado interno de 5 metros. Somamse à sua estrutura correias transportadoras de grãos e silos de grãos com capacidade de 72 mil toneladas (ANP, 2006). 


\section{DELIMITAÇÃO DO PROBLEMA}

Os dados de produção das cargas transportadas, tecnologias de transportes utilizadas, valores de fretes e transbordos e configuração do cenário dentro do SIG - TransCAD são apresentados a seguir.

\subsection{PRODUTOS DE EXPORTAÇÃO CONSIDERADOS}

Os produtos que fazem parte do estudo logístico são: a soja, por representar o cereal mais produzido no estado, e o minério de ferro e manganês, já que o estado possui uma das maiores jazidas do país.

A produção destes produtos é representada de forma regionalizada, com a soma de vários pólos de produção de uma grande região, uma vez que os principais pólos de produção têm influência sobre os demais que estão no entorno.

\subsubsection{Soja}

Hoje, no Mato Grosso do Sul, mais de $80 \%$ de seus municípios produzem soja. Para efeito de estudo são consideradas as três maiores regiões produtoras, segundo dados do IBGE.

As três regiões estudadas são a Norte com pólo em Chapadão do Sul, a Central, com pólo em Campo Grande, e a Sul, com pólo em Dourados, todas ilustradas na Figura 5.1. Nestas condições, as distâncias dos produtos até os portos de exportação são calculadas em relação aos pólos de cada região para o modal rodoviário. Já para o modal ferroviário e hidroviário, quando estes são os únicos utilizados ou quando for o primeiro modal da cadeia de transporte, é considerada uma distância pelo modal rodoviário (ponta rodoviária), através da média ponderada entre a distância rodoviária da cidade produtora até $\mathrm{o}$ 
terminal de transbordo que será utilizado para região e a quantidade de produtos gerados por esta cidade. Estes valores são apresentados na terceira coluna (Média km) das tabelas 5.1, 5.2 e 5.3. 


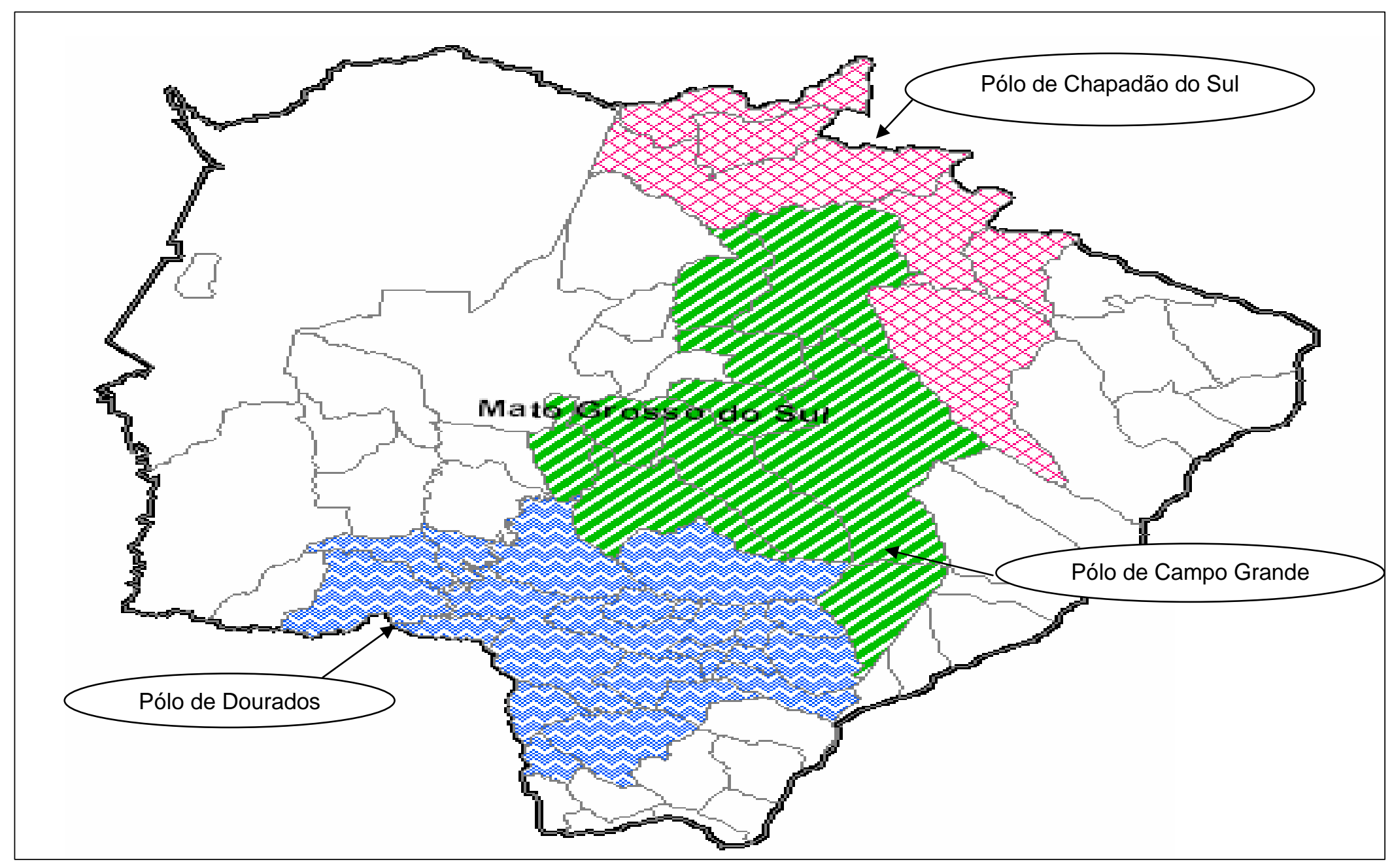

Figura 5.1 - Pólos de produção de soja em Mato Grosso do Sul Fonte: Elaborado pelo autor 


\section{a - Região Norte}

Com pólo em Chapadão do Sul, esta região engloba os seguintes municípios:

Tabela 5.1 - Produção municipal da região Norte no ano de 2000

\begin{tabular}{lcc}
\hline \multicolumn{1}{c}{ MUNICÍPIO } & QUANTIDADE (T) & MÉDIA (km) \\
\hline Água Clara & 61.000 & 482 \\
\hline Chapadão do Sul & 179.300 & 0 \\
\hline Costa Rica & 147.200 & 188 \\
\hline Alcinópolis & 15.700 & 500 \\
\hline Pedro Gomes & 5.600 & 940 \\
\hline Sonora & 124.300 & 838 \\
\hline Coxim & 31.400 & 776 \\
\hline TOTAL & $\mathbf{5 6 4 . 5 0 0}$ & $\mathbf{3 5 2}$ \\
\hline & Fonte: IBGE &
\end{tabular}

\section{b - Região Central}

Centrado em Campo Grande, este pólo representa os seguintes municípios:

Tabela 5.2 - Produção municipal da região Central no ano de 2000

\begin{tabular}{lcc}
\hline \multicolumn{1}{c}{ MUNICÍPIO } & QUANTIDADE (T) & MÉDIA (km) \\
\hline Bandeirantes & 17.900 & 144 \\
\hline Camapuã & 13.600 & 272 \\
\hline Campo Grande & 3.900 & 0 \\
\hline Dois Irmãos do Buriti & 1.000 & 194 \\
\hline Jaraguarí & 5.600 & 98 \\
\hline Nova Alvorada do Sul & 23.900 & 240 \\
\hline Nova Andradina & 2.700 & 618 \\
\hline Ribas do Rio Pardo & 17.900 & 204 \\
\hline São Gabriel do Oeste & 246.600 & 280 \\
\hline Sidrolândia & 85.200 & 150 \\
\hline Terenos & 6.000 & 62 \\
\hline TOTAL & $\mathbf{4 2 4 . 3 0 0}$ & $\mathbf{2 3 6}$ \\
\hline
\end{tabular}

Fonte: IBGE 


\section{c - Região Sul}

Tendo como pólo principal a cidade de Dourados, a região Sul é composta pelos seguintes municípios:

Tabela 5.3 - Produção municipal da região Sul no ano de 2000

\begin{tabular}{|c|c|c|}
\hline MUNICÍPIO & QUANTIDADE (T) & MÉDIA (km) \\
\hline Amambaí & 25.600 & 428 \\
\hline Angélica & 5.400 & 486 \\
\hline Antônio João & 17.900 & 302 \\
\hline Aral Moreira & 119.400. & 406 \\
\hline Bela Vista & 16.600 & 406 \\
\hline Caarapó & 97.600 & 280 \\
\hline Coronel Sapucaia & 5.800 & 488 \\
\hline Deodápolis & 3.500 & 342 \\
\hline Douradina & 16.100 & 208 \\
\hline Dourados & 228.300 & 176 \\
\hline Fátima do Sul & 11.900 & 262 \\
\hline Glória de Dourados & 1.500 & 338 \\
\hline Guia Lopes da Laguna & 6.300 & 240 \\
\hline Itaporã & 91.500 & 142 \\
\hline Ivinhema & 600 & 422 \\
\hline$\overline{\text { Jardim }}$ & 5.600 & 248 \\
\hline Jateí & 5.000 & 316 \\
\hline Juti & 4.500 & 344 \\
\hline Laguna Carapã & 74.000 & 280 \\
\hline Maracajú & 179.400 & 0 \\
\hline Ponta Porá & 213.000 & 304 \\
\hline Rio Brilhante & 112.100 & 162 \\
\hline Vicentina & 6.500 & 282 \\
\hline TOTAL & 1.248 .100 & 222 \\
\hline
\end{tabular}

Fonte: IBGE

\subsubsection{Minério de Ferro e Manganês}

A partir de 1995 a exploração mineral em Mato Grosso do Sul ganhou relevância no contexto nacional, devido a Companhia Vale do Rio Doce tornase a única proprietária da Urucum Mineração. Antes da aquisição a exploração mineral sul-mato-grossense ficou em segundo plano no interesse das grandes empresas mineradoras. Estas optavam pela exploração em minas localizadas mais próximas dos principais mercados consumidores (LAMOSO, 2001).

As jazidas estão situadas nos municípios de Corumbá e Ladário (Figura 5.2), próximas a fronteira Brasil-Bolívia, compondo a formação da serra do Rabicho, Morro Grande, Serra de Santa Cruz, Morro de Tromba dos Macacos, Serra do Jacadigo e do Morro do Urucum. Na topografia da planície do rio Paraguai 
destacam-se essas formações que são popularmente conhecidas como "Morraria do Urucum" (DNPM, 2006) .

Segundo o Departamento Nacional de Produção Mineral (DNPM) as formações concentram 248,6 milhões de toneladas de manganês com grau de pureza entre $45 \%$ e $52 \%$, o maior do mundo em volume, perdendo apenas para as jazidas da Ucrânia. Além disso, concentra outras 912 milhões de toneladas de ferro (DNPM, 2006).

Também para este pólo é considerada, quando o primeiro ou o único modal a ser utilizado for o ferroviário ou hidroviário, a distância de $60 \mathrm{~km}$ referente à ponta rodoviária da mina de extração até o ponto de embarque em Corumbá. 


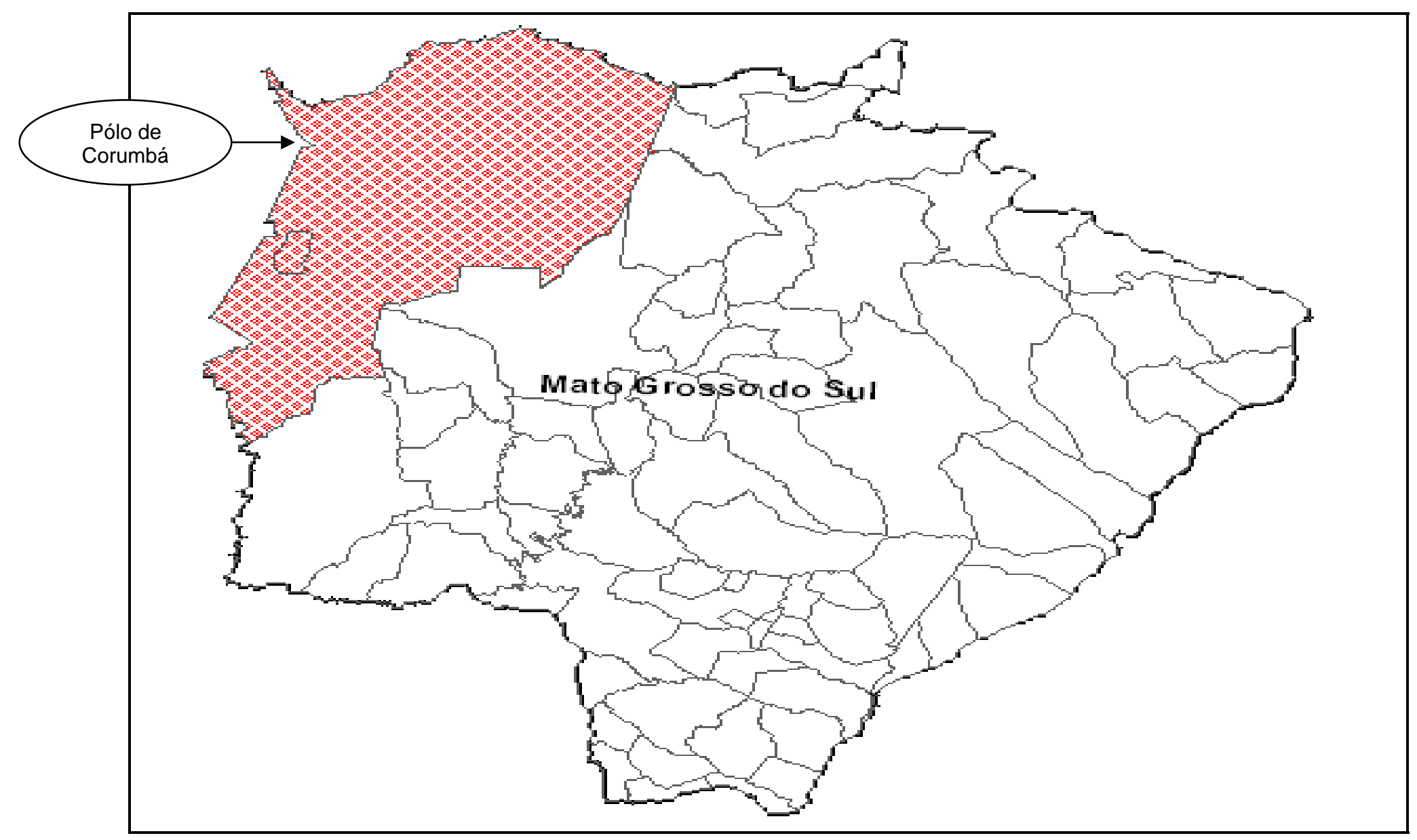

Figura 5.2 - Pólo de produção de minérios em Mato Grosso do Sul Fonte: Elaborado pelo autor 


\subsection{COMPOSIÇÃO DOS CUSTOS DE TRANSPORTES}

Pode-se dividir o custo de transporte, basicamente em duas partes: custo de transporte e custo de terminal (transferência de produtos). De acordo com WRIGHT (1980), o custo de transporte esta associado à distância percorrida e inclui o custo de capital, combustível, lubrificantes, manutenção, depreciação dos equipamentos e mão-de-obra. Já a segunda parte refere-se às operações de recepção, armazenagem e expedição da carga transportada.

Para apresentar custos adequados ao transporte, a escolha da tecnologia de transporte utilizada é de extrema importância para a proporcionalidade entre custos fixos e variáveis.

MICHAELS et al. (1982) e BEILOCK e CASAVANT (1984) destacam que a intensidade da utilização dos equipamentos de transporte possui grande influência sobre os custos. BEILOCK e CASAVANT (1984) chamam atenção para a freqüência de movimentação e a porcentagem de quilômetros percorridos com o veículo carregado, sendo que este último esta diretamente relacionada com oferta de cargas de retorno.

Outro aspecto, que influencia os custos, é o volume transportado. Uma vez que para o cálculo do custo fixo realiza-se uma estimativa do volume total a ser transportado durante determinado período. Desta forma, as alterações na demanda por transporte modificam os custos fixos unitários de cada modalidade de transporte.

Segundo MICHAELS et al. (1982), o transporte rodoviário possui uma capacidade de adaptar-se mais facilmente às variações da demanda, uma vez que as empresas que atuam no modal rodoviário podem entrar ou sair da atividade em uma região, dando ao custo fixo maior estabilidade em relação à alteração de volume. Em contra partida, as modalidades hidroviária e ferroviária não possuem esta flexibilidade de adaptação as alterações dos volumes transportados, resultando em variações de custo fixo por unidade transportada.

SAMUELSON (1977) conclui que a formação dos preços de transporte seguem as seguintes regras: 
a) as tarifas de transporte tendem a aumentar com o valor unitário da mercadoria transportada;

b) as mercadorias que apresentam uma elasticidade maior de oferta ou de demanda tendem a pagar menores tarifas de transporte;

c) as estruturas de mercado da oferta e da demanda do bem transportado têm efeito sobre as tarifas de transporte pagas pelo bem, e

d) as tarifas de transporte, quanto mais próximas de uma estrutura de mercado de concorrência perfeita, mais se aproximarão dos custos marginais de produção.

Com base nos componentes teóricos sobre os fatores que influem nos custos de transportes, são apresentadas as características e os custos dos veículostipo empregados nos modais rodoviário, hidroviário e ferroviário, além dos custos de transbordos para a movimentação dos produtos considerados no estudo com destino à exportação.

O mesmo custo de transporte é utilizado tanto para a movimentação de soja quanto para o de minério.

Na prática, o valor do frete para o transporte de minério é ligeiramente menor que para o transporte da soja, sendo esta diferença praticada principalmente nos modais ferroviário e hidroviário. Isto ocorre, porque os equipamentos utilizados no transporte de minérios possuem um custo de capital menor e o produto não necessita de cuidados contra as ações do tempo.

\subsubsection{Modal rodoviário}

Neste modal, é utilizado como veículo padrão para o estudo um bitrem graneleiro de sete eixos (3S2B2) (Figura 5.3). Este conjunto é composto de um cavalo mecânico de três eixos SCANIA 6X2 420, mais dois semi-reboques graneleiros de dois eixos cada, com comprimento de 19,80 metros e 40 toneladas de carga. O veículo será utilizado na investigação tanto para o transporte de grãos quanto para minérios. 


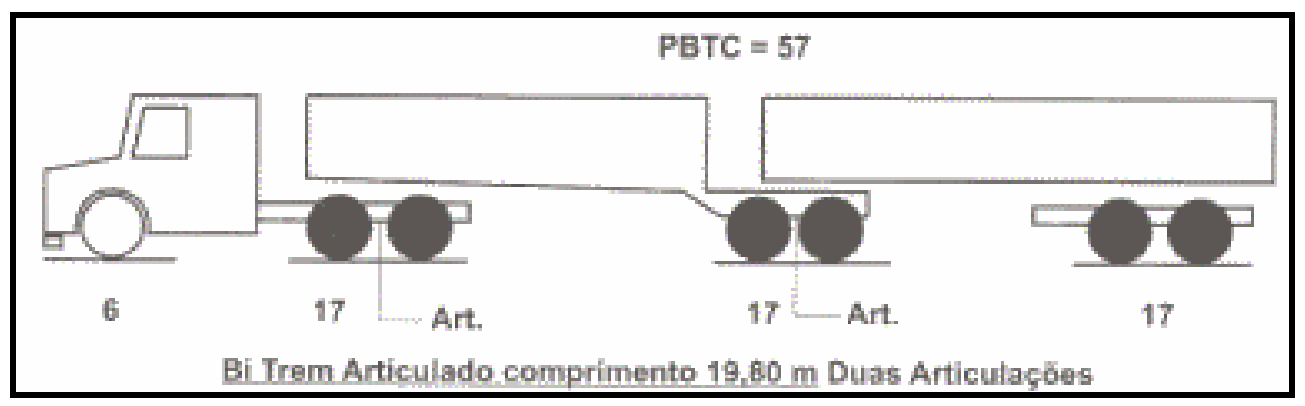

Figura 5.3 - Bitrem de 7 eixos

Fonte: DNIT, 2006

Para calcular os custos operacionais do modal rodoviário, TIAGO (2002), RORATO (2003) e SILVA (2005) utilizaram em seu trabalho o método baseado na segregação de custos, proposto por VALENTE et al. (1997) e KAWAMOTO (1999), onde os custos são divididos em custo fixos e variáveis. Neste trabalho foi adotado o método contido no "Manual de Cálculo de Custos e Formação de Preços do Transporte Rodoviário de Cargas" publicado pela NTC, 2006 (Associação Nacional do Transporte de Cargas), onde também os custos são divididos em fixos e variáveis, porém com mais itens analisados.

O custo encontrado para este modal é de $\mathrm{R} \$ 2,37$ por quilometro rodado, sendo que a planilha contendo todas as variáveis encontra-se no Apêndice A.

\subsubsection{Modal hidroviário}

Neste modal, são utilizados dois tipos de comboios fluviais (conjunto de empurrador mais barcaças); um típico utilizado na hidrovia Tietê-Paraná e outro típico da hidrovia Paraguai-Paraná.

A bibliografia analisada para estruturar a formação de custos de transporte fluvial é de certa forma extensa, porém os modelos utilizados não fogem da mesma estrutura de análise. Para esta investigação foram analisados os métodos descritos a seguir, resultando em um modelo de cálculo de custos.

PIRES JR. (1989) trabalhou com o custo total do navio dividido em três parcelas: custo de capital, custo operacional e custo de viagem. O custo de capital se refere aos encargos relativos à propriedade da embarcação. O custo operacional abrange todas as despesas para manter a embarcação disponível 
para operar e o custo de viagem se refere aos custos oriundos da embarcação estar navegando.

Para NOVAES (1976), grande parte dos custos operacionais do navio podem ser considerados fixos independente da quantidade de carga transportada ou do fato de estar navegando ou não. Desta forma, é muito utilizado o cálculo do custo médio diário para as situações da embarcação navegando e a embarcação parada no porto.

Devido aos altos custos envolvidos no transporte hidroviário, não é indicado considerar o custo de um frete hidroviário apenas baseado nos métodos propostos, haja visto que a mobilidade e a flexibilidade dos veículos hidroviários em adaptar-se aos diversos tipos de carga a transportar são de certa forma bem mais complexas que as do modal rodoviário e ferroviário, além de que, para a viabilidade deste modal, o grande volume a ser transportado e a consolidação de um pólo gerador e outro receptor de carga são alguns dos fatores condicionantes.

Em virtude de esta investigação considerar um volume que justifique o investimento no modal hidroviário, o trabalho adota para o cálculo do frete 0 modelo proposto por NOVAES (1976). Porém, algumas modificações foram introduzidas, devido à diferença do tipo carga e também do tipo de embarcações utilizadas.

Os parâmetros de entrada considerados no modelo e os respectivos valores adotados neste trabalho foram obtidos, no ano de 2006, junto às empresas Cinconav (atual Fluviomar), Empresa Torque de Navegação e Estaleiro Wilson Sons.

\section{1 - Embarcação Tietê-Paraná}

Inicialmente, a capacidade de carga admitida para os comboios-tipo desta hidrovia eram: Tietê 2.400 toneladas e Paraná 4.800 toneladas (AHRANA, 2006). Tal fato se deve principalmente às dimensões que as câmaras das eclusas impõem ao tráfego dos comboios, além das câmaras das eclusas no rio Tietê possuírem uma dimensão menor que as da eclusa do rio Paraná. 
Devido às restrições físicas impostas por estas obras de engenharia existentes nas vias navegáveis do Tietê e do Paraná, a Diretoria de Portos e Costas autoriza através do ofício no 1687 de 16 de dezembro de 2004, conforme ofício no 717 de 25 de abril 2005 da Capitania Fluvial do Tietê-Paraná, as seguintes dimensões máximas permissíveis para os comboios (MARINHA DO BRASIL, 2006):

I - Comboio Tipo Tietê: formado por grupo de chatas em linha mais 01 (um) empurrador.

\begin{tabular}{ccc}
\hline Comprimento Total & Boca & Calado \\
\hline $137 \mathrm{~m}$ & $11 \mathrm{~m}$ & $2,70 \mathrm{~m}$ \\
\hline
\end{tabular}

II - Comboio Tipo Tietê-Duplo: formado por grupo de chatas em linha, lado a lado, mais um empurrador.

\begin{tabular}{ccc}
\hline Comprimento Total & Boca & Calado \\
\hline $137 \mathrm{~m}$ & $22 \mathrm{~m}$ & $2,70 \mathrm{~m}$ \\
\hline
\end{tabular}

III - Comboio Tipo Paraná: formado por grupo de chatas em linha, lado a lado mais um empurrador.

\begin{tabular}{ccc}
\hline Comprimento Total & Boca & Calado \\
\hline $200,50 \mathrm{~m}$ & $16 \mathrm{~m}$ & $3,70 \mathrm{~m}$ \\
\hline
\end{tabular}

IV - Comboio Tipo Paraná Estendido: formado por grupo de chatas em linha e lado a lado, mais um empurrador.

\begin{tabular}{ccc}
\hline Comprimento Total & Boca & Calado \\
\hline $257,50 \mathrm{~m}$ & $22 \mathrm{~m}$ & $3,70 \mathrm{~m}$ \\
\hline
\end{tabular}

Apesar das câmaras das eclusas do Rio Tietê serem menores que a do Rio Paraná, o trabalho adota um comboio constituído de 4 barcaças com capacidade de mil toneladas de carga cada uma, totalizando assim 4 mil toneladas. Dessa forma, é necessária a realização de desmembramento na passagem das eclusas e em algumas pontes. 
A adoção do Comboio tipo Tietê Duplo, justifica-se pelo fato desta configuração estar sendo utilizada por grande parte das empresas de navegação que operam na hidrovia Tietê-Paraná.

$\mathrm{Na}$ Tabela 5.4 são apresentadas as características da embarcação tipo utilizada na investigação e na Figura 5.4 são ilustrados esses comboios.

Tabela 5.4 - Características do comboio Tietê-Paraná adotado para estudo

\begin{tabular}{lccccc}
\hline $\begin{array}{c}\text { Tipo de } \\
\text { embarcação }\end{array}$ & $\begin{array}{c}\text { Comprimento } \\
\text { (Metros) }\end{array}$ & $\begin{array}{c}\text { Boca } \\
\text { (Metros) }\end{array}$ & $\begin{array}{c}\text { Calado } \\
\text { Máximo }\end{array}$ & $\begin{array}{c}\text { Potência } \\
\text { (HP) }\end{array}$ & $\begin{array}{c}\text { Capacidade } \\
\text { (Toneladas) }\end{array}$ \\
\hline Empurrador (1) & 17 & 7,5 & $2,5 \mathrm{~m}$ & $2 \times 450$ & \\
\hline Chata (4) & 60 & 11 & $2,5 \mathrm{~m}$ & & 1.000 \\
\hline Comboio & 137 & 22 & $2,5 \mathrm{~m}$ & 900 & 4.000 \\
\hline
\end{tabular}

Fonte: Elaborada pelo autor

O valor do frete para esse comboio tipo é obtido através do método descrito no Capítulo 5.2.2, detalhado no Apêndice $B$, que resulta num valor de $R \$ 3,35$ por tonelada dia, ou $\mathrm{R} \$ 74,46$ por quilômetro navegado.
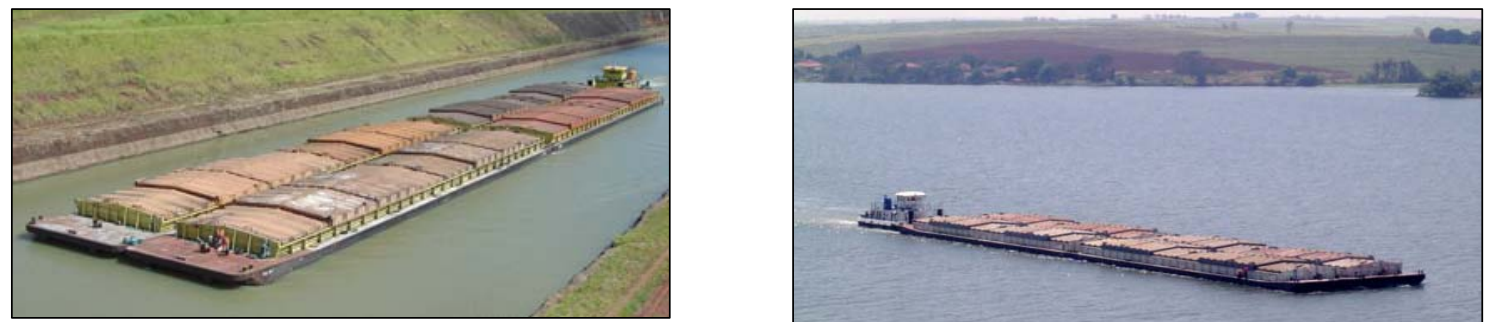

Figura 5.4 - Fotos de Comboio tipo "Tietê Duplo" na hidrovia Tietê-Paraná Fonte: Empresa Paulista de Navegação (EPN) - Grupo Torque

\section{2 - Embarcação Paraguai-Paraná}

Os comboios tipos desta hidrovia possuem maior capacidade de carga, devido as característica do rio e pela inexistência de eclusas, porém em sua operação há a necessidade de desmembramento, em virtude das curvas, passagens estreitas, segurança em pontes e nível baixo do rio, entre outras dificuldades para a navegação.

Nesta hidrovia, atualmente, são utilizados comboios com formação de barcaças de diferentes dimensões. Esta variedade de barcaças e empurradores se deve a diversos fatores, destacando-se: o grande número de barcaças e 
empurradores antigos, afretamento e aquisição de equipamentos de outros países e comboios transportando diversos tipos de produtos, entre outros.

Para este estudo, foi utilizado um comboio composto por um empurrador de $2.500 \mathrm{HP}$ e nove barcaças com capacidade de carga de 2 mil toneladas cada, resultando num comboio de 18 mil toneladas e dimensões totais de 50 metros de largura por 290 metros de comprimento. A escolha dessa configuração de comboio se deve ao cumprimento do Acordo de Transporte Fluvial pela Hidrovia Paraguai - Paraná firmado entre o Brasil, Argentina, Paraguai, Uruguai e Bolívia, o qual estabelece entre outros acordos, comboios no trecho do rio Paraguai com comprimento máximo de 290 metros e largura de 50 metros (MRE, 2006).

$\mathrm{Na}$ Tabela 5.5 são apresentadas as características da embarcação tipo utilizada na investigação e na Figura 5.5 são ilustrados esses comboios.

Tabela 5.5 - Características do comboio Paraguai-Paraná adotado para estudo

\begin{tabular}{lccccc}
\hline $\begin{array}{c}\text { Tipo de } \\
\text { embarcação }\end{array}$ & $\begin{array}{c}\text { Comprimento } \\
\text { (Metros) }\end{array}$ & $\begin{array}{c}\text { Boca } \\
\text { (Metros) }\end{array}$ & $\begin{array}{c}\text { Calado } \\
\text { Máximo }\end{array}$ & $\begin{array}{c}\text { Potência } \\
\text { (HP) }\end{array}$ & $\begin{array}{c}\text { Capacidade } \\
\text { (Toneladas) }\end{array}$ \\
\hline Empurrador (1) & 26 & 16 & $2,5 \mathrm{~m}$ & $2 \times 1.250$ & \\
\hline Chata (9) & 88 & 16,6 & $3,0 \mathrm{~m}$ & & 2.000 \\
\hline Comboio & 290 & 50 & $3,0 \mathrm{~m}$ & 2.500 & 18.000 \\
\hline
\end{tabular}

Fonte: Elaborada pelo autor

Também para esse comboio tipo, o valor da tarifa é obtido através do método proposto no capítulo 5.2.2, detalhado no Apêndice $C$, onde apresenta um valor de $\mathrm{R} \$ 2,03$ por tonelada dia, ou $\mathrm{R} \$ 190,65$ por quilometro navegado.
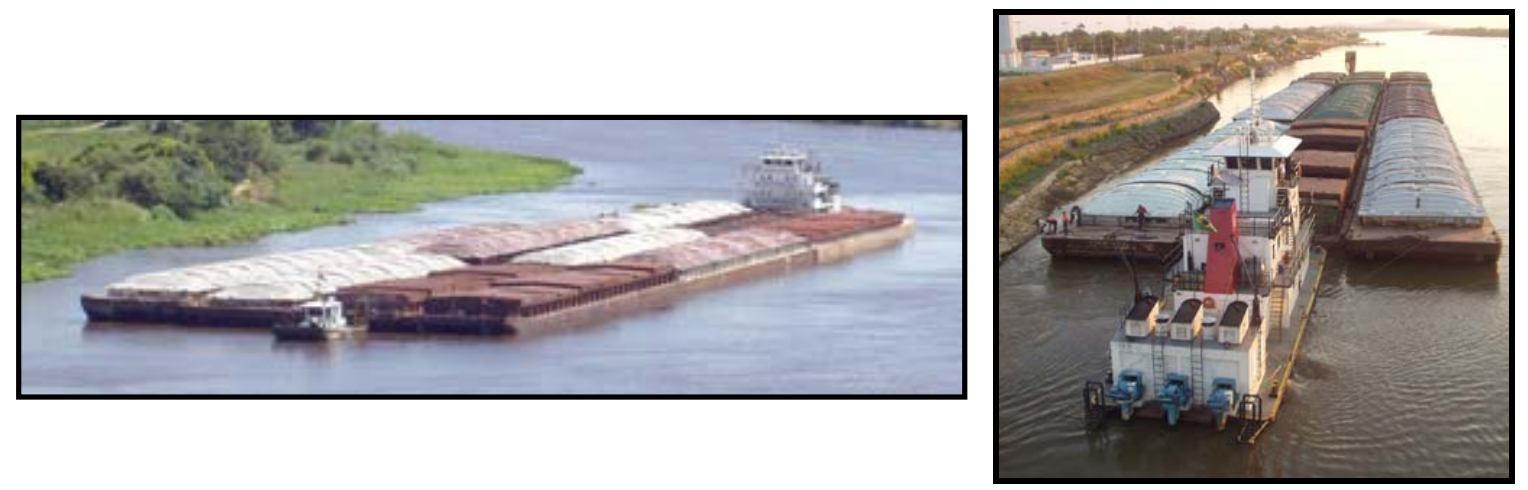

Figura 5.5 - Fotos de comboios-tipo da hidrovia Paraguai-Paraná Fonte: CINCO - Companhia Interamericana de Navegação e Comércio 


\subsubsection{Modal Ferroviário}

Neste modal, o cálculo de fretes não se enquadra na forma convencional utilizada nos outros modais, devido à maneira como este sistema opera. As tarifas variam de acordo com os tipos de carga e principalmente, em função do volume e da distância. Além disso, algumas empresas interessadas em utilizarse da ferrovia possuem vagões próprios, o que faz o valor do frete baixar.

Dentre os principias métodos utilizados para a obtenção do custo de transporte ferroviário, pode-se citar o Modelo Americano e o utilizado no Brasil.

O método Americano obtinha o custo de transporte ferroviário até 1960, através do ICC (Interstate Commerce Comission), onde todas as despesas eram alocadas às unidade de serviço baseado em estudos estatísticos. A partir de 1965, a Union Pacific iniciou um esforço para melhoria de sua apuração de custos através da implantação do COAT (Cost Out All Traffic). O grande mérito do COAT foi a implantação do conceito de custo por movimentação de vagões, onde através da introdução dos dados de origem, destino, toneladas, tipo de vagão, etc, eram determinados os custos ferroviários por viagem. Assim com a introdução do COAT houve uma desagregação dos custos: os custos por tonelada milha passaram a ser baseados no tamanho do movimento (milhas) e no peso do lote embarcado (toneladas).

Buscando melhorar a confiabilidade dos custos ferroviários, foi implantado em 1968 o MCC (Management Cost Control System). Este sistema foi baseado no levantamento e criação de aproximadamente 5.000 centros de custos e em torno de 1.500 códigos de custo, possibilitando o controle de custos de forma mais desagregada e a comparação com valores históricos.

O maior nível de desagregação dos custos foi obtido pela implantação em 1985 do CPMS (Consolidated Profit Measurement System), que estimava o custo e lucro de cada embarque ferroviário. O CPMS era baseado no TUC (Train Unit Cost), onde se desenvolviam custos de composições ferroviárias completas por trecho de operação (COOPER et al.1998, apud RAVARA 2005).

Segundo PIRES (2000), os modelos de obtenção dos valores de custo do transporte utilizado no Brasil, antes da privatização, eram composto por basicamente 4 sistemas distintos: o da Rede Ferroviária Federal S.A. (RFFSA), 
o da Estrada de Ferro Vitória Minas (EFVM), o da Estrada de Ferro Carajás (EFC) e o da Ferrovia Paulista S.A. (FEPASA).

De acordo com TEIXEIRA FILHO (2001), a Rede Ferroviária Federal (RFFSA) realizava o cálculo de seus fretes no período de 1965 a 1996 baseado em três características: tipo de mercadoria, distância percorrida e tonelagem transportada.

Utilizando os dados da FEPASA, MARTINEZ JÚNIOR (1997, apud RAVARA 2005), construiu um sistema para apuração de custos e formação de fretes através de uma metodologia baseada na definição de Centros de Custo, que agregam custos variáveis ao custo total da viagem. Os Centros de Custo são: Estação, Trecho, Locomotiva e Vagão. Para se medir o nível de utilização de cada Centros de Custo, definiu-se os seguintes custos de viagens: Quilômetros percorridos por um trem, tempo de viagem de um trem, quilômetros percorridos por vagão, quilômetros percorridos por locomotiva, tempo de utilização de locomotiva e toneladas quilômetro brutas transportadas.

Através do rateio das despesas incorridas pelos diversos Centros de Custo e o consumo de combustível, chega-se à equação de custo variável de uma viagem:

Custo Viagem = Custos $($ Locomotiva + Vagão + Estações + Via Permanente + Energia)

O trabalho de MARTINEZ JÚNIOR (1997, apud RAVARA, 2005) é baseado em Custeio Direto, sendo função da Margem de Contribuição à cobertura das despesas fixas. Outra observação relevante é que este trabalho não considerou a apropriação dos custos de investimento de capital.

Com o objetivo de construir um método para precificar o frete ferroviário, RAVARA (2005) avaliou diversas metodologias utilizadas pela literatura e pelo mercado, onde constatou que tais metodologias apresentam diversos limitantes na aplicação. Assim, o mesmo custeou o valor do frete ferroviário, através do fluxo de caixa para a operação de um determinado trecho.

Em vista destas características de mensuração dos custos deste modal, resolveu-se adotar um valor de frete por quilômetro baseado nas taxas cobradas pelas operadoras, tais como a FERRONORTE e NOVOESTE, que 
fazem parte da atual ALL - América Latina Logística, e a FERROPAR, já que estas três vias são utilizadas no estudo. Tal adoção é também considerada nos trabalhos de TIAGO (2002), SOUZA et al. (2005), CASTRO (1997) e SILVA (2005).

São considerados neste modal, como pontos de carga, os pátios ferroviários localizados dentro ou próximos dos pólos estudados, devido a esses possuírem infra-estrutura necessária para a operação, além de concentrarem grande volume de produtos para embarque. Desta forma não são considerados embarques em pontos intermediários ao longo das ferrovias utilizadas.

\section{a - ALL - América Latina Logística}

Em contato com a área comercial da ALL foram obtidas informações relativas aos fretes das principais rotas estudadas.

Segundo estas informações, os fretes variam de acordo com o mercado e outras razões já descritas anteriormente; todavia, o mesmo considera para efeito de cálculo desses fretes, a comparação com o modal rodoviário que concorre diretamente com o ferroviário. Para se obter o valor do frete ferroviário, a empresa analisa o frete rodoviário praticado no trecho e assim aplica uma redução em média de $10 \%$, prática esta também considerada por RAVARA (2005), e divulgada pelo Jornal Gazeta Mercantil em 22/04/07, para efeito de competitividade.

Como resultado destas informações recebidas e também através de comparativo com os fretes mensais divulgados pelo Sistema de Informações de Fretes (SIFRECA) do Departamento de Economia. Administração e Sociologia da Escola Superior de Agricultura "Luiz de Queiroz" (ESALQ-USP), são adotados e apresentados os valores nas Tabelas 5.6, 5.7, 5.8 e 5.9.

\section{a.1 - Ferronorte}

Tabela 5.6 - Fatores operacionais da Ferronorte

\begin{tabular}{llccc}
\hline \multicolumn{1}{c}{ Origem } & Destino & $\mathbf{K m}$ & Frete R\$/t & Qtde por composição \\
\hline Chapadão do Sul & Santos & 1.182 & 87,70 & $7.000 \mathrm{t}$ \\
\hline Alto Araguaia & Santos & 1.391 & 96,15 & $7.000 \mathrm{t}$ \\
\hline
\end{tabular}

Fonte: SIFRECA - ESALQ / Ferronorte-ALL (2007) 


\section{a.2 - Novoeste}

Tabela 5.7 - Fatores operacionais da Novoeste

\begin{tabular}{llrcc}
\hline \multicolumn{1}{c}{ Origem } & Destino & $\mathbf{K m}$ & Frete R\$/t & Qtde por composição \\
\hline Campo Grande & Santos & 1.306 & 90,20 & $2.500 \mathrm{t}$ \\
\hline Maracajú & Santos & 1.482 & 102,35 & $1.300 \mathrm{t}$ \\
\hline Campo Grande & Corumbá & 462 & 32,00 & $1.250 \mathrm{t}$ \\
\hline Corumbá & Santos & 1.768 & 94,00 & $1.250 \mathrm{t}$ \\
\hline
\end{tabular}

Fonte: SIFRECA - ESALQ / Ferronorte-ALL (2007)

\section{a.3 - Ferroban}

Tabela 5.8 - Fatores operacionais da Ferroban

\begin{tabular}{ccccc}
\hline Origem & Destino & $\mathbf{K m}$ & Frete R\$/t & Qtde por composição \\
\hline P. Epitácio & Santos & 650 & 45,50 & $2.500 \mathrm{t}$ \\
\hline Pederneiras & Santos & 502 & 39,00 & $5.200 \mathrm{t}$ \\
\hline \multicolumn{5}{c}{ Fonte: SIFRECA - ESALQ / Ferroban-ALL (2007) }
\end{tabular}

\section{a.4 - ALL - Paraná}

Tabela 5.9 - Fatores operacionais da ALL - Paraná

\begin{tabular}{ccccc}
\hline Origem & Destino & $\mathbf{K m}$ & Frete R\$/t & Qtde por composição \\
\hline Maringá & Paranaguá & 520 & 40,00 & $2.100 \mathrm{t}$ \\
\hline
\end{tabular}

Fonte: SIFRECA - ESALQ IALL (2007)

\section{b - Ferropar}

De acordo com os dados obtidos junto à assessoria da Ferropar em Curitiba, do trecho compreendido entre Cascavel e Paranaguá, são adotados os seguintes parâmetros para o estudo:

- Composição Ferroviária: dependendo do tipo de locomotiva, do número de vagões no trem, do trecho a ser percorrido, a composição é considerada variável, uma vez que, entre Cascavel e Paranaguá, existem 4 trechos de tração diferentes, determinados pela rampa crítica existente em cada trecho. Desta forma, para efeito de estudo, foi adotado 2.100 toneladas por composição.

- A distância de Cascavel até Paranaguá é de $737 \mathrm{~km}$, sendo que o valor do frete entre estes dois pontos é variável ao longo do ano. No período de escoamento da safra, de março até julho ou agosto (dependendo do tamanho da safra) o valor do frete sofre um acréscimo. Devido a esta 
variação no valor, é adotado o valor do frete de Fevereiro de 2006 que foi de 47,00/toneladas (Tabela 5.10), que resulta num valor de frete por tonelada quilômetro de $\mathrm{R} \$ 0,063$.

Tabela 5.10 - Fatores operacionais da Ferropar

\begin{tabular}{ccccc}
\hline Origem & Destino & $\mathbf{K m}$ & Frete R\$/t & $\begin{array}{c}\text { Qtde por } \\
\text { composição }\end{array}$ \\
\hline Cascavel & Paranaguá & 737 & 47,00 & $2.100 \mathrm{t}$ \\
\hline \multicolumn{5}{c}{ Fonte: Ferropar }
\end{tabular}

\subsubsection{Custos de Transbordos}

O custo de transbordo é relativo às despesas de transferência da carga a granel, não necessariamente nessa ordem, entre o modal rodoviário, hidroviário e ferroviário.

A deficiência na quantidade e qualidade dos terminais para transbordos brasileiros é uma das causas de ineficiência no setor de transporte de carga (CENTRODELOGISTICA, 2007).

Vários estudos realizados no Brasil revelam um elevado padrão de ineficiência na operação de transportes, especialmente nas atividades de carregamento e descarregamento, em que os tempos de espera geralmente são muito altos em relação aos padrões de outros países. Essa característica resulta em custos de transbordo elevados, o que, em muitas situações, acaba inviabilizando uma operação multimodal.

Diversos trabalhos foram realizados visando aumentar a eficiência e diminuir custos e tempos de transbordo em terminais multimodais. BOTTER (1984) desenvolveu sistemas para a análise da capacidade de terminais portuários, baseados na análise da capacidade de seus subsistemas através de modelos de filas e simulação estocástica. Através da simulação de chegada de barcaças e vagões ferroviários em terminal intermodal rodo-hidro-ferroviário. SANTOS (1998) concluiu que o desempenho do terminal é fortemente influenciado pela variação estocástica nos processos de chegadas destes veículos de transportes. Já MULLER (1999) descreve ainda algumas características importantes no projeto de terminais intermodais, como localização, o acesso e 
a infra-estrutura, além de apresentar os principais tipos de equipamentos de movimentação para cada tipo de carga a ser movimentada.

ANDRADE (2003) desenvolveu um projeto de um terminal intermodal na hidrovia Tietê-Paraná, onde avalia as demandas de movimentação e conseqüentemente os custos por tonelada para as operações de transbordo. Com as mesmas preocupações GUALDA (1995), MASS (2001) E SOUZA (2002) desenvolveram trabalhos visando à localização e planejamento de terminais, além de simulação e avaliação das operações destes.

As taxas de transbordo são definidas por cada terminal específico e, em geral, são estabelecidas de acordo com o tipo de acondicionamento do produto.

As taxas cobradas por terminais de transbordo rodo-ferroviário, rodo-hidroviário e ferro-hidroviário são difíceis de serem levantadas, uma vez que existem muitos terminais de carregamento e que são valores negociáveis. Mas pode-se considerar que são taxas mais baixas do que as cobradas pelos terminais portuários, devido estes últimos possuírem uma maior complexidade na movimentação no porto.

O custo de transbordo de minério, praticado no mercado, é inferior ao cobrado custo cobrado no transbordo da soja. Isso se deve ao fato de que os equipamentos utilizados na transferência, na sua movimentação e na sua armazenagem não são tão complexos. Entretanto, este estudo adota um valor médio das taxas praticadas pelo mercado, tanto para a transferência de soja quanto de minério. Esses valores foram pesquisados junto às empresas AHIPAR, FERROPAR, ALL, CINCONAV e Cia Paulista de Navegação, que realizam este tipo de operação, o que resultou num valor de $\mathrm{R} \$ 3,00$ por tonelada movimentada.

\subsection{ESCOLHA DA FERRAMENTA DE SISTEMA DE INFORMAÇÃO GEOGRÁFICA}

Um SIG é tradicionalmente definido como um sistema de gerenciamento de banco de dados computacional com a função de capturar, armazenar, recuperar, analisar e visualizar dados espaciais. Um SIG-T é uma derivação de SIG, que é aplicado na área de planejamento e operação de transportes. 
As vantagens da utilização desta ferramenta, entre outras, está na alta capacidade de armazenagem, processamento e geração de informações que permitam obter soluções rápidas e precisas para vários problemas, facilitando o processo de tomada de decisões em diversas áreas (SILVA, 1998).

As aplicações do SIG-T já foram demonstradas em diversos trabalhos de diferentes áreas de atuação. SOUTHWORTH \& PETERSON (2000), TIAGO (2002), RORATTO (2003), SILVA (2005) e TEIXEIRA (2007), por exemplo, utilizaram o programa para estudar instalações de terminais intermodais e redes intermodais de transportes. PELIZARO (2000) e SARKIS (2000) o usaram para a roteirização de veículos. Como ferramenta de suporte ao planejamento urbano. LIMA (2003) utiliza um SIG-T com o objetivo de reduzir custos de transporte aos usuários, através do fornecimento de suporte a problemas de decisão espacial na implantação e utilização de equipamentos públicos coletivos (escolas, postos de saúde, etc.)

Devido o TransCAD possuir a capacidade de integração de diversas fontes de dados e apresentação gráfica de resultados, VIVIANI (1998) usa o Transcad para auxiliar a gerência de vias não pavimentadas e LOTTI (2002) investiga a relação de acidentes acontecidos numa estrada às suas características físicas básicas (raio de curvas verticais e horizontais, declividade e comprimento de rampas).

Com essas exemplificações, se pode visualizar o grande campo de aplicação que um sistema de informação geográfica proporciona para os profissionais que atuam na área de análise desses tipos de problemas.

\subsubsection{Redes de transportes}

O termo "rede de transporte" é normalmente usado para descrever uma estrutura que pode ser física (ruas e cruzamentos, linhas de transmissão de energia ou linhas telefônicas, etc.) ou conceitual (listas de informações e pessoas, relações de afiliações e estações de televisão, etc). MORLOK (1978) define rede de transportes como uma concepção matemática que pode ser usada para descrever quantitativamente os sistemas de transportes e outros sistemas com características espaciais. Uma rede inclui dois tipos de elementos: um conjunto de pontos e um conjunto de segmentos de linha 
conectando esses pontos, conforme ilustração na Figura 5.6. Essa observação leva à definição matemática de uma rede como sendo um conjunto de nós (ou vértices ou pontos) e um conjunto de arcos (ou links ou arestas) conectando esses nós. O termo rede de transporte é usado para representar a estrutura física e sua representação matemática é conhecida como "grafo" (NOVAES, 1976).

HILLIER E LIEBERMAN (1988) definem um grafo como sendo um conjunto de pontos, chamados vértices (ou nodos ou nós), conectados por linhas, chamadas de arestas (ou arcos).

Dependendo da aplicação, arestas podem ou não ter direção, pode ser permitido ou não arestas ligarem um vértice a ele próprio e vértices e/ou arestas podem ter um peso (numérico) associado. Se as arestas têm uma direção associada (indicada por uma seta na representação gráfica) tem-se um grafo direcionado, ou dígrafo.

Um grafo com um único vértice e sem arestas é conhecido como o grafo trivial ou "o ponto".

Estruturas que podem ser representadas por grafos estão em toda parte e muitos problemas de interesse prático podem ser formulados como questões sobre certos grafos.

A figura 5.6 representa uma modelo de rede de transporte.

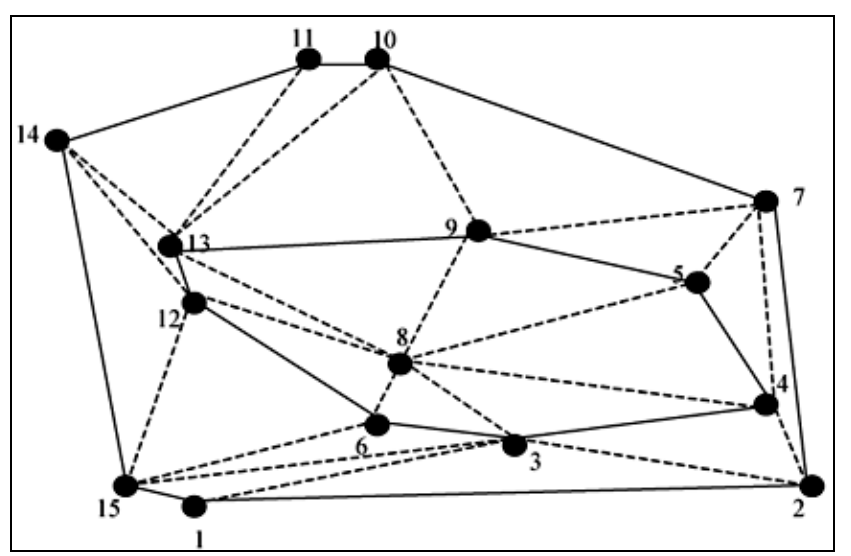

Figura 5.6 - Exemplo de uma rede de transporte Fonte: CARMO (2002) 


\subsubsection{Problema do Transporte e do Caminho Mínimo}

Para entender melhor o Problema do Transporte é necessário descrever o conceito de programação linear, uma vez que a programação linear é bastante aplicada para o planejamento e operação de sistemas de transportes.

NOVAES (1978) descreve a programação linear como uma técnica utilizada para resolver grupo de problemas com limitações de recursos aplicados a atividades ou decisões variadas, objetivando a busca da solução mais próxima do ótimo. De acordo com HILLIER e LIEBERMAM (1988), esses problemas de alocação referem-se a atividades que apresentam competição entre si.

A grande vantagem obtida pela técnica de programação matemática, segundo NEUFVILLE e STAFFORD (1971), é a sua utilização através de software, pois os mesmos realizam cálculos complexos em um tempo reduzido.

Basicamente a Programação Linear é constituída das seguintes variáveis matemática:

Função objetivo: esta representa a variável principal que deseja-se otimizar.

Restrições: são as limitações imposta ao problema, tais como restrições físicas, de recurso monetários e humanos, etc.

Destaca-se entre as inúmeras aplicações da Programação Linear, a utilização para solução do Problema do Transporte (NOVAES, 1978). De acordo com HILLIER e LIEBERMAN (1988), o Problema do Transporte relaciona-se à distribuição de diversos produtos, de diversos centros de oferta (fontes), para vários centros de recebimentos (destinos), objetivando minimizar os custos totais desta distribuição.

Através da utilização de programação linear e grafos, HITCHCOCK (1941), formulou o Problema do Transporte aplicado a uma condição comum em transportes (NOVAES, 1978). Na equação 5.1, 5.2 e 5.3 são apresentadas as formulações matemáticas do modelo para o problema do transporte. 
Se

$$
\begin{gathered}
\sum_{i=1}^{m} x_{i j}=b_{j} j=1,2, \ldots, n \\
x_{i j} \geq 0 \forall i \mathrm{e} j \\
\min \sum_{i=1}^{m} \sum_{j=1}^{n} C_{i j} \times x_{i j} \\
\sum_{j=1}^{n} x_{i j}=a_{i} i=1,2, \ldots, m
\end{gathered}
$$

onde:

Cij: Custo de transporte entre i e j;

xij: Quantidade de produto transportado entre i e j;

m: Número total de origens;

$\mathrm{n}$ : Número total de destinos;

a: Quantidade de um produto;

b: Demanda de um produto.

Podem ser citados, dentre as diversas pesquisas com aplicação do Problema do Transporte, os trabalhos de: SHARMA e SHARMA (2000); MARÍN e PELEGRIN (1996); SUN et al. (1998); TADA e ISHII (1996); SUN (2002). Todos utilizaram esse modelo através da aplicação em técnicas como lógica fuzzy, branch-and-bound, tabu search, etc.

Associado ao Problema do Transporte, o Problema do Caminho Mínimo é outra questão que envolve fluxo em rede. Autores como FORD e FULKERSON, 1962, apresentam algoritmos de programação linear - o método simplex, o algoritmo de Shinbel, de Murchland, de Hu, o out-of-kilten, entre outros - como ferramentas de solução para esse tipo de problema.

Destacam-se como pesquisas do Problema do Caminho Mínimo os trabalhos de: DAVIS JR. (2000); TEIXEIRA E CUNHA (2002); WINSTON (1995); 
BOOKBINDER E FOX (1998) e BELFIORE (2006), os quais utilizam essa técnica para o planejamento e avaliação de roteamento de veículos, operações intermodais, custos de transporte e escolha modal.

Embora sejam o Problema do Transporte e do Caminho Mínimo os precursores dos estudos em pesquisa operacional, e também as duas técnicas mais utilizadas em trabalhos científicos, muitos estudiosos continuam a pesquisá-los e utilizá-los em novas técnicas e ferramentas que surgiram no decorrer do tempo. Isso leva a crer que, mesmo sendo matematicamente simples de serem solucionadas e entendidas, essas técnicas são capazes e eficientes de solucionar diversos problemas.

\subsubsection{Utilização do SIG para Modelo de Rede de Transportes}

O TransCAD resolve o problema de transporte teoricamente fundamentado em um algoritmo adaptado pelo método Simplex para programação linear. Neste quando uma solução é atingida, os números de arcos em fluxo são iguais ao mínimo número de "arcos capacitados", que podem conectar os nós de origem e de destino, e os demais "arcos não capacitados" da rede são desconsiderados. O algoritmo inicia as interações através de uma solução viável com este número mínimo de arcos capacitados e busca através das interações com os arcos não capacitados a melhoria na solução. Se um novo caminho for encontrado, o algoritmo quantifica o fluxo que deve ser direcionado para o novo arco e atualiza a rede (CALIPER, 1996a). Este caso de programação linear do problema de transporte apresenta $m+n-1$ restrições independentes, havendo assim igual número de variáveis básicas (NOVAES, 1978).

O algoritmo de fluxo mínimo que utiliza dois métodos desenvolvido por BERTSEKAS \& TSENG (1998) é outra heurística utilizada pelo TransCAD. O método interativo é baseado na ascensão de duas restrições (custo e capacidade), sendo que o vetor custo associado com a rede de transportes é atualizado simultaneamente com a capacidade dos arcos. O algoritmo é encerrado quando o fluxo atingir a solução mínima viável (CALIPER, 1996a).

Nesta pesquisa não foram conferidas e comparadas as heurísticas descritas no manual do TransCAD (CALIPER, 1996b) com as heurísticas descritas por 
HITCHCOCK (1941) e BERTSEKAS et al. (1988) devido ao fato de não ser o objetivo deste trabalho.

Neste trabalho, se utilizou o SIG - TransCAD versão 3.6 para elaborar o modelo de rede de transportes. Na elaboração dessa rede, o objetivo principal foi apresentar as malhas rodoviária, ferroviária e hidroviária, além dos terminais e regiões produtoras do estado de Mato Grosso do Sul. Também fazem parte desta rede os estados de São Paulo e Paraná uma vez que, para escoar a produção do estado de Mato Grosso do Sul, tem que se utilizar a estrutura de transporte desses estados.

A rede de transporte considerada no trabalho é não capacitada, ou seja, a mesma não possui restrições quanto à capacidade de fluxo nos terminais (nós), modais utilizados (links) e disponibilidade de veículos. Essa adoção se deve principalmente pelo objetivo principal do trabalho ser o de construir e analisar um conjunto de rotas viáveis e de menor custo.

Para melhor visualização das regiões de interesse (os estados de Mato Grosso do Sul, São Paulo e Paraná) é utilizada uma base georreferenciada da malha multímodal brasileira, elaborada pelo IBGE em 1998 e atualizada pela COPPE em 2003.

Foi aberto o banco de dados geográficos do Brasil, elaborado pelo IBGE, escolhendo o arquivo 'ESTADOS.cdf', que abre o mapa geográfico do Brasil com todos os estados. Para melhor visualização das regiões de interesse, os estado de Mato Grosso do Sul, São Paulo e Paraná, foi criada uma nova subbase geográfica das áreas desses estados, utilizando a base já existente.

O mesmo procedimento foi realizado com a base geográfica que contém as áreas dos municípios do Brasil, para a criação do mapa temático das regiões produtoras de soja e minério do estado de Mato Grosso do Sul.

O procedimento para a criação das novas bases está descrito a seguir: Através de Dataview, na Barra de Ferramentas, opção selection by condition, onde foi selecionando em 'Field List', Estados; 'Operator List', o sinal de operação =; em 'Function List; o estado desejado e em 'Selection Method', a opção 'Add to Set'. Ao final, o arquivo foi salvo com o nome do estado, 'MT.dbd'. 
Na seqüência, foi necessário exportar o arquivo gerado, o que foi feito pela ferramenta Tools, opção Export.

Após a criação do novo arquivo geográfico de área para o estado do Mato Grosso do Sul, o mesmo procedimento foi realizado para os outros dois estados. Na seqüência, abriram-se os três novos arquivos geográficos gerados, que foram adicionados sobre o layer aberto inicialmente (ESTADOS.cdf), contendo todos os estados do Brasil (ESTADOS.dbd). Foram ressaltados, na figura, os contornos dos estados de interesse e inseridos os nomes. A Figura 5.7 apresenta os estados de interesse para o trabalho. 


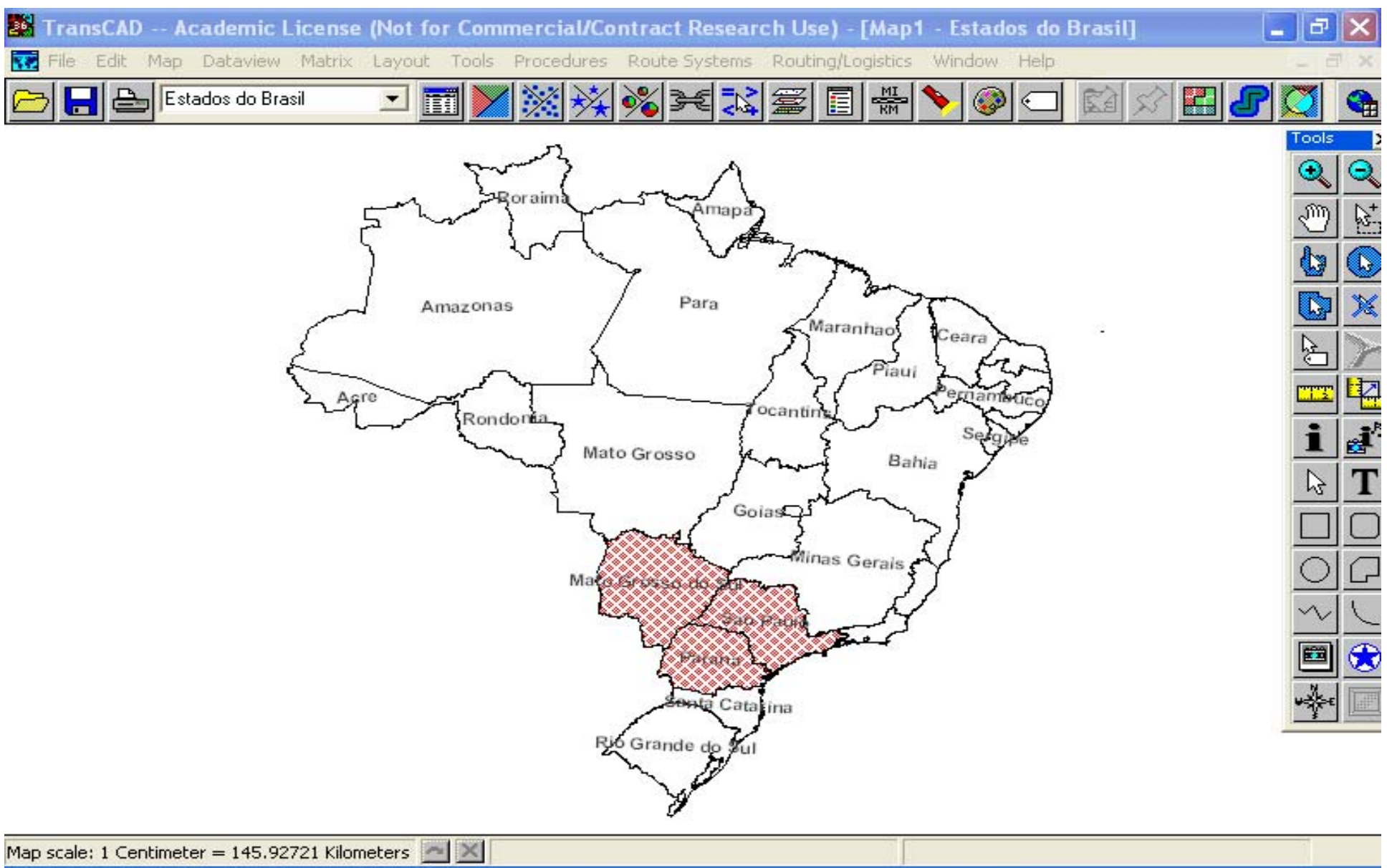

Map scale: 1 Centimeter $=145.92721$ Kilometers 그 $x$

Figura 5.7 - Apresentação dos estados de interesse

Fonte: Elaborada pelo autor 
Para a criação dos mapas temáticos das regiões produtoras de soja e minério, abriu-se o arquivo geográfico gerado para o estado do Mato Grosso do Sul, contendo somente as áreas de seus municípios. As regiões temáticas foram criadas usando a ferramenta Tools, opção Selection. Após isso foi criada uma seleção onde se deu o nome de Região Norte. Na seqüência, através do ícone da caixa de Ferramentas Principal, selecionou-se cada um dos municípios que fazem parte desta região.

O mesmo procedimento foi realizado para as regiões Central, Sul e a do Pólo de Corumbá. A Figura 5.8 ilustra os pólos de produção utilizados na investigação. 


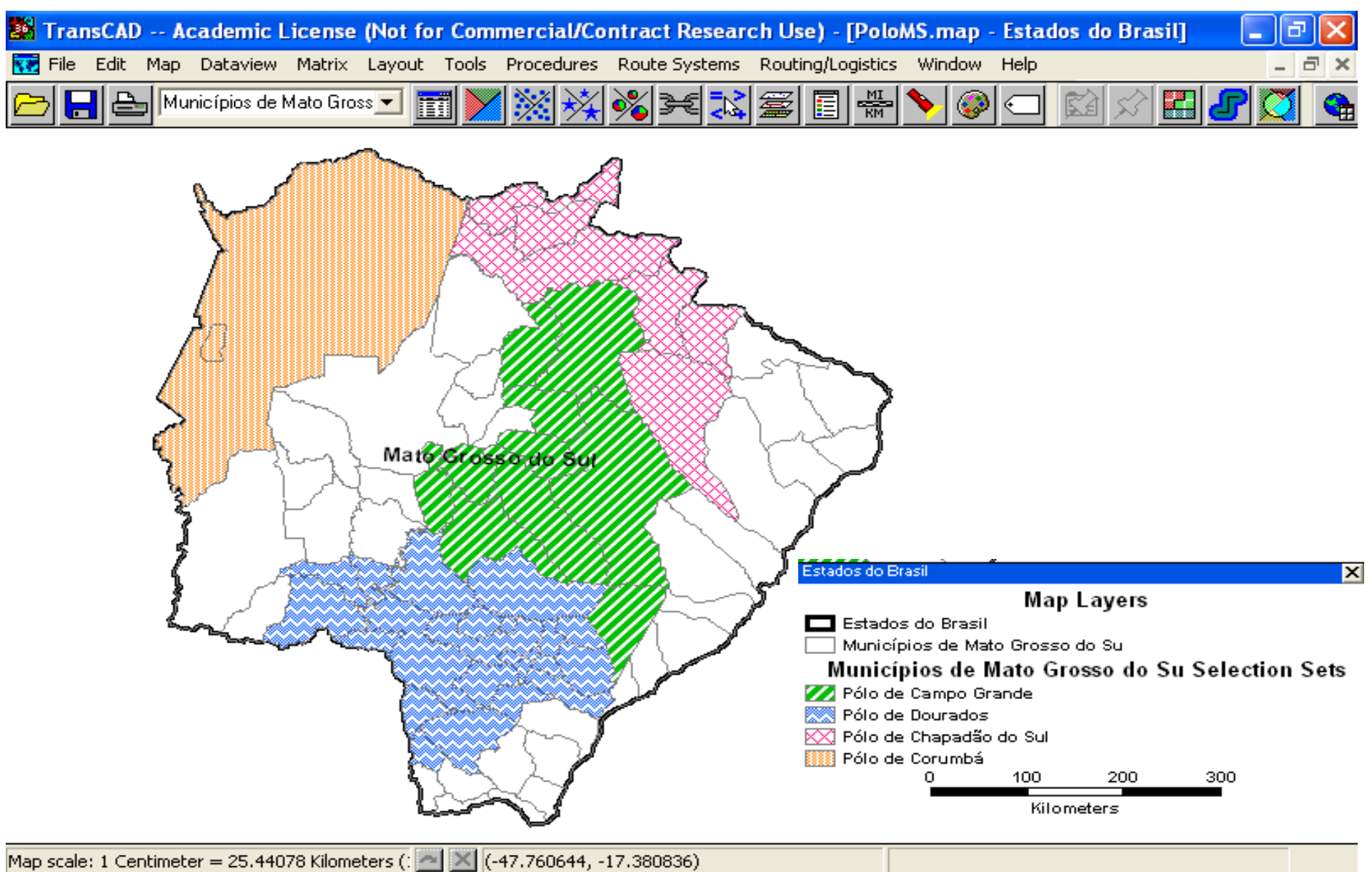

Figura 5.8 - Mapa dos pólos produtores de soja e minério de Mato Grosso do Sul Fonte: Elaborada pelo autor 
Para a inclusão das ferrovias e hidrovias de acordo com os objetivos estabelecidos para o trabalho, foi utilizada a base de ferrovias da COPPE (2003) e a base de hidrovias do IBGE (1998). Para a inclusão das rodovias, também se utilizou o banco de dados do IBGE (1998).

Para a construção desse mapa (Figura 5.9), foi utilizada a ferramenta do TransCAD, que permite criar linhas e atribuir características. Assim foi criado, também, outro arquivo independente das bases mencionadas acima através da ferramenta File/ New, inserindo um arquivo de linhas Line/Geographic file. Nesse mesmo mapa foram identificados os pontos de geração das cargas, assim como os pontos de transbordo e de entrega final dos produtos movimentados. 


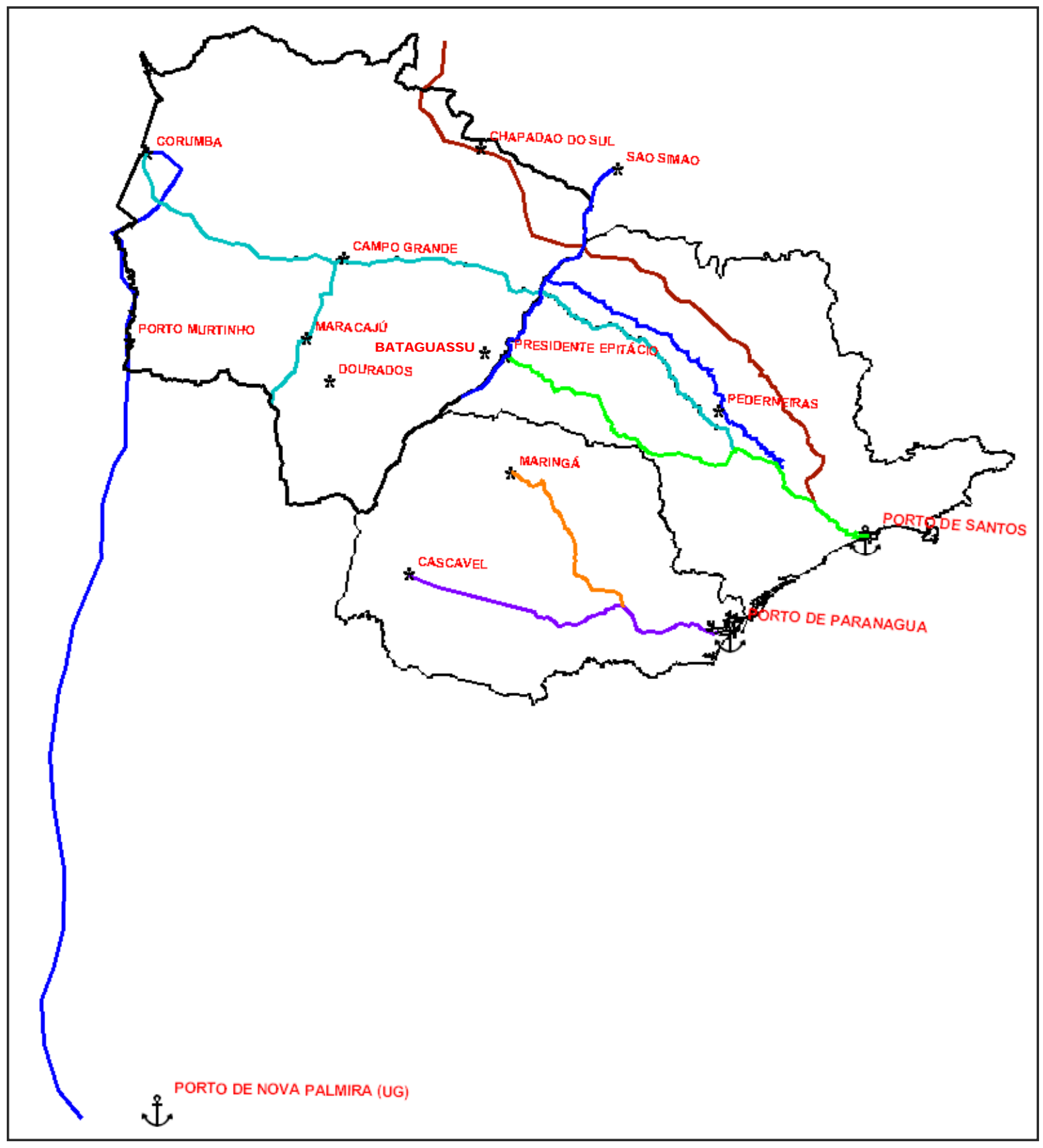

Figura 5.9 - Mapa dos pontos de embarque, transbordo e entrega final das cargas

Fonte: Elaborada pelo autor 


\section{MONTAGEM DOS CENÁRIOS}

O objetivo central desse capítulo é apresentar, por meio de cenários, os custos do transporte da soja e do minério através de diferentes corredores de transporte, utilizando opções monomodais e multimodais expressas em valores por tonelada. Os resultados aqui obtidos serão utilizados no próximo capítulo de análise dos resultados.

O motivo da divisão em cenários se faz em função da possibilidade das alternativas de uso de diferentes modais de transporte (rodoviário, ferroviário e hidroviário), da remuneração do frete de retorno dos veículos utilizados no modal rodoviário, dos produtos a serem transportados (soja e minérios) e também das opções de rotas e suas combinações multimodais.

Com o intuito de avaliar a competitividade que o modal rodoviário exerce nos itinerários o qual possui participação, procedeu-se à análise de sensibilidade para a incidência de fretes de retorno em 0\%, $40 \%$ e $60 \%$ do volume de veículos que retornam com carga a origem, sendo que o valor do frete pago para o retorno equivalente ao custo da volta do veículo no sentido da origem.

São apresentadas também as aplicações sobre os modelos econômicos anteriormente demonstrados neste trabalho, por meio de simulações das integrações multimodais envolvendo os pontos de produção, terminais de transbordo até os pontos finais de recepção.

\subsection{Apresentação dos cenários para o transporte de soja e minério.}

A seguir são descritos os cenários de simulação escolhidos para representar as possíveis alternativas modais para o transporte de soja e minério. 


\section{Cenário 1: Rodoviário 3S2B2}

Nesse primeiro cenário é apresentado o custo do transporte utilizando unicamente o modal rodoviário.

Tabela 6.1 - Descrição do cenário 1

Modo

Tecnologia Rodoviária

\section{Rodoviário}

3S2B2 (lotação 40 toneladas)

Fonte: Elaborado pelo autor

\section{Cenário 2: Rodoviário 3S2B2 - Ferroviário}

Esse cenário estima os custos de transportes utilizando o modal rodoviário e ferroviário onde, nesse último modal, são incluídos os custos de transbordos e as particularidades operacionais referentes às ferrovias utilizadas para 0 escoamento da produção de cada pólo gerador de carga.

Tabela 6.2 - Descrição do cenário 2

\begin{tabular}{ll}
\hline Modo & Rodo-ferroviário \\
\hline Tecnologia Rodoviária & 3S2B2 (lotação 40 toneladas) \\
\hline & Ferronorte (lotação 7.000 toneladas) \\
Tecnologia Ferroviária & Ferroban (lotação 5.200/2.500 toneladas) \\
& Novoeste (lotação 1.250 toneladas) \\
& ALL - Paraná (lotação 2.100 toneladas) \\
& Ferropar (lotação 2.100 toneladas)
\end{tabular}

Fonte: Elaborado pelo autor

\section{Cenário 3: Rodoviário 3S2B2 - Hidroviário - Ferroviário}

$\mathrm{Na}$ análise desse cenário é considerado o transporte pelo modo rodoviário, hidroviário e finalizando com o ferroviário. No modal hidroviário e ferroviário são consideradas também as características particulares de cada ferrovia e hidrovia na composição dos custos, assim como seus custos de transbordo. 
Tabela 6.3 - Descrição do cenário 3

\begin{tabular}{ll}
\hline Modo & Rodo-hidro-ferroviário \\
\hline Tecnologia Rodoviária & 3S2B2 (lotação 40 toneladas) \\
\hline Tecnologia Hidroviária & Tietê-Paraná (lotação 4.000 toneladas) \\
& $\begin{array}{l}\text { Paraguai-Paraná (lotação } 18.000 \\
\text { toneladas) }\end{array}$ \\
\hline Tecnologia Ferroviária & Ferronorte (lotação 7.000 toneladas) \\
& Ferroban (lotação 5.200/2.500 toneladas) \\
& Novoeste (lotação 1.250 toneladas) \\
& ALL - Paraná (lotação 2.100 toneladas) \\
& Ferropar (lotação 2.100 toneladas) \\
\hline
\end{tabular}

Fonte: Elaborado pelo autor

\section{Cenário 4: Ferroviário}

Nesse cenário é utilizado somente o modal ferroviário, levando-se em conta as características de cada ferrovia na composição dos custos e também a distância média da ponta rodoviária da região para o abastecimento do terminal ferroviário com os produtos transportados.

Tabela 6.4 - Descrição do cenário 4

\begin{tabular}{ll}
\hline Modo & Ferroviário \\
\hline Tecnologia Ferroviária & Ferronorte (lotação 7.000 toneladas) \\
& Novoeste (lotação 1.250 toneladas) \\
\hline
\end{tabular}

Fonte: Elaborado pelo autor

\section{Cenário 5: Rodoviário 3S2B2 - Ferroviário - Hidroviário}

No $5^{\circ}$ cenário são apresentados os custos de transporte utilizando os modais rodoviário, ferroviário e finalizando com o hidroviário, onde cada característica particular é considerada nos modais ferroviário e hidroviário. 
Tabela 6.5 - Descrição do cenário 5

\begin{tabular}{ll}
\hline Modo & Rodo-Ferro-hidroviário \\
\hline Tecnologia Rodoviária & 3S2B2 (lotação 40 toneladas) \\
\hline Tecnologia Ferroviária & Ferronorte (lotação 7.000 toneladas) \\
& Novoeste (lotação 1.250 toneladas) \\
\hline Tecnologia Hidroviária & Tietê-Paraná (lotação 4.000 toneladas) \\
& Paraguai - Paraná (lotação 18.000 toneladas) \\
\hline
\end{tabular}

Fonte: Elaborado pelo autor

\section{Cenário 6: Rodoviário 3S2B2 - Hidroviário}

Esse cenário estima os custos de transporte utilizando os modais rodoviário e hidroviário, considerando cada particularidade do modal hidroviário.

Tabela 6.6 - Descrição do cenário 6

\begin{tabular}{ll}
\hline Modo & Rodo-hidroviário \\
\hline Tecnologia Rodoviária & 3S2B2 (lotação 40 toneladas) \\
\hline Tecnologia Hidroviária & Tietê-Paraná (lotação 4.000 toneladas) \\
& Paraguai-Paraná (lotação 18.000 toneladas) \\
\hline
\end{tabular}

Fonte: Elaborado pelo autor

\section{Cenário 7: Ferroviário - Hidroviário}

Nesse cenário, os custos de transporte são estimados utilizando os modais ferroviário e hidroviário, considerando cada característica particular desses modais, além da distância média rodoviária da região para o abastecimento do terminal com os produtos transportados.

Tabela 6.7 - Descrição do cenário 7

\begin{tabular}{ll}
\hline Modo & Ferro-hidroviário \\
\hline Tecnologia Ferroviária & Ferronorte (lotação 7.000 toneladas) \\
& Novoeste (lotação 1.250 toneladas) \\
\hline \multirow{2}{*}{ Tecnologia Hidroviária } & Tietê-Paraná (lotação 4.000 toneladas) \\
& Paraguai-Paraná (lotação 18.000 toneladas)
\end{tabular}




\section{Cenário 8: Hidroviário}

Nesse cenário, apenas o modal hidroviário é utilizado na composição dos custos de transporte, onde é considerada cada particularidade desse modal, além de considerar a distância média rodoviária da região para o abastecimento do terminal hidroviário.

Tabela 6.8 - Descrição do cenário 8

\begin{tabular}{ll}
\hline Modo & Hidroviário \\
\hline Tecnologia Hidroviária & Tietê-Paraná (lotação 4.000 toneladas) \\
& Paraguai - Paraná (lotação 18.000 toneladas) \\
\hline
\end{tabular}

Fonte: Elaborado pelo autor

\subsection{Escolha das rotas de transporte}

$\mathrm{Na}$ simulação para obtenção dos custos totais de transporte, foi utilizado o critério pelo custo total do transporte da carga desde a origem até o destino, sendo utilizado o método de caminho de mínimo custo somente para o modal rodoviário, para o qual também são apresentadas as penalidades tais como: pedágios, balsa, etc.

Para os modais ferroviário e hidroviário, o critério de escolha de pontos de origem e destino baseou-se nos locais onde esses modais possuem terminais intermodais ou proximidade com o pólo gerador de carga.

\subsection{Cálculo da estimativa dos custos de transporte}

Depois da preparação dos dados, conforme apresentado no Capítulo 4, todos os cálculos são executados em planilhas eletrônicas e apresentadas nos Apêndices $B, C, D, E, F, G, I, J, L$ e M detalhando à obtenção dos custos por modal e conseqüente custo total do transporte em todos os cenários propostos. Foi considerado também, nessa análise, que os modais e os corredores de transporte não possuem restrições de capacidade, ou seja, o objetivo principal na obtenção dos custos é avaliar as melhores rotas sejam elas monomodais ou multimodais, em custo total por tonelada transportada. 
Nos cenários de transportes, que utilizam os modais ferroviário ou hidroviário, foi considerado o valor de transbordo, sendo esse valor multiplicado pela quantidade embarcada, compondo assim o custo total.

Desta forma, foram considerados os seguintes critérios para o cálculo dos custos totais por toneladas:

Cenários 1, 4 e 8: nesses cenários há utilização de somente um modal de transporte, portanto a obtenção do custo por tonelada se dá através do produto do custo por quilometro pela quilometragem da rota, somado com suas penalidades e o resultado dividido pela quantidade embarcada no veículo de transporte de cada modal.

Cenários 2, 3, 5, 6 e 7: esses cenários utilizam mais de um modal de transporte entre a origem e o destino final da carga; desta forma, a obtenção do custo total por tonelada é obtido através da soma do custo de cada modal utilizado no trajeto estudado. 


\section{ANÁLISE E DISCUSSÃO DOS RESULTADOS}

São apresentados e discutidos nesse capítulo, os resultados obtidos através das simulações dos oito cenários descritos no Capítulo 6 , assim como a análise dos grupos de cenários que compõem cada pólo gerador de carga. No caso da soja, os pólos de Chapadão do Sul, Campo Grande e Dourados e no caso dos minérios, o pólo de Corumbá. Fazem parte da análise as diferentes rotas que poderão ser utilizadas nos cenários, uma vez que a composição dos cenários se deve à combinação entre os modais de transporte.

Dessa forma, objetiva-se apresentar a melhor opção econômica, dentro do transporte de cada produto analisado e no conjunto global dos cenários. Também, através da análise de sensibilidade, são exploradas algumas situações não previstas inicialmente, as quais podem ser utilizadas para análise de futuros investimentos em infra-estruturas de transporte ou até na alteração das rotas ou trechos para o escoamento da soja e do minério.

\subsection{Análise dos resultados para o transporte de soja.}

\subsubsection{Região Norte - Pólo de Chapadão do Sul}

Neste Pólo de produção, de acordo com os resultados apresentados no Apêndice $D$, tanto considerando $0 \%, 40 \%$ e $60 \%$ de veículos retornando com carga no modal rodoviário, o Cenário 3 composto pelos modais Rodoviário (Chapadão do Sul - Três Lagoas) Hidroviário (Três Lagoas - Pederneiras) e Ferroviário (Pederneiras - Santos) apresenta o menor custo de transporte. A Tabela 7.1 apresenta os resultados e a Figura 7.1 apresenta o mapa desta rota. 
O segundo menor custo para a transferência da soja deste pólo, para a 0\% e $40 \%$ de viagens com retorno de carga, encontra-se no Cenário 3, porém composto pelo itinerário: Rodoviário (Chapadão do Sul - São Simão), Hidroviário (São Simão - Pederneiras) e Ferroviário (Pederneiras - Santos) com uma taxa média 15\% superior ao menor custo. Contudo ainda nesta simulação, o cenário 6 composto pelos modais Rodoviário (Chapadão do Sul Porto Murtinho) e Hidroviário (Porto Murtinho - Nova Palmira) e o cenário 2 composto pelos modais Rodoviário (Chapadão do Sul - Presidente Epitácio) e Ferroviário (Presidente Epitácio - Santos) apresenta uma taxa média de 17\% superior ao menor custo encontrado, o que coloca estes cenários também como segundo menor custo encontrado.

Porém, quando considerado no modal rodoviário 60\% dos veículos retornando com carga, o segundo menor custo, com respectivamente 13\% e 14\% acima do menor custo, encontra-se tanto no Cenário 6, composto pelos modais Rodoviário (Chapadão do Sul - Porto Murtinho) e Hidroviário (Porto Murtinho Nova Palmira), como no Cenário 2, Rodoviário (Chapadão do Sul - Presidente Epitácio) e Ferroviário (Presidente Epitácio - Santos).

Tabela 7.1 - Rotas mais econômicas para o escoamento da região Norte

\begin{tabular}{|c|c|c|c|}
\hline $\begin{array}{c}\text { Veículos retornando } \\
\text { com carga (\%) }\end{array}$ & Cenário & Rota & $\begin{array}{l}\text { Custo Total } \\
\text { (R\$/t) }\end{array}$ \\
\hline & & Rodoviário (Chapadão do Sul - Três Lagoas) & \\
\hline \multirow[t]{3}{*}{$0 \%$} & 3 & Hidroviário (Três Lagoas - Pederneiras) & 93,00 \\
\hline & & Ferroviário (Pederneiras - Santos) & \\
\hline & & Rodoviário (Chapadão do Sul - Três Lagoas) & \\
\hline \multirow[t]{3}{*}{$40 \%$} & 3 & Hidroviário (Três Lagoas - Pederneiras) & 85,49 \\
\hline & & Ferroviário (Pederneiras - Santos) & \\
\hline & & Rodoviário (Chapadão do Sul - Três Lagoas) & \\
\hline \multirow[t]{2}{*}{$60 \%$} & 3 & Hidroviário (Três Lagoas - Pederneiras) & 81,74 \\
\hline & & Ferroviário (Pederneiras - Santos) & \\
\hline
\end{tabular}




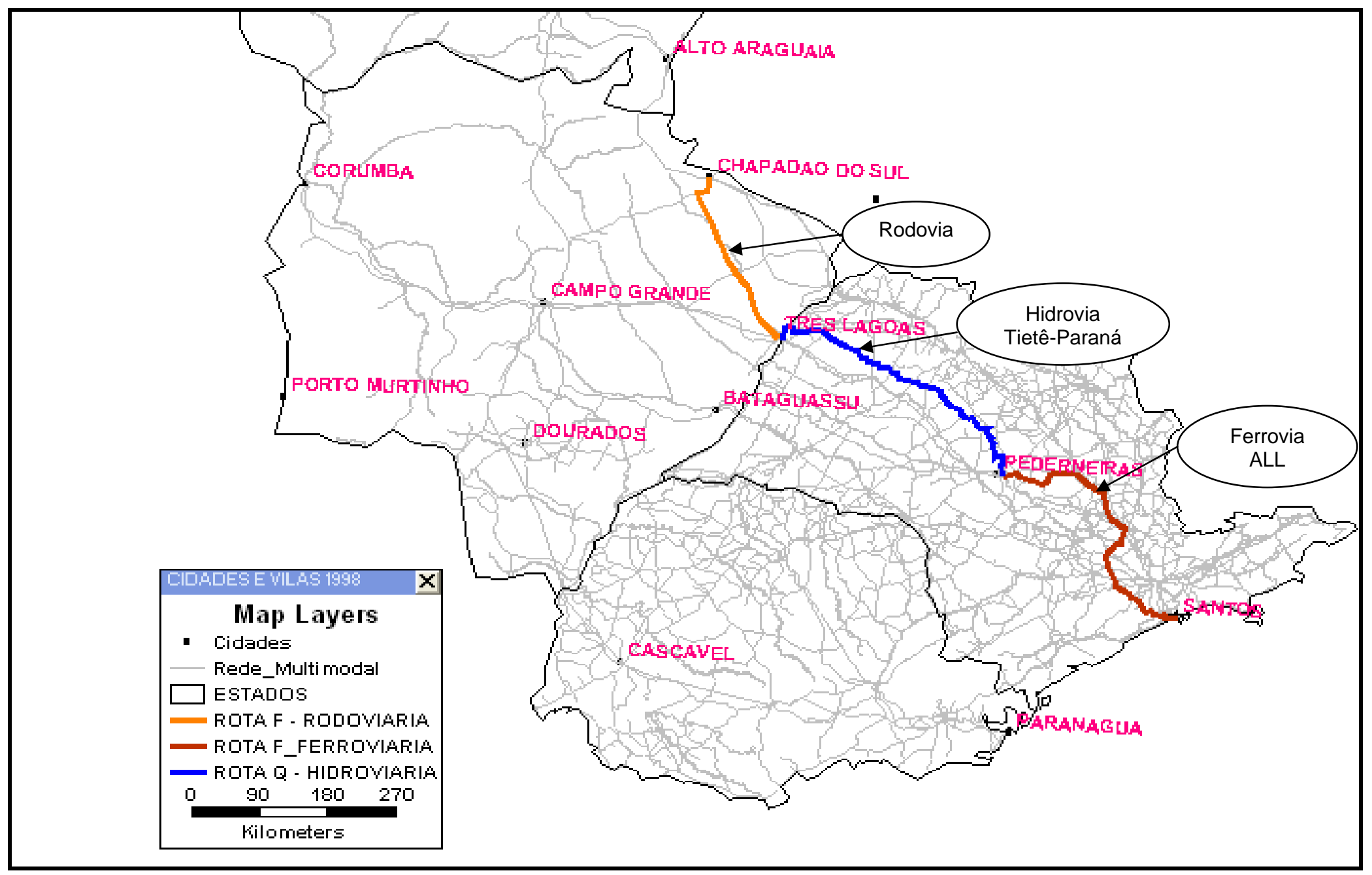

Figura 7.1 - Mapa da rota mais econômica para o Pólo de Chapadão do Sul Fonte: Elaborado pelo autor 


\subsubsection{Região Central - Pólo de Campo Grande}

$\mathrm{Na}$ análise dos resultados apresentados no Apêndice $\mathrm{E}$, constata-se um menor custo no transporte para a opção multimodal composta pelo Cenário 6 .

Este cenário (Tabela 7.2 e Figura 7.2) composto pelos modais Rodoviário (Campo Grande - Porto Murtinho) e Hidroviário (Porto Murtinho - Nova Palmira) apresenta o menor custo em relação aos demais cenários apresentados, para a simulação com 0\%, 40\% e 60\% de veículos retornando com carga no modal rodoviário. O Cenário 7, composto pelos modais, Ferroviário (Campo Grande - Corumbá) e Hidroviário (Corumbá - Nova Palmira) possui o segundo menor custo, com um valor superior de apenas $2 \%$ para $0 \%$ de retorno de carga no modal rodoviário, fazendo deste um forte concorrente para o escoamento da produção deste pólo. Ainda, se mantendo como segunda opção de escoamento mais econômica, o mesmo Cenário 7 apresenta um valor para $40 \%$ e $60 \%$ de retorno de carga no modal rodoviário, respectivamente de $17 \%$ e $27 \%$ superior ao menor custo de escoamento (Figura 7.3).

Apesar do Cenário 7 não estar sendo utilizado plenamente na atualidade, devido ao mau estado de conservação da ferrovia Novoeste, e também a infraestrutura deficiente para embarque nos portos da hidrovia Paraguai-Paraná, observa-se a forte atração que a hidrovia Paraguai-Paraná exerce no escoamento da produção deste pólo, tanto para a combinação rodovia-hidrovia, quanto para a combinação ferrovia-hidrovia.

Tabela 7.2 - Rotas mais econômicas para o escoamento da região Central

\begin{tabular}{cclc}
\hline $\begin{array}{c}\text { Veículos retornando } \\
\text { com carga (\%) }\end{array}$ & Cenário & Rota & $\begin{array}{c}\text { Custo Total } \\
(\boldsymbol{R} \$ \mathbf{t})\end{array}$ \\
\hline $0 \%$ & 6 & $\begin{array}{l}\text { Rodoviário (Campo Grande - Porto Murtinho) } \\
\text { Hidroviário (Porto Murtinho - Nova Palmira) }\end{array}$ & 79,92 \\
\hline $40 \%$ & 6 & $\begin{array}{l}\text { Rodoviário (Campo Grande - Porto Murtinho) } \\
\text { Hidroviário (Porto Murtinho - Nova Palmira) }\end{array}$ & 69,27 \\
\hline $60 \%$ & 6 & Rodoviário (Campo Grande - Porto Murtinho) & 63,94 \\
& & Hidroviário (Porto Murtinho - Nova Palmira) & \\
\hline
\end{tabular}




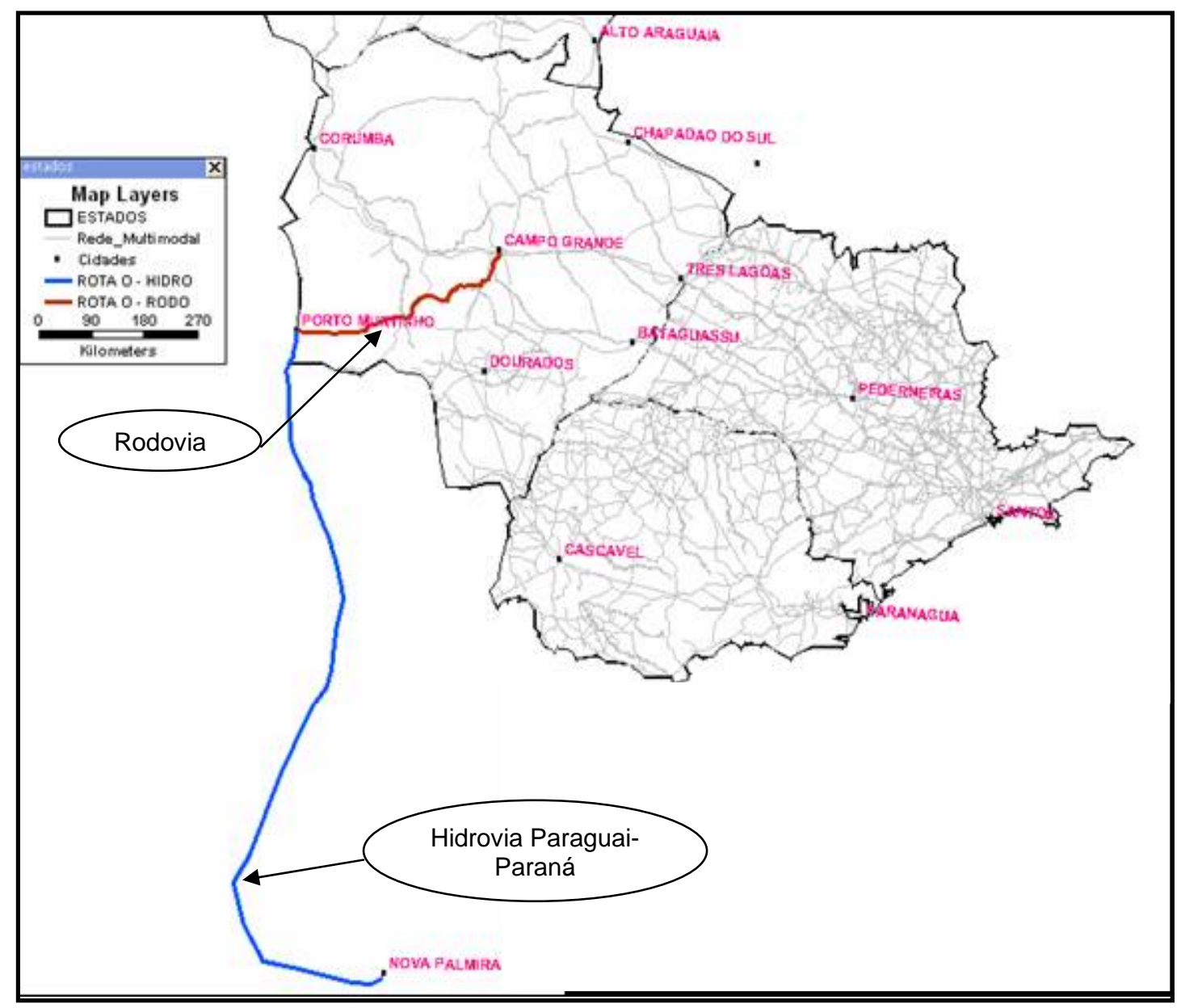

Figura 7.2 - Mapa da rota mais econômica para o Pólo de Campo Grande Fonte: Elaborado pelo autor 


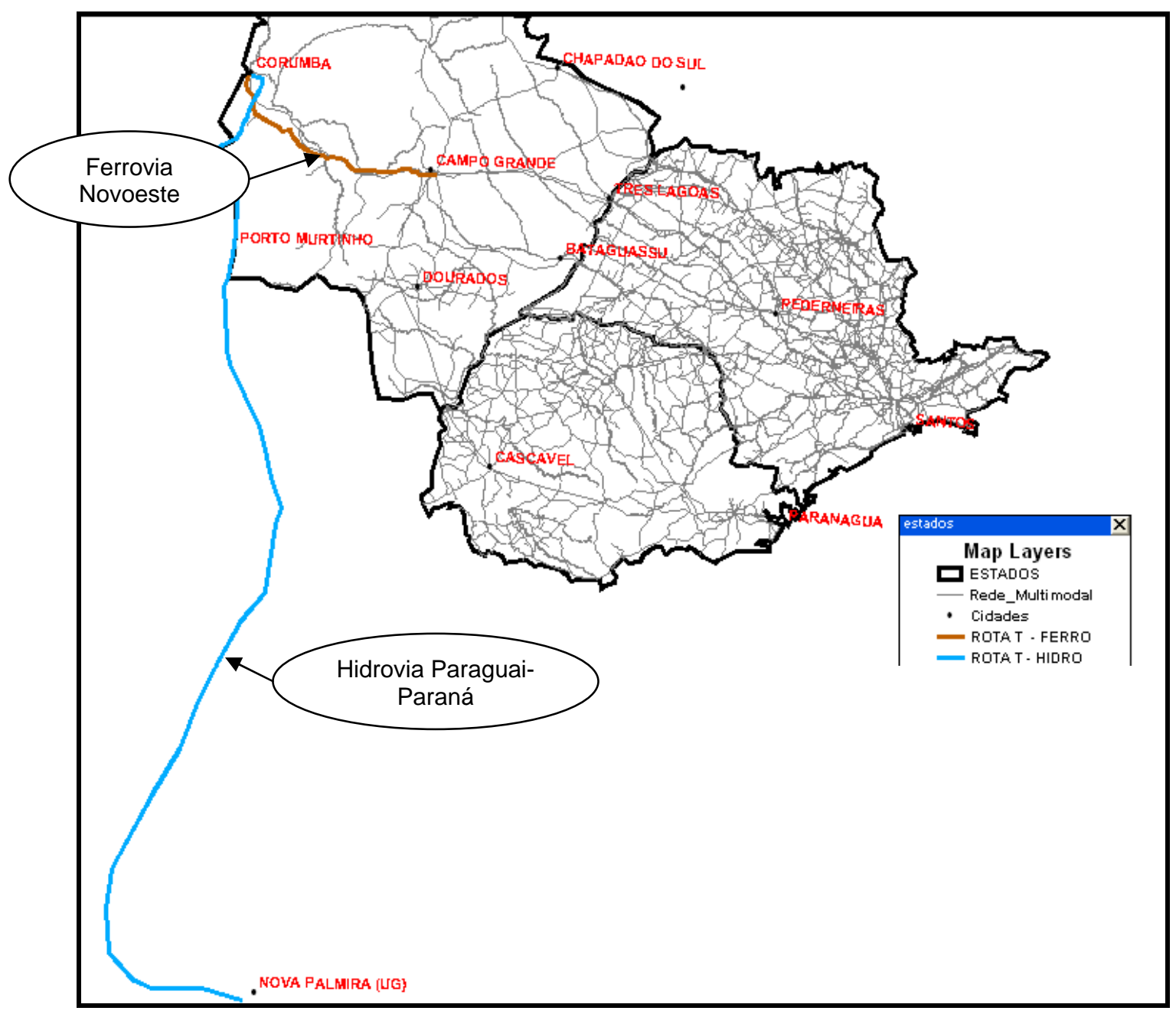

Figura 7.3 - Mapa da segunda rota mais econômica para o Pólo de Campo Grande

Fonte: Elaborado pelo autor

\subsubsection{Região Sul - Pólo de Dourados}

$\mathrm{Na}$ análise dos custos de transporte para esse pólo de produção (Apêndice $\mathrm{F}$ ) constata-se que para a simulação de volume de retorno de $0 \%, 40 \%$ e $60 \%$ de veículos carregados para o transporte rodoviário, o Cenário 6 composto pela combinação multimodal Rodoviário (Dourados - Porto Murtinho) e Hidroviário (Porto Murtinho - Nova Palmira), apresenta o menor custo para o escoamento da produção desta região (Tabela 7.3 e Figura 7.4).

O segundo menor custo para a transferência da soja deste pólo, para a simulação de 0\%, 40\% e 60\% de veículos com carga de retorno, encontra-se no Cenário 2 composto pelo itinerário: Rodoviário (Dourados - Presidente Epitácio) e Ferroviário (Presidente Epitácio - Santos) com taxas de 26\%, 31\% e $34 \%$ respectivamente superior ao menor custo. 
Também no Cenário 2 e, composto pelo itinerário: Rodoviário (Dourados Cascavel) e Ferroviário (Cascavel - Paranaguá) observa-se uma taxa respectivamente de 31\%,34\% e 37\% superior ao menor custo. Ainda na simulação com $60 \%$ de retorno de veículos carregados para o transporte rodoviário, o Cenário 1, Rodoviário (Dourados - Paranaguá), apresenta uma taxa $36 \%$ superior ao menor custo, sendo também, nesta condição, uma segunda opção para o escoamento deste pólo.

Tabela 7.3 - Rotas mais econômicas para o escoamento da região Sul

\begin{tabular}{cccc}
\hline $\begin{array}{c}\text { Veículos retornando } \\
\text { com carga (\%) }\end{array}$ & Cenário & Rotas & $\begin{array}{c}\text { Custo Total } \\
\text { (R\$/t) }\end{array}$ \\
\hline $0 \%$ & 6 & $\begin{array}{l}\text { Rodoviário (Dourados - Porto Murtinho) } \\
\text { Hidroviário (Porto Murtinho - Nova Palmira) }\end{array}$ & 74,00 \\
\hline $40 \%$ & 6 & Rodoviário (Dourados - Porto Murtinho) & 64,53 \\
\hline $60 \%$ & & Ridroviário (Porto Murtinho - Nova Palmira) & 59,79 \\
\hline
\end{tabular}




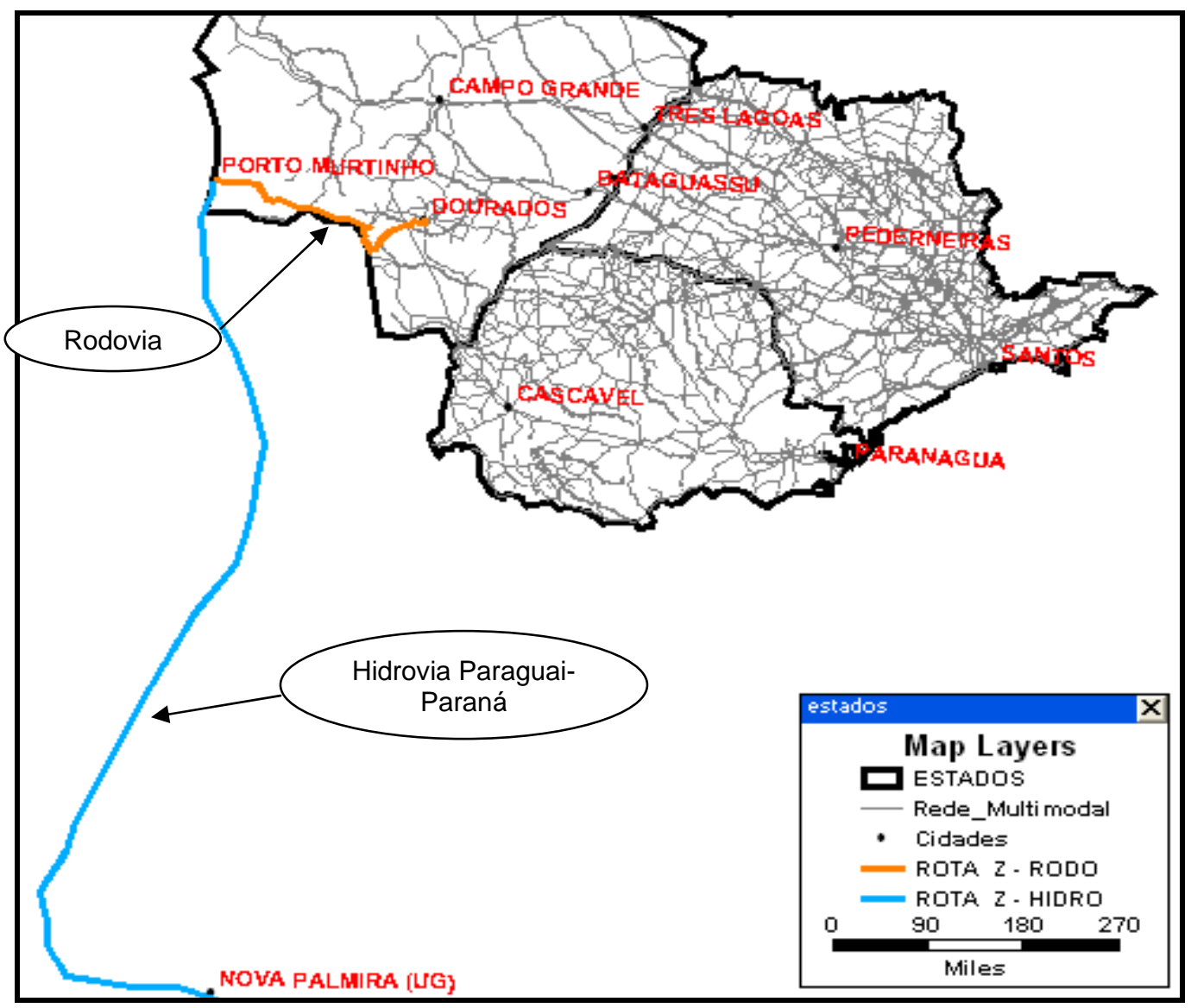

Figura 7.4 - Mapa da rota mais econômica para o Pólo de Dourados Fonte: Elaborado pelo autor

\subsection{Análise dos resultados para o transporte de minérios.}

Em relação aos resultados dos custos de transporte (Apêndice $G$ ) para 0 escoamento de minérios para exportação do pólo de Corumbá, o cenário 8 composto pelo modal Hidroviário (Corumbá - Nova Palmira) apresenta o menor custo para o escoamento, em qualquer das simulações de retorno com carga no modal rodoviário (Tabela 7.4 e Figura 7.5).

Esta especial particularidade com relação ao escoamento de sua produção se deve principalmente por esse pólo estar às margens da hidrovia do ParaguaiParaná, utilizando assim, muito pouco os outros modais para completar a cadeia de transporte. 
Tabela 7.4 - Rotas mais econômicas para o escoamento de minérios

\begin{tabular}{cccc}
\hline $\begin{array}{c}\text { Veículos retornando } \\
\text { com carga (\%) }\end{array}$ & Cenário & Rotas & $\begin{array}{c}\text { Custo Total } \\
(\boldsymbol{R} \$ \mathbf{t})\end{array}$ \\
\hline $0 \%$ & 8 & Hidroviário (Corumbá - Nova Palmira) & 35,89 \\
\hline $40 \%$ & 8 & Hidroviário (Corumbá - Nova Palmira) & 35,89 \\
\hline $60 \%$ & 8 & Hidroviário (Corumbá - Nova Palmira) & 35,89 \\
\hline
\end{tabular}

Fonte: Elaborado pelo autor

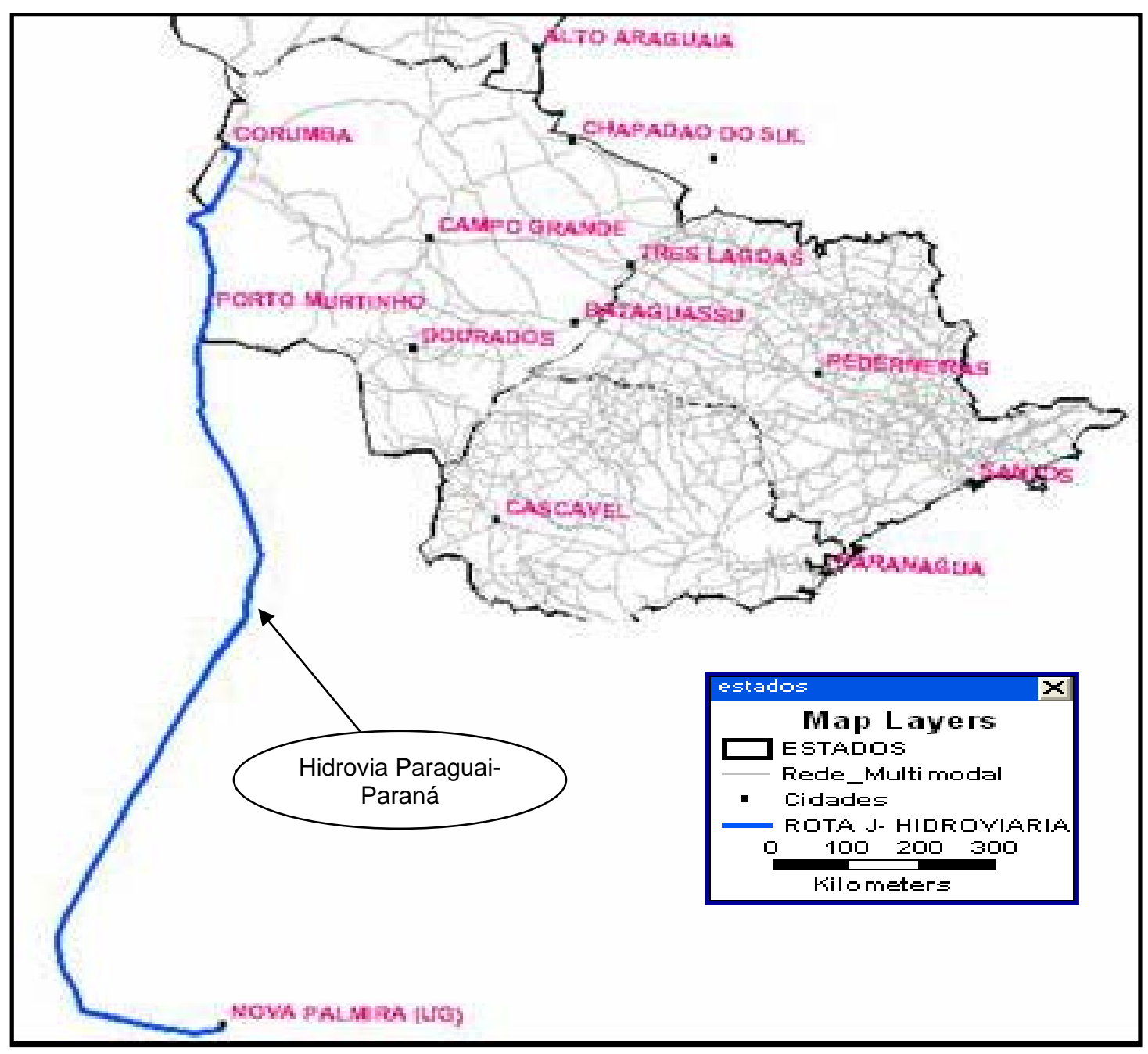

Figura 7.5 - Mapa da rota mais econômica para o Pólo de Corumbá Fonte: Elaborado pelo autor 


\subsection{Análises considerando o Projeto de ampliação da Ferropar.}

Através do Decreto do Governo Federal no 96.913/88, a Ferropar deteve a concessão de construção e operação de uma ferrovia entre Guarapuava no estado do Paraná, e Dourados no estado do Mato Grosso do Sul, a qual servirá o Oeste e extremo Oeste paranaense e o Mato Grosso do Sul. Atualmente, o trecho entre Guarapuava e Cascavel já se encontra em operação, restando a construção entre Cascavel e Dourados.

Para efeito de estudo são também analisados os custos de escoamento da produção dos três pólos geradores de soja e do pólo gerador de minérios com destino ao porto de Paranaguá utilizando esta ferrovia, que ainda está em fase de estudo técnico/econômico para sua implantação. Para efeito de estimativa de custo foi considerada a distância de $171 \mathrm{~km}$ entre Cascavel e Guaíra (ambos no estado do Paraná), trecho já com traçado definido, mais o trecho entre Guairá no estado do Paraná e Dourados no estado de Mato Grosso do Sul. Devido a este último ainda não possuir seu traçado definido, foi considerada para efeito de análise econômica, a distância rodoviária entre Guairá e Dourados.

Na simulação considerada, os pólos de Campo Grande e Dourados quando considerado o cenário de $0 \%$ de viagens com retorno para o modal rodoviário, foram os únicos que apresentam um custo competitivo utilizando essa ferrovia. Os custos observados neste caso são 7\% e $8 \%$ respectivamente superiores a combinação de menor custo (Tabela 7.5 e Figura 7.6).

Todas as opções investigadas para o escoamento da produção dos pólos estudados, utilizando a opção do prolongamento da FERROPAR, são apresentadas na última linha de cada tabela e em fonte itálico nos Apêndices D, E, F, G, I, J, L e M. 
Tabela 7.5 - Rotas mais econômicas com a ampliação da ferrovia Ferropar

\begin{tabular}{|c|c|c|c|c|}
\hline \multirow{2}{*}{ Pólos } & \multirow{2}{*}{$\begin{array}{c}\% \\
\text { Retorno }\end{array}$} & \multirow{2}{*}{ Rotas utilizando a ampliação da Ferropar } & \multicolumn{2}{|c|}{ Custo Total $(R \$ / t)$} \\
\hline & & & Ferropar & Menor Custo \\
\hline \multirow{6}{*}{$\begin{array}{c}\text { Chapadão } \\
\text { do Sul }\end{array}$} & $0 \%$ & Rodoviário (Chapadão do Sul - Campo Grande) & 120,79 & 93,00 \\
\hline & & Ferroviário (Campo Grande - Paranaguá) & & \\
\hline & $40 \%$ & Rodoviário (Chapadão do Sul - Campo Grande) & 112,05 & 85,49 \\
\hline & & Ferroviário (Campo Grande - Paranaguá) & & \\
\hline & $60 \%$ & Rodoviário (Chapadão do Sul - Campo Grande) & 107,68 & 81,74 \\
\hline & & Ferroviário (Campo Grande - Paranaguá) & & \\
\hline \multirow{3}{*}{$\begin{array}{l}\text { Campo } \\
\text { Grande }\end{array}$} & $0 \%$ & Ferroviário (Campo Grande - Paranaguá) & 85,37 & 79,92 \\
\hline & $40 \%$ & Ferroviário (Campo Grande - Paranaguá) & 85,37 & 69,27 \\
\hline & $60 \%$ & Ferroviário (Campo Grande - Paranaguá) & 85,37 & 63,94 \\
\hline \multirow{3}{*}{ Dourados } & $0 \%$ & Ferroviário (Dourados - Paranaguá) & 79,58 & 74,00 \\
\hline & $40 \%$ & Ferroviário (Campo Grande - Paranaguá) & 79,58 & 64,53 \\
\hline & $60 \%$ & Ferroviário (Campo Grande - Paranaguá) & 79,58 & 59,73 \\
\hline \multirow{3}{*}{ Corumbá } & $0 \%$ & Ferroviário (Corumbá - Paranaguá) & 104,57 & 35,89 \\
\hline & $40 \%$ & Ferroviário (Corumbá - Paranaguá) & 104,57 & 35,89 \\
\hline & $60 \%$ & Ferroviário (Corumbá - Paranaguá) & 104,57 & 35,89 \\
\hline
\end{tabular}

Fonte: Elaborado pelo autor

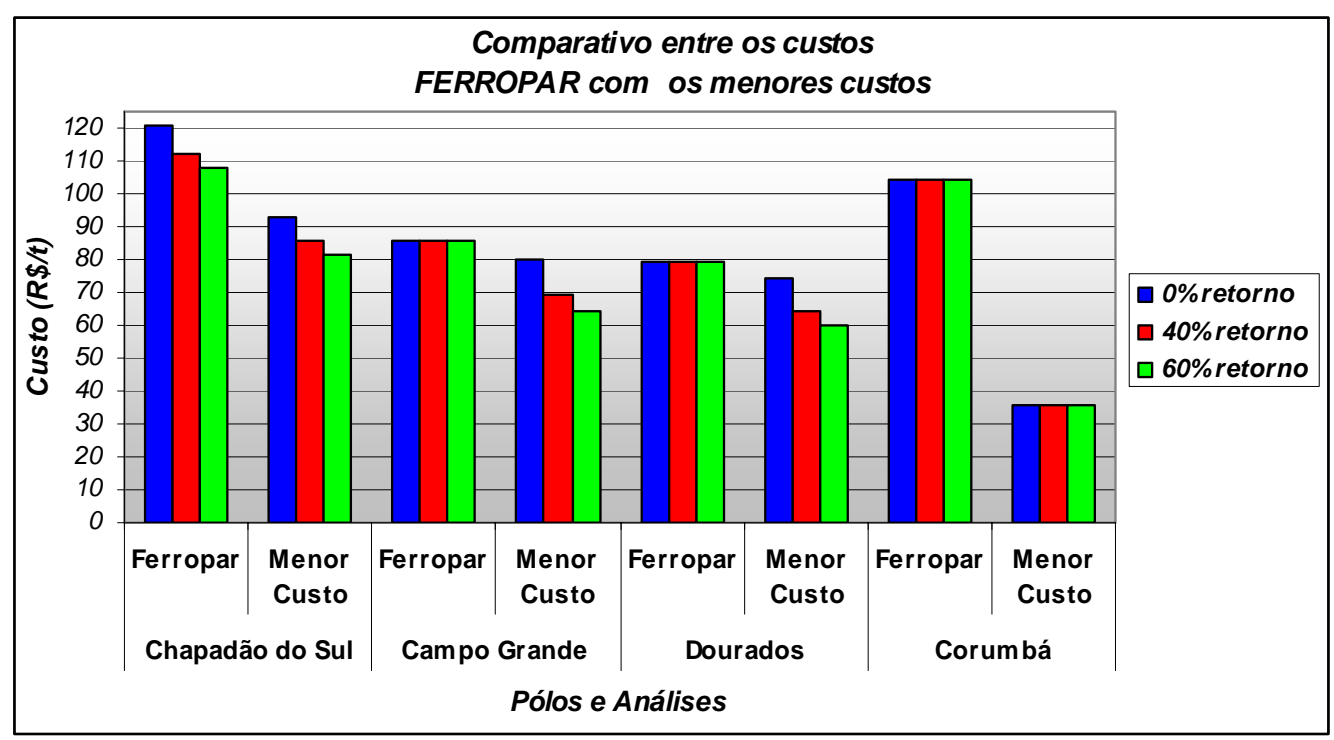

Figura 7.6 - Comparativo com o projeto de prolongamento da Ferropar e os menores custos dos pólos sem o prolongamento

Fonte: Elaborado pelo autor 


\subsection{Análise da atração de cargas dos portos utilizados}

Nesta etapa realiza-se uma análise da atração de cargas que os portos finais realizam sobre os quatro pólos geradores de carga investigados, três de soja e um de minérios.

Esta atração de cargas pode ser observada através da Tabela 7.6, onde são analisados os seguintes portos em questão:

Porto de Santos - somente a produção do pólo de Chapadão do Sul tem como destino esse porto, independente do volume de veículos com retorno carregado.

Porto de Paranaguá - Somente possui atração para o pólo de Campo Grande e Dourados, quando considerado o projeto de ampliação da Ferropar na condição com $0 \%$ de veículos rodoviários com carga de retorno, mesmo assim com valor superior de $7 \%$ e $8 \%$ respectivamente, ao menor custo.

Porto de Nova Palmira - do total de doze simulações de escoamento da produção dos pólos, com menor custo total de transporte, o porto uruguaio de Nova Palmira é tido como destino para nove (75\%) situações de simulação. Os pólos de Campo Grande, Dourados e Corumbá têm este porto como destino nas três condições de análise de veículos com retorno de carga para o transporte rodoviário.

Essa análise se faz necessária, devido principalmente à distância do Porto de Nova Palmira ao do mercado europeu e americano, uma vez que parte da produção de soja e minério têm como destino esses mercados. Tem-se que considerar então, para efeito do cálculo do custo total de transporte, desde o pólo de produção até o país de destino o frete marítimo a partir do Porto de Nova Palmira, além dos seus custos portuários.

Contrapondo a desvantagem acima, quando o destino dos produtos é a Ásia, esse porto apresenta uma melhor posição geográfica em relação ao Porto de Santos e Paranaguá, haja vista o mesmo estar no extremo sul do continente americano. Sua localização permite encurtar a rota para a Ásia, quando comparada às rotas originadas em Santos e em relação a Paranaguá. Contudo essa diferença na distância não reflete obrigatoriamente uma redução no valor 
do frete marítimo, já que a composição desse frete inclui fatores tais como, o custo portuário e o tamanho do navio, entre outros.

Tabela 7.6 - Portos marítimos utilizados pelos pólos de produção

\begin{tabular}{|c|c|c|c|}
\hline Porto & Pólo & $\%$ retorno & Itinerário \\
\hline \multirow{3}{*}{ Santos } & \multirow{3}{*}{$\begin{array}{c}\text { Chapadão } \\
\text { do Sul }\end{array}$} & \multirow{3}{*}{$0 \%, 40 \%$ e $60 \%$} & Rodoviário (Chapadão do Sul - Três Lagoas) \\
\hline & & & Hidroviário (Três Lagoas - Pederneiras) \\
\hline & & & Ferroviário (Pederneiras - Santos) \\
\hline \multirow{5}{*}{$\begin{array}{c}\text { Nova } \\
\text { Palmira }\end{array}$} & Campo & \multirow[b]{2}{*}{$0 \%, 40 \%$ e $60 \%$} & Rodoviário (Campo Grande - Porto Murtinho) \\
\hline & Grande & & Hidroviário (Porto Murtinho - Nova Palmira) \\
\hline & \multirow[b]{2}{*}{ Dourados } & \multirow[b]{2}{*}{$0 \%, 40 \%$ e $60 \%$} & Rodoviário (Dourados - Porto Murtinho) \\
\hline & & & Hidroviário (Porto Murtinho - Nona Palmira) \\
\hline & Corumbá & $0 \%, 40 \%$ e $60 \%$ & Hidroviário (Corumbá - Nova Palmira) \\
\hline
\end{tabular}

Fonte: Elaborado pelo autor

\subsection{Análises de sensibilidade com a utilização do bitrem de nove eixos}

A busca do mercado de transporte por veículos com maior capacidade de carga é uma constante nos dias atuais, principalmente no modal rodoviário. Quando se compara a tecnologia rodoviária utilizada até o final dos anos 80 , semi-reboque 5 eixos com capacidade de carga da ordem de 26 toneladas, e os atuais, bitrens ou rodotrens com capacidade em média de 45 toneladas, constata-se um aumento de aproximadamente $73 \%$ na capacidade de carga desses veículos.

Esse aumento da capacidade de carga é devido a dois fatores principais:

$\checkmark$ Inovação tecnológica desses veículos, tais como potência e capacidade de frenagem;

$\checkmark$ Pressão por redução dos custos de transporte através da diluição dos custos fixos por um maior peso líquido transportado.

Assim, o objetivo principal desta análise de sensibilidade é apresentar a influência da utilização de um veículo rodoviário, bitrem de nove eixos com 
maior capacidade de carga, nos custos de fretes dos cenários analisados. Esse veículo possui capacidade de carga de 52 toneladas, 30\% superior ao bitrem de sete eixos utilizado para a geração dos resultados analisados anteriormente. A Figura 7.7 ilustra um bitrem de nove eixos.

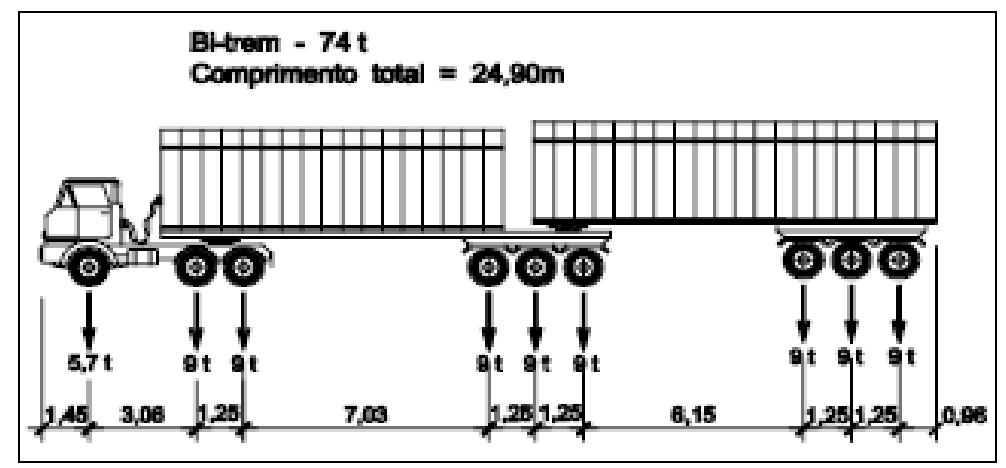

Figura 7.7 - Bitrem de 9 eixos.

Fonte: EESC/DER, 2001

O custo por quilometro encontrado para esse tipo de veículo é de $R \$ 2,66 / \mathrm{km}$ rodado (Apêndice $H$ ), sendo tal valor aplicado somente nos arcos entre os pólos geradores de carga e os terminais de transbordo ou portos de exportação. Para os arcos considerados nas pontas rodoviárias foi mantido o custo por quilômetro utilizado no bitrem de 7 eixos.

Mesmo com uma redução de até $13 \%$ no custo total em alguns itinerários quando utilizado o bitrem de 9 eixos, os itinerários e as combinações modais dos cenários se mantém iguais aos da utilização do bitrem de 7 eixos. Isso se deve principalmente pela pequena redução no custo total, variando entre 2 e $6 \%$, do custo por tonelada proporcionada pela utilização do bitrem de 9 eixos em comparação ao custo do bitrem de 7 eixos. A Tabela 7.7 e Figura 7.8 apresentam a comparação entre os custos de utilização do bitrem de 7 e 9 eixos para os cenários de menor custo de transporte. Já os Apêndices I, J, L e $M$ detalham e apresentam todas as comparações dos cenários estudados.

Tabela 7.7 - Comparativo dos custos com bitrem de 7 e 9 eixos para os cenários de menor custo de transporte.

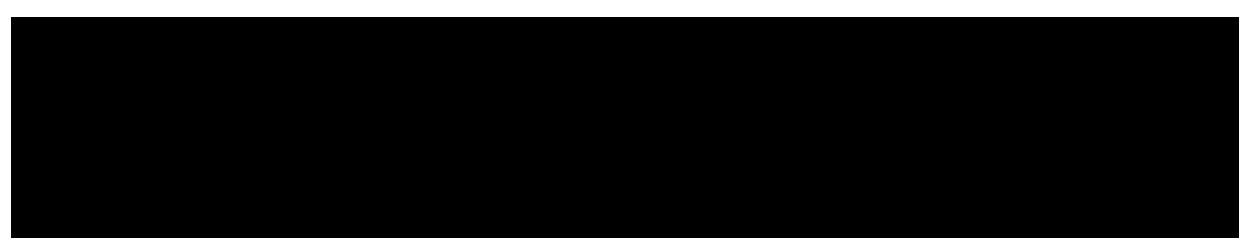




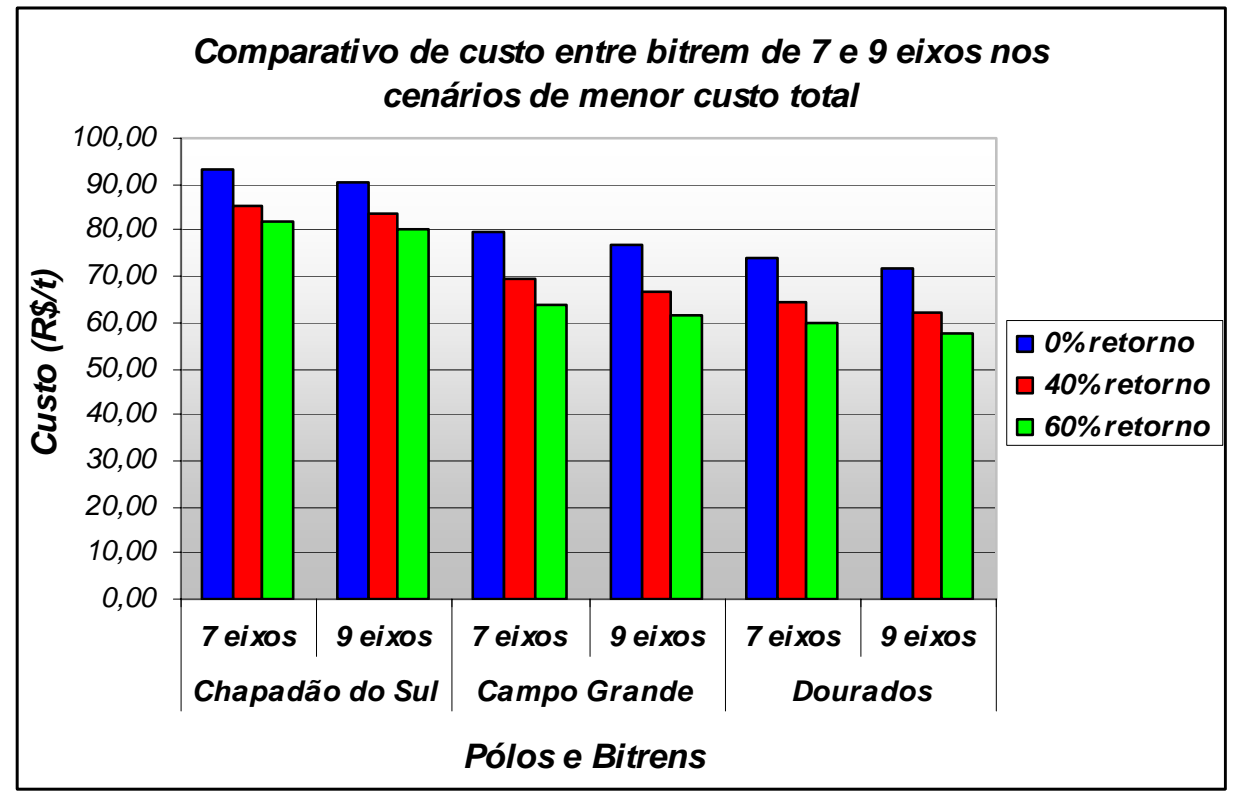

Figura 7.8 - Comparativo dos custos com bitrem de 7 e 9 eixos para os cenários de menor custo de transporte

Fonte: Elaborado pelo autor 


\section{CONCLUSÕES E RECOMENDAÇÕES}

Este trabalho teve como objetivo investigar e analisar as principais alternativas existentes ou futuras para o transporte de soja e minérios de ferro e manganês para exportação, oriundas do estado de Mato Grosso do Sul, além de sugerir estratégias que orientem os órgãos e entidades envolvidas neste mercado.

Dentre as principais conclusões obtidas podem-se destacar:

- A pequena influência dos cenários de remuneração de retorno para o modal rodoviário na seleção da melhor alternativa econômica, uma vez que os cenários com menor custo total são os mesmos para as 3 simulações de remuneração de retorno.

- A utilização do modal hidroviário em todos os cenários que apresentam o menor custo total para a movimentação das cargas dos quatro pólos de produção estudados.

- A forte atração de carga exercida pela hidrovia do Paraguai-Paraná nos quatro pólos, sendo esta utilizada como rota principal ou trecho no escoamento da produção de três dos quatro pólos estudados.

- A análise de sensibilidade da utilização do bitrem de 9 (nove) eixos com maior capacidade de carga, realizada no final do capítulo 7, não implicou alteração alguma dos cenários encontrados na simulação com bitrem de 7 eixos.

- A utilização da ferrovia Ferropar para escoamento da produção dos pólos de Campo Grande e Dourados, é mais econômica somente na condição de $0 \%$ de volume de veículos rodoviários com carga de 
retorno. Nas demais condições o custo do transporte projetado para essa ferrovia não apresenta competitividade econômica.

- A perspectiva de grande desenvolvimento do porto de Porto Murtinho, uma vez que o mesmo é nó de 6 cenários dos pólos de Campo Grande e Dourados. Assim sendo, é necessário capacitá-lo para o atendimento do volume de cargas que serão, provavelmente, a ele direcionados.

- A necessidade de reestruturação do terminal de Porto Esperança para um terminal rodo-ferro-hidroviário. Isto reduziria ainda mais o custo de transporte, já que a maioria das cargas embarcadas na ferrovia Novoeste concentra-se em Corumbá, porto que apresenta um acréscimo de 141 km na rota para Nova Palmira em relação a Porto Esperança.

- A influência do porto de Nova Palmira como pólo de exportação do estado de Mato Grosso do Sul, devendo este sofrer investimentos para sua melhoria operacional, assim como o recebimento de navios de maior porte.

- O porto de Santos, mesmo sendo interligado aos principais corredores de transporte, apresenta vantagem econômica como destino da produção somente para o pólo de Chapadão do Sul. Um aspecto importante a ressaltar neste porto é a diversidade de cargas já processadas pelo porto e o crescimento do comércio exterior brasileiro no período recente. Tais eventos sobrecarregam as operações portuárias, causando estrangulamentos que podem beneficiar ainda mais o escoamento por Nova Palmira. Neste caso, investimentos estratégicos na logística neste corredor podem ser um fator diferencial para atração de operações.

\section{RECOMENDAÇÕES:}

Como complemento deste trabalho sugere-se:

- Investigar a influência que os custos portuários praticados nos portos marítimos de exportação, exercem nos atuais cenários de transporte. 
- Estudar a localização assim como a capacidade de processamento de terminais hidroviários e ferroviários, os quais fomentem a multimodalidade e reduzam os custos totais de transporte.

- Investigar o potencial de utilização da hidrovia Paraguai-Paraná, através do uso de tecnologias de operação e navegação que viabilizem o uso contínuo com maiores volumes de carga ao longo do ano todo.

- Realizar projeto de estudo, considerando a rede de transporte capacitada para os itinerários dos cenários com maior atratividade de cargas.

- Avaliar a saída para o oceano Pacífico, através da utilização da hidrovia do Paraguai-Paraná, com transbordo em portos da Argentina para o modal rodoviário ou ferroviário e nestes seguindo até portos no Oceano Pacífico. 


\section{REFERÊNCIAS BIBLIOGRÁFICAS}

AAKER, David A. (2001). Administração estratégica de mercado. Porto Alegre: Bookman.

AFONSO, H. C. A. G. (2006). Análise dos custos de transporte da soja brasileira. Dissertação (mestrado). Instituto Militar de Engenharia.

AGITRANS (2006) Agência de Gestão e Integração de Transportes de Mato Grosso do Sul. Disponível em <http://www.AGITRANS.ms.gov.br/>. Acesso em: 20 Nov.

AHIPAR (2006) - Administração da Hidrovia do Paraguai. Disponível em <http://www.ahipar.gov.br>. Acesso em: 08 Nov.

AHRANA. (2006) - Administração da Hidrovia do Paraná. Disponível em <http://www.ahrana.gov.br>. Acesso em: 05 Set.

ALL (2006) - América Latina Logística (2006). Disponível em <http://www.alllogistica.com/port/index.asp>. Acesso em: 10 Nov.

ANDRADE, L. E. C. (2003). Um estudo sobre terminais intermodais para granéis sólidos. Dissertação (Mestrado) - Escola Politécnica da Universidade de São Paulo. Departamento de Engenharia Naval e Oceânica.

ANP (2006) - Administración Nacional de Puertos (2006). Disponível em $<$ http://www.anp.com.uy>. Acesso em: 12 Nov.

ANTAQ (2006) - Agência Nacional de Transportes Aquaviários. Disponível em $<$ http://www.antaq.gov.br>. Acesso em 17 Nov.

ANTF (2006) - Associação Nacional dos Transportes Ferroviários. Disponível em < http://www.antf.org.br>. Acesso em: 15 Nov.

BALLOU, R. H. (1993). Gerenciamento da Cadeia de Suprimentos/ Logística Empresarial. Editora Bookman. p.616.

BEILOCK, K. R.; CASAVANT, K. (1984). Perishables: The New Intermodal Battleground . American Journal of Agricultural Economics, Vol. 66, No. 5, pp. 651-656

BELFIORE, P. P. (2006). Redução de custos em logística. Saint Paul Editora. 
BERTSEKAS, D.P.; TSENG, P. (1988). The relax codes for linear minimum cost network problems. Annals of Operations Research, v.13, p. 125-90.

BOTTER, R. C. (1984). Planejamento Portuário: Modelo para Análise Operacional do Sistema Porto Associado a Níveis de Serviço. Dissertação de Mestrado, EPUSP, São Paulo.

BOOKBINDER , J. ; FOX, N.S. (1988). Intermodal Routing of Canada - Mexico Shipments under NAFTA. Transportation Research. Part E, Vol. 34, n. 4, pp. 289-303.

CAIXETA, J. V. (2000). Perspectivas da logística de transportes para os agronegócios brasileiros. Revista Tecnologística, julho.

CALIPER (1996a). TransCAD Transportation GIS Software. User's Guide Version 3.0 for Windows. Capiler Coroporation, Newton, EUA.

CALIPER (1996b). TransCAD Transportation GIS Software. Routing and Logistics with TransCAD 3.0. Capiler Coroporation, Newton, EUA.

CASTRO, N. (2004). Logistic costs and Brazilian regional development. Social Science Research Network.

CASTRO, N.; CARDOSO, L.C.; ESPOSITO, J.R. (1997). Definição e Implementação dos Novos Marcos Regulatórios nas Áreas de Infraestrutura - Setor Ferroviário. Núcleo de Estudos e Modelos Espaciais Sistêmicos - NEMSIS, 1997. Disponível em http://www.nemesis.org.br. Acesso em 10 Abr. 2007.

CARMO, M. R. R. D. (2002). Uma Heurística Interativa para Geração de Caminhos em Grafos com Restrição de Grau: Aplicação ao Projeto de Sistemas Metroviários - Pesquisa Oper. vol.22, no.1 Rio de Janeiro Jan./June. < http://www.scielo.br/>. Acesso em 15 de set. 2007.

CENTRODELOGISTICA (2007) - Centro de Estudos em Logística COPPEAD. Disponível em <http://www.centrodelogistica.com.br/new/pesqtrans/DIAGNOSTICO_e_PLANO_DE_ACAO.pdf >. Acesso em 13 Abr.

CEPE (2001) - Ciclo de Estudos de Política Estratégicas da ADESG - MS. Hidrovia Paraguai Paraná, a hidrovia do mercosul. Corumbá.

CHANG T.-S. (2007). Best routes selection in international intermodal networks. Computers and Operations Research, doi: 10.1016/j.cor.2006.12.025

CINCONAV (2006) - Companhia de Navegação e Comércio. Disponível em $<w w w . c i n c o n a v . c o m . b r>$. Acesso em 10 Nov. 
CNI (2006) - Confederação Nacional das Indústrias. Disponível em <http://www.cni.org.br/f-ps-ie.htm>, acesso em 10 Ago.

COOPER, R., KAPLAN, ROBERT S. (1998). The design of Cost Management Systems, Prentice Hall.

COSTA, J. I. A. (1979). Comparação econômica entre transportes ferroviário e rodoviário - aplicação para escoamento regional de carga agrícola. Dissertação (Mestrado) - Instituto Militar de Engenharia, Rio de Janeiro.

DAVIS JR., C. A. (2000). Aumentado a eficiência da solução de problemas de caminho mínimo em SIG. Empresa de informática e informação de Belo Horizonte S/A. - PRODABEL.

DNIT (2006) - Departamento Nacional de Infra-estrutura em Transportes.

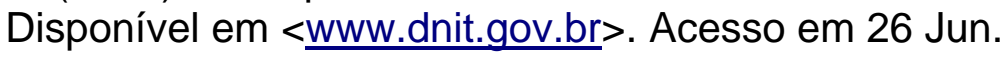

DNPM (2006) - Departamento Nacional da Produção Mineral. Disponível em <http://www.dnpm.gov.br/conteudo.asp>. Acesso em $20 \mathrm{Jul}$.

DUGONJÍC, V. (1989). Transportation: benign influence or an antidote to regional inequality? Papers of the Regional Science Association. v. 66, p. 61-76.

FAHEY, L.; RANDELL, R. (1998). Learning from the future: competitive foresight scenarios. Editora Ratcliffe, J.

FAJARDO, A. (2001). Escoamento da soja produzida nos estados do Pará e Mato Grosso - Análise de Alternativas. Dissertação (Mestrado). Universidade Federal do Rio de Janeiro - COPPE, Rio de Janeiro.

FERRONORTE (2006) - Ferrovias Norte Brasil. Disponível em <http://www.brasilferrovias.com.br>. Acesso em 10 Out.

FERROPAR (2006) - Ferrovia Paraná S/A. Disponível em $<$ http://www.ferropar.com.br>. Acesso em 25 Out.

FLUVIOMAR (2006) - Grupo Fluviomar - Disponível em <http://www.fluviomar.com/es/industria/logros.htm>. Acesso em 10 Set.

FORD, L.R.; FULKERSON, D.R. (1962). Flows in Networks. Princeton University Press, Princeton, N.J.

FUNDAÇÃOFIA (2006) - Fundação Instituto de Administração <http://www.fundacaofia.com.br/pensa/>. Acesso em 01 Ago. 
GUALDA, N. F. (1995). Terminais de transportes: contribuição ao planejamento e ao dimensionamento operacional. Tese (Tese Livre Docência) Departamento de Engenharia de Transportes, Escola Politécnica, Universidade de São Paulo. São Paulo.

GRANEL - Granel Química Ltda. (2006). Disponível em $<$ http://www.granel.com.br>. Acesso em 03 Nov.

HILLIER, F.S.; LIEBERMAN, J. (1988). Introdução à Pesquisa Operacional. 3 ed. (1. ed. Em português). São Paulo-SP. Universidade de São Paulo.

HITCHCOCK, F. L. (1941). Distribution of a product from several sources to numerous localities. Journal of Math. Physics, v.20.

IBGE (2006). Instituto Brasileiro de Geografia e Estatística. Disponível em <http:/www.ibge.com.br>. Acesso em 15 Nov.

JORNAL GAZETA MERCANTIL (2007). Parâmetro de frete é o caminhão, publicado em 22 de abr.

KASTURIA, S. (1995). An econometric study of intermodal competition: The case of German transportation. Ph.D. (Thesis). Northwestern University.

KATO, J. M. Cenários estratégicos para o transporte rodoviário de cargas no Brasil. Florianópolis 2005. Tese (Doutorado em Engenharia de Produção) Programa de Pós-graduação em Engenharia de Produção, UFSC, 2005.

KAWAMOTO, E. (1999). Análise de sistemas e transporte. $2^{a}$ edição, São Carlos.

KOMAROVA, A. D. H. (2000). Transporte multimodal de cargas: análise de alternativas. Dissertação (Mestrado). Instituto Militar de Engenharia, Rio de Janeiro.

LAMOSO, L. P. (2001). A exploração de Minério de ferro no Brasil e no Mato Grosso do Sul. São Paulo - Tese (Doutorado em Geografia) - Faculdade de Filosofia, Ciências e Letras - Universidade de São Paulo.

LIMA, R. S. (2003). Bases para uma metodologia de apoio à decisão para seviços de educação e saúde sob a ótica dos transportes. 200p. Tese (Doutorado) - Escola de Engenharia de São Carlos, Universidade de São Paulo, São Carlos.

LITTLE, A. D. (2002). Planejamento de Cenários. In: Estratégia e Planejamento: Autores e Conceitos Imprescindíveis - coletânea HSM Management. São Paulo: Publifolha. 
LOTTI, C.P. (2002). Método de Sistematização e Levantamento de Dados para o Estudo da Relação de Acidentes com o Alinhamento em Planta e Perfil de uma Rodovia. Tese (Doutorado) - Escola de Engenharia de São Carlos, Universidade de São Paulo, São Carlos.

LOUREIRO, C. F. G. (1994). Modeling investiment options for multimodal transportation network. Thesis (Doctor) - Universidad Tennesse Knoxville.

MARTELLI, A. (2001). Scenario Building and scenario planning: state of the art and prospects of evolution. In: Future Research Quarterly. Disponível em: http://www.antoniomartelli.com/hmt/articoli/scen_building.asp. Acesso em: 15 de abril de 2006.

MARINHA DO BRASIL (2006) - CAPITANIA FLUVIAL DO TIETÊ-PARANÁ. Disponível em <https://www.mar.mil.br/cttp/down/xnpcf_rev1.pdf>. Acesso em: 26 Nov.

MARTINEZ JÚNIOR, L. C. (1997). "Protótipo de Sistema de Custeio e Formação de Fretes Ferroviários", Trabalho de Formatura, EPUSP.

MARÍN, A.; PELEGRÍN, B. (1996). A Branch and Bound Algorithm for the Transportation Problem with Location of Transshipment Points. Computers Operations Research, vol. 24, n. 7, pp. 659-78.

MASS, C. A. (2001). Projeto de Terminais Intermodais de Carga Utilizando os Conceitos CADD e Simulação. Campinas, Faculdade de Engenharia Civil, Universidade Estadual de Campinas. 75 p. Dissertação de Mestrado.

MASSELLA, M. M. B. (1979). Estudo de custos de transportes rodo-hidroviário: caso do corredor ljuí/Rio Grande. Dissertação (Mestrado). Instituto Militar de Engenharia, Rio de Janeiro.

MASSER, I., SVIDEN, O., WEGENER, M. (1992). From growth to equity and sustainability - paradigm shift in transport planning. Futures (July-August).

MASSER, I., SVIDEN, O., WEGENER, M. (1993). Transport planning for equity and sustainability. Transportation Planning and Technology 17, 319-330.

MESQUITA, A. H. M. (1980). Estudo intermodal do transporte de carga em um corredor - aplicação no macro-eixo Rio/São Paulo. Dissertação (Mestrado). Instituto Militar de Engenharia, Rio de Janeiro.

MICHAELS, G. H.; LEVINS, R. A.; FRUIN, J. E. (1982). Rail/Truck Competition for Grain Traffic in Minnesota: Implications for Rate Making. American Journal of Agricultural Economics, Vol. 64, No. 2 , pp. 276-279 
MIETZNER, D; REGER, G. (2004). Scenario Approaches - History, differences, advantages and disadvantages. In: EU-US SEMINAR: NEW TECHNOLOGY FORESIGHT, FORECASTING \& ASSESSMENT METHODS, Seville, p- 4766.

MINISTÉRIO DOS TRANSPORTES (2006). Disponível em $<$ http://www.transportes.gov.br/>. Acesso em: 02 Set.

MRE (2006) - MINISTÉRIO DAS RELAÇÕES EXTERIORES. Disponível em $<$ http://www2.mre.gov.br/dai/m 2716 1998.htm>. Acesso em: 16 Jun.

MORAES, G. M. (2003). Análise Prospectiva da Capacidade de Processamento de Cargas pela Ferrovia no Porto de Santos. São Carlos. Dissertação (Mestrado). Escola de Engenharia de São Carlos, Universidade de São Paulo

MORLOK, E. K. (1978). Introduction to Transportation Engineering and Planning. McGraw Hill Kogakusha Ltda, Tokio.

MULLER, G. (1999). Intermodal Freight Transportation. Eno Transportation Foundation, Inc., $4^{\mathrm{a}}$ Edição, Washington, DC.

NEUFVILLE, R.; STAFFORD, J.H. (1971). Systems Analysis for Engineers and Managers. Mc Graw-Hill, New York.

NTC \& Logística (2006) - Associação de Transportes de Cargas e Logística. Manual de Cálculo de Custos e Formação de Preços do Transporte Rodoviário de Cargas.

NIJKAMP, P., BLAAS, E. (1994). Input Assessment and Evaluation in Transportation Planning. Kluwer Academic Publishers, Dordrecht.

NIJKAMP, P., RIENSTRA, S., VLEUGEL, J. (1998). Transportation Planning and the Future. John Wiley \& Sons Ltd., Chichester England.

NOVAES, A. G. (1976). Economia e Tecnologia do Transporte Marítimo. Almeida Neves Editores. Rio de Janeiro.

PELIZARO, C. (2000). Avaliação de desempenho do algoritmo de um programa comercial para roteirização de veículos. Dissertação (Mestrado). Escola de Engenharia de São Carlos, Universidade de São Paulo, São Carlos.

PIRES, F. (2000). Os Avanços do Transporte Ferroviário de Carga no Brasil após as Privatizações: uma Análise Segundo a Perspectiva de Usuários, Prestadores de Serviço e Governo. Centro de Estudos em Logística (CEL) - Coppead - UFRJ. 
PIRES JÚNIOR, F. C. M. (1989). Custo de Transporte Aquaviário. Apostila. Rio de Janeiro: COPPE/UFRJ.

PORTOSDOPARANA (2006) - Administração dos Portos de Parnaguá e Antonina. Disponível em http://www.portosdoparana.com.brl. Acesso em 02 fev.

PORTER, M. E. (1988). Estratégia Competitiva. 17 ed. Rio de Janeiro: Campus.

PRESCOTT, J. E. \& MILLER, S. H. (2002). Inteligência Competitiva na Prática: Técnicas e práticas bem sucedidas para conquistar mercados. Rio de Janeiro: Campus.

RAVARA, A. (2005). Transporte Ferroviário de Cargas: Método de Custeio e Determinação de Fretes. Dissertação (Mestrado). Escola Politécnica da Universidade de São Paulo.

RINGLAND, Gill (2002). Scenarios in Business. West Sussex, UK: John Wiley \& Sons.

RORATO, R. J. (2003). Alternativas de transporte rodo-marítimo na distribuição de cargas frigoríficas no Brasil. Dissertação (Mestrado em Transportes). Escola de Engenharia de São Carlos, Universidade de São Paulo, São Carlos.

ROUBELAT, F. (2000). Scenario planning as a networking process. In: TECHNOLOGICAL FOREST AND SOCIAL CHANGE, v. 65.

SAMUELSON, R. (1977). Modelling the freight rate structure. MIT (CTS Report, $77-7)$.

SANTOS, S. R. C. (1998). Análise das Incertezas dos Processos de Chegadas na Operação de um Terminal Intermodal. Dissertação (Mestrado). Escola de Engenharia de São Carlos.

SANT`ANNA, J. A. (1998). Rede Básica de Transportes da Amazônia. IPEA, Brasília.

SARKIS, L. F. P. G. (2000). Resíduos de serviços de saúde em cidades de médio porte: caracterização de sistemas de coleta e aplicação de um sistema de informação geográfica na roteirização de veículos de coleta e transporte. Dissertação (Mestrado em Transportes). Escola de Engenharia de São Carlos, Universidade de São Paulo, São Carlos.

SCHWARTZ, P. (2000). A Arte da Visão de Longo Prazo: Planejando o futuro em um mundo de incertezas. São Paulo: Best Seller. 
SECRETARIA DE ESTADO DOS TRANSPORTES DE SÃO PAULO (2006). Disponível em <http://www.transportes.sp.gov.br/v20/hidrovia.asp>. Acesso em 25 Ago.

SEINFRA (2006) - Secretaria de Infra-Estrutura. Disponível em $<$ http://www.seinfra.ce.gov.br/>. Acesso em 05 Nov.

SELTRA (2006). Disponível em <http://www.seltra.ms.gov.br>. Acesso em 05 Nov.

SHARMA, R.R.K.; SHARMA, K.D. (2000). A New Dual Based Procedure for the Transportation Problem. European Journal of Operational Reserach, Theory and Methodology, vol. 122, pp. 611-24.

SIFRECA (2006) - Sistema de Informações de Fretes. Disponível em $<$ http://www.sifreca.esalq.usp.br>. Acesso em 03 Maio.

SILVA, A. N. R. (1998). Sistemas de Informações Geográficas para Planejamento de Transportes. Livre docência. Escola de Engenharia de São Carlos, Universidade de São Paulo, São Carlos.

SILVA, V. B. (2005). Distribuição modal rodo-ferroviária em uma rede de exportação de açúcar a granel para o porto de Santos. Dissertação (Mestrado em Transportes). Escola de Engenharia de São Carlos, Universidade de São Paulo, São Carlos.

SMITH, A. (1998). A Riqueza das Nações. Editora Momento Atual. p. 512.

STEAD, D., BANISTER, D. (1999). Transport Policy Scenario Building: Findings from the POSSUM Project, NECTAR conference, Delft, October.

SOUTHWORTH, F.; PETERSON, B. E. (2003). Intermodal and international freight network modeling. Transportation Research. Part C.

SOUZA, F. A. F. (2002). Elaboração de um Modelo de Localização de Cargas Unitizadas Agroindustriais em Pátios Portuários: Aplicação ao Caso do Terminal Portuário do Pecém. Fortaleza. Dissertação (Mestrado em Engenharia de Transportes) - Programa de Mestrado em Engenharia de Transportes, Centro de Tecnologia, Universidade Federal do Ceará, Fortaleza, 2002.

SOUSA, F. L. (2002). A localização da indústria de transformação brasileira nas últimas três décadas. II ENCONTRO DA ASSOCIAÇÃO BRASILEIRA DE ESTUDOS REGIONAIS, São Paulo. São Paulo.

SOUZA, F. M.; MANFRINATO, J.W.S.; NETO, L.F.F. (2005). Análise Econômica da Implantação de um Sistema de Transporte Combinado 
Rodo-Ferroviário no Corredor Bauru - São Paulo. Disponível em $<$ http://simpep.feb.unesp.br/anais10/gestãodaproducao/arq35.PDF>.

Acesso em 02 de Abr. 2007.

SUN, M . (2002). The Transportation Problem with Exclusionary Side Constraints and Two Branch-and-Bound Algorithms. European Journal of Operation Research, Discret Optmization, vol. 140, pp. 629-47.

SUN, M.; ARONSON, J.E.; McKeoWN, P.G.; DRINKA, D. (1998). A Tabu Search Heuristic Procedure for the Fixed Charge. European Journal of Operation Research, vol. 106, pp. 451-56.

TADA, M.; ISHII, H. An Integer Fuzzy Transportation Problem. Computers \& Mathematics with Applications, vol. 31, n. 9, pp. 71-87, 1996.

TEIXEIRA, R.G. e CUNHA, C.B. (2002). Heurísticas para o Problema de Dimensionamento e Roteirização de uma Frota Heterogênea Utilizando o Algoritmo Out-of-Kilter. TRANSPORTES, v.10, n.2, p.9-30.

TEIXEIRA, K. M. (2007). Investigação de opções de transporte de carga geral em contêineres nas conexões com a região amazônica. Tese (Doutorado). Escola de Engenharia de São Carlos, Universidade de São Paulo, São Carlos.

TEIXEIRA FILHO, J. L. L. (2001). Modelos analíticos de fretes cobrados para o transporte de cargas. Dissertação (mestrado) - Instituto Militar de Engenharia - Rio de Janeiro.

TIAGO, R. P. (2002). Estudo de pontos promissores para instalação de terminais intermodais rodo-ferroviários de containeres no Estado de São Paulo. Dissertação (Mestrado). Escola de Engenharia de São Carlos, Universidade de São Paulo, São Carlos.

TECNOLOGISTICA (2007). Revista Tecnologística. Novo Canal do Panamá terá participação brasileira. Fevereiro, ano XII, nº 135.

TRANSPORTES (2006) - Ministério dos Transportes. Disponível em $<$ http://www.transportes.gov.br>. Acesso em: 05 Nov.

ÜLENGIN, F.; ONSEL, S; AKTAS, E.; KABAK, O. (2006). An integrated transportation decision support system for transportation policy decisions: The case of Turkey. Transportation Research.

VALENTE, A. M.; Passaglia, E.; Novaes, A. G. (1997). Gerenciamento de Transporte e Frotas. 1997. Pioneira Administração e Negócios, São Paulo, SP 
VIVIANI, E. (2003). A utilização de um sistema de informação geográfica como auxílio à gerência de manutenção de estradas rurais não-pavimentadas. Tese (Doutorado). Escola de Engenharia de São Carlos, Universidade de São Paulo, São Carlos.

WACK, P. (1985). Scenarios: uncharted waters ahead. Harvard Business Review, p. 72-89, Sept./Oct.

WINSTON, W. (1995). Operations Research: Applications and Algorithms, 3 ed., Ed. Duxbury. Wadsworth, CA.

WRIGHT, C. L. (1980). Análise econômica de transporte e armazenagem de grãos: estudo do corredor de exportação de Paranaguá. Brasília: GEIPOT. 


\section{APÊNDICE $A$ - custos do bitrem de 7 eixos}

\section{CUSTOS OPERACIONAIS RODOVIÁRIOS PARA BITREM DE 7 EIXOS}

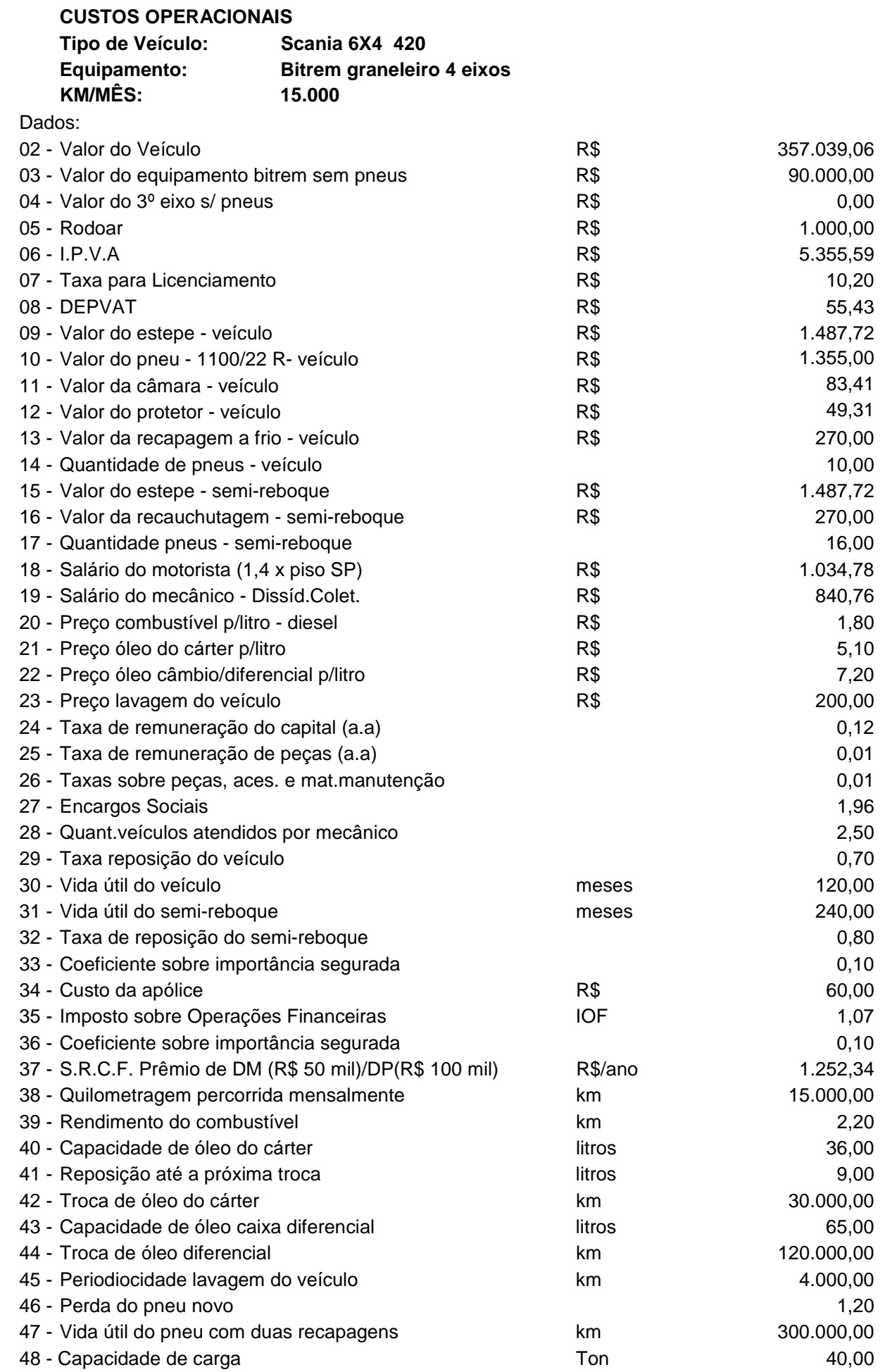


A - Custos Fixos Mensais : $(a+b+c+d+e+f+g+h+i+j)$ Custos Fixos por km: (A/km mensal)

a - Remuneração de capital

b - Salário do motorista

$5.111,63$

c - Salário de oficina

$2.030,96$

660,06

d - Reposição do veículo

e - Reposição do semi-reboque

300,00

$\mathrm{f}$ - Licenciamento

g - Seguro do casco do veículo

$\mathrm{h}$ - Seguro do casco do equipamento

$1.009,95$

i - Seguro de responsabilidade civil facultativa

111,67

B - Custos Variáveis: $(a+b+c+d+e)$

a - Peças, acessórios e materiais de manutenção

b - Combustíveis

c - Lubrificantes

d - Lavagem e lubrificação

e - Pneus

C - Custo Total por Quilômetro

01 - Valor do veículo

$357.039,06$

02 - Rodoar

$1.000,00$

03 - Valor do semi-reboque

$90.000,00$

04 - Valor do $3^{\circ}$ eixo s/pneus

0,00

05 - Quantidade de pneus - semi-reboque

16,00

06 - Valor do pneu do semi-reboque

$1.355,00$

83,41

07 - Valor da câmara do semi-reboque

49,31

09 - Valor Total $(1+2+3+4+(5 \times(6+7+8)))$

$471.842,58$

10 - Taxa de remuneração do capital (a.a)

0,12

11 - Valor anual da remuneração do capital

$56.621,11$

12 - Taxa de remuneração de peças (a.a)

0,01

13 - Valor anual de remuneração de peças - $(9 \times 12)$ 
08 - Taxa reposição do veículo 
01 - Valor do veículo

$357.039,06$

02 - Quantidade de pneus - veículo

10,00

03 - Valor do pneu - veículo

$1.355,00$

04 - Valor da câmara - veículo

83,41

05 - Valor do protetor - veículo

49,31

06 - Valor do semi-reboque sem pneus

$90.000,00$

07 - Valor do $3^{\circ}$ eixo s/pneus

0,00

08 - Rodoar

$1.000,00$

09 - Taxa sobre peças, acessórios mat. de manutenção

10 - Quilometragem percorrida mensalmente

$15.000,00$

b - Combustível: (1:2)

01 - Preço do combustível por litro

02 - Rendimento do combustível

2,20

c - Lubrificantes: $((1 \times(2+3)): 4)+((5 \times 6): 7)$

01 - Preço do óleo de cárter p/ litro

02 - Capacidade de óleo do cárter

36,00

03 - Reposição até a próximo troca

9,00

04 - Troca de óleo do cárter

$30.000,00$

05 - Preço do óleo de câmbio/diferencial p/ litro

7,20

06 - Capacidade de óleo do diferencial

65,00

07 - Troca de óleo do diferencial

$120.000,00$

d - Lavagem e lubrificação: (1:2)

01 - Preço de lavagem do veículo

e - Pneus: $((1+2+3) \times 5 \times 6+(8 \times 4 \times 5)): 7$

01 - Valor do pneu

$1.355,00$

02 - Valor da câmara

03 - Valor do protetor

49,31

04 - Valor da recauchutagem

270,00

05 - Quantidades de pneus - veículo mais semi-reboque

26,00

06 - Perda de pneu novo

1,20

07 - Vida útil do pneu

$300.000,00$

08 - Número de recapagens 


\section{APÊNDICE B - custos do comboio Tietê-Paraná}

\section{Custos no transporte hidroviário - Tietê-Paraná}

\section{Comboio tipo: Tietê - Paraná \\ Empurrador: $900 \mathrm{hp}$ \\ Barcaças: 4 × 1.000 tonelada}

\section{Parâmetros de custo} ESTÁTICOS

Número de empurradores

Número de chatas

Custo de aquisação do empurrador

Custo de aquisação da chatas

Taxa de retorno do capital

Valor residual do custo de aquisição

Vida útil do empurrador

Vida útil das chatas

Capacidade de carga do comboio

Potência instalada do motor

Custo do combustível

Custo do lubrificante

Consumo de combustível por dia

Consumo do lubrificante por dia

Taxa de seguro anual do empurrador

Taxa de seguro anual das chatas

Percentual do custo de manutenção do empurrador

Percentual do custo de manutenção das chatas

Número de tripulantes

Salário total da tripulação

Encargos sociais

Custo da alimentação diária por tripulante

Taxa de lucro

Custo de Administração

\section{DINÂMICOS}

Dias de operação por ano

Fator de utilização potência motor

Número de viagens

Total da carga transportada no período

Custo Operacional Diário do Comboio

Custo Diário do Comboio Parado

Custo Diário por Tonelada

Custo por Quilômetro

A - Custo de Capital Anual

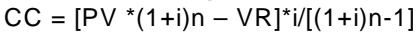

B - Custo do Seguro Anual

$\mathrm{CS}=\mathrm{KS}{ }^{*} \mathrm{PV}$

C - Custo Anual de Tripulação

$\mathrm{CTR}=\mathrm{Nt}^{\star} \mathrm{SM}^{\star} \mathrm{FES}{ }^{*} 12$

D - Custo de alimentação Anual

$\mathrm{CA}=\mathrm{Nt} \mathrm{DAA}^{\star} 360$

E - Custo de Manutenção e Reparo Anual

$\mathrm{CMR}=\mathrm{KMR} * \mathrm{PV}$

F - Custo de Administração Anual

$C A D=K A D *(C T R+C A+C M R)$

G - Custo Anual de Combustível, Lubrificantes e outros $C C L=C O D * P C * T O P * 1,05$

H - Custo Anual de rastreamento
Valor

1,00

4,00

$2.790 .000,00$

$600.000,00$

0,12

0,10

20,00

20,00

$4.000,00$

900,00

1,80

$5,00 \quad \mathrm{R} \$ / 1$

4.368,00 litro/dia

10,56 litro/dia

$0,02 \%$

$0,02 \%$

$0,04 \%$

$0,025 \%$

8,00

$18.595,00 \quad \mathrm{R} \$$

$2,10 \quad \%$

$10,00 \quad \mathrm{R} \$$

$15,00 \%$

$35,00 \quad \%$

360,00 dias

$65,00 \%$

$594.000,00$ ton

$\mathrm{R} \$$

$13.403,40$

$\mathrm{R} \$$

$5.147,88$

$\mathrm{R} \$$

3,35

$\mathrm{R} \$$

74,46

R\$ 608.133,24

R\$

$103.800,00$

R\$

$468.594,00$

R\$

$28.800,00$

R\$

$337.350,00$

R\$

$292.160,40$

R\$

$2.971 .987,20$

R\$ 


\section{APÊNDICE C - Custos do comboio Paraguai-Paraná}

\section{Custos no transporte hidroviário - Paraguai-Paraná}

\section{Comboio tipo: Paraguai-Paraná \\ Empurrador: $2.500 \mathrm{hp}$ \\ Barcaças: 9 × 2.000 tonelada}

Parâmetros de custo ESTÁTICOS

Número de empurradores

Número de chatas

Custo de aquisição do empurrador

Custo de aquisição da chatas

Taxa de retorno do capital

Valor residual do custo de aquisição

Vida útil do empurrador

Vida útil das chatas

Capacidade de carga do comboio

Potência instalada do motor

Custo do combustível

Custo do lubrificante

Consumo de combustível por dia

Consumo do lubrificante por dia

Taxa de seguro anual do empurrador

Taxa de seguro anual das chatas

Percentual do custo de manutenção do empurrador

Percentual do custo de manutenção das chatas

Número de tripulantes

Salário total da tripulação

Encargos sociais

Custo da alimentação diária por tripulante

Taxa de lucro

Custo de Administração

\section{DINÂMICOS}

Dias de operação por ano

Fator de utilização potência motor

Número de viagens

Total da carga transportada no período

Custo Operacional Diário do Comboio

Custo Diário do Comboio Parado

Valor

$\begin{array}{rc}1,00 & \\ 9,00 & \\ 10.000 .000,00 & \mathrm{R} \$ \\ 1.000 .000,00 & \mathrm{R} \$ \\ 0,12 & \% \\ 0,10 & \% \\ 20,00 & \text { anos } \\ 20,00 & \text { anos } \\ 18.000,00 & \text { ton } \\ 2.500,00 & \mathrm{hp} \\ 1,80 & \mathrm{R} \$ / \text { litro } \\ 5,00 & \mathrm{R} \$ / \text { litro } \\ 11.472,00 & \text { litro/dia } \\ 20,00 & \text { litro/dia } \\ 0,02 & \% \\ 0,02 & \% \\ 0,04 & \% \\ 0,025 & \% \\ 10,00 & \\ 21.895,00 & \mathrm{R} \$ \\ 2,10 & \% \\ 10,00 & \mathrm{R} \$ \\ 15,00 & \% \\ 35,00 & \% \\ & \\ 360,00 & \text { dias } \\ 65,00 & \% \\ 1,00 & \\ 594.000,00 & \text { ton }\end{array}$

$36.605,54$

$14.923,46$

2,03

190,65

Custo por Quilômetro

$2.517 .327,14$

A - Custo de Capital Anual

$C C=[P V *(1+i) n-V R]^{*} / /[(1+i) n-1]$

B - Custo do Seguro Anual

$\mathrm{CS}=\mathrm{KS}{ }^{*} \mathrm{PV}$

C - Custo Anual de Tripulação

$\mathrm{CTR}=\mathrm{Nt}^{\star} \mathrm{SM}^{\star} \mathrm{FES} \mathrm{S}^{\star} 12$

$D$ - Custo de alimentação Anual

$\mathrm{CA}=\mathrm{N} \mathrm{t}^{\star} \mathrm{DA} A^{\star} 360$

E - Custo de Manutenção e Reparo Anual

$\mathrm{CMR}=\mathrm{KMR}^{*} \mathrm{PV}$

F - Custo de Administração Anual

$C A D=K A{ }^{\star}(C T R+C A+C M R)$

G - Custo Anual de Combustível, Lubrificantes e outros

$\mathrm{CCL}=\mathrm{COD}^{*} \mathrm{PC} \mathrm{C}^{*} \mathrm{TOP}{ }^{\star} 1,05$

$\mathrm{H}$ - Custo Anual de rastreamento
Unidade

on

$\$$ /litro

dias

ton 


\section{APÊNDICE D - Custos para o Pólo de Chapadão do Sul com bitrem de 7 eixos}

\section{CUSTOS DE TRANSPORTE POR ITINERÁRIOS - 0\% RETORNO}

\section{TRANSPORTE DE SOJA}

REGIÃO NORTE - POLO CHAPADÃO DO SUL

\begin{tabular}{|c|c|c|c|c|c|c|c|c|c|c|c|c|c|}
\hline \multirow{2}{*}{\multicolumn{8}{|c|}{ REGIAO NORIE - POLO CHAPADAO DO SUL }} & \multirow{2}{*}{\multicolumn{3}{|c|}{ Tarifas (R\$ por Tonelada) }} & \multicolumn{3}{|c|}{ Bitrem 7 eixos } \\
\hline & & & & & & & & & & & Custo Total & & Participação \\
\hline Cenários & Modal (is) & Trecho(s) & Frete/Km & Peso $(t)$ & Km & Ponta (t) & Pedágio & Transbordo & Frete & Total & por tonelada & $\%$ & nos custos \\
\hline 1 & Rodoviário & Chapadão do Sul - Santos & 2,37 & 40 & 1.000 & 0,00 & 793,80 & 0,00 & 138,25 & 138,25 & 138,25 & $49 \%$ & $100 \%$ \\
\hline & Rodoviário & Chapadão do Sul - Bataguassu & 2,37 & 40 & 452 & 0,00 & 0,00 & 0,00 & 53,52 & 53,52 & & & $44 \%$ \\
\hline 3 & Hidroviário & Batagassu - Pederneiras & 74,46 & 4.000 & 605 & 0,00 & 0,00 & 3,00 & 22,53 & 25,53 & 121,04 & $30 \%$ & $21 \%$ \\
\hline & Ferroviário & Pederneiras - Santos & 403,98 & 5.200 & 502 & 0,00 & 0,00 & 3,00 & 39,00 & 42,00 & & & $35 \%$ \\
\hline & Rodoviário & Chapadão do Sul - São Simão & 2,37 & 40 & 321 & 0,00 & 0,00 & 0,00 & 38,01 & 38,01 & & & $36 \%$ \\
\hline 3 & Hidroviário & São Simão - Pederneiras & 74,46 & 4.000 & 640 & 0,00 & 0,00 & 3,00 & 23,83 & 26,83 & 106,84 & $15 \%$ & $25 \%$ \\
\hline & Ferroviário & Pederneiras - Santos & 403,98 & 5.200 & 502 & 0,00 & 0,00 & 3,00 & 39,00 & 42,00 & & & $39 \%$ \\
\hline 4 & Ferroviário & Chapadão do Sul - Santos & 519,37 & 7.000 & 1.182 & 20,84 & 0,00 & 3,00 & 87,70 & 111,54 & 111,54 & $20 \%$ & $100 \%$ \\
\hline & Rodoviário & Chapadão do Sul - Três Lagoas & 2,37 & 40 & 317 & 0,00 & 0,00 & 0,00 & 37,53 & 37,53 & & & $40 \%$ \\
\hline 3 & Hidroviário & Três Lagoas - Pederneiras & 74,46 & 4.000 & 281 & 0,00 & 0,00 & 3,00 & 10,46 & 13,46 & 93,00 & $0 \%$ & $14 \%$ \\
\hline & Ferroviário & Pederneiras - Santos & 403,98 & 5.200 & 502 & 0,00 & 0,00 & 3,00 & 39,00 & 42,00 & , & 070 & $45 \%$ \\
\hline 1 & Rodoviário & Chapadão do Sul - Paranaguá & 2,37 & 40 & 1.220 & 0,00 & 114,80 & 0,00 & 147,33 & 147,33 & 147,33 & $58 \%$ & $100 \%$ \\
\hline 2 & Rodoviário & Chapadão do Sul - Cascavel & 2,37 & 40 & 988 & 0,00 & 0,00 & 0,00 & 116,99 & 116,99 & & & $72 \%$ \\
\hline 2 & Ferroviário & Cascavel - Paranaguá & 122,52 & 2.100 & 737 & 0,00 & 0,00 & 3,00 & 43,00 & 46,00 & 162,99 & $15 \%$ & $28 \%$ \\
\hline & Rodoviário & Chapadão do Sul - Campo Grande & 2,37 & 40 & 369 & 0,00 & 0,00 & 0,00 & 43,69 & 43,69 & & & $39 \%$ \\
\hline 5 & Ferroviário & Campo Grande - Corumbá & 86,58 & 1.250 & 462 & 0,00 & 0,00 & 3,00 & 32,00 & 35,00 & 111,03 & $19 \%$ & $32 \%$ \\
\hline & Hidroviário & Corumbá - Nova Palmira & 190,65 & 18.000 & 2.770 & 0,00 & 0,00 & 3,00 & 29,34 & 32,34 & & & $29 \%$ \\
\hline & Rodoviário & Chapadão do Sul - Corumbá & 2,37 & 40 & 802 & 0,00 & 40,00 & 0,00 & 95,96 & 95,96 & & & $75 \%$ \\
\hline 6 & Hidroviário & Corumbá - Nova Palmira & 190,65 & 18.000 & 2.770 & 0,00 & 0,00 & 3,00 & 29,34 & 32,34 & 128,30 & $38 \%$ & $25 \%$ \\
\hline 6 & Rodoviário & Chapadão do Sul - Porto Murtinho & 2,37 & 40 & 792 & 0,00 & 0,00 & 0,00 & 93,78 & 93,78 & 12042 & $29 \%$ & $78 \%$ \\
\hline 6 & Hidroviário & Porto Murtinho - Nova Palmira & 190,65 & 18.000 & 2.232 & 0,00 & 0,00 & 3,00 & 23,64 & 26,64 & 120,42 & $29 \%$ & $22 \%$ \\
\hline 2 & Rodoviário & Chapadão do Sul - P. Epitácio & 2,37 & 40 & 542 & 0,00 & 0,00 & 0,00 & 64,18 & 64,18 & 11268 & $21 \%$ & $57 \%$ \\
\hline 2 & Ferroviário & P. Epitácio - Santos & 175,00 & 2.500 & 650 & 0,00 & 0,00 & 3,00 & 45,50 & 48,50 & 112,68 & $21 \%$ & $43 \%$ \\
\hline & Rodoviário & Chapadão do Sul - Campo Grande & 2,37 & 40 & 369 & 0,00 & 0,00 & 0,00 & 43,69 & 43,69 & 20 & $30 \%$ & $36 \%$ \\
\hline 2 & Ferroviário & Campo Grande - Paranaguá & 122,52 & 2.100 & 1.270 & 0,00 & 0,00 & 3,00 & 74,10 & 77,10 & 120,79 & $30 \%$ & $64 \%$ \\
\hline
\end{tabular}




\section{CUSTOS DE TRANSPORTE POR ITINERÁRIOS - 40\% RETORNO}

\section{TRANSPORTE DE SOJA}

REGIÃO NORTE - POLO CHAPADÃO DO SUL

\begin{tabular}{|c|c|c|c|c|c|c|c|c|c|c|c|c|c|}
\hline \multirow[b]{2}{*}{ Cenários } & \multirow[b]{2}{*}{ Modal (is) } & \multirow[b]{2}{*}{ Trecho(s) } & \multirow[b]{2}{*}{ Frete/Km } & \multirow[b]{2}{*}{ Peso (ton) } & \multirow[b]{2}{*}{ Km } & \multirow[b]{2}{*}{ Ponta $(t)$} & \multirow[b]{2}{*}{ Pedágio } & \multicolumn{3}{|c|}{ Tarifas (RS por Tonelada) } & \multirow{2}{*}{$\begin{array}{c}\text { Custo Total } \\
\text { por tonelada }\end{array}$} & \multirow{2}{*}{$\%$} & \multirow{2}{*}{$\begin{array}{l}\text { Participação } \\
\text { nos custos }\end{array}$} \\
\hline & & & & & & & & \begin{tabular}{|l|} 
Transbordo \\
\end{tabular} & Frete & Total & & & \\
\hline 1 & Rodoviário & Chapadão do Sul - Santos & 2,37 & 40 & 1.000 & 0,00 & 661,00 & 0,00 & 111,25 & 111,25 & 111,25 & $30 \%$ & $100 \%$ \\
\hline \multirow{3}{*}{3} & Rodoviário & Chapadão do Sul - Bataguassu & 2,37 & 40 & 452 & 0,00 & 0,00 & 0,00 & 42,82 & 42,82 & \multirow{3}{*}{110,34} & \multirow{3}{*}{$29 \%$} & $39 \%$ \\
\hline & Hidroviário & Batagassu - Pederneiras & 74,46 & 4.000 & 605 & 0,00 & 0,00 & 3,00 & 22,53 & 25,53 & & & $23 \%$ \\
\hline & Ferroviário & Pederneiras - Santos & 403,98 & 5.200 & 502 & 0,00 & 0,00 & 3,00 & 39,00 & 42,00 & & & $38 \%$ \\
\hline \multirow{3}{*}{3} & Rodoviário & Chapadão do Sul - São Simão & 2,37 & 40 & 321 & 0,00 & 0,00 & 0,00 & 30,41 & 30,41 & \multirow{3}{*}{99,24} & \multirow{3}{*}{$16 \%$} & $31 \%$ \\
\hline & Hidroviário & São Simão - Pederneiras & 74,46 & 4.000 & 640 & 0,00 & 0,00 & 3,00 & 23,83 & 26,83 & & & $27 \%$ \\
\hline & Ferroviário & Pederneiras - Santos & 403,98 & 5.200 & 502 & 0,00 & 0,00 & 3,00 & 39,00 & 42,00 & & & $42 \%$ \\
\hline 4 & Ferroviário & Chapadão do Sul - Santos & 519,37 & 7.000 & 1.182 & 20,84 & 0,00 & 3,00 & 87,70 & 111,54 & 111,54 & $30 \%$ & $100 \%$ \\
\hline \multirow{3}{*}{3} & Rodoviário & Chapadão do Sul - Três Lagoas & 2,37 & 40 & 317 & 0,00 & 0,00 & 0,00 & 30,03 & 30,03 & \multirow{3}{*}{85,49} & \multirow{3}{*}{$0 \%$} & $35 \%$ \\
\hline & Hidroviário & Três Lagoas - Pederneiras & 74,46 & 4.000 & 281 & 0,00 & 0,00 & 3,00 & 10,46 & 13,46 & & & $16 \%$ \\
\hline & Ferroviário & Pederneiras - Santos & 403,98 & 5.200 & 502 & 0,00 & 0,00 & 3,00 & 39,00 & 42,00 & & & $49 \%$ \\
\hline 1 & Rodoviário & Chapadão do Sul - Paranaguá & 2,37 & 40 & 1.220 & 0,00 & 91,84 & 0,00 & 117,86 & 117,86 & 117,86 & $38 \%$ & $100 \%$ \\
\hline \multirow{2}{*}{2} & Rodoviário & Chapadão do Sul - Cascavel & 2,37 & 40 & 988 & 0,00 & 0,00 & 0,00 & 93,59 & 93,59 & \multirow{2}{*}{139,59} & \multirow{2}{*}{$63 \%$} & $67 \%$ \\
\hline & Ferroviário & Cascavel - Paranaguá & 122,52 & 2.100 & 737 & 0,00 & 0,00 & 3,00 & 43,00 & 46,00 & & & $33 \%$ \\
\hline \multirow{3}{*}{5} & Rodoviário & Chapadão do Sul - Campo Grande & 2,37 & 40 & 369 & 0,00 & 0,00 & 0,00 & 34,95 & 34,95 & \multirow{3}{*}{102,29} & \multirow{3}{*}{$20 \%$} & $34 \%$ \\
\hline & Ferroviário & Campo Grande - Corumbá & 86,58 & 1.250 & 462 & 0,00 & 0,00 & 3,00 & 32,00 & 35,00 & & & $34 \%$ \\
\hline & Hidroviário & Corumbá - Nova Palmira & 190,65 & 18.000 & 2.770 & 0,00 & 0,00 & 3,00 & 29,34 & 32,34 & & & $32 \%$ \\
\hline \multirow{2}{*}{6} & Rodoviário & Chapadão do Sul - Corumbá & 2,37 & 40 & 788 & 0,00 & 32,00 & 0,00 & 75,44 & 75,44 & \multirow{2}{*}{107,78} & $26 \%$ & $70 \%$ \\
\hline & Hidroviário & Corumbá - Nova Palmira & 190,65 & 18.000 & 2.770 & 0,00 & 0,00 & 3,00 & 29,34 & 32,34 & & $26 \%$ & $30 \%$ \\
\hline & Rodoviário & Chapadão do Sul - Porto Murtinho & 2,37 & 40 & 772 & 0,00 & 0,00 & 0,00 & 73,13 & 73,13 & ד & 170 & $73 \%$ \\
\hline 6 & Hidroviário & Porto Murtinho - Nova Palmira & 190,65 & 18.000 & 2.232 & 0,00 & 0,00 & 3,00 & 23,64 & 26,64 & $99,7 /$ & $1 / \%$ & $27 \%$ \\
\hline 2 & Rodoviário & Chapadão do Sul - P. Epitácio & 2,37 & 40 & 542 & 0,00 & 0,00 & 0,00 & 51,34 & 51,34 & 9984 & $170 \%$ & $51 \%$ \\
\hline 2 & Ferroviário & P. Epitácio - Santos & 175,00 & 2.500 & 650 & 0,00 & 0,00 & 3,00 & 45,50 & 48,50 & 99,84 & $17 \%$ & $49 \%$ \\
\hline 2 & Rodoviário & Chapadão do Sul - Campo Grande & 2,37 & 40 & 369 & 0,00 & 0,00 & 0,00 & 34,95 & 34,95 & 25 & 210 & $31 \%$ \\
\hline 2 & Ferroviário & Campo Grande - Paranaguá & 122,52 & 2.100 & 1.270 & 0,00 & 0,00 & 3,00 & 74,10 & 77,10 & 112,05 & $31 \%$ & $69 \%$ \\
\hline
\end{tabular}


CUSTOS DE TRANSPORTE POR ITINERÁRIOS - 60\% RETORNO

\section{TRANSPORTE DE SOJA}

REGIÄO NORTE - POLO CHAPADÄO DO SUL

\begin{tabular}{|c|c|c|c|c|c|c|c|c|c|c|c|c|c|}
\hline \multirow{2}{*}{ Cenários } & \multirow[b]{2}{*}{ Modal (is) } & \multirow[b]{2}{*}{ Trecho(s) } & \multirow[b]{2}{*}{ Frete/Km } & \multirow[b]{2}{*}{ Peso (ton) } & \multirow[b]{2}{*}{$K m$} & \multirow[b]{2}{*}{ Ponta $(t)$} & \multirow[b]{2}{*}{ Pedágio } & \multicolumn{3}{|c|}{ Tarifas (R\$ por Tonelada) } & \multirow{2}{*}{$\begin{array}{c}\text { Custo Total } \\
\text { por tonelada }\end{array}$} & \multirow{2}{*}{$\%$} & \multirow{2}{*}{\begin{tabular}{|l} 
Participação \\
nos custos
\end{tabular}} \\
\hline & & & & & & & & Transbordo & Frete & Total & & & \\
\hline 1 & Rodoviário & Chapadão do Sul - Santos & 2,37 & 40 & 1.000 & 0,00 & 539,98 & 0,00 & 96,38 & 96,38 & 96,38 & $18 \%$ & $100 \%$ \\
\hline \multirow{3}{*}{3} & Rodoviário & Chapadão do Sul - Bataguassu & 2,37 & 40 & 452 & 0,00 & 0,00 & 0,00 & 37,46 & 37,46 & \multirow{3}{*}{104,99} & \multirow{3}{*}{$28 \%$} & $36 \%$ \\
\hline & Hidroviário & Batagassu - Pederneiras & 74,46 & 4.000 & 605 & 0,00 & 0,00 & 3,00 & 22,53 & 25,53 & & & $24 \%$ \\
\hline & Ferroviário & Pederneiras - Santos & 403,98 & 5.200 & 502 & 0,00 & 0,00 & 3,00 & 39,00 & 42,00 & & & $40 \%$ \\
\hline \multirow{3}{*}{3} & Rodoviário & Chapadão do Sul - São Simão & 2,37 & 40 & 321 & 0,00 & 0,00 & 0,00 & 26,61 & 26,61 & \multirow{3}{*}{95,43} & \multirow{3}{*}{$17 \%$} & $28 \%$ \\
\hline & Hidroviário & São Simão - Pederneiras & 74,46 & 4.000 & 640 & 0,00 & 0,00 & 3,00 & 23,83 & 26,83 & & & $28 \%$ \\
\hline & Ferroviário & Pederneiras - Santos & 403,98 & 5.200 & 502 & 0,00 & 0,00 & 3,00 & 39,00 & 42,00 & & & $44 \%$ \\
\hline 4 & Ferroviário & Chapadão do Sul - Santos & 519,37 & 7.000 & 1.182 & 20,84 & 0,00 & 3,00 & 87,70 & 111,54 & 111,54 & $36 \%$ & $100 \%$ \\
\hline \multirow{3}{*}{3} & Rodoviário & Chapadão do Sul - Três Lagoas & 2,37 & 40 & 317 & 0,00 & 0,00 & 0,00 & 26,27 & 26,27 & \multirow{3}{*}{81,74} & \multirow{3}{*}{$0 \%$} & $32 \%$ \\
\hline & Hidroviário & Três Lagoas - Pederneiras & 74,46 & 4.000 & 281 & 0,00 & 0,00 & 3,00 & 10,46 & 13,46 & & & $16 \%$ \\
\hline & Ferroviário & Pederneiras - Santos & 403,98 & 5.200 & 502 & 0,00 & 0,00 & 3,00 & 39,00 & 42,00 & & & $51 \%$ \\
\hline 1 & Rodoviário & Chapadão do Sul - Paranaguá & 2,37 & 40 & 1.220 & 0,00 & 80,36 & 0,00 & 103,13 & 103,13 & 103,13 & $26 \%$ & $100 \%$ \\
\hline \multirow{2}{*}{2} & Rodoviário & Chapadão do Sul - Cascavel & 2,37 & 40 & 988 & 0,00 & 0,00 & 0,00 & 81,89 & 81,89 & \multirow{2}{*}{127,89} & \multirow[b]{2}{*}{$56 \%$} & $64 \%$ \\
\hline & Ferroviário & Cascavel - Paranaguá & 122,52 & 2.100 & 737 & 0,00 & 0,00 & 3,00 & 43,00 & 46,00 & & & $36 \%$ \\
\hline \multirow{3}{*}{5} & Rodoviário & Chapadão do Sul - Campo Grande & 2,37 & 40 & 369 & 0,00 & 0,00 & 0,00 & 30,58 & 30,58 & \multirow{3}{*}{97,92} & \multirow{3}{*}{$20 \%$} & $31 \%$ \\
\hline & Ferroviário & Campo Grande - Corumbá & 86,58 & 1.250 & 462 & 0,00 & 0,00 & 3,00 & 32,00 & 35,00 & & & $36 \%$ \\
\hline & Hidroviário & Corumbá - Nova Palmira & 190,65 & 18.000 & 2.770 & 0,00 & 0,00 & 3,00 & 29,34 & 32,34 & & & $33 \%$ \\
\hline \multirow[b]{2}{*}{6} & Rodoviário & Chapadão do Sul - Corumbá & 2,37 & 40 & 802 & 0,00 & 28,00 & 0,00 & 67,17 & 67,17 & \multirow{2}{*}{99,51} & 200 & $68 \%$ \\
\hline & Hidroviário & Corumbá - Nova Palmira & 190,65 & 18.000 & 2.770 & 0,00 & 0,00 & 3,00 & 29,34 & 32,34 & & $22 \%$ & $32 \%$ \\
\hline 6 & Rodoviário & Chapadão do Sul - Porto Murtinho & 2,37 & 40 & 792 & 0,00 & 0,00 & 0,00 & 65,64 & 65,64 & & & $71 \%$ \\
\hline 6 & Hidroviário & Porto Murtinho - Nova Palmira & 190,65 & 18.000 & 2.232 & 0,00 & 0,00 & 3,00 & 23,64 & 26,64 & 92,29 & $13 \%$ & $29 \%$ \\
\hline 2 & Rodoviário & Chapadão do Sul - P. Epitácio & 2,37 & 40 & 542 & 0,00 & 0,00 & 0,00 & 44,92 & 44,92 & & & $48 \%$ \\
\hline 2 & Ferroviário & P. Epitácio - Santos & 175,00 & 2.500 & 650 & 0,00 & 0,00 & 3,00 & 45,50 & 48,50 & 93,42 & $14 \%$ & $52 \%$ \\
\hline 2 & Rodoviário & Chapadão do Sul - Campo Grande & 2,37 & 40 & 369 & 0,00 & 0,00 & 0,00 & 30,58 & 30,58 & 10768 & $32 \%$ & $28 \%$ \\
\hline 2 & Ferroviário & Campo Grande - Paranaguá & 122,52 & 2.100 & 1.270 & 0,00 & 0,00 & 3,00 & 74,10 & 77,10 & 101,68 & & $72 \%$ \\
\hline
\end{tabular}




\section{APÊNDICE E - Custos para o Pólo de Campo Grande com bitrem de 7 eixos}

\section{CUSTOS DE TRANSPORTE POR ITINERÁRIOS - 0\% RETORNO}

TRANSPORTE DE SOJA

\section{REGIÃO CENTRAL - POLO CAMPO GRANDE}

\begin{tabular}{|l|l|l|}
\hline Cenários & Modal (is) & Trecho(s) \\
\hline
\end{tabular}

\begin{tabular}{|c|c|c|c|c|c|c|}
\hline Cenários & Modal (is) & Trecho (s) & Frete/Km & Peso (ton) & $\overline{K m}$ & Ponta F \\
\hline$\overline{1}$ & Rodoviário & Campo Grande - Santos & 2,37 & 40 & 1.155 & $\overline{0,}$ \\
\hline$\overline{4}$ & Ferroviário & Campo Grande - Santos & 172,66 & 2.500 & 1.306 & $\overline{13}$ \\
\hline \multirow{2}{*}{6} & Rodoviário & Campo Grande - Pto Murtinho & 2,37 & 40 & 450 & 0, \\
\hline & Hidroviário & Pto Murtinho - Nova Palmira & 190,65 & 18.000 & 2.232 & 0, \\
\hline \multirow{3}{*}{3} & Rodoviário & Campo Grande - Bataguassu & 2,37 & 40 & 373 & 0 \\
\hline & Hidroviário & Batagassu - Pederneiras & 74,46 & 4.000 & 605 & 0 \\
\hline & Ferroviário & Pederneiras - Santos & 403,98 & 5.200 & 502 & \\
\hline \multirow{3}{*}{3} & Rodoviário & Campo Grande - Três Lagoas & 2,37 & 40 & 350 & $\underline{0}$ \\
\hline & Hidroviário & Três Lagoas - Pederneiras & 74,46 & 4.000 & 281 & 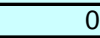 \\
\hline & Ferroviário & Pederneiras - Santos & 403,98 & 5.200 & 502 & 0 \\
\hline 1 & Rodoviário & Campo Grande - Paranaguá & 2,37 & 40 & 1.160 & $\overline{0,}$ \\
\hline \multirow[b]{2}{*}{2} & Rodoviário & Campo Grande - Cascavel & 2,37 & 40 & 683 & $\overline{0}$ \\
\hline & Ferroviário & Cascavel - Paranaguá & 122,52 & 2.100 & 737 & 0 \\
\hline \multirow{2}{*}{7} & Ferroviário & Campo Grande - Corumbá & 86,58 & 1.250 & 462 & $\overline{13}$ \\
\hline & Hidroviário & Corumbá - Nova Palmira & 190,65 & 18.000 & 2.770 & 0 \\
\hline \multirow{2}{*}{2} & Rodoviário & Campo Grande - Chapadão do Sul & 2,37 & 40 & 332 & $\overline{0}$ \\
\hline & Ferroviário & Chapadão do Sul - Santos & 519,37 & 7.000 & 1.182 & \\
\hline \multirow{3}{*}{3} & Rodoviário & Campo Grande - São Simão & 2,37 & 40 & 564 & \\
\hline & Hidroviário & São Simão - Pederneiras & 74,46 & 4.000 & 640 & $\overline{0}$ \\
\hline & Ferroviário & Pederneiras - Santos & 403,98 & 5.200 & 502 & $\overline{0}$ \\
\hline \multirow[b]{2}{*}{2} & Rodoviário & Campo Grande - P. Epitácio & 2,37 & 40 & 410 & $\overline{0}$ \\
\hline & Ferroviário & P. Epitácio - Santos & 175,00 & 2.500 & 650 & 0 \\
\hline \multirow{2}{*}{2} & Rodoviário & Campo Grande - Maringá & 2,37 & 40 & 636 & \\
\hline & Ferroviário & Maringá - Paranaguá & 128,44 & 2.100 & 654 & \\
\hline 4 & Ferroviário & Campo Grande - Paranaguá & 122,52 & 2.100 & 1.270 & $\overline{8}$ \\
\hline
\end{tabular}

\begin{tabular}{|c|c|c|c|c|c|c|c|}
\hline & & & & \multicolumn{3}{|c|}{ Bitrem 7 eixos } \\
\hline & & \multicolumn{3}{|c|}{ Tarifas (R\$ por Tonelada) } & \multirow{2}{*}{$\begin{array}{l}\text { Custo } \\
\text { por tol }\end{array}$} & & \multirow{2}{*}{$\begin{array}{l}\text { Participação } \\
\text { nos custos }\end{array}$} \\
\hline Rd & Pedágio & Transbordo & Frete & Total & & $\%$ & \\
\hline 0,00 & 665,70 & 0,00 & 153,40 & 153,40 & 153,40 & $92 \%$ & $100 \%$ \\
\hline 13,99 & $\overline{0,00}$ & 3,00 & 90,21 & 107,20 & 107,20 & $34 \%$ & $100 \%$ \\
\hline$\overline{0,00}$ & 0,00 & 0,00 & 53,28 & 53,28 & \multirow{2}{*}{79,92} & \multirow{2}{*}{$0 \%$} & $67 \%$ \\
\hline 0,00 & 0,00 & 3,00 & 23,64 & 26,64 & & & $33 \%$ \\
\hline 0,00 & 0,00 & 0,00 & 44,17 & 44,17 & \multirow{3}{*}{111,69} & \multirow{3}{*}{$40 \%$} & $40 \%$ \\
\hline 0,00 & 0,00 & 3,00 & 22,53 & 25,53 & & & $23 \%$ \\
\hline 0,00 & 0,00 & 3,00 & 39,00 & 42,00 & & & $38 \%$ \\
\hline 0,00 & 0,00 & 0,00 & 41,44 & 41,44 & \multirow{3}{*}{96,90} & \multirow{3}{*}{$21 \%$} & $43 \%$ \\
\hline 0,00 & 0,00 & 3,00 & 10,46 & 13,46 & & & $14 \%$ \\
\hline 0,00 & 0,00 & 3,00 & 39,00 & 42,00 & & & $43 \%$ \\
\hline$\overline{0,00}$ & 487,80 & 0,00 & 149,55 & 149,55 & 149,55 & $87 \%$ & $100 \%$ \\
\hline 0,00 & 0,00 & 0,00 & 80,87 & 80,87 & \multirow{2}{*}{126,87} & \multirow{2}{*}{$59 \%$} & $64 \%$ \\
\hline 0,00 & 0,00 & 3,00 & 43,00 & 46,00 & & & $36 \%$ \\
\hline 13,99 & 0,00 & 3,00 & 32,00 & 48,99 & \multirow[b]{2}{*}{81,33} & \multirow{2}{*}{$2 \%$} & $60 \%$ \\
\hline 0,00 & 0,00 & 3,00 & 29,34 & 32,34 & & & $40 \%$ \\
\hline 0,00 & 0,00 & 0,00 & 39,31 & 39,31 & \multirow[b]{2}{*}{130,01} & \multirow{2}{*}{$63 \%$} & $30 \%$ \\
\hline \begin{tabular}{l|l|}
0,00 \\
\end{tabular} & 0,00 & 3,00 & 87,70 & 90,70 & & & $70 \%$ \\
\hline $\begin{array}{l}0,00 \\
\end{array}$ & 0,00 & 0,00 & 66,78 & 66,78 & \multirow{3}{*}{135,61} & \multirow{3}{*}{$70 \%$} & $49 \%$ \\
\hline 0,00 & 0,00 & 3,00 & 23,83 & 26,83 & & & $20 \%$ \\
\hline $\begin{array}{l}0,00 \\
\end{array}$ & 0,00 & 3,00 & 39,00 & 42,00 & & & $31 \%$ \\
\hline \begin{tabular}{l|l}
0,00 \\
\end{tabular} & 0,00 & 0,00 & 48,55 & 48,55 & \multirow{2}{*}{97,05} & \multirow{2}{*}{$21 \%$} & $50 \%$ \\
\hline 0,00 & 0,00 & 3,00 & 45,50 & 48,50 & & & $50 \%$ \\
\hline $\begin{array}{l}0,00 \\
\end{array}$ & 71,40 & 0,00 & 77,09 & 77,09 & \multirow{2}{*}{120,09} & \multirow{2}{*}{$50 \%$} & $64 \%$ \\
\hline 0,00 & 0,00 & 3,00 & 40,00 & 43,00 & & & $36 \%$ \\
\hline & 0,00 & 3,00 & 74,10 & 85,37 & 85,37 & $7 \%$ & $100 \%$ \\
\hline
\end{tabular}


CUSTOS DE TRANSPORTE POR ITINERÁRIOS - 40\% RETORNO

\section{TRANSPORTE DE SOJA}

\section{REGIÃO CENTRAL - POLO CAMPO GRANDE}

\begin{tabular}{|c|c|c|c|c|c|c|c|c|c|c|c|c|c|}
\hline \multicolumn{8}{|c|}{ REGIÃO CENTRAL - POLO CAMPO GRANDE } & \multirow{2}{*}{\multicolumn{3}{|c|}{ Tarifas (R\$ por Tonelada) }} & \multicolumn{3}{|c|}{ Bitrem 7 eixos } \\
\hline & & & & & & & & & & & \multirow{2}{*}{\begin{tabular}{|l|} 
Custo \\
por toneladal
\end{tabular}} & & \multirow{2}{*}{$\begin{array}{l}\text { Participação } \\
\text { nos custos }\end{array}$} \\
\hline Cenários & Modal (is) & Trecho (s) & Frete/Km & Peso (ton) & $K m$ & Ponta Rd & Pedágio & Transbordo & Frete & Total & & $\%$ & \\
\hline 1 & Rodoviário & Campo Grande - Santos & 2,37 & 40 & 1.155 & 0,00 & 528,22 & 0,00 & 122,61 & 122,61 & 122,61 & $77 \%$ & $100 \%$ \\
\hline 4 & Ferroviário & Campo Grande - Santos & 172,66 & 2.500 & 1.306 & 13,99 & 0,00 & 3,00 & 90,20 & 107,19 & 107,19 & $55 \%$ & $100 \%$ \\
\hline \multirow{2}{*}{6} & Rodoviário & Campo Grande - Pto Murtinho & 2,37 & 40 & 450 & 0,00 & 0,00 & 0,00 & 42,63 & 42,63 & \multirow{2}{*}{69,27} & \multirow{2}{*}{$0 \%$} & $62 \%$ \\
\hline & Hidroviário & Pto Murtinho - Nova Palmira & 190,65 & 18.000 & 2.232 & 0,00 & 0,00 & 3,00 & 23,64 & 26,64 & & & $38 \%$ \\
\hline \multirow{3}{*}{3} & Rodoviário & Campo Grande - Bataguassu & 2,37 & 40 & 373 & 0,00 & 0,00 & 0,00 & 35,33 & 35,33 & \multirow{3}{*}{102,86} & \multirow{3}{*}{$48 \%$} & $34 \%$ \\
\hline & Hidroviário & Batagassu - Pederneiras & 74,46 & 4.000 & 605 & 0,00 & 0,00 & 3,00 & 22,53 & 25,53 & & & $25 \%$ \\
\hline & Ferroviário & Pederneiras - Santos & 403,98 & 5.200 & 502 & 0,00 & 0,00 & 3,00 & 39,00 & 42,00 & & & $41 \%$ \\
\hline \multirow{3}{*}{3} & Rodoviário & Campo Grande - Três Lagoas & 2,37 & 40 & 350 & 0,00 & 0,00 & 0,00 & 33,15 & 33,15 & \multirow{3}{*}{88,62} & \multirow{3}{*}{$28 \%$} & $37 \%$ \\
\hline & Hidroviário & Três Lagoas - Pederneiras & 74,46 & 4.000 & 281 & 0,00 & 0,00 & 3,00 & 10,46 & 13,46 & & & $15 \%$ \\
\hline & Ferroviário & Pederneiras - Santos & 403,98 & 5.200 & 502 & 0,00 & 0,00 & 3,00 & 39,00 & 42,00 & & & $47 \%$ \\
\hline 1 & Rodoviário & Campo Grande - Paranaguá & 2,37 & 40 & 1.160 & 0,00 & 402,68 & 0,00 & 119,95 & 119,95 & 119,95 & $73 \%$ & $\overline{100 \%}$ \\
\hline \multirow{2}{*}{2} & Rodoviário & Campo Grande - Cascavel & 2,37 & 40 & 640 & 0,00 & 0,00 & 0,00 & 60,62 & 60,62 & \multirow{2}{*}{106,62} & \multirow{2}{*}{$54 \%$} & $57 \%$ \\
\hline & Ferroviário & Cascavel - Paranaguá & 122,52 & 2.100 & 737 & 0,00 & 0,00 & 3,00 & 43,00 & 46,00 & & & $43 \%$ \\
\hline \multirow{2}{*}{7} & Ferroviário & Campo Grande - Corumbá & 86,58 & 1.250 & 462 & 13,99 & 0,00 & 3,00 & 32,00 & 48,99 & \multirow{2}{*}{81,33} & \multirow{2}{*}{$17 \%$} & $60 \%$ \\
\hline & Hidroviário & Corumbá - Nova Palmira & 190,65 & 18.000 & 2.770 & 0,00 & 0,00 & 3,00 & 29,34 & 32,34 & & & $40 \%$ \\
\hline \multirow{2}{*}{2} & Rodoviário & Campo Grande - Chapadão do Sul & 2,37 & 40 & 332 & 0,00 & 0,00 & 0,00 & 31,45 & 31,45 & \multirow{2}{*}{122,15} & \multirow{2}{*}{$76 \%$} & $26 \%$ \\
\hline & Ferroviário & Chapadão do Sul - Santos & 519,37 & 7.000 & 1.182 & 0,00 & 0,00 & 3,00 & 87,70 & 90,70 & & & $74 \%$ \\
\hline \multirow{3}{*}{3} & Rodoviário & Campo Grande - São Simão & 2,37 & 40 & 350 & 0,00 & 0,00 & 0,00 & 33,15 & 33,15 & \multirow{3}{*}{101,98} & \multirow{3}{*}{$47 \%$} & $33 \%$ \\
\hline & Hidroviário & São Simão - Pederneiras & 74,46 & 4.000 & 640 & 0,00 & 0,00 & 3,00 & 23,83 & 26,83 & & & $26 \%$ \\
\hline & Ferroviário & Pederneiras - Santos & 403,98 & 5.200 & 502 & 0,00 & 0,00 & 3,00 & 39,00 & 42,00 & & & $41 \%$ \\
\hline \multirow[b]{2}{*}{2} & Rodoviário & Campo Grande - P. Epitácio & 2,37 & 40 & 410 & 0,00 & 0,00 & 0,00 & 38,84 & 38,84 & \multirow{2}{*}{87,34} & & $44 \%$ \\
\hline & Ferroviário & P. Epitácio - Santos & 175,00 & 2.500 & 650 & 0,00 & 0,00 & 3,00 & 45,50 & 48,50 & & $26 \%$ & $56 \%$ \\
\hline 2 & Rodoviário & Campo Grande - Maringá & 2,37 & 40 & 636 & 0,00 & 57,12 & 0,00 & 61,67 & 61,67 & 10467 & 51\% & $59 \%$ \\
\hline 2 & Ferroviário & Maringá - Paranaguá & 128,44 & 2.100 & 654 & 0,00 & 0,00 & 3,00 & 40,00 & 43,00 & 104,67 & $51 \%$ & $41 \%$ \\
\hline$\overline{4}$ & Ferroviário & Campo Grande - Paranaguá & 122,52 & 2.100 & 1.270 & 8,28 & 0,00 & 3,00 & 74,10 & 85,37 & 85,37 & $23 \%$ & $100 \%$ \\
\hline
\end{tabular}


CUSTOS DE TRANSPORTE POR ITINERÁRIOS - 60\% RETORNO

TRANSPORTE DE SOJA

REGIÃO CENTRAL - POLO CAMPO GRANDE

\begin{tabular}{|c|c|c|c|c|c|c|c|c|c|c|c|c|c|}
\hline & \multirow{2}{*}{\multicolumn{3}{|c|}{ Tarifas (R\$ por Tonelada) }} & \\
\hline & & & & & & & & & & & Custo & & Participação \\
\hline Cenários & Modal (is) & Trecho(s) & Frete/Km & Peso (ton) & Km & Ponta Rd & Pedágio & \begin{tabular}{|l|} 
Transbordo \\
\end{tabular} & Frete & Total & por tonelada & $\%$ & nos custos \\
\hline 1 & Rodoviário & Campo Grande - Santos & 2,37 & 40 & 1.155 & 0,00 & 450,80 & 0,00 & 107,00 & 107,00 & 107,00 & $67 \%$ & $100 \%$ \\
\hline 4 & Ferroviário & Campo Grande - Santos & 172,66 & 2.500 & 1.306 & 13,99 & 0,00 & 3,00 & 90,20 & 107,19 & 107,19 & $68 \%$ & $100 \%$ \\
\hline 6 & Rodoviário & Campo Grande - Pto Murtinho & 2,37 & 40 & 450 & 0,00 & 0,00 & 0,00 & 37,30 & 37,30 & & & $58 \%$ \\
\hline 6 & Hidroviário & Pto Murtinho - Nova Palmira & 190,65 & 18.000 & 2.232 & 0,00 & 0,00 & 3,00 & 23,64 & 26,64 & 63,94 & $0 \%$ & $42 \%$ \\
\hline & Rodoviário & Campo Grande - Bataguassu & 2,37 & 40 & 373 & 0,00 & 0,00 & 0,00 & 30,92 & 30,92 & & & $31 \%$ \\
\hline 3 & Hidroviário & Batagassu - Pederneiras & 74,46 & 4.000 & 605 & 0,00 & 0,00 & 3,00 & 22,53 & 25,53 & 98,44 & $54 \%$ & $26 \%$ \\
\hline & Ferroviário & Pederneiras - Santos & 403,98 & 5.200 & 502 & 0,00 & 0,00 & 3,00 & 39,00 & 42,00 & & & $43 \%$ \\
\hline & Rodoviário & Campo Grande - Três Lagoas & 2,37 & 40 & 350 & 0,00 & 0,00 & 0,00 & 29,01 & 29,01 & & & $34 \%$ \\
\hline 3 & Hidroviário & Três Lagoas - Pederneiras & 74,46 & 4.000 & 281 & 0,00 & 0,00 & 3,00 & 10,46 & 13,46 & 84,47 & $32 \%$ & $16 \%$ \\
\hline & Ferroviário & Pederneiras - Santos & 403,98 & 5.200 & 502 & 0,00 & 0,00 & 3,00 & 39,00 & 42,00 & & & $50 \%$ \\
\hline 1 & Rodoviário & Campo Grande - Paranaguá & 2,37 & 40 & 1.160 & 0,00 & 385,00 & 0,00 & 105,77 & 105,77 & 105,77 & $65 \%$ & $100 \%$ \\
\hline & Rodoviário & Campo Grande - Cascavel & 2,37 & 40 & 683 & 0,00 & 0,00 & 0,00 & 56,61 & 56,61 & & & $55 \%$ \\
\hline 2 & Ferroviário & Cascavel - Paranaguá & 122,52 & 2.100 & 737 & 0,00 & 0,00 & 3,00 & 43,00 & 46,00 & 102,61 & $60 \%$ & $45 \%$ \\
\hline 7 & Ferroviário & Campo Grande - Corumbá & 86,58 & 1.250 & 462 & 13,99 & 0,00 & 3,00 & 32,00 & 48,99 & & & $60 \%$ \\
\hline$t$ & Hidroviário & Corumbá - Nova Palmira & 190,65 & 18.000 & 2.770 & 0,00 & 0,00 & 3,00 & 29,34 & 32,34 & 81,33 & $27 \%$ & $40 \%$ \\
\hline & Rodoviário & Campo Grande - Chapadão do Sul & 2,37 & 40 & 332 & 0,00 & 0,00 & 0,00 & 27,52 & 27,52 & & & $23 \%$ \\
\hline 2 & Ferroviário & Chapadão do Sul - Santos & 519,37 & 7.000 & 1.182 & 0,00 & 0,00 & 3,00 & 87,70 & 90,70 & 118,22 & $85 \%$ & $77 \%$ \\
\hline & Rodoviário & Campo Grande - São Simão & 2,37 & 40 & 564 & 0,00 & 0,00 & 0,00 & 46,75 & 46,75 & & & $38 \%$ \\
\hline 3 & Hidroviário & São Simão - Pederneiras & 74,46 & 3.000 & 640 & 0,00 & 0,00 & 3,00 & 31,77 & 34,77 & 123,52 & $93 \%$ & $28 \%$ \\
\hline & Ferroviário & Pederneiras - Santos & 403,98 & 5.200 & 502 & 0,00 & 0,00 & 3,00 & 39,00 & 42,00 & & & $34 \%$ \\
\hline & Rodoviário & Campo Grande - P. Epitácio & 2,37 & 40 & 410 & 0,00 & 0,00 & 0,00 & 33,98 & 33,98 & 8248 & $29 \%$ & $41 \%$ \\
\hline 2 & Ferroviário & P. Epitácio - Santos & 175,00 & 2.500 & 650 & 0,00 & 0,00 & 3,00 & 45,50 & 48,50 & 82,48 & $29 \%$ & $59 \%$ \\
\hline & Rodoviário & Campo Grande - Maringá & 2,37 & 40 & 636 & 0,00 & 49,98 & 0,00 & 53,96 & 53,96 & & & $56 \%$ \\
\hline 2 & Ferroviário & Maringá - Paranaguá & 128,44 & 2.100 & 654 & 0,00 & 0,00 & 3,00 & 40,00 & 43,00 & 96,96 & $52 \%$ & $44 \%$ \\
\hline 4 & Ferroviário & Campo Grande - Paranaguá & 122,52 & 2.100 & 1.270 & 8,28 & 0,00 & 3,00 & 74,10 & 85,37 & 85,37 & $34 \%$ & $100 \%$ \\
\hline
\end{tabular}




\section{APÊNDICE $F$ - Custos para o Pólo de Dourados com bitrem de 7 eixos}

\section{CUSTOS DE TRANSPORTE POR ITINERÁRIOS - 0\% RETORNO}

TRANSPORTE DE SOJA

REGIÃO SUL - POLO DOURADOS

\begin{tabular}{|c|c|c|c|c|c|c|c|c|c|c|c|c|c|}
\hline & \multirow{2}{*}{\multicolumn{3}{|c|}{ Tarifas (R\$ por Tonelada) }} & \\
\hline & & & & \multirow{2}{*}{$\begin{array}{l}\text { Custo Total } \\
\text { por tonelada }\end{array}$} & \multirow[b]{2}{*}{$\%$} & \multirow{2}{*}{$\begin{array}{l}\text { Participação } \\
\text { nos custos }\end{array}$} \\
\hline Cenários & Modal (is) & $\operatorname{Trecho}(\mathrm{s})$ & Frete/Km & Peso (ton) & Km & Ponta Rd & Pedágio & Transbordo & Frete & Total & & & \\
\hline 1 & Rodoviário & Dourados - Santos & 2,37 & 40 & 1.145 & 0,00 & 690,20 & 0,00 & 152,83 & 152,83 & 152,83 & $107 \%$ & $100 \%$ \\
\hline 4 & Ferroviário & Dourados - Santos & 89,78 & 1.300 & 1.482 & $\begin{array}{ll}13,16 \\
\end{array}$ & 0,00 & 3,00 & 102,35 & 118,51 & 118,51 & $60 \%$ & $100 \%$ \\
\hline \multirow{2}{*}{6} & Rodoviário & Dourados - Pto Murtinho & 2,37 & 40 & 400 & 0,00 & 0,00 & 0,00 & 47,36 & 47,36 & \multirow[b]{2}{*}{74,00} & \multirow[b]{2}{*}{$0 \%$} & $64 \%$ \\
\hline & Hidroviário & Pto Murtinho - Nova Palmira & 190,65 & 18.000 & 2.232 & 0,00 & 0,00 & 3,00 & 23,64 & 26,64 & & & $36 \%$ \\
\hline \multirow{3}{*}{3} & Rodoviário & Dourados - Bataguassu & 2,37 & 40 & 330 & 0,00 & 0,00 & 0,00 & 39,07 & 39,07 & \multirow{3}{*}{106,60} & \multirow{3}{*}{$44 \%$} & $37 \%$ \\
\hline & \begin{tabular}{|l|} 
Hidroviário \\
\end{tabular} & Batagassu - Pederneiras & 74,46 & 4.000 & 605 & 0,00 & 0,00 & 3,00 & 22,53 & 25,53 & & & $24 \%$ \\
\hline & Ferroviário & Pederneiras - Santos & 403,98 & 5.200 & 502 & 0,00 & 0,00 & 3,00 & 39,00 & 42,00 & & & $39 \%$ \\
\hline 1 & Rodoviário & Dourados - Paranaguá & 2,37 & 40 & 940 & 0,00 & 180,60 & 0,00 & 115,82 & 115,82 & 115,82 & $57 \%$ & $100 \%$ \\
\hline \multirow{2}{*}{2} & Rodoviário & Dourados - Cascavel & 2,37 & 40 & 430 & 0,00 & 0,00 & 0,00 & 50,91 & 50,91 & \multirow{2}{*}{96,91} & \multirow[b]{2}{*}{$31 \%$} & $53 \%$ \\
\hline & Ferroviário & Cascavel - Paranaguá & 122,52 & 2.100 & 737 & 0,00 & 0,00 & 3,00 & 43,00 & 46,00 & & & $47 \%$ \\
\hline \multirow[b]{2}{*}{6} & Rodoviário & Dourados - Corumbá & 2,37 & 40 & 626 & 0,00 & 40,00 & $\overline{0,00}$ & 75,12 & 75,12 & \multirow{2}{*}{107,46} & \multirow{2}{*}{$45 \%$} & $70 \%$ \\
\hline & Hidroviário & Corumbá - Nova Palmira & 190,65 & 18.000 & 2.770 & 0,00 & 0,00 & 3,00 & 29,34 & 32,34 & & & $30 \%$ \\
\hline \multirow{2}{*}{2} & Rodoviário & Dourados - Chapadão do Sul & 2,37 & 40 & 552 & 0,00 & 0,00 & 0,00 & 65,36 & 65,36 & \multirow{2}{*}{156,06} & \multirow{2}{*}{$111 \%$} & $42 \%$ \\
\hline & Ferroviário & Chapadão do Sul - Santos & 519,37 & 7.000 & 1.182 & 0,00 & 0,00 & 3,00 & 87,70 & 90,70 & & & $58 \%$ \\
\hline \multirow{2}{*}{2} & Rodoviário & Dourados - P. Epitácio & 2,37 & 40 & 379 & 0,00 & 0,00 & 0,00 & 44,88 & 44,88 & \multirow{2}{*}{93,38} & \multirow{2}{*}{$26 \%$} & $48 \%$ \\
\hline & Ferroviário & P. Epitácio - Santos & 175,00 & 2.500 & 650 & 0,00 & 0,00 & 3,00 & 45,50 & 48,50 & & & $52 \%$ \\
\hline \multirow[b]{2}{*}{2} & Rodoviário & Dourados - Maringá & 2,37 & 40 & 500 & 0,00 & 71,40 & 0,00 & 60,99 & 60,99 & \multirow{2}{*}{103,99} & \multirow{2}{*}{$41 \%$} & $59 \%$ \\
\hline & Ferroviário & Maringá - Paranaguá & 128,44 & 2.100 & 654 & 0,00 & 0,00 & 3,00 & 40,00 & 43,00 & & & $41 \%$ \\
\hline 4 & Ferroviário & Dourados - Paranaguá & 122,52 & 2.100 & 1.087 & 13,16 & 0,00 & 3,00 & 63,42 & 79,58 & 79,58 & $8 \%$ & $100 \%$ \\
\hline
\end{tabular}


CUSTOS DE TRANSPORTE POR ITINERÁRIOS - 40\% RETORNO

\section{TRANSPORTE DE SOJA}

REGIÃO SUL - POLO DOURADOS

\begin{tabular}{|c|c|c|c|c|c|c|c|c|c|c|c|c|c|}
\hline & \multirow{2}{*}{\multicolumn{3}{|c|}{ Tarifas (R\$ por Tonelada) }} & \multirow[b]{2}{*}{$\begin{array}{c}\text { Custo Total } \\
\text { por tonelada }\end{array}$} & \multirow[b]{2}{*}{ 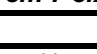 } & \multirow[b]{2}{*}{$\begin{array}{l}\text { Participação } \\
\text { nos custos }\end{array}$} \\
\hline & & & & & & & & & & & & & \\
\hline 1 & Rodoviário & Dourados - Santos & 2,37 & 40 & 1.126 & 0,00 & 568,40 & 0,00 & 120,87 & 120,87 & 120,87 & $87 \%$ & $100 \%$ \\
\hline 4 & Ferroviário & Dourados - Santos & 89,78 & 1.300 & 1.482 & 13,16 & 0,00 & 3,00 & 102,35 & 118,51 & 118,51 & $84 \%$ & $100 \%$ \\
\hline \multirow{2}{*}{6} & Rodoviário & Dourados - Pto Murtinho & 2,37 & 40 & 400 & 0,00 & 0,00 & 0,00 & 37,89 & 37,89 & \multirow[b]{2}{*}{64,53} & \multirow[b]{2}{*}{$0 \%$} & $59 \%$ \\
\hline & Hidroviário & Pto Murtinho - Nova Palmira & 190,65 & 18.000 & 2.232 & 0,00 & 0,00 & 3,00 & 23,64 & 26,64 & & & $41 \%$ \\
\hline \multirow{3}{*}{3} & Rodoviário & Dourados - Bataguassu & 2,37 & 40 & 330 & 0,00 & 0,00 & 0,00 & 31,26 & 31,26 & \multirow{3}{*}{98,78} & \multirow{3}{*}{$53 \%$} & $32 \%$ \\
\hline & Hidroviário & Batagassu - Pederneiras & 74,46 & 4.000 & 605 & 0,00 & 0,00 & 3,00 & 22,53 & 25,53 & & & $26 \%$ \\
\hline & Ferroviário & Pederneiras - Santos & 403,98 & 5.200 & 502 & 0,00 & 0,00 & 3,00 & 39,00 & 42,00 & & & $43 \%$ \\
\hline 1 & Rodoviário & Dourados - Paranaguá & 2,37 & 40 & 940 & 0,00 & 144,48 & 0,00 & 92,65 & 92,65 & 92,65 & $44 \%$ & $100 \%$ \\
\hline \multirow[b]{2}{*}{2} & Rodoviário & Dourados - Cascavel & 2,37 & 40 & 430 & 0,00 & 0,00 & 0,00 & 40,73 & 40,73 & \multirow{2}{*}{86,73} & \multirow{2}{*}{$34 \%$} & $47 \%$ \\
\hline & Ferroviário & Cascavel - Paranaguá & 122,52 & 2.100 & 737 & 0,00 & 0,00 & 3,00 & 43,00 & 46,00 & & & $53 \%$ \\
\hline \multirow{2}{*}{6} & Rodoviário & Dourados - Corumbá & 2,37 & 40 & 626 & 0,00 & 32,00 & 0,00 & 60,10 & 60,10 & \multirow{2}{*}{92,44} & \multirow{2}{*}{$43 \%$} & $65 \%$ \\
\hline & Hidroviário & Corumbá - Nova Palmira & 190,65 & 18.000 & 2.770 & 0,00 & 0,00 & 3,00 & 29,34 & 32,34 & & & $35 \%$ \\
\hline \multirow{2}{*}{2} & Rodoviário & Dourados - Chapadão do Sul & 2,37 & 40 & 552 & 0,00 & 0,00 & 0,00 & 52,29 & 52,29 & \multirow{2}{*}{142,99} & \multirow{2}{*}{$122 \%$} & $37 \%$ \\
\hline & Ferroviário & Chapadão do Sul - Santos & 519,37 & 7.000 & 1.182 & 0,00 & 0,00 & 3,00 & 87,70 & 90,70 & & & $63 \%$ \\
\hline \multirow[b]{2}{*}{2} & Rodoviário & Dourados - P. Epitácio & 2,37 & 40 & 379 & 0,00 & 0,00 & 0,00 & 35,90 & 35,90 & \multirow[b]{2}{*}{84,40} & \multirow{2}{*}{$31 \%$} & $43 \%$ \\
\hline & Ferroviário & P. Epitácio - Santos & 175,00 & 2.500 & 650 & 0,00 & 0,00 & 3,00 & 45,50 & 48,50 & & & $57 \%$ \\
\hline \multirow[b]{2}{*}{2} & Rodoviário & Dourados - Maringá & 2,37 & 40 & 500 & 0,00 & 57,12 & 0,00 & 48,79 & 48,79 & \multirow{2}{*}{91,79} & \multirow[b]{2}{*}{$42 \%$} & $53 \%$ \\
\hline & Ferroviário & Maringá - Paranaguá & 128,44 & 2.100 & 654 & 0,00 & 0,00 & 3,00 & 40,00 & 43,00 & & & $47 \%$ \\
\hline 4 & Ferroviário & Dourados - Paranaguá & 122,52 & 2.100 & 1.087 & 13,16 & 0,00 & 3,00 & 63,42 & 79,58 & 79,58 & $23 \%$ & $100 \%$ \\
\hline
\end{tabular}


CUSTOS DE TRANSPORTE POR ITINERÁRIOS - 60\% RETORNO

TRANSPORTE DE SOJA

REGIÃO SUL - POLO DOURADOS

\begin{tabular}{|c|c|c|c|c|c|c|c|c|c|c|c|c|c|}
\hline \multicolumn{8}{|c|}{ REGIAO SUL - POLO DOURADOS } & \multirow{2}{*}{\multicolumn{3}{|c|}{ Tarifas (R\$ por Tonelada) }} & \multicolumn{3}{|c|}{ Bitrem 7 eixos } \\
\hline & & & & & & & & & & & Custo Total & & Participação \\
\hline Cenários & Modal (is) & Trecho(s) & Frete/Km & Peso (ton) & Km & Ponta Rd & Pedágio & Transbordo & Frete & Total & por tonelada & $\%$ & \\
\hline 1 & Rodoviário & Dourados - Santos & 2,37 & 40 & 1.145 & 0,00 & 439,98 & 0,00 & 105,90 & 105,90 & 105,90 & $77 \%$ & $100 \%$ \\
\hline 4 & Ferroviário & Dourados - Santos & 89,78 & 1.300 & 1.482 & 13,16 & 0,00 & 3,00 & 102,35 & 118,51 & 118,51 & $98 \%$ & $100 \%$ \\
\hline & Rodoviário & Dourados - Pto Murtinho & 2,37 & 40 & 400 & 0,00 & 0,00 & 0,00 & 33,15 & 33,15 & & & $55 \%$ \\
\hline 6 & Hidroviário & Pto Murtinho - Nova Palmira & 190,65 & 18.000 & 2.232 & 0,00 & 0,00 & 3,00 & 23,64 & 26,64 & 59,19 & $0 \%$ & $45 \%$ \\
\hline & Rodoviário & Dourados - Bataguassu & 2,37 & 40 & 330 & 0,00 & 0,00 & 0,00 & 27,35 & 27,35 & & & $29 \%$ \\
\hline 3 & Hidroviário & Batagassu - Pederneiras & 74,46 & 4.000 & 605 & 0,00 & 0,00 & 3,00 & 22,53 & 25,53 & 94,88 & $59 \%$ & $27 \%$ \\
\hline & Ferroviário & Pederneiras - Santos & 403,98 & 5.200 & 502 & 0,00 & 0,00 & 3,00 & 39,00 & 42,00 & & & $44 \%$ \\
\hline 1 & Rodoviário & Dourados - Paranaguá & 2,37 & 40 & 940 & 0,00 & 126,42 & 0,00 & 81,07 & 81,07 & 81,07 & $36 \%$ & $100 \%$ \\
\hline & Rodoviário & Dourados - Cascavel & 2,37 & 40 & 430 & 0,00 & 0,00 & 0,00 & 35,64 & 35,64 & & & $44 \%$ \\
\hline 2 & Ferroviário & Cascavel - Paranaguá & 122,52 & 2.100 & 737 & 0,00 & 0,00 & 3,00 & 43,00 & 46,00 & 81,64 & $31 \%$ & $56 \%$ \\
\hline & Rodoviário & Dourados - Corumbá & 2,37 & 40 & 626 & 0,00 & 28,00 & 0,00 & 52,59 & 52,59 & & & $62 \%$ \\
\hline 0 & Hidroviário & Corumbá - Nova Palmira & 190,65 & 18.000 & 2.770 & 0,00 & 0,00 & 3,00 & 29,34 & 32,34 & 84,93 & $4 \angle \%$ & $38 \%$ \\
\hline & Rodoviário & Dourados - Chapadão do Sul & 2,37 & 40 & 552 & 0,00 & 0,00 & 0,00 & 45,75 & 45,75 & & & $34 \%$ \\
\hline 2 & Ferroviário & Chapadão do Sul - Santos & 519,37 & 7.000 & 1.182 & 0,00 & 0,00 & 3,00 & 87,70 & 90,70 & 136,45 & $128 \%$ & $66 \%$ \\
\hline 2 & Rodoviário & Dourados - P. Epitácio & 2,37 & 40 & 379 & 0,00 & 0,00 & 0,00 & 31,41 & 31,41 & 79,91 & $34 \%$ & $39 \%$ \\
\hline 2 & Ferroviário & P. Epitácio - Santos & 175,00 & 2.500 & 650 & 0,00 & 0,00 & 3,00 & 45,50 & 48,50 & 19,91 & $34 \%$ & $61 \%$ \\
\hline & Rodoviário & Dourados - Maringá & 2,37 & 40 & 500 & 0,00 & 49,98 & 0,00 & 42,69 & 42,69 & & & $50 \%$ \\
\hline 2 & Ferroviário & Maringá - Paranaguá & 128,44 & 2.100 & 654 & 0,00 & 0,00 & 3,00 & 40,00 & 43,00 & 85,69 & $43 \%$ & $50 \%$ \\
\hline 4 & Ferroviário & Dourados - Paranaguá & 122,52 & 2.100 & 1.087 & 13,16 & 0,00 & 3,00 & 63,42 & 79,58 & 79,58 & $33 \%$ & $100 \%$ \\
\hline
\end{tabular}


APÊNDICE G - Custos para o Pólo de Corumbá com o bitrem de 7 eixos

CUSTOS DE TRANSPORTE POR ITINERÁRIOS - 0\% RETORNO

TRANSPORTE DE MINÉRIOS DE FERRO E MANGANÊS

POLO CORUMBÁ

\begin{tabular}{|c|c|c|c|c|c|c|c|c|c|c|c|c|c|}
\hline & \multirow{2}{*}{\multicolumn{3}{|c|}{ Tarifas (R\$ por Tonelada) }} & \\
\hline & & & & & & & & & & & Custo Total & & JParticipação \\
\hline Cenários & Modal (is) & Trecho(s) & Frete/Km & Peso (ton) & $\overline{K m}$ & Ponta Rd & Pedágio & Transbordo & Frete & Total & por tonelada & $\%$ & nos custos \\
\hline 1 & Rodoviário & Corumbá - Santos & 2,37 & 40 & 1.572 & 0,00 & 681,20 & 0,00 & 203,16 & 203,16 & 203,16 & $466 \%$ & $100 \%$ \\
\hline 4 & Ferroviário & Corumbá - Santos & 66,46 & 1.250 & 1.768 & 3,55 & 0,00 & 3,00 & 94,00 & 100,55 & 100,55 & $180 \%$ & $100 \%$ \\
\hline 8 & Hidroviário & Corumbá - Nova Palmira & 190,65 & 18.000 & 2.770 & 3,55 & 0,00 & 3,00 & 29,34 & 35,89 & 35,89 & $0 \%$ & $100 \%$ \\
\hline 1 & Rodoviário & Corumbá - Paranaguá & 2,37 & 40 & 1.517 & 0,00 & 465,60 & 0,00 & 191,26 & 191,26 & 191,26 & $433 \%$ & $100 \%$ \\
\hline 2 & Rodoviário & Corumbá - Cascavel & 2,37 & 40 & 1041 & 0,00 & 40,00 & 0,00 & 124,26 & 124,26 & & & $73 \%$ \\
\hline & Ferroviário & Cascavel - Paranaguá & 122,52 & 2.100 & 737 & 0,00 & 0,00 & 3,00 & 43,00 & 46,00 & 170,26 & $374 \%$ & $27 \%$ \\
\hline 4 & Ferroviário & Corumbá - Paranaguá & 122,52 & 2.100 & 1.680 & 3,55 & 0,00 & 3,00 & 98,02 & 104,57 & 104,57 & $191 \%$ & $100 \%$ \\
\hline
\end{tabular}

\section{CUSTOS DE TRANSPORTE POR ITINERÁRIOS - 40\% RETORNO}

TRANSPORTE DE MINÉRIOS DE FERRO E MANGANÊS

POLO CORUMBÁ

\begin{tabular}{|c|c|c|c|c|c|c|c|c|c|c|c|c|c|}
\hline \multicolumn{8}{|c|}{ POLO CORUMBÁ } & & & & \multicolumn{3}{|c|}{ Bitrem 7 eixos } \\
\hline & & & & & & & & Tarifas $(R$ & por Ton & ada) & Custo Total & & Participação \\
\hline Cenários & Modal (is) & Trecho(s) & Frete/Km & Peso (ton) & Km & Ponta Rd & Pedágio & Transbordo & Frete & Total & por tonelada & $\%$ & nos custos \\
\hline 1 & Rodoviário & Corumbá - Santos & 2,37 & 40 & 1.572 & 0,00 & 544,96 & 0,00 & 162,53 & 162,53 & 162,53 & $353 \%$ & $100 \%$ \\
\hline 4 & Ferroviário & Corumbá - Santos & 66,46 & 1.250 & 1.768 & 3,55 & 0,00 & 3,00 & 94,00 & 100,55 & 100,55 & $180 \%$ & $100 \%$ \\
\hline 8 & Hidroviário & Corumbá - Nova Palmira & 190,65 & 18.000 & 2.770 & 3,55 & 0,00 & 3,00 & 29,34 & 35,89 & 35,89 & $0 \%$ & $100 \%$ \\
\hline 1 & Rodoviário & Corumbá - Paranaguá & 2,37 & 40 & 1.517 & 0,00 & 372,48 & 0,00 & 153,01 & 153,01 & 153,01 & $326 \%$ & $100 \%$ \\
\hline 2 & Rodoviário & Corumbá - Cascavel & 2,37 & 40 & 1041 & 0,00 & 32,00 & 0,00 & 99,41 & 99,41 & & $305 \%$ & $68 \%$ \\
\hline & Ferroviário & Cascavel - Paranaguá & 122,52 & 2.100 & 737 & 0,00 & 0,00 & 3,00 & 43,00 & 46,00 & 145,41 & & $32 \%$ \\
\hline 4 & Ferroviário & Corumbá - Paranaguá & 122,52 & 2.100 & 1.680 & 3,55 & 0,00 & 3,00 & 98,02 & 104,57 & 104,57 & $191 \%$ & $100 \%$ \\
\hline
\end{tabular}




\section{CUSTOS DE TRANSPORTE POR ITINERÁRIOS - 60\% RETORNO}

TRANSPORTE DE MINÉRIOS DE FERRO E MANGANÊS

\section{POLO CORUMBÁ}

\begin{tabular}{|c|c|c|c|c|c|c|c|c|c|c|c|c|c|}
\hline \multicolumn{8}{|c|}{ entor } & \multirow{2}{*}{\multicolumn{3}{|c|}{ Tarifas (R\$ por Tonelada) }} & \\
\hline & & & & & & & & & & & Custo Total & & Participação \\
\hline Cenários & Modal (is) & Trecho (s) & Frete/Km & Peso (ton) & $K m$ & Ponta Rd & Pedágio & Transbordo & Frete & Total & por tonelada & $\%$ & nos custos \\
\hline 1 & Rodoviário & Corumbá- Santos & 2,37 & 40 & 1.572 & 0,00 & 476,84 & 0,00 & 142,22 & 142,22 & 142,22 & $296 \%$ & $100 \%$ \\
\hline 4 & Ferroviário & Corumbá - Santos & 66,46 & 1.250 & 1.768 & 3,55 & 0,00 & 3,00 & 94,00 & 100,55 & 100,55 & $180 \%$ & $100 \%$ \\
\hline 8 & Hidroviário & Corumbá - Nova Palmira & 190,65 & 18.000 & 2.770 & 3,55 & 0,00 & 3,00 & 29,34 & 35,89 & 35,89 & $0 \%$ & $100 \%$ \\
\hline 1 & Rodoviário & Corumbá - Paranaguá & 2,37 & 40 & 1.517 & 0,00 & 325,92 & 0,00 & 133,88 & 133,88 & 133,88 & $273 \%$ & $100 \%$ \\
\hline 2 & Rodoviário & Corumbá - Cascavel & 2,37 & 40 & 1041 & 0,00 & 28,00 & 0,00 & 86,98 & 86,98 & 13298 & $271 \%$ & $65 \%$ \\
\hline 2 & Ferroviário & Cascavel - Paranaguá & 122,52 & 2.100 & 737 & 0,00 & 0,00 & 3,00 & 43,00 & 46,00 & 132,98 & $271 \%$ & $35 \%$ \\
\hline 4 & Ferroviário & Corumbá - Paranaguá & 122,52 & 2.100 & 1.680 & 3,55 & 0,00 & 3,00 & 98,02 & 104,57 & 104,57 & $191 \%$ & $100 \%$ \\
\hline
\end{tabular}




\section{APÊNDICE H - custos do bitrem de 9 eixos}

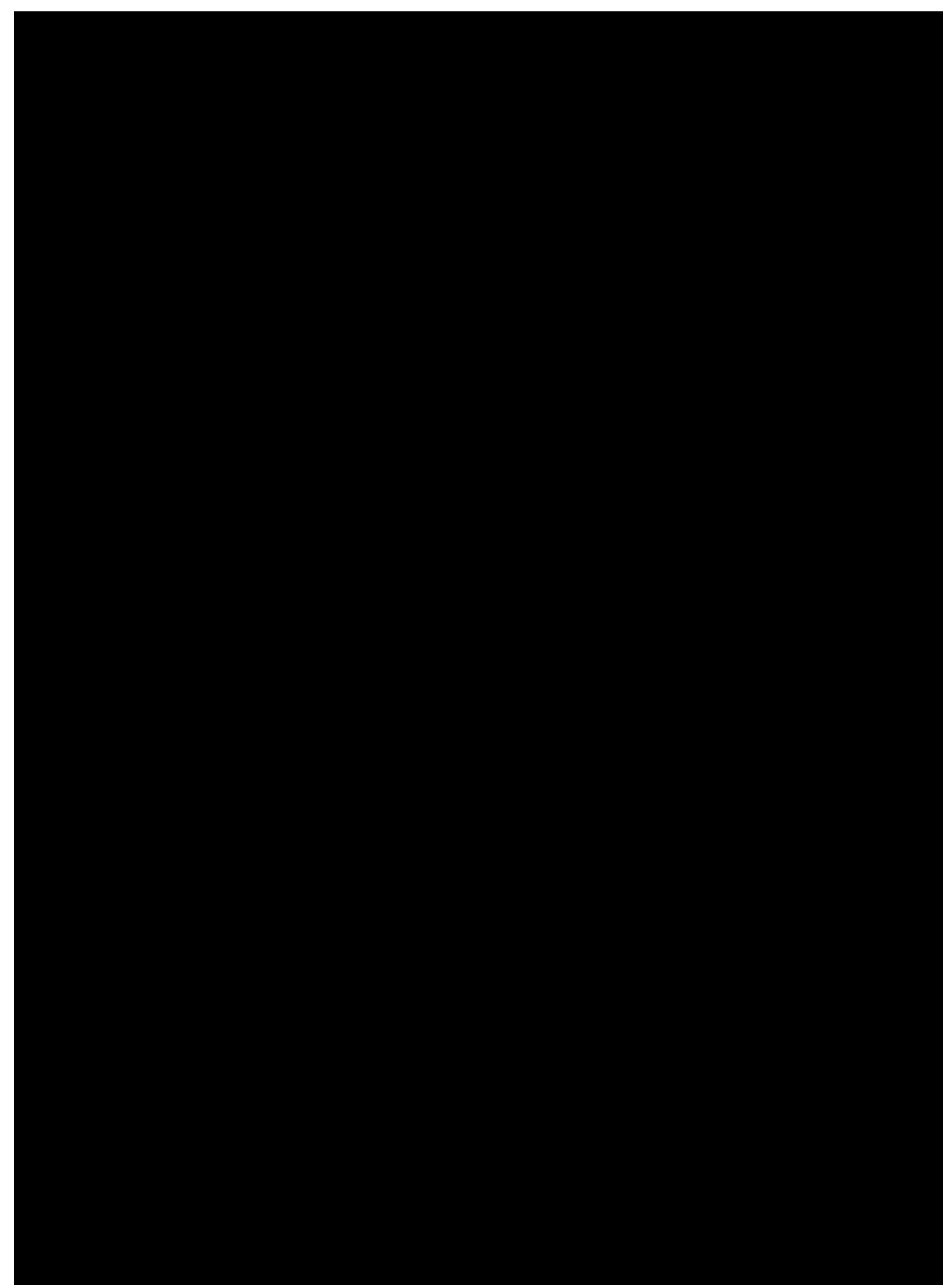


A - Custos Fixos Mensais : $(a+b+c+d+e+f+g+h+i+j)$

a - Remuneração de capital

$5.673,90$

b - Salário do motorista

$2.030,96$

c - Salário de oficina

660,06

d - Reposição do veículo

$2.001,78$

e - Reposição do semi-reboque

433,33

f - Licenciamento

451,77

g - Seguro do casco do veículo

$3.293,64$

$\mathrm{h}$ - Seguro do casco do equipamento

$1.468,11$

i - Seguro de responsabilidade civil facultativa

\section{B - Custos Variáveis: $(a+b+c+d+e)$}

1,59

a - Peças, acessórios e materiais de manutenção

b - Combustíveis

c - Lubrificantes

0,05

0,26

e - Pneus

C - Custo Total por Quilômetro

D - Custo por Tonelada Quilômetro

A - Custos Fixos Mensais: $(a+b+c+d+e+f+g+h+i+j)$

$16.125,22$

a - Remuneração de Capital [(11)+ (13)]/12

$5.673,90$

01 - Valor do veículo

02 - Rodoar

03 - Valor do semi-reboque

04 - Valor do $3^{\circ}$ eixo s/pneus

05 - Quantidade de pneus - semi-reboque

06 - Valor do pneu do semi-reboque

07 - Valor da câmara do semi-reboque

08 - Valor do protetor do semi-reboque

09 - Valor Total $(1+2+3+4+(5 \times(6+7+8)))$

10 - Taxa de remuneração do capital (a.a)

11 - Valor anual da remuneração do capital

12 - Taxa de remuneração de peças (a.a)

13 - Valor anual de remuneração de peças - $(9 \times 12)$
$357.039,06$

$1.000,00$

$130.000,00$

0,00

24,00

$1.355,00$

83,41

49,31

$523.744,34$

0,12

$62.849,32$

0,01

$5.237,44$ 


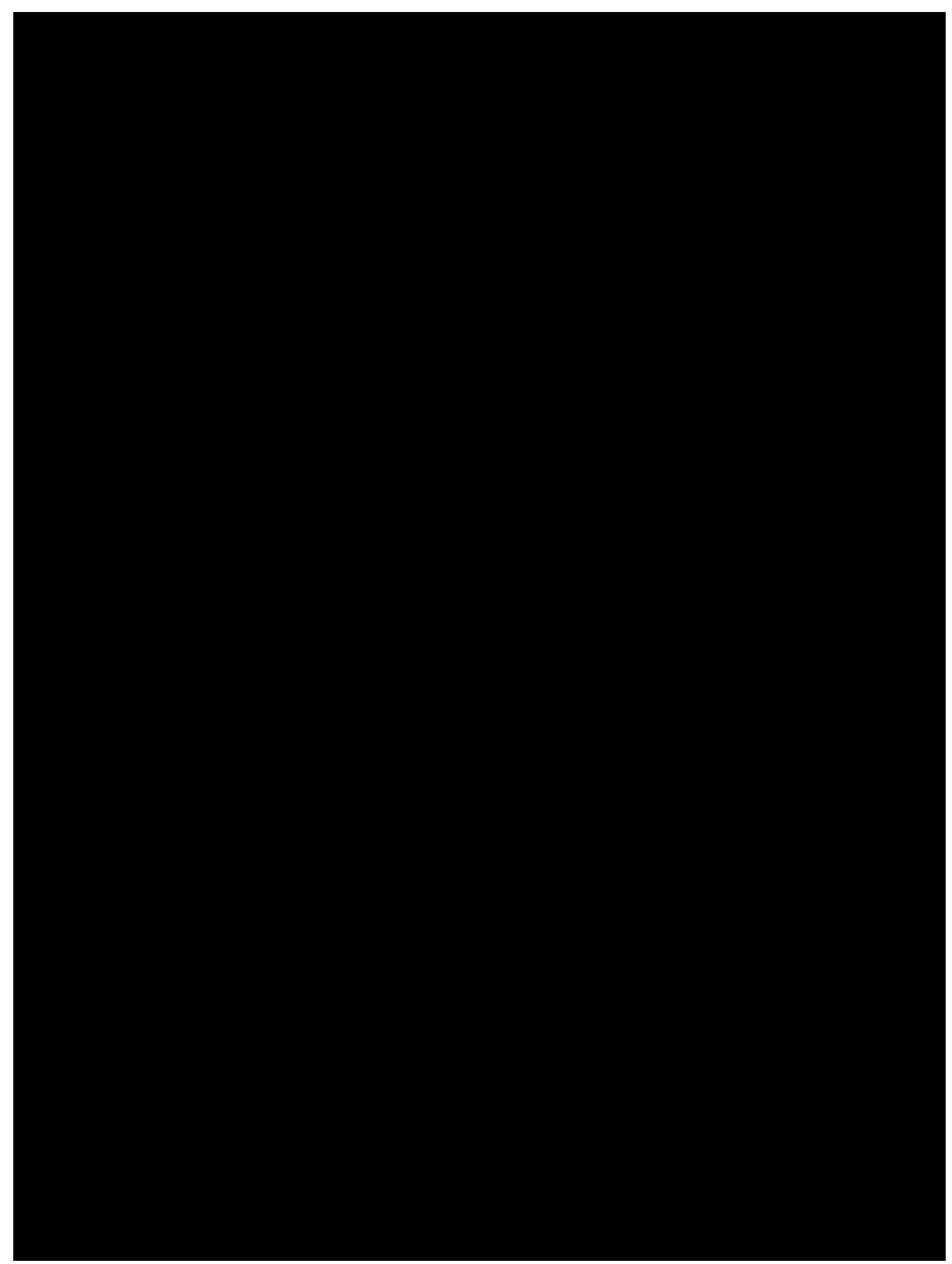




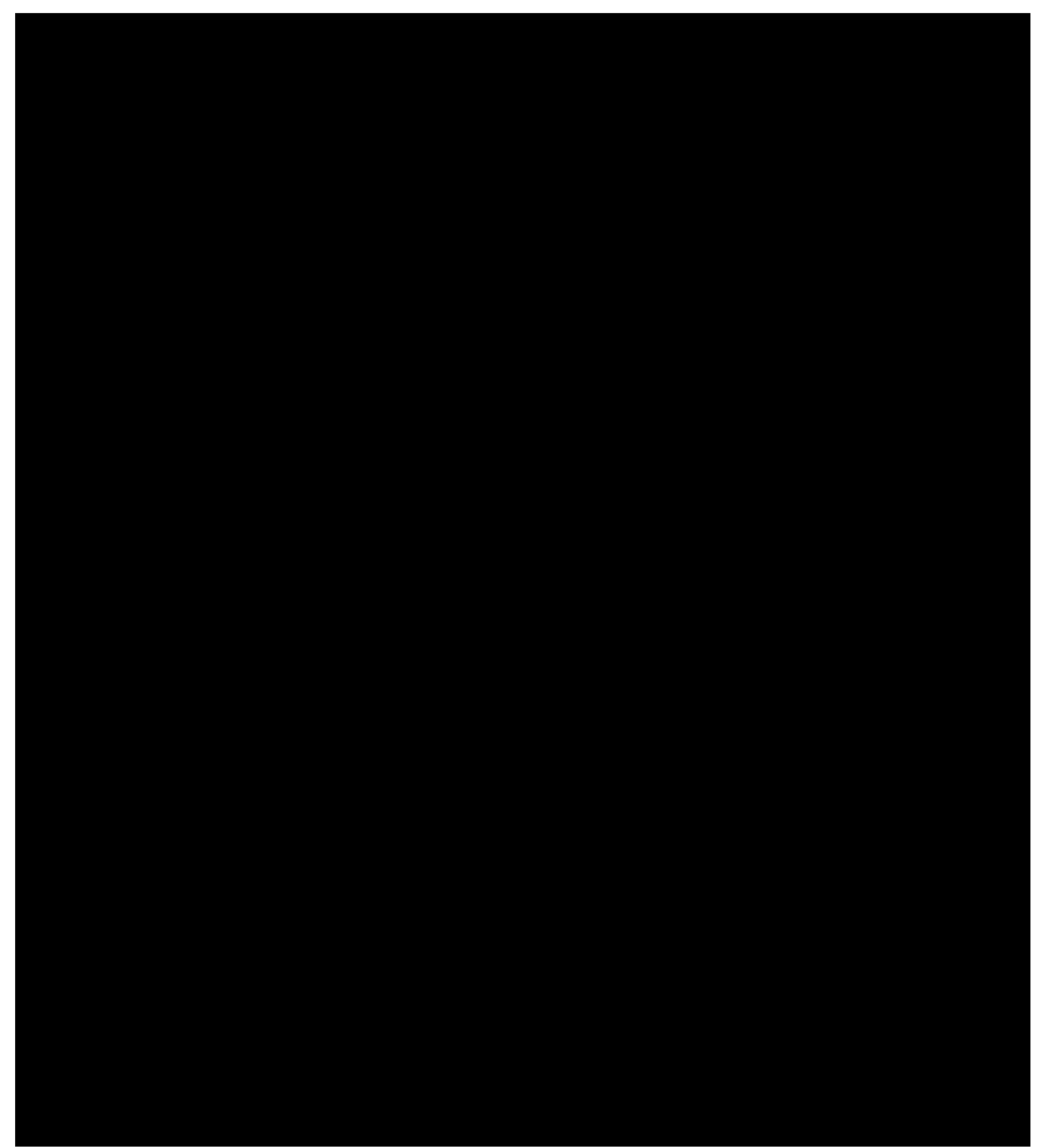




\section{APÊNDICE I - Custos para o Pólo de Chapadão do Sul com bitrem de 9 eixos}

\section{CUSTOS DE TRANSPORTE POR ITINERÁRIOS - 0\% RETORNO}

\section{TRANSPORTE DE SOJA}

\section{REGIÃO NORTE - POLO CHAPADÃO DO SUL}

\begin{tabular}{|l|l|l|}
\hline Cenários & Modal (is) & Trecho (s) \\
\hline
\end{tabular}

\begin{tabular}{|c|c|c|c|c|c|c|c|c|c|c|}
\hline & & & & & & & & Tarifas (RS & oor Tonela & \\
\hline enários & Modal (is) & Trecho (s) & Frete/Km & Peso (t) & $K m$ & Ponta Rd & Pedágio & Transbordo & Frete & Total \\
\hline 1 & Rodoviário & Chapadão do Sul - Santos & 2,66 & 52 & 1.000 & 0,00 & 1020,60 & 0,00 & 122,05 & 12 \\
\hline
\end{tabular}

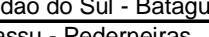

\begin{tabular}{lll}
\hline Hidroviarínio & Bederneiras - Santos \\
\hline Ferroviário & Ped
\end{tabular}

Rodoviário Chapadão do Sul - São Simão

Hidroviário $\quad$ São Simão - Pederneiras

Ferroviário Pederneiras - Santos

Ferroviário $\quad$ Chapadão do Sul - Santos

Rodoviário Chapadão do Sul - Três Lagoas

Hidroviário $\quad$ Três Lagoas - Pederneiras

\begin{tabular}{l|l}
\hline Ferroviário & Pederneiras - Santos \\
\hline
\end{tabular}

\begin{tabular}{l|l|l|}
\hline 1 & Rodoviário & Chapadão do Sul - Paranagu \\
\hline 2 & Rodoviário & Chapadão do Sul - Cascave \\
\cline { 2 - 3 } & Ferroviário & Cascavel - Paranaguá \\
\hline
\end{tabular}

Rodoviário $\quad$ Chapadão do Sul - Campo Grande

\begin{tabular}{l|l|l}
5 & Ferroviário & Campo Grande - Corumbá \\
\cline { 2 - 3 } & &
\end{tabular}

\begin{tabular}{ll} 
Eerroviário & Campo Grande - Corumbá \\
\hline Hidroviário & Corumbá - Nova Palmira \\
\hline Rodovia & Chapa
\end{tabular}

\begin{tabular}{l|l|l}
\hline \multirow{2}{*}{6} & Rodoviário & Chapadão do Sul - Corumbá \\
\cline { 2 - 3 } & Hidroviário & Corumbá - Nova Palmira \\
\hline
\end{tabular}

6 Rodoviário Chapadão do Sul - Porto Murtinho

\begin{tabular}{|l|l|}
\hline Rodoviário & Chapadão do Sul - Porto Murtin \\
\hline Hidroviário & Porto Murtinho - Nova Palmira \\
\hline
\end{tabular}

Rodoviário

\begin{tabular}{|l|l|}
\hline Ferroviário & P. Epitácio - Santos \\
\hline
\end{tabular}

Rodoviário Chapadão do Sul - Campo Grande

Chapadão do Sul - Campo Grá

\begin{tabular}{|c|c|c|c|c|c|c|c|}
\hline & & & & & & & \\
\hline Frete/Km & Peso (t) & $K m$ & Ponta Rd & Pedágio & Transbordo & Frete & Total \\
\hline 2,66 & 52 & 1.000 & 0,00 & 1020,60 & 0,00 & 122,05 & 122,05 \\
\hline 2,66 & 52 & 452 & 0,00 & 0,00 & 0,00 & 46,29 & 46,29 \\
\hline 74,46 & 4.000 & 605 & 0,00 & 0,00 & 3,00 & 22,53 & 25,53 \\
\hline 403,98 & 5.200 & 502 & 0,00 & 0,00 & 3,00 & 39,00 & 42,00 \\
\hline 2,66 & 52 & 321 & 0,00 & 0,00 & 0,00 & 32,88 & 32,88 \\
\hline 74,46 & 4.000 & 640 & 0,00 & 0,00 & 3,00 & 23,83 & 26,83 \\
\hline 403,98 & 5.200 & 502 & 0,00 & 0,00 & 3,00 & 39,00 & 42,00 \\
\hline 519,37 & 7.000 & 1.182 & 20,84 & 0,00 & 3,00 & 87,70 & 111,54 \\
\hline 2,66 & 52 & 317 & 0,00 & 0,00 & 0,00 & 32,47| & 32,47 \\
\hline 74,46 & 4.000 & 281 & 0,00 & 0,00 & 3,00 & \begin{tabular}{l|l|}
10,46 \\
\end{tabular} & 13,46 \\
\hline 403,98 & 5.200 & 502 & 0,00 & 0,00 & 3,00 & 39,00 & 42,00 \\
\hline 2,66 & 52 & 1.220 & 0,00 & 147,60 & 0,00 & 127,79 & 127,79 \\
\hline 2,66 & 52 & 988 & 0,00 & 0,00 & 0,00 & 101,19 & 101,19 \\
\hline 122,52 & 2.100 & 737 & 0,00 & 0,00 & 3,00 & 43,00 & 46,00 \\
\hline 2,66 & 52 & 369 & 0,00 & 0,00 & 0,00 & 37,79 & 37,79 \\
\hline 86,58 & 1.250 & 462 & 0,00 & 0,00 & 3,00 & 32,00 & 35,00 \\
\hline 190,65 & 18.000 & 2.770 & 0,00 & 0,00 & 3,00 & 29,34 & 32,34 \\
\hline 2,66 & 52 & 802 & 0,00 & 40,00 & 0,00 & 82,91 & 82,91 \\
\hline 190,65 & 18.000 & 2.770 & 0,00 & 0,00 & 3,00 & 29,34 & 32,34 \\
\hline 2,66 & 52 & 792 & 0,00 & 0,00 & 0,00 & 81,12 & 81,12 \\
\hline 190,65 & 18.000 & 2.232 & 0,00 & 0,00 & 3,00 & 23,64 & 26,64 \\
\hline 2,66 & 52 & 542 & 0,00 & 0,00 & 0,00 & 55,51 & 55,51 \\
\hline 175,00 & 2.500 & 650 & 0,00 & 0,00 & 3,00 & 45,50 & 48,50 \\
\hline 2,66 & 52 & 369 & 0,00 & 0,00 & 0,00 & 37,79 & 37,79 \\
\hline 122,52 & 2.100 & 1.270 & 0,00 & 0,00 & 3,00 & 74,10 & 77,10 \\
\hline
\end{tabular}

Bitrem 9 eixos

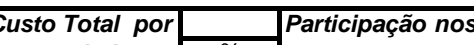

\begin{tabular}{c|c|c|} 
tonelada & $\%$ & custos \\
\cline { 2 - 3 } 122,05 & $3 \%$ &
\end{tabular}

\begin{tabular}{|c|c|c|}
\hline 122,05 & $39 \%$ & $100 \%$ \\
\hline \multirow{3}{*}{113,82} & \multirow{3}{*}{$29 \%$} & $41 \%$ \\
\hline & & $22 \%$ \\
\hline & & $37 \%$ \\
\hline \multirow{3}{*}{101,70} & \multirow{3}{*}{$16 \%$} & $32 \%$ \\
\hline & & $26 \%$ \\
\hline & & $41 \%$ \\
\hline 111,54 & $27 \%$ & $100 \%$ \\
\hline \multirow{3}{*}{87,93} & \multirow{3}{*}{$0 \%$} & $37 \%$ \\
\hline & & $15 \%$ \\
\hline & & $48 \%$ \\
\hline 127,79 & $45 \%$ & $100 \%$ \\
\hline 147,19 & $67 \%$ & $69 \%$ \\
\hline \multirow{3}{*}{105,13} & \multirow{3}{*}{$20 \%$} & $36 \%$ \\
\hline & & $33 \%$ \\
\hline & & $31 \%$ \\
\hline \multirow{2}{*}{115,25} & \multirow{2}{*}{$31 \%$} & $72 \%$ \\
\hline & & $28 \%$ \\
\hline 107,76 & $23 \%$ & $75 \%$ \\
\hline \multirow{2}{*}{104,01} & \multirow{2}{*}{$18 \%$} & $53 \%$ \\
\hline & & $47 \%$ \\
\hline \multirow{2}{*}{114,89} & \multirow{2}{*}{$31 \%$} & $33 \%$ \\
\hline & & $67 \%$ \\
\hline
\end{tabular}


CUSTOS DE TRANSPORTE POR ITINERÁRIOS - 40\% RETORNO

TRANSPORTE DE SOJA

REGIÃO NORTE - POLO CHAPADÃO DO SUL

\begin{tabular}{|c|c|c|c|c|c|c|c|c|c|c|c|c|c|}
\hline & \multirow{2}{*}{\multicolumn{3}{|c|}{ Tarifas (R\$ por Tonelada) }} & \multirow{3}{*}{\begin{tabular}{|c|} 
Custo \\
Total por \\
\end{tabular}} & \multirow[b]{2}{*}{ 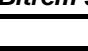 } & \multirow[b]{2}{*}{$\begin{array}{l}\text { Participação nos } \\
\text { custos }\end{array}$} \\
\hline Cenários & Modal (is) & Trecho (s) & Frete/Km & Peso (ton) & $K m$ & Ponta Rd & Pedágio & & & & & & \\
\hline 1 & Rodoviário & Chapadão do Sul - Santos & 2,66 & 52 & 1.000 & 0,00 & 849,86 & 0,00 & 98,28 & 98,28 & & $21 \%$ & $100 \%$ \\
\hline \multirow{3}{*}{3} & Rodoviário & Chapadão do Sul - Bataguassu & 2,66 & 52 & 452 & 0,00 & 0,00 & 0,00 & 37,03 & 37,03 & \multirow{3}{*}{104,56} & \multirow{3}{*}{$28 \%$} & $35 \%$ \\
\hline & Hidroviário & Batagassu - Pederneiras & 74,46 & 4.000 & 605 & 0,00 & 0,00 & 3,00 & 22,53 & 25,53 & & & $24 \%$ \\
\hline & Ferroviário & Pederneiras - Santos & 403,98 & 5.200 & 502 & 0,00 & 0,00 & 3,00 & 39,00 & 42,00 & & & $40 \%$ \\
\hline \multirow{3}{*}{3} & Rodoviário & Chapadão do Sul - São Simão & 2,66 & 52 & 321 & 0,00 & 0,00 & 0,00 & 26,30 & 26,30 & \multirow{3}{*}{95,13} & \multirow{3}{*}{$17 \%$} & $28 \%$ \\
\hline & Hidroviário & São Simão - Pederneiras & 74,46 & 4.000 & 640 & 0,00 & 0,00 & 3,00 & 23,83 & 26,83 & & & $28 \%$ \\
\hline & Ferroviário & Pederneiras - Santos & 403,98 & 5.200 & 502 & 0,00 & 0,00 & 3,00 & 39,00 & 42,00 & & & $44 \%$ \\
\hline 4 & Ferroviário & Chapadão do Sul - Santos & 519,37 & 7.000 & 1.182 & 20,84 & 0,00 & 3,00 & 87,70 & 111,54 & 111,54 & $37 \%$ & $100 \%$ \\
\hline \multirow{3}{*}{3} & Rodoviário & Chapadão do Sul - Três Lagoas & 2,66 & 52 & 317 & 0,00 & 0,00 & 0,00 & 25,97 & 25,97 & \multirow{3}{*}{81,44} & \multirow{3}{*}{$0 \%$} & $32 \%$ \\
\hline & Hidroviário & Três Lagoas - Pederneiras & 74,46 & 4.000 & 281 & 0,00 & 0,00 & 3,00 & 10,46 & 13,46 & & & $17 \%$ \\
\hline & Ferroviário & Pederneiras - Santos & 403,98 & 5.200 & 502 & 0,00 & 0,00 & 3,00 & 39,00 & 42,00 & & & $52 \%$ \\
\hline 1 & Rodoviário & Chapadão do Sul - Paranaguá & 2,66 & 52 & 1.220 & 0,00 & \begin{tabular}{|c|c|}
118,08 \\
\end{tabular} & 0,00 & 102,23 & 102,23 & 102,23 & $26 \%$ & $100 \%$ \\
\hline \multirow[b]{2}{*}{2} & Rodoviário & Chapadão do Sul - Cascavel & 2,66 & 52 & 988 & 0,00 & 0,00 & 0,00 & 80,95 & 80,95 & \multirow[b]{2}{*}{126,95} & \multirow[b]{2}{*}{$56 \%$} & $64 \%$ \\
\hline & Ferroviário & Cascavel - Paranaguá & 122,52 & 2.100 & 737 & 0,00 & 0,00 & 3,00 & 43,00 & 46,00 & & & $36 \%$ \\
\hline \multirow{3}{*}{5} & Rodoviário & Chapadão do Sul - Campo Grande & 2,66 & 52 & 369 & 0,00 & 0,00 & 0,00 & 30,23 & 30,23 & \multirow{3}{*}{97,57} & \multirow{3}{*}{$20 \%$} & $31 \%$ \\
\hline & Ferroviário & Campo Grande - Corumbá & 86,58 & 1.250 & 462 & 0,00 & 0,00 & 3,00 & 32,00 & 35,00 & & & $36 \%$ \\
\hline & Hidroviário & Corumbá - Nova Palmira & 190,65 & 18.000 & 2.770 & 0,00 & 0,00 & 3,00 & 29,34 & 32,34 & & & $33 \%$ \\
\hline \multirow{2}{*}{6} & Rodoviário & Chapadão do Sul - Corumbá & 2,66 & 52 & 788 & 0,00 & 32,00 & 0,00 & 65,18 & 65,18 & \multirow[b]{2}{*}{97,52} & \multirow{2}{*}{$20 \%$} & $67 \%$ \\
\hline & Hidroviário & Corumbá - Nova Palmira & 190,65 & 18.000 & 2.770 & 0,00 & 0,00 & 3,00 & 29,34 & 32,34 & & & $33 \%$ \\
\hline \multirow[b]{2}{*}{6} & Rodoviário & Chapadão do Sul - Porto Murtinho & 2,66 & 52 & 772 & 0,00 & 0,00 & 0,00 & 63,25 & 63,25 & \multirow[b]{2}{*}{89,90} & \multirow{2}{*}{$10 \%$} & $70 \%$ \\
\hline & Hidroviário & Porto Murtinho - Nova Palmira & 190,65 & 18.000 & 2.232 & 0,00 & 0,00 & 3,00 & 23,64 & 26,64 & & & $30 \%$ \\
\hline \multirow[b]{2}{*}{2} & Rodoviário & Chapadão do Sul - P. Epitácio & 2,66 & 52 & 542 & 0,00 & 0,00 & 0,00 & 44,41 & 44,41 & \multirow{2}{*}{92,91} & \multirow{2}{*}{$14 \%$} & $48 \%$ \\
\hline & Ferroviário & P. Epitácio - Santos & 175,00 & 2.500 & 650 & 0,00 & 0,00 & 3,00 & 45,50 & 48,50 & & & $52 \%$ \\
\hline$?$ & Rodoviário & Chapadão do Sul - Campo Grande & 2,66 & 52 & 369 & 0,00 & 0,00 & 0,00 & 30,23 & 30,23 & 10733 & $32 \%$ & $28 \%$ \\
\hline 2 & Ferroviário & Campo Grande - Paranaguá & 122,52 & 2.100 & 1.270 & 0,00 & 0,00 & 3,00 & 74,10 & 77,10 & 107,33 & $32 \%$ & $72 \%$ \\
\hline
\end{tabular}




\section{CUSTOS DE TRANSPORTE POR ITINERÁRIOS - 60\% RETORNO}

\section{TRANSPORTE DE SOJA}

REGIÃO NORTE - POLO CHAPADÃO DO SUL

\begin{tabular}{|c|c|c|c|c|c|c|c|c|c|c|c|c|c|}
\hline \multicolumn{8}{|c|}{ REGIÃO NORTE - POLO CHAPADÃO DO SUL } & & & & \multicolumn{3}{|c|}{ Bitrem 9 eixos } \\
\hline & & & & & & & & Tarifas $(R \$)$ & or Tonel & & Custo Total por & & Participação \\
\hline Cenários & Modal (is) & Trecho(s) & Frete/Km & Peso(ton) & $\mathrm{Km}$ & Ponta Rd & Pedágio & Transbordo & Frete & Total & tonelada & $\%$ & nos custos \\
\hline 1 & Rodoviário & Chapadão do Sul - Santos & 2,66 & 52 & 1.000 & 0,00 & 694,26 & 0,00 & 85,04 & 85,04 & 85,04 & $9 \%$ & $100 \%$ \\
\hline & Rodoviário & Chapadão do Sul - Bataguassu & 2,66 & 52 & 452 & 0,00 & 0,00 & 0,00 & 32,41 & 32,41 & & & $32 \%$ \\
\hline 3 & Hidroviário & Batagassu - Pederneiras & 74,46 & 4.000 & 605 & 0,00 & 0,00 & 3,00 & 22,53 & 25,53 & 99,93 & $28 \%$ & $26 \%$ \\
\hline & Ferroviário & \begin{tabular}{|l|} 
Pederneiras - Santos \\
\end{tabular} & 403,98 & 5.200 & 502 & 0,00 & 0,00 & 3,00 & 39,00 & 42,00 & & & $42 \%$ \\
\hline & Rodoviário & Chapadâo do Sul - São Simão & 2,66 & 52 & 321 & 0,00 & 0,00 & 0,00 & 23,01 & 23,01 & & & $25 \%$ \\
\hline 3 & Hidroviário & São Simão - Pederneiras & 74,46 & 4.000 & 640 & 0,00 & 0,00 & 3,00 & 23,83 & 26,83 & 91,84 & $17 \%$ & $29 \%$ \\
\hline & Ferroviário & Pederneiras - Santos & 403,98 & 5.200 & 502 & 0,00 & 0,00 & 3,00 & 39,00 & 42,00 & & & $46 \%$ \\
\hline 4 & Ferroviário & Chapadão do Sul - Santos & 519,37 & 7.000 & 1.182 & 20,84 & 0,00 & 3,00 & 87,70 & 111,54 & 111,54 & $43 \%$ & $100 \%$ \\
\hline & Rodoviário & Chapadão do Sul - Três Lagoas & 2,66 & 52 & 317 & 0,00 & 0,00 & 0,00 & 22,73 & 22,73 & & & $29 \%$ \\
\hline 3 & Hidroviário & Três Lagoas - Pederneiras & 74,46 & 4.000 & 281 & 0,00 & 0,00 & 3,00 & 10,46 & 13,46 & 78,19 & $0 \%$ & $17 \%$ \\
\hline & Ferroviário & Pederneiras - Santos & 403,98 & 5.200 & 502 & 0,00 & 0,00 & 3,00 & 39,00 & 42,00 & & & $54 \%$ \\
\hline 1 & Rodoviário & Chapadão do Sul - Paranaguá & 2,66 & 52 & 1.220 & 0,00 & 103,32 & 0,00 & 89,45 & 89,45 & 89,45 & $14 \%$ & $100 \%$ \\
\hline & Rodoviário & Chapadão do Sul - Cascavel & 2,66 & 52 & 988 & 0,00 & 0,00 & 0,00 & 70,83 & 70,83 & & & $61 \%$ \\
\hline 2 & Ferroviário & Cascavel - Paranaguá & 122,52 & 2.100 & 737 & 0,00 & 0,00 & 3,00 & 43,00 & 46,00 & 116,83 & $49 \%$ & $39 \%$ \\
\hline & Rodoviário & Chapadão do Sul - Campo Grande & 2,66 & 52 & 369 & 0,00 & 0,00 & 0,00 & 26,45 & 26,45 & & & $28 \%$ \\
\hline 5 & Ferroviário & Campo Grande - Corumbá & 86,58 & 1.250 & 462 & 0,00 & 0,00 & 3,00 & 32,00 & 35,00 & 93,79 & $20 \%$ & $37 \%$ \\
\hline & Hidroviário & Corumbá - Nova Palmira & 190,65 & 18.000 & 2.770 & 0,00 & 0,00 & 3,00 & 29,34 & 32,34 & & & $34 \%$ \\
\hline & Rodoviário & Chapadão do Sul - Corumbá & 2,66 & 52 & 802 & $\overline{0,00}$ & 28,00 & 0,00 & 58,04 & 58,04 & (0 20 & $160 \%$ & $64 \%$ \\
\hline 6 & Hidroviário & Corumbá - Nova Palmira & 190,65 & 18.000 & 2.770 & 0,00 & 0,00 & 3,00 & 29,34 & 32,34 & 90,38 & $16 \%$ & $36 \%$ \\
\hline & Rodoviário & Chapadão do Sul - Porto Murtinho & 2,66 & 52 & 792 & 0,00 & 0,00 & 0,00 & 56,78 & 56,78 & & & $68 \%$ \\
\hline 6 & Hidroviário & Porto Murtinho - Nova Palmira & 190,65 & 18.000 & 2.232 & 0,00 & 0,00 & 3,00 & 23,64 & 26,64 & 83,42 & $7 \%$ & $32 \%$ \\
\hline & Rodoviário & Chapadão do Sul - P. Epitácio & 2,66 & 52 & 542 & 0,00 & 0,00 & 0,00 & 38,86 & 38,86 & & & $44 \%$ \\
\hline 2 & Ferroviário & P. Epitácio - Santos & 175,00 & 2.500 & 650 & 0,00 & 0,00 & 3,00 & 45,50 & 48,50 & 87,36 & $12 \%$ & $56 \%$ \\
\hline 2 & Rodoviário & Chapadão do Sul - Campo Grande & 2,66 & 52 & 369 & 0,00 & 0,00 & 0,00 & 26,45 & 26,45 & 10355 & $32 \%$ & $26 \%$ \\
\hline 2 & Ferroviário & Campo Grande - Paranaguá & 122,52 & 2.100 & 1.270 & 0,00 & 0,00 & 3,00 & 74,10 & 77,10 & 103,55 & $32 \%$ & $74 \%$ \\
\hline
\end{tabular}




\section{APÊNDICE $J$ - Custos para o Pólo de Campo Grande com bitrem de 9 eixos}

\section{CUSTOS DE TRANSPORTE POR ITINERÁRIOS - O\% RETORNO}

\section{TRANSPORTE DE SOJA}

REGIÃO CENTRAL - POLO CAMPO GRANDE

\begin{tabular}{|c|c|c|c|c|c|c|c|c|c|c|c|c|c|}
\hline \multicolumn{8}{|c|}{$R A$} & \multirow{2}{*}{\multicolumn{3}{|c|}{ Tarifas (R\$ por Tonelada) }} & \multicolumn{3}{|r|}{ xos } \\
\hline Cenários & Modal (is) & Trecho(s) & Frete/Km & Peso (ton) & $K m$ & Ponta Rd & Pedágio & & & & $\begin{array}{l}\text { Custo Total por } \\
\text { tonelada }\end{array}$ & $\%$ & $\begin{array}{l}\text { Participação nos } \\
\text { custos }\end{array}$ \\
\hline 1 & Rodoviário & Campo Grande - Santos & 2,66 & 52 & 1.155 & 0,00 & 855,90 & 0,00 & 134,75 & 134,75 & 134,75 & $85 \%$ & $100 \%$ \\
\hline 4 & Ferroviário & Campo Grande - Santos & 172,66 & 2.500 & 1.306 & 13,99 & 0,00 & 3,00 & 90,21 & 107,20 & 107,20 & $47 \%$ & $100 \%$ \\
\hline 6 & Rodoviário & Campo Grande - Pto Murtinho & 2,66 & 52 & 450 & 0,00 & 0,00 & 0,00 & 46,09 & 46,09 & 7273 & $\Omega$ & $63 \%$ \\
\hline 6 & Hidroviário & Pto Murtinho - Nova Palmira & 190,65 & 18.000 & 2.232 & 0,00 & 0,00 & 3,00 & 23,64 & 26,64 & $12, \sqrt{3}$ & $0 \%$ & $37 \%$ \\
\hline & Rodoviário & Campo Grande - Bataguassu & 2,66 & 52 & 373 & 0,00 & 0,00 & 0,00 & 38,20 & 38,20 & & & $36 \%$ \\
\hline 3 & Hidroviário & Batagassu - Pederneiras & 74,46 & 4.000 & 605 & 0,00 & 0,00 & 3,00 & 22,53 & 25,53 & 105,73 & $45 \%$ & $24 \%$ \\
\hline & Ferroviário & Pederneiras - Santos & 403,98 & 5.200 & 502 & 0,00 & 0,00 & 3,00 & 39,00 & 42,00 & & & $40 \%$ \\
\hline & Rodoviário & Campo Grande - Três Lagoas & 2,66 & 52 & 350 & 0,00 & 0,00 & 0,00 & 35,85 & 35,85 & & & $39 \%$ \\
\hline 3 & Hidroviário & Três Lagoas - Pederneiras & 74,46 & 4.000 & 281 & 0,00 & 0,00 & 3,00 & 10,46 & 13,46 & 91,31 & $26 \%$ & $15 \%$ \\
\hline & Ferroviário & Pederneiras - Santos & 403,98 & 5.200 & 502 & 0,00 & 0,00 & 3,00 & 39,00 & 42,00 & & & $46 \%$ \\
\hline 1 & Rodoviário & Campo Grande - Paranaguá & 2,66 & 52 & 1.160 & 0,00 & 627,17 & 0,00 & 130,87 & 130,87 & 130,87 & $80 \%$ & $100 \%$ \\
\hline & Rodoviário & Campo Grande - Cascavel & 2,66 & 52 & 683 & 0,00 & 0,00 & 0,00 & 69,95 & 69,95 & & & $60 \%$ \\
\hline 2 & Ferroviário & Cascavel - Paranaguá & 122,52 & 2.100 & 737 & 0,00 & 0,00 & 3,00 & 43,00 & 46,00 & 115,95 & $59 \%$ & $40 \%$ \\
\hline & Ferroviário & Campo Grande - Corumbá & 86,58 & 1.250 & 462 & 13,99 & 0,00 & 3,00 & 32,00 & 48,99 & & & $60 \%$ \\
\hline 7 & Hidroviário & Corumbá - Nova Palmira & 190,65 & 18.000 & 2.770 & 0,00 & 0,00 & 3,00 & 29,34 & 32,34 & 81,33 & $12 \%$ & $40 \%$ \\
\hline 2 & Rodoviário & Campo Grande - Chapadão do Sul & 2,66 & 52 & 332 & 0,00 & 0,00 & 0,00 & 34,00 & 34,00 & 12470 & & $27 \%$ \\
\hline 2 & Ferroviário & Chapadão do Sul - Santos & 519,37 & 7.000 & 1.182 & 0,00 & 0,00 & 3,00 & 87,70 & 90,70 & 124,10 & $11 \%$ & $73 \%$ \\
\hline & Rodoviário & Campo Grande - São Simão & 2,66 & 52 & 564 & 0,00 & 0,00 & 0,00 & 57,76 & 57,76 & & & $46 \%$ \\
\hline 3 & Hidroviário & São Simão - Pederneiras & 74,46 & 4.000 & 640 & 0,00 & 0,00 & 3,00 & 23,83 & 26,83 & 126,59 & $74 \%$ & $21 \%$ \\
\hline & Ferroviário & Pederneiras - Santos & 403,98 & 5.200 & 502 & 0,00 & 0,00 & 3,00 & 39,00 & 42,00 & & & $33 \%$ \\
\hline 2 & Rodoviário & Campo Grande - P. Epitácio & 2,66 & 52 & 410 & 0,00 & 0,00 & 0,00 & 41,99 & 41,99 & 9049 & $24 \%$ & $46 \%$ \\
\hline 2 & Ferroviário & P. Epitácio - Santos & 175,00 & 2.500 & 650 & 0,00 & 0,00 & 3,00 & 45,50 & 48,50 & 90,49 & $24 \%$ & $54 \%$ \\
\hline & Rodoviário & Campo Grande - Maringá & 2,66 & 52 & 636 & 0,00 & 71,40 & 0,00 & 66,51 & 66,51 & & & $61 \%$ \\
\hline 2 & Ferroviário & Maringá - Paranaguá & 128,44 & 2.100 & 654 & 0,00 & 0,00 & 3,00 & 40,00 & 43,00 & 109,51 & $51 \%$ & $39 \%$ \\
\hline 4 & Ferroviário & Campo Grande - Paranaguá & 122,52 & 2.100 & 1.270 & 8,28 & 0,00 & 3,00 & 74,10 & 85,37 & 85,37 & $17 \%$ & $100 \%$ \\
\hline
\end{tabular}


CUSTOS DE TRANSPORTE POR ITINERÁRIOS - 40\% RETORNO

TRANSPORTE DE SOJA

REGIÃO CENTRAL - POLO CAMPO GRANDE

\begin{tabular}{|c|c|c|c|c|c|c|c|c|c|c|c|c|c|}
\hline & \multirow{2}{*}{\multicolumn{3}{|c|}{ Tarifas (R\$ por Tonelada) }} & \\
\hline & & & & & & & & & & & \multirow{2}{*}{\begin{tabular}{|l} 
Custo \\
Total por
\end{tabular}} & \multirow{2}{*}{\multicolumn{2}{|c|}{\begin{tabular}{|l|l|} 
& Participação nos \\
custos
\end{tabular}}} \\
\hline Cenários & Modal (is) & Trecho(s) & Frete/Km & Peso (ton) & $\mathrm{Km}$ & Ponta Rd & Pedágio & Transbordo & Frete & Total & & & \\
\hline 1 & Rodoviário & Campo Grande - Santos & 2,66 & 52 & 1.155 & 0,00 & 679,14 & 0,00 & 107,70 & 107,70 & 107,70 & $70 \%$ & $100 \%$ \\
\hline 4 & Ferroviário & Campo Grande - Santos & 172,66 & 2.500 & 1.306 & 13,99 & 0,00 & 3,00 & 90,20 & 107,19 & 107,19 & $69 \%$ & $100 \%$ \\
\hline \multirow[b]{2}{*}{6} & Rodoviário & Campo Grande - Pto Murtinho & 2,66 & 52 & 450 & 0,00 & 0,00 & 0,00 & 36,87 & 36,87 & \multirow[b]{2}{*}{63,51} & \multirow[b]{2}{*}{$0 \%$} & $58 \%$ \\
\hline & Hidroviário & Pto Murtinho - Nova Palmira & 190,65 & 18.000 & 2.232 & 0,00 & 0,00 & 3,00 & 23,64 & 26,64 & & & $42 \%$ \\
\hline \multirow{3}{*}{3} & Rodoviário & Campo Grande - Bataguassu & 2,66 & 52 & 373 & 0,00 & 0,00 & 0,00 & 30,56 & 30,56 & \multirow{3}{*}{98,09} & \multirow{3}{*}{$54 \%$} & $31 \%$ \\
\hline & Hidroviário & Batagassu - Pederneiras & 74,46 & 4.000 & 605 & 0,00 & 0,00 & 3,00 & 22,53 & 25,53 & & & $26 \%$ \\
\hline & Ferroviário & Pederneiras - Santos & 403,98 & 5.200 & 502 & 0,00 & 0,00 & 3,00 & 39,00 & 42,00 & & & $43 \%$ \\
\hline \multirow{3}{*}{3} & Rodoviário & Campo Grande - Três Lagoas & 2,66 & 52 & 350 & 0,00 & 0,00 & 0,00 & 28,68 & 28,68 & \multirow{3}{*}{84,14} & \multirow{3}{*}{$32 \%$} & $34 \%$ \\
\hline & Hidroviário & Três Lagoas - Pederneiras & 74,46 & 4.000 & 281 & 0,00 & 0,00 & 3,00 & 10,46 & 13,46 & & & $16 \%$ \\
\hline & Ferroviário & Pederneiras - Santos & 403,98 & 5.200 & 502 & 0,00 & 0,00 & 3,00 & 39,00 & 42,00 & & & $50 \%$ \\
\hline 1 & Rodoviário & Campo Grande - Paranaguá & 2,66 & 52 & 1.160 & 0,00 & 517,73 & 0,00 & 105,00 & 105,00 & 105,00 & $65 \%$ & $100 \%$ \\
\hline \multirow[b]{2}{*}{2} & Rodoviário & Campo Grande - Cascavel & 2,66 & 52 & 640 & 0,00 & 0,00 & 0,00 & 52,44 & 52,44 & \multirow{2}{*}{98,44} & \multirow[b]{2}{*}{$55 \%$} & $53 \%$ \\
\hline & Ferroviário & Cascavel - Paranaguá & 122,52 & 2.100 & 737 & 0,00 & 0,00 & 3,00 & 43,00 & 46,00 & & & $47 \%$ \\
\hline \multirow[b]{2}{*}{7} & Ferroviário & Campo Grande - Corumbá & 86,58 & 1.250 & 462 & 13,99 & 0,00 & 3,00 & 32,00 & 48,99 & \multirow[b]{2}{*}{81,33} & \multirow[b]{2}{*}{$28 \%$} & $60 \%$ \\
\hline & Hidroviário & Corumbá - Nova Palmira & 190,65 & 18.000 & 2.770 & 0,00 & 0,00 & 3,00 & 29,34 & 32,34 & & & $40 \%$ \\
\hline \multirow{2}{*}{2} & Rodoviário & Campo Grande - Chapadão do Sul & 2,66 & 52 & 332 & 0,00 & 0,00 & 0,00 & 27,20 & 27,20 & \multirow{2}{*}{117,90} & \multirow{2}{*}{$86 \%$} & $23 \%$ \\
\hline & Ferroviário & Chapadão do Sul - Santos & 519,37 & 7.000 & 1.182 & 0,00 & 0,00 & 3,00 & 87,70 & 90,70 & & & $77 \%$ \\
\hline \multirow{3}{*}{3} & Rodoviário & Campo Grande - São Simão & 2,66 & 52 & 350 & 0,00 & 0,00 & 0,00 & 28,68 & 28,68 & \multirow{3}{*}{97,51} & \multirow{3}{*}{$54 \%$} & $29 \%$ \\
\hline & Hidroviário & São Simão - Pederneiras & 74,46 & 4.000 & 640 & 0,00 & 0,00 & 3,00 & 23,83 & 26,83 & & & $28 \%$ \\
\hline & Ferroviário & Pederneiras - Santos & 403,98 & 5.200 & 502 & 0,00 & 0,00 & 3,00 & 39,00 & 42,00 & & & $43 \%$ \\
\hline \multirow[b]{2}{*}{2} & Rodoviário & Campo Grande - P. Epitácio & 2,66 & 52 & 410 & 0,00 & 0,00 & 0,00 & 33,59 & 33,59 & \multirow[b]{2}{*}{2,09} & & $41 \%$ \\
\hline & Ferroviário & P. Epitácio - Santos & 175,00 & 2.500 & 650 & 0,00 & 0,00 & 3,00 & 45,50 & 48,50 & & $29 \%$ & $59 \%$ \\
\hline 2 & Rodoviário & Campo Grande - Maringá & 2,66 & 52 & 636 & 0,00 & 71,40 & 0,00 & 53,48 & 53,48 & & $52 \%$ & $55 \%$ \\
\hline 2 & Ferroviário & Maringá - Paranaguá & 128,44 & 2.100 & 654 & 0,00 & 0,00 & 3,00 & 40,00 & 43,00 & 96,48 & $52 \%$ & $45 \%$ \\
\hline$\overline{4}$ & Ferroviário & Campo Grande - Paranaguá & 122,52 & 2.100 & 1.270 & 8,28 & 0,00 & 3,00 & 74,10 & 85,37 & 85,37 & $34 \%$ & $100 \%$ \\
\hline
\end{tabular}




\section{CUSTOS DE TRANSPORTE POR ITINERÁRIOS - 60\% RETORNO}

\section{TRANSPORTE DE SOJA}

REGIÃO CENTRAL - POLO CAMPO GRANDE

\begin{tabular}{|c|c|c|c|c|c|c|c|c|c|c|c|c|c|}
\hline \multicolumn{8}{|c|}{ REGIÃO CENTRAL - POLO CAMPO GRANDE } & & & & \multicolumn{3}{|c|}{ Bitrem 9 eixos } \\
\hline & & & & & & & & Tarifas $(R \$)$ & or Tonel & & Custo Total por & & Participação \\
\hline Cenários & Modal (is) & Trecho(s) & Frete/Km & Peso (ton) & Km & Ponta Rd & Pedágio & Transbordo & Frete & Total & tonelada & $\%$ & nos custos \\
\hline 1 & Rodoviário & Campo Grande - Santos & 2,66 & 52 & 1.155 & 0,00 & 579,60 & 0,00 & 93,95 & 93,95 & 93,95 & $60 \%$ & $100 \%$ \\
\hline 4 & Ferroviário & Campo Grande - Santos & 172,66 & 2.500 & 1.306 & 13,99 & 0,00 & 3,00 & 90,20 & 107,19 & 107,19 & $82 \%$ & $100 \%$ \\
\hline 6 & Rodoviário & Campo Grande - Pto Murtinho & 2,66 & 52 & 450 & 0,00 & 0,00 & 0,00 & 32,26 & 32,26 & & & $55 \%$ \\
\hline 6 & Hidroviário & Pto Murtinho - Nova Palmira & 190,65 & 18.000 & 2.232 & 0,00 & 0,00 & 3,00 & 23,64 & 26,64 & 58,90 & $0 \%$ & $45 \%$ \\
\hline & Rodoviário & Campo Grande - Bataguassu & 2,66 & 52 & 373 & 0,00 & 0,00 & 0,00 & 26,74 & 26,74 & & & $28 \%$ \\
\hline 3 & Hidroviário & Batagassu - Pederneiras & 74,46 & 4.000 & 605 & 0,00 & 0,00 & 3,00 & 22,53 & 25,53 & 94,27 & $60 \%$ & $27 \%$ \\
\hline & Ferroviário & Pederneiras - Santos & 403,98 & 5.200 & 502 & 0,00 & 0,00 & 3,00 & 39,00 & 42,00 & & & $45 \%$ \\
\hline & Rodoviário & Campo Grande - Três Lagoas & 2,66 & 52 & 350 & 0,00 & 0,00 & 0,00 & 25,09 & 25,09 & & & $31 \%$ \\
\hline 3 & Hidroviário & Três Lagoas - Pederneiras & 74,46 & 4.000 & 281 & 0,00 & 0,00 & 3,00 & 10,46 & 13,46 & 80,55 & $37 \%$ & $17 \%$ \\
\hline & Ferroviário & Pederneiras - Santos & 403,98 & 5.200 & 502 & 0,00 & 0,00 & 3,00 & 39,00 & 42,00 & & & $52 \%$ \\
\hline 1 & Rodoviário & Campo Grande - Paranaguá & 2,66 & 52 & 1.160 & 0,00 & 495,00 & 0,00 & 92,68 & 92,68 & 92,68 & $57 \%$ & $100 \%$ \\
\hline & Rodoviário & Campo Grande - Cascavel & 2,66 & 52 & 683 & 0,00 & 0,00 & 0,00 & 48,97 & 48,97 & & & $52 \%$ \\
\hline 2 & Ferroviário & Cascavel - Paranaguá & 122,52 & 2.100 & 737 & 0,00 & 0,00 & 3,00 & 43,00 & 46,00 & 94,97 & $61 \%$ & $48 \%$ \\
\hline & Ferroviário & Campo Grande - Corumbá & 86,58 & 1.250 & 462 & 13,99 & 0,00 & 3,00 & 32,00 & 48,99 & & & $60 \%$ \\
\hline 7 & Hidroviário & Corumbá - Nova Palmira & 190,65 & 18.000 & 2.770 & 0,00 & 0,00 & 3,00 & 29,34 & 32,34 & 81,33 & $38 \%$ & $40 \%$ \\
\hline 2 & Rodoviário & Campo Grande - Chapadão do Sul & 2,66 & 52 & 332 & 0,00 & 0,00 & 0,00 & 23,80 & 23,80 & 1450 & 940\% & $21 \%$ \\
\hline 2 & Ferroviário & Chapadão do Sul - Santos & 519,37 & 7.000 & 1.182 & 0,00 & 0,00 & 3,00 & 87,70 & 90,70 & 114,50 & $94 \%$ & $79 \%$ \\
\hline & Rodoviário & Campo Grande - São Simão & 2,66 & 52 & 564 & 0,00 & 0,00 & 0,00 & 40,44 & 40,44 & & & $34 \%$ \\
\hline 3 & Hidroviário & São Simão - Pederneiras & 74,46 & 3.000 & 640 & 0,00 & 0,00 & 3,00 & 31,77 & 34,77 & 117,21 & $99 \%$ & $30 \%$ \\
\hline & Ferroviário & Pederneiras - Santos & 403,98 & 5.200 & 502 & 0,00 & 0,00 & 3,00 & 39,00 & 42,00 & & & $36 \%$ \\
\hline & Rodoviário & Campo Grande - P. Epitácio & 2,66 & 52 & 410 & 0,00 & 0,00 & 0,00 & 29,39 & 29,39 & & & $38 \%$ \\
\hline 2 & Ferroviário & P. Epitácio - Santos & 175,00 & 2.500 & 650 & 0,00 & 0,00 & 3,00 & 45,50 & 48,50 & 77,89 & $32 \%$ & $62 \%$ \\
\hline 2 & Rodoviário & Campo Grande - Maringá & 2,66 & 52 & 636 & 0,00 & 71,40 & 0,00 & 46,97 & 46,97 & 8097 & $530 \%$ & $52 \%$ \\
\hline 2 & Ferroviário & Maringá - Paranaguá & 128,44 & 2.100 & 654 & 0,00 & 0,00 & 3,00 & 40,00 & 43,00 & 89,97 & $53 \%$ & $48 \%$ \\
\hline$\overline{4}$ & Ferroviário & Campo Grande - Paranaguá & 122,52 & 2.100 & 1.270 & 8,28 & 0,00 & 3,00 & 74,10 & 85,37 & 85,37 & $45 \%$ & $100 \%$ \\
\hline
\end{tabular}




\section{APÊNDICE K - Custos para o Pólo de Dourados com bitrem de 9 eixos}

\section{CUSTOS DE TRANSPORTE POR ITINERÁRIOS - 0\% RETORNO}

\section{TRANSPORTE DE SOJA}

REGIÃO SUL - POLO DOURADOS

\begin{tabular}{|c|c|c|c|c|c|c|c|c|c|c|c|c|c|}
\hline \multicolumn{8}{|c|}{ REGIÃO SUL - POLO DOURADOS } & & & & \multicolumn{3}{|c|}{ Bitrem 9 eixos } \\
\hline & & & & & & & & Tarifas $(R S$ & or Tonela & & Custo Total por & & Participação nos \\
\hline Cenários & Modal (is) & $\operatorname{Trecho}(\mathrm{s})$ & Frete/Km & Peso (ton) & Km & Ponta Rd & Pedágio & Transbordo & Frete & Total & tonelada & $\%$ & custos \\
\hline 1 & Rodoviário & Dourados - Santos & 2,66 & 52 & 1.145 & 0,00 & 887,40 & 0,00 & 134,34 & 134,34 & 134,34 & $99 \%$ & $100 \%$ \\
\hline 4 & Ferroviário & Dourados - Santos & 89,78 & 1.300 & 1.482 & 13,16 & 0,00 & 3,00 & 102,35 & 118,51 & 118,51 & $75 \%$ & $100 \%$ \\
\hline & Rodoviário & Dourados - Pto Murtinho & 2,66 & 52 & 400 & 0,00 & 0,00 & 0,00 & 40,97 & 40,97 & & & $61 \%$ \\
\hline 6 & Hidroviário & Pto Murtinho - Nova Palmira & 190,65 & 18.000 & 2.232 & 0,00 & 0,00 & 3,00 & 23,64 & 26,64 & 67,61 & $0 \%$ & $39 \%$ \\
\hline & Rodoviário & Dourados - Bataguassu & 2,66 & 52 & 330 & 0,00 & 0,00 & 0,00 & 33,80 & 33,80 & & & $33 \%$ \\
\hline 3 & Hidroviário & Batagassu - Pederneiras & 74,46 & 4.000 & 605 & 0,00 & 0,00 & 3,00 & 22,53 & 25,53 & 101,32 & $50 \%$ & $25 \%$ \\
\hline & Ferroviário & Pederneiras - Santos & 403,98 & 5.200 & 502 & 0,00 & 0,00 & 3,00 & 39,00 & 42,00 & & & $41 \%$ \\
\hline 1 & Rodoviário & Dourados - Paranaguá & 2,66 & 52 & 940 & 0,00 & 232,20 & 0,00 & 100,74 & 100,74 & 100,74 & $49 \%$ & $100 \%$ \\
\hline & Rodoviário & Dourados - Cascavel & 2,66 & 52 & 430 & 0,00 & 0,00 & 0,00 & 44,04 & 44,04 & & & $49 \%$ \\
\hline 2 & Ferroviário & Cascavel - Paranaguá & 122,52 & 2.100 & 737 & 0,00 & 0,00 & 3,00 & 43,00 & 46,00 & 90,04 & $33 \%$ & $51 \%$ \\
\hline & Rodoviário & Dourados - Corumbá & 2,66 & 52 & 626 & 0,00 & 40,00 & 0,00 & 64,88 & 64,88 & & & $67 \%$ \\
\hline 6 & Hidroviário & Corumbá - Nova Palmira & 190,65 & 18.000 & 2.770 & 0,00 & 0,00 & 3,00 & 29,34 & 32,34 & 97,22 & $44 \%$ & $33 \%$ \\
\hline 2 & Rodoviário & Dourados - Chapadão do Sul & 2,66 & 52 & 552 & 0,00 & 0,00 & 0,00 & 56,54 & 56,54 & 147.24 & $118 \%$ & $38 \%$ \\
\hline 2 & Ferroviário & Chapadão do Sul - Santos & 519,37 & 7.000 & 1.182 & 0,00 & 0,00 & 3,00 & 87,70 & 90,70 & $14 r, 24$ & $118 \%$ & $62 \%$ \\
\hline & Rodoviário & Dourados - P. Epitácio & 2,66 & 52 & 379 & 0,00 & 0,00 & 0,00 & $\begin{array}{ll}38,82 \\
\end{array}$ & 38,82 & & & $44 \%$ \\
\hline 2 & Ferroviário & P. Epitácio - Santos & 175,00 & 2.500 & 650 & 0,00 & 0,00 & 3,00 & 45,50 & 48,50 & 87,32 & $29 \%$ & $56 \%$ \\
\hline & Rodoviário & Dourados - Maringá & 2,66 & 52 & 500 & 0,00 & 71,40 & 0,00 & 52,58 & 52,58 & & & $55 \%$ \\
\hline 2 & Ferroviário & Maringá - Paranaguá & 128,44 & 2.100 & 654 & 0,00 & 0,00 & 3,00 & 40,00 & 43,00 & 95,58 & $41 \%$ & $45 \%$ \\
\hline 4 & Ferroviário & Dourados - Paranaguá & 122,52 & 2.100 & 1.087 & 13,16 & 0,00 & 3,00 & \begin{tabular}{|c|}
63,42 \\
\end{tabular} & 79,58 & 79,58 & $18 \%$ & $100 \%$ \\
\hline
\end{tabular}


CUSTOS DE TRANSPORTE POR ITINERÁRIOS - 40\% RETORNO

TRANSPORTE DE SOJA

REGIÃO SUL - POLO DOURADOS

\begin{tabular}{|c|c|c|c|c|c|c|c|c|c|c|c|c|c|}
\hline \multicolumn{8}{|c|}{ REGIÃO SUL - POLO DOURADOS } & \multirow{2}{*}{\multicolumn{3}{|c|}{ Tarifas (R\$ por Tonelada) }} & \\
\hline & & & & & & & & & & & \multicolumn{3}{|c|}{$\begin{array}{l}\text { Bitrem } 9 \text { eixos } \\
\text { |Participação nos }\end{array}$} \\
\hline Cenários & Modal (is) & Trecho(s) & Frete/Km & Peso (ton) & $K m$ & Ponta Rd & Pedágio & Transbordo & Frete & Total & Total por & $\%$ & custos \\
\hline 1 & Rodoviário & Dourados - Santos & 2,66 & 52 & 1.126 & 0,00 & 730,80 & 0,00 & 106,31 & 106,31 & 106,31 & $79 \%$ & $100 \%$ \\
\hline 4 & Ferroviário & Dourados - Santos & 89,78 & 1.300 & 1.482 & 13,16 & 0,00 & 3,00 & 102,35 & 118,51 & 118,51 & $99 \%$ & $100 \%$ \\
\hline & Rodoviário & Dourados - Pto Murtinho & 2,66 & 52 & 400 & 0,00 & 0,00 & 0,00 & 32,77 & 32,77 & & & $55 \%$ \\
\hline 6 & Hidroviário & Pto Murtinho - Nova Palmira & 190,65 & 18.000 & 2.232 & 0,00 & 0,00 & 3,00 & 23,64 & 26,64 & 59,42 & $0 \%$ & $45 \%$ \\
\hline & Rodoviário & Dourados - Bataguassu & 2,66 & 52 & 330 & 0,00 & 0,00 & 0,00 & 27,04 & 27,04 & & & $29 \%$ \\
\hline 3 & Hidroviário & Batagassu - Pederneiras & 74,46 & 4.000 & 605 & 0,00 & 0,00 & 3,00 & 22,53 & 25,53 & 94,56 & $59 \%$ & $27 \%$ \\
\hline & Ferroviário & Pederneiras - Santos & 403,98 & 5.200 & 502 & 0,00 & 0,00 & 3,00 & 39,00 & 42,00 & & & $44 \%$ \\
\hline 1 & Rodoviário & Dourados - Paranaguá & 2,66 & 52 & 940 & 0,00 & 185,76 & 0,00 & 80,59 & 80,59 & 80,59 & $36 \%$ & $100 \%$ \\
\hline & Rodoviário & Dourados - Cascavel & 2,66 & 52 & 430 & 0,00 & 0,00 & 0,00 & 35,23 & 35,23 & & & $43 \%$ \\
\hline 2 & Ferroviário & Cascavel - Paranaguá & 122,52 & 2.100 & 737 & 0,00 & 0,00 & 3,00 & 43,00 & 46,00 & 81,23 & $3 / \%$ & $57 \%$ \\
\hline & Rodoviário & Dourados - Corumbá & 2,66 & 52 & 626 & 0,00 & 32,00 & 0,00 & 51,91 & 51,91 & & & $62 \%$ \\
\hline 6 & Hidroviário & Corumbá - Nova Palmira & 190,65 & 18.000 & 2.770 & 0,00 & 0,00 & 3,00 & 29,34 & 32,34 & 84,25 & $42 \%$ & $38 \%$ \\
\hline 2 & Rodoviário & Dourados - Chapadão do Sul & 2,66 & 52 & 552 & 0,00 & 0,00 & 0,00 & 45,23 & 45,23 & 135.93 & $129 \%$ & $33 \%$ \\
\hline 2 & Ferroviário & Chapadão do Sul - Santos & 519,37 & 7.000 & 1.182 & 0,00 & 0,00 & 3,00 & 87,70 & 90,70 & 135,93 & $129 \%$ & $67 \%$ \\
\hline 2 & Rodoviário & Dourados - P. Epitácio & 2,66 & 52 & 379 & 0,00 & 0,00 & 0,00 & 31,05 & 31,05 & 955 & $34 \%$ & $39 \%$ \\
\hline 2 & Ferroviário & P. Epitácio - Santos & 175,00 & 2.500 & 650 & 0,00 & 0,00 & 3,00 & 45,50 & 48,50 & 19,55 & $34 \%$ & $61 \%$ \\
\hline 2 & Rodoviário & Dourados - Maringá & 2,66 & 52 & 500 & 0,00 & 71,40 & 0,00 & 42,34 & 42,34 & 8534 & $44 \%$ & $50 \%$ \\
\hline 2 & Ferroviário & Maringá - Paranaguá & 128,44 & 2.100 & 654 & 0,00 & 0,00 & 3,00 & 40,00 & 43,00 & 85,34 & $44 \%$ & $50 \%$ \\
\hline 4 & Ferroviário & Dourados - Paranaguá & 122,52 & 2.100 & 1.087 & 13,16 & 0,00 & 3,00 & 63,42 & 79,58 & 79,58 & $34 \%$ & $100 \%$ \\
\hline
\end{tabular}




\section{CUSTOS DE TRANSPORTE POR ITINERÁRIOS - 60\% RETORNO}

\section{TRANSPORTE DE SOJA}

REGIĀO REGIĀO SUL - POLO DOURADOS

\begin{tabular}{|c|c|c|c|c|c|c|c|c|c|c|c|c|c|}
\hline \multicolumn{8}{|c|}{ REGIÄO REGIÄO SUL - POLO DOURADOS } & & & & \multicolumn{3}{|c|}{ Bitrem 9 eixos } \\
\hline & & & & & & & & Tarifas $(R S$ & or Tonel & & Custo Total por & & Participação \\
\hline Cenários & Modal (is) & Trecho(s) & Frete/Km & Peso (ton) & Km & Ponta Rd & Pedágio & Transbordo & Frete & Total & tonelada & $\%$ & nos custos \\
\hline 1 & Rodoviário & Dourados - Santos & 2,66 & 52 & 1.145 & 0,00 & 565,69 & 0,00 & 92,97 & 92,97 & 92,97 & $68 \%$ & $100 \%$ \\
\hline 4 & Ferroviário & Dourados - Santos & 89,78 & 1.300 & 1.482 & 13,16 & 0,00 & 3,00 & 102,35 & 118,51 & 118,51 & $114 \%$ & $100 \%$ \\
\hline & Rodoviário & Dourados - Pto Murtinho & 2,66 & 52 & 400 & 0,00 & 0,00 & 0,00 & 28,68 & 28,68 & & & $52 \%$ \\
\hline 6 & Hidroviário & Pto Murtinho - Nova Palmira & 190,65 & 18.000 & 2.232 & 0,00 & 0,00 & 3,00 & 23,64 & 26,64 & 55,32 & $0 \%$ & $48 \%$ \\
\hline & Rodoviário & Dourados - Bataguassu & 2,66 & 52 & 330 & 0,00 & 0,00 & 0,00 & 23,66 & 23,66 & & & $26 \%$ \\
\hline 3 & Hidroviário & Batagassu - Pederneiras & 74,46 & 4.000 & 605 & 0,00 & 0,00 & 3,00 & 22,53 & 25,53 & 91,18 & $65 \%$ & $28 \%$ \\
\hline & Ferroviário & Pederneiras - Santos & 403,98 & 5.200 & 502 & 0,00 & 0,00 & 3,00 & 39,00 & 42,00 & & & $46 \%$ \\
\hline 1 & Rodoviário & Dourados - Paranaguá & 2,66 & 52 & 940 & 0,00 & 162,54 & 0,00 & 70,52 & 70,52 & 70,52 & $27 \%$ & $100 \%$ \\
\hline & Rodoviário & Dourados - Cascavel & 2,66 & 52 & 430 & 0,00 & 0,00 & 0,00 & 30,83 & 30,83 & & & $40 \%$ \\
\hline 2 & Ferroviário & Cascavel - Paranaguá & 122,52 & 2.100 & 737 & 0,00 & 0,00 & 3,00 & 43,00 & 46,00 & 76,83 & $39 \%$ & $60 \%$ \\
\hline 6 & Rodoviário & Dourados - Corumbá & 2,66 & 52 & 626 & 0,00 & 28,00 & 0,00 & 45,42 & 45,42 & & & $58 \%$ \\
\hline 6 & Hidroviário & Corumbá - Nova Palmira & 190,65 & 18.000 & 2.770 & 0,00 & 0,00 & 3,00 & 29,34 & 32,34 & 77,76 & $41 \%$ & $42 \%$ \\
\hline & Rodoviário & Dourados - Chapadão do Sul & 2,66 & 52 & 552 & 0,00 & 0,00 & 0,00 & 39,57 & 39,57 & 13027 & 1250 & $30 \%$ \\
\hline 2 & Ferroviário & Chapadão do Sul - Santos & 519,37 & 7.000 & 1.182 & 0,00 & 0,00 & 3,00 & 87,70 & 90,70 & 130,21 & $135 \%$ & $70 \%$ \\
\hline & Rodoviário & Dourados - P. Epitácio & 2,66 & 52 & 379 & 0,00 & 0,00 & 0,00 & 27,17 & 27,17 & & & $36 \%$ \\
\hline 2 & Ferroviário & P. Epitácio - Santos & 175,00 & 2.500 & 650 & 0,00 & 0,00 & 3,00 & 45,50 & 48,50 & 75,67 & $37 \%$ & $64 \%$ \\
\hline 2 & Rodoviário & Dourados - Maringá & 2,66 & 52 & 500 & 0,00 & 71,40 & 0,00 & 37,22 & 37,22 & 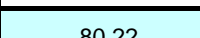 & $15 \%$ & $46 \%$ \\
\hline 2 & Ferroviário & Maringá - Paranaguá & 128,44 & 2.100 & 654 & 0,00 & 0,00 & 3,00 & 40,00 & 43,00 & 80,22 & $45 \%$ & $54 \%$ \\
\hline 4 & Ferroviário & Dourados - Paranaguá & 122,52 & 2.100 & 1.087 & 13,16 & 0,00 & 3,00 & 63,42 & 79,58 & 79,58 & $44 \%$ & $100 \%$ \\
\hline
\end{tabular}


APÊNDICE $L$ - Custos para o Pólo de Corumbá com bitrem de 9 eixos

CUSTOS DE TRANSPORTE POR ITINERÁRIOS - O\% RETORNO

TRANSPORTE DE MINÉRIOS DE FERRO E MANGANÊS

POLO CORUMBÁ

\begin{tabular}{|c|c|c|c|c|c|c|c|c|c|c|c|c|c|}
\hline \multicolumn{8}{|l|}{$r$} & \multirow{2}{*}{\multicolumn{3}{|c|}{ Tarifas (R\$ por Tonelada) }} & \multicolumn{3}{|c|}{ Bitrem 9 eixos } \\
\hline & & & & & & & & & & & Custo Total por & & Participação nos \\
\hline Cenários & Modal (is) & Trecho (s) & Frete $/ K m$ & Peso (ton) & $K m$ & Ponta Rd & Pedágio & Transbordo & Frete & Total & & $\%$ & custos \\
\hline 1 & Rodoviário & Corumbá - Santos & 2,66 & 52 & 1.572 & 0,00 & 875,83 & 0,00 & 177,85 & 177,85 & 177,85 & $396 \%$ & $100 \%$ \\
\hline 4 & Ferroviário & Corumbá - Santos & 66,46 & 1.250 & 1.768 & 3,55 & 0,00 & 3,00 & 94,00 & 100,55 & 100,55 & $180 \%$ & $100 \%$ \\
\hline 8 & Hidroviário & Corumbá - Nova Palmira & 190,65 & 18.000 & 2.770 & 3,55 & 0,00 & 3,00 & 29,34 & 35,89 & 35,89 & $0 \%$ & $100 \%$ \\
\hline 1 & Rodoviário & Corumbá - Paranaguá & 2,66 & 52 & 1.517 & 0,00 & 598,63 & 0,00 & 166,88 & 166,88 & 166,88 & $365 \%$ & $100 \%$ \\
\hline & Rodoviário & Corumbá - Cascavel & 2,66 & 52 & 1041 & 0,00 & 40,00 & 0,00 & 107,39 & 107,39 & & & $70 \%$ \\
\hline 2 & Ferroviário & Cascavel - Paranaguá & 122,52 & 2.100 & 737 & 0,00 & 0,00 & 3,00 & 43,00 & 46,00 & 153,39 & $327 \%$ & $30 \%$ \\
\hline 4 & $\begin{array}{l}\text { Ferroviário } \\
\end{array}$ & Corumbá - Paranaguá & 122,52 & 2.100 & 1.680 & 3,55 & 0,00 & 3,00 & 98,02 & 104,57 & 104,57 & $191 \%$ & $100 \%$ \\
\hline
\end{tabular}

CUSTOS DE TRANSPORTE POR ITINERÁRIOS - 40\% RETORNO

TRANSPORTE DE MINÉRIOS DE FERRO E MANGANÊS

POLO CORUMBÁ

\begin{tabular}{|c|c|c|c|c|c|c|c|c|c|c|c|c|c|}
\hline \multicolumn{8}{|c|}{ POLO CORUMBA } & \multirow{2}{*}{\multicolumn{3}{|c|}{ Tarifas $(R S$ por Tonelada) }} & \multicolumn{3}{|c|}{ Bitrem 9 eixos } \\
\hline & & & & & & & & & & & Custo & & |Participação nos \\
\hline Cenários & Modal (is) & Trecho (s) & Frete/Km & Peso (ton) & Km & Ponta Rd & Pedágio & Transbordo & Frete & Total & Total por & $\%$ & custos \\
\hline 1 & Rodoviário & Corumbá - Santos & 2,66 & 52 & 1.572 & 0,00 & 700,66 & 0,00 & 142,28 & 142,28 & 142,28 & $296 \%$ & $100 \%$ \\
\hline 4 & \begin{tabular}{|l|} 
Ferroviário \\
\end{tabular} & Corumbá - Santos & 66,46 & 1.250 & 1.768 & 3,55 & 0,00 & 3,00 & 94,00 & 100,55 & 100,55 & $180 \%$ & $100 \%$ \\
\hline 8 & Hidroviário & Corumbá - Nova Palmira & 190,65 & 18.000 & 2.770 & 3,55 & 0,00 & 3,00 & 29,34 & 35,89 & 35,89 & $0 \%$ & $100 \%$ \\
\hline 1 & Rodoviário & Corumbá - Paranaguá & 2,66 & 52 & 1.517 & 0,00 & 478,90 & 0,00 & 133,51 & 133,51 & 133,51 & $272 \%$ & $100 \%$ \\
\hline 2 & Rodoviário & Corumbá- Cascavel & 2,66 & 52 & 1041 & 0,00 & 32,00 & 0,00 & 85,91 & 85,91 & & & $65 \%$ \\
\hline 2 & Ferroviário & Cascavel - Paranaguá & 122,52 & 2.100 & 737 & 0,00 & 0,00 & 3,00 & 43,00 & 46,00 & 131,91 & $268 \%$ & $35 \%$ \\
\hline 4 & Ferroviário & Corumbá - Paranaguá & 122,52 & 2.100 & 1.680 & 3,55 & 0,00 & 3,00 & 98,02 & 104,57 & 104,57 & $191 \%$ & $100 \%$ \\
\hline
\end{tabular}




\section{CUSTOS DE TRANSPORTE POR ITINERÁRIOS - 60\% RETORNO}

TRANSPORTE DE MINÉRIOS DE FERRO E MANGANÊS

POLO CIPOLO CORUMBÁ

\begin{tabular}{|c|c|c|c|c|c|c|c|c|c|c|c|c|c|}
\hline \multicolumn{8}{|c|}{ POLO CIPOLO CORUMBÁ } & & & & \multicolumn{3}{|c|}{ Bitrem 9 eixos } \\
\hline & & & & & & & & Tarifas $(R \$)$ & or Tonel & & Custo Total por & & Participação \\
\hline Cenários & Modal (is) & Trecho(s) & Frete/Km & Peso (ton) & Km & Ponta Rd & Pedágio & Transbordo & Frete & Total & tonelada & $\%$ & nos custos \\
\hline 1 & Rodoviário & Corumbá-Santos & 2,66 & 52 & 1.572 & 0,00 & 613,08 & 0,00 & 124,49 & 124,49 & 124,49 & $247 \%$ & $100 \%$ \\
\hline 4 & Ferroviário & Corumbá - Santos & 66,46 & 1.250 & 1.768 & 3,55 & 0,00 & 3,00 & 94,00 & 100,55 & 100,55 & $180 \%$ & $100 \%$ \\
\hline 8 & Hidroviário & Corumbá - Nova Palmira & 190,65 & 18.000 & 2.770 & 3,55 & 0,00 & 3,00 & 29,34 & 35,89 & 35,89 & $0 \%$ & $100 \%$ \\
\hline 1 & Rodoviário & Corumbá - Paranaguá & 2,66 & 52 & 1.517 & 0,00 & 419,04 & 0,00 & 116,82 & 116,82 & 116,82 & $225 \%$ & $100 \%$ \\
\hline 2 & Rodoviário & Corumbá- Cascavel & 2,66 & 52 & 1041 & 0,00 & 28,00 & 0,00 & 75,17 & 75,17 & & $238 \%$ & $62 \%$ \\
\hline 2 & Ferroviário & Cascavel - Paranaguá & 122,52 & 2.100 & 737 & 0,00 & 0,00 & 3,00 & 43,00 & 46,00 & 121,17 & & $38 \%$ \\
\hline 4 & Ferroviário & Corumbá - Paranaguá & 122,52 & 2.100 & 1.680 & 3,55 & 0,00 & 3,00 & 98,02 & 104,57 & 104,57 & $191 \%$ & $100 \%$ \\
\hline
\end{tabular}

